\begin{tabular}{l} 
2. To: (Receiving Organization) \\
Distribution \\
\hline 5. Proj./Prog./Dept./Div.: \\
Spent Nuclear Fuel Project \\
8. Originator Remarks: \\
For Approval and Release
\end{tabular}

11. Receiver Remarks:
3. From: (Originating Organization)

NHC Sludge Treatment Project

6. Design Authority/Design Agent/Cog. Engr.:

A. G. Westra

\begin{tabular}{|c|c|c|c|}
\hline \multicolumn{4}{|c|}{$\begin{array}{l}\text { 4. Related EDT No.: } \\
\text { N/A }\end{array}$} \\
\hline \multicolumn{4}{|l|}{$N / A$} \\
\hline \multicolumn{4}{|c|}{$\begin{array}{l}\text { 9. Equip./Component No: } \\
\text { N/A }\end{array}$} \\
\hline \multicolumn{4}{|c|}{$\begin{array}{l}\text { 10. System/B/dg./Facility: } \\
N / A\end{array}$} \\
\hline \multicolumn{4}{|c|}{$\begin{array}{l}\text { 12. Major Assm. Dwg. No.: } \\
\text { N/A }\end{array}$} \\
\hline \multicolumn{4}{|c|}{$\begin{array}{l}\text { 13. Permit/Permit Application No.: } \\
N / A\end{array}$} \\
\hline \multicolumn{4}{|c|}{$\begin{array}{l}\text { 14. Required Response Date: } \\
\text { N/A }\end{array}$} \\
\hline$(F)$ & (G) & (H) & (I) \\
\hline $\begin{array}{l}\text { Approval } \\
\text { Desig- } \\
\text { nator }\end{array}$ & $\begin{array}{c}\text { Reason } \\
\text { for Trans- } \\
\text { mittal }\end{array}$ & $\begin{array}{c}\text { Origi- } \\
\text { nator } \\
\text { Dispo- } \\
\text { stion }\end{array}$ & $\begin{array}{c}\text { Receiv- } \\
\text { er } \\
\text { Dispo- } \\
\text { sition }\end{array}$ \\
\hline $\mathrm{N} / \mathrm{A}$ & 2 & & 1 \\
\hline & & & \\
\hline & & & \\
\hline & & & \\
\hline & & & \\
\hline & & & \\
\hline & & & \\
\hline
\end{tabular}

16.

DATA TRANSMITTED

15.

\begin{tabular}{|l|l|l}
\hline $\begin{array}{c}\text { (C) Sheet } \\
\text { No. }\end{array}$ & $\begin{array}{c}\text { (D) Rev. } \\
\text { No. }\end{array}$ & (E) Title or Description of Data Transmitted \\
\hline all & 0 & K Basin Sludge Treatment \\
\hline & & Project Chemical \\
\hline & & Processing Baseline \\
\hline & Time Diagram Study \\
\hline
\end{tabular}

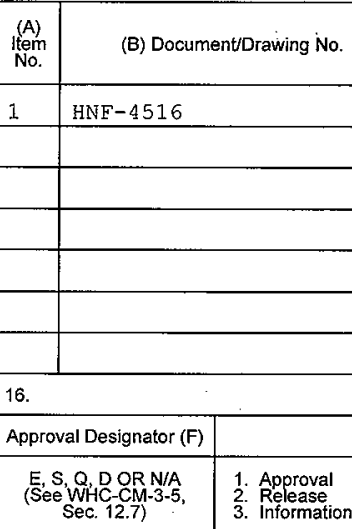

17.

Reason for Transmittal (G)

KEY

4. Review

5. Post-Review

6. Dist. (Receipt Acknow. Required)
No
SIGNATURE/DISTRIBUTION

(See Approval Designator for required signatures)

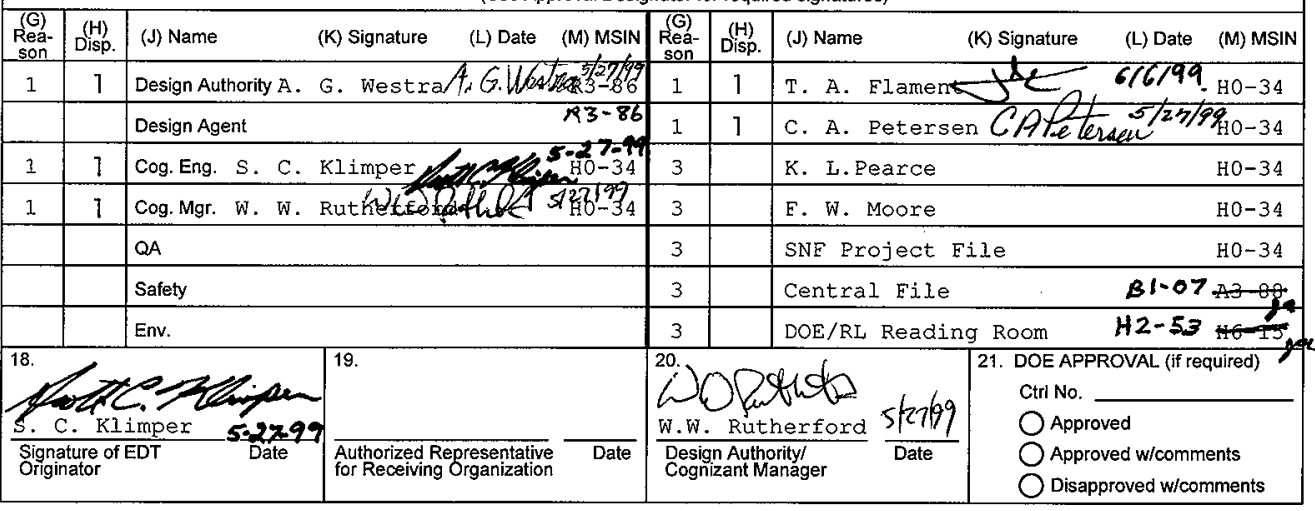




\section{K BASIN SLUDGE TREATMENT PROJECT CHEMICAL PROCESSING BASELINE TIME DIAGRAM STUDY}

S. C. Klimper

Numatec Hanford Corporation

Richland, WA 99352

U.S. Department of Energy Contract DE-AC06-96RL13200

EDT/ECN: 626920

UC: 2000

Org Code: 82500

B\&R Code: 39EW04J10 $\begin{array}{lll}\text { Charge Code: } & 105619 / \text { BA20 HN9401 } 21 ~ \mu a \\ \text { Total Pages: } & \text { T46 }\end{array}$

Key Words: time diagram, sludge treatment, K Basin, critical resource

Abstract: This document provides an initial basis for determining the duration of operating steps and the required resources for chemically treating $K$ Basin sludge before transporting it to Tank Farms. It was assumed that all operations would take place within a TPA specified 13-month timeframe.

TRADEMARK DISCLAIMER. Reference herein to any specific commercial product, process, or service by trade name trademark, manufacturer, or otherwise, does not necessarily constitute or imply its endorsement, recommendation, or favoring by the United States Government or any agency thereof or its contractors or subcontractors.

Printed in the United States of America. To obtain copies of this document, contact: Document Control Services, P.O. Box 950, Mailstop H6-08, Richland WA 99352, Phone (509) 372-2420; Fax (509) 376-4989.

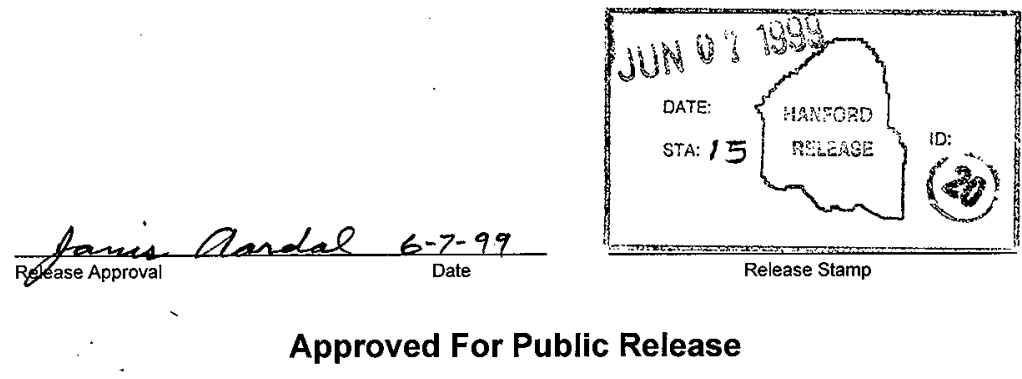


HNF-4516

Revision 0

K Basin Sludge Treatment Project Chemical Processing Baseline Time Diagram Study

Prepared by S. C. Klimper Numatec Hanford Corporation

May 1999 


\section{TABLE OF CONTENTS}

1.0 TIME DIAGRAM ALTERNATIVES ANALYSIS SUMMARY _............................................... 1

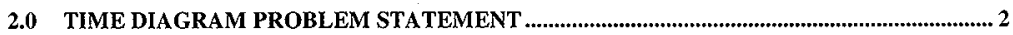

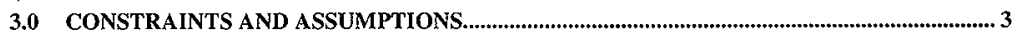

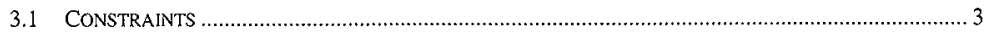

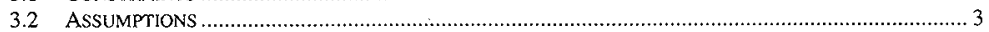

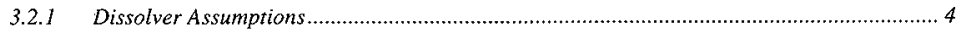

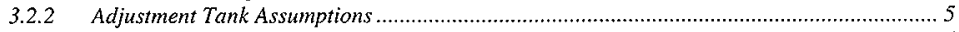

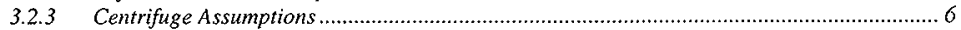

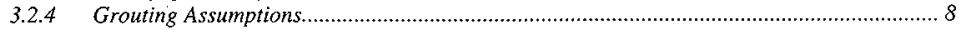

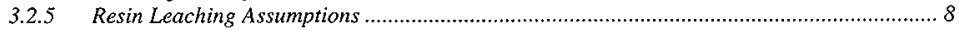

3.2.6 Process Feed Supply and Handling ....................................................................... 9

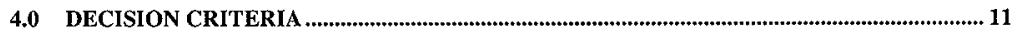

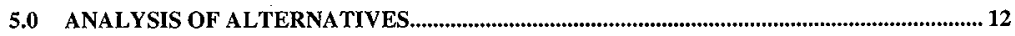

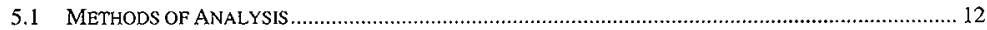

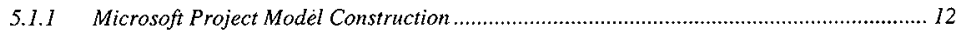

5.1.2 Calculating Impact of Scheduled Downtime .................................................................. 13

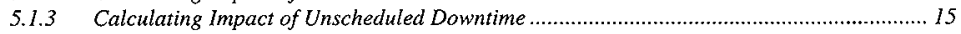

5.1.4 Calculating Resin Leaching Times ............................................................................ 18

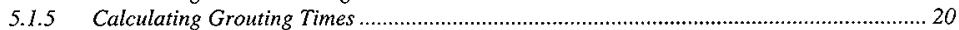

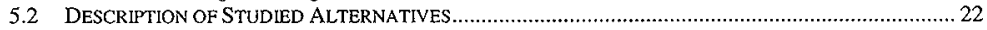

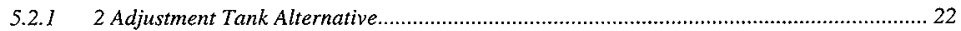

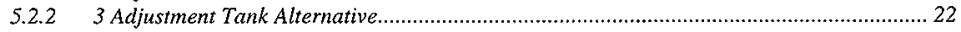

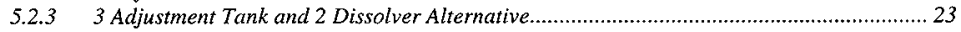

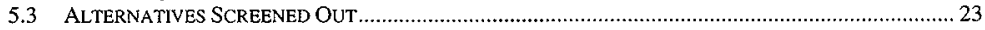

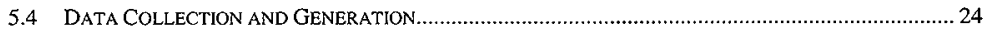

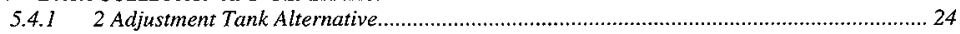

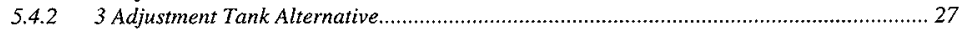

5.4 .33 Adjustment Tank and 2 Dissolver Alternative............................................................ 30

5.5 EVALUATION AND ANALYSIS OF ALTERNATIVES AGAINST DECISION CRITERIA …........................ 33

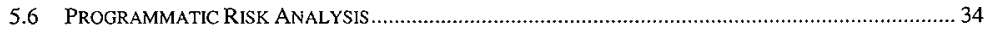

5.6.1 Sampling Turnaround and Adjustment Tank Risks....................................................... 35

5.6.2 Process Feed and Product Transportation Risks............................................................. 35

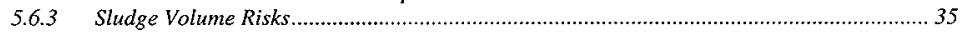

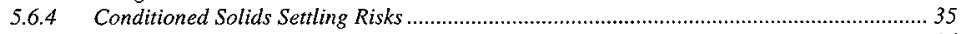

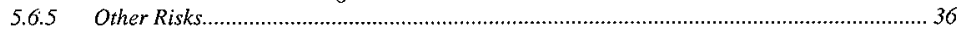

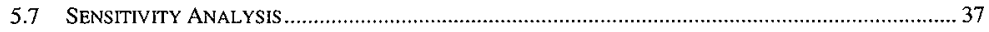

5.7.1 Sensitivities of 2 Adjustment Tank Alternative ............................................................. 38

5.7 .2 Sensitivities of 3 Adjustment Tank Alternative ............................................................ 38

5.7.3 Sensitivities of 3 Adjustment Tank and 2 Dissolver Alternative.......................................... 38

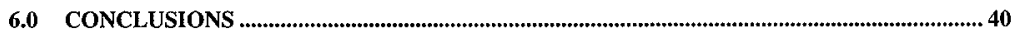

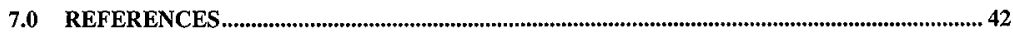

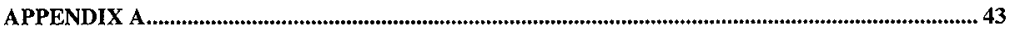

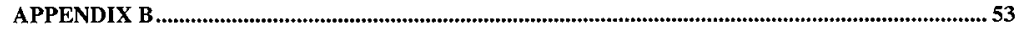

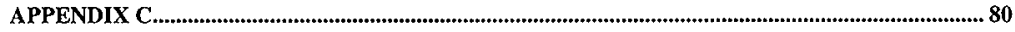


HNF-4516

Revision 0

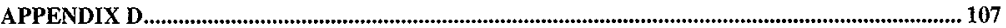

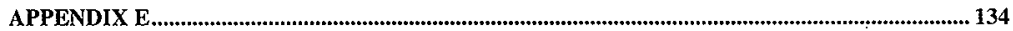


HNF-4516

Revision 0

\subsection{TIME DIAGRAM ALTERNATIVES ANALYSIS SUMMARY}

The K East (KE) and K West (KW) fuel storage basins at the $100 \mathrm{~K}$ Area of the Hanford Site contain sludge on the floor, in pits, and inside fuel storage canisters. HNF-2735, "K Basin Sludge Treatment Process Description" (Westra 1998) describes a chemical dissolution baseline process for treating the $\mathrm{K}$ Basin sludge. The purpose of this study is to provide enough information on the integrated operating time estimates of the proposed $\mathrm{K}$ Basin sludge treatment baseline process, to aid decision making with regards to quantities of resources. The acceptable operational timeframe for this baseline process is derived from sludge retrieval TPA milestones M-34-08 and M-34-10, and is 390 days. This study used the assumptions discussed in Section 3 and Appendix A to build time dependent models with a Microsoft Project platform. Based on information obtained from the optimization of these models an overall processing time was calculated for 3 resource quantity alternatives. The resource quantity alternatives considered in this study were chosen by determining the minimum resources necessary to complete processing within the specified timeframe. No effort was made to further reduce the total processing time. The three resource quantity alternatives analyzed in this study are the following:

- 2 Adjustment Tank Alternative

- 3 Adjustment Tank Alternative

- 3 Adjustment Tank and 2 Dissolver Alternative

The total processing times for these alternatives were calculated in two separate ways. The first includes the impact of scheduled downtime (maintenance/cleaning activities referred to as "Scheduled Cleanings"), and the second is without the impact of scheduled cleaning. The results of these calculations can be seen in Table 6-1 and 6-2. Table 6-1 shows the processing days, including scheduled cleanings, if $70 \%$ overall plant availability is assumed. Table $6-2$ shows the processing days without scheduled cleanings, and adjusted to $60 \%$ overall plant availability. A comparison of these tables shows that assuming a 24-hour cleaning period every 10 batches and $70 \%$ overall plant availability has results similar to assuming no scheduled downtime and $60 \%$ overall plant availability. Figures $X-1$ and $X-2$ demonstrate the performance of the alternatives over a range of availability factors.

In Section 5.5 the 3 alternatives are evaluated against the weighted decision criteria from Section 4.0. The detailed results of this analysis can be found in Section 5.5, and a summary of the results can be seen in Table 6-3. From Table 6-3 it can be seen that for the chosen criteria at the specified weights, the 3 Adjustment Tank and 2 Dissolver alternative easily had the best score. The primary driver for this was the significant weight given to total processing time as opposed to the much smaller weight given to the criteria measuring cost and operational complexity. With the minimal criteria used in this analysis, any change in weighting could cause a significant change in each alternative's score. 


\subsection{TIME DIAGRAM PROBLEM STATEMENT}

The objective of this time diagram analysis is to compare resource quantities necessary to process the $\mathrm{K}$ Basin sludge within the TPA specified timeframe, and to provide sufficient information for the decision maker(s) to determine what resources the chemical processing baseline will require. The chemical processing baseline analyzed in this study is the process described in HNF-2735, "K Basin Sludge Treatment Process Description". "Resource quantities" refers to the quantity of a particular piece of equipment that will be required. An example would be to determine whether 1 dissolver or 2 dissolvers would be required. The assumptions used to define the time diagram will ultimately determine some of the performance criteria for various equipment, but this study will not address the specifics of those performance criteria.

This study will use a set of time constraints and assumptions to enter process steps and associated durations into Microsoft Project. The process steps will each be associated with a particular piece of major equipment, as found on the SNF Project Sludge Treatment System Process Flow Diagram, H-1-81170. Project will then be used to document and evaluate the times that each piece of equipment are estimated to be in use. Using this information, alternatives will be analyzed to determine how well they satisfy established criteria.

Information and a complete listing of the criteria for this study can be found in Section 4.0 , but the primary ones are how long will it take to process all the sludge and what level of reliability and maintainability will be required. 
HNF-4516

Revision 0

\subsection{CONSTRAINTS AND ASSUMPTIONS}

\subsection{Constraints}

The only constraint considered in this study is that the TPA constraint that requires all sludge to be retrieved in a 13-month timeframe from July 31, 2004 to August 31, 2005. For this study, the TPA milestone is being interpreted to mean that all aspects of sludge processing must also be completed in this timeframe. This is assumed to include the grouting of treated solids and the used cartridge filters generated by the process. This interpretation of the TPA milestone is the conservative one, and it is expected that the only hard requirement is that sludge is retrieved by August 31, 2005.

\subsection{Assumptions}

The construction of a time diagram is based on the duration identified for each process step and the relationships of these steps to each other. In the case of a pre-conceptual process like the one being analyzed, the durations identified for each step are themselves assumptions. To formulate these time assumptions, a table was developed which attempted to define the major process steps. The major process steps were categorized according to the equipment in use for that step of the process. This developed into a rather extensive table. As a result of this, only those assumptions that help define the durations of critical resources will be discussed in this section. The complete table of assumptions can be found in Appendix A.

One overall assumption that impacts most areas of this time diagram study is that batches will not be commingled during processing. This applies to all process steps except where resins are collected and treated and the solids collection and grouting process. The main impact of this assumption is that the elutriation column is modeled as being run every batch. However, while this step delays the transfer of sludge from the Sludge Buffer Tank to the Dissolver, it does not effect any of the critical resource alternatives analyzed in this study. In other words, sludge would not necessarily be processed any faster by restricting this process step because other pieces of equipment already limit how close together batch starts can happen.

Other assumptions that impact all of the alternatives for all feed streams are the assumptions made about scheduled downtime. The impacts of scheduled downtime are discussed in Section 5.1.2, and are based on 3 assumptions. The first assumption is that scheduled maintenance or cleaning can take place while process products are still in the adjustment tanks. The second assumption is that the scheduled downtime will average 24 hours beginning to end. The third assumption is the scheduled downtime will happen once every 10 batches. Any significant changes to these assumptions could greatly impact the total processing times. 
HNF-4516

Revision 0

\subsubsection{Dissolver Assumptions}

The process steps identified in Table $3-1$ with their associated time assumptions indicate that a dissolver could be in use anywhere from 20 to 36 hours per batch of sludge.

TABLE 3-1 DISSOLVER ASSUMPTIONS

\begin{tabular}{|c|c|}
\hline Dissolve Sludge Process Steps & Assumptions \\
\hline $\begin{array}{l}\text { Add Initial Reagents to Dissolver } \\
\text { (300-500 liters) }\end{array}$ & -Will do this in 30 minutes \\
\hline Heat Dissolver Contents & -Assume 2 hours for this \\
\hline $\begin{array}{l}\text { Receive Sludge From Sludge Buffer } \\
\text { Tank }\end{array}$ & -This will be spread out over 8 hours for safety considerations \\
\hline $\begin{array}{l}\text { Complete Reaction (additional } \\
\text { reaction time required to complete } \\
\text { reaction after receiving all feed from } \\
\text { the Sludge Buffer Tank; dependent on } \\
\text { particle size and feed composition) }\end{array}$ & $\begin{array}{l}-K E 1: 4 \text { hours } \\
-\mathrm{KE} 2: 16 \text { hours } \\
\text {-KW1: } 2 \text { hours } \\
\text {-KW2: } 20 \text { hours } \\
-\mathrm{KW} 3: 12 \text { hours }\end{array}$ \\
\hline Cool Dissolver Contents & -Approximately 2 hours will be necessary for adequate cooling \\
\hline $\begin{array}{l}\text { Transfer Dissolver Contents to } \\
\text { Centrifuge }\end{array}$ & $\begin{array}{l}\text {-Transfers will occur at } 1 \mathrm{~m}^{3} / \mathrm{hr} \\
\text {-A transfer will be paused for flushing/washing whenever } 18 \\
\mathrm{~kg} \text { of solids have been accumulated in the centrifuge (e.g., } \\
\text { there will be } 2 \text { intermittent flushings per batch for KE1 feed } \\
\text { and each flushing will take } 55 \text { minutes based on centrifuge } \\
\text { assumptions); therefore the total time to transfer a batch and } \\
\text { empty the dissolver is as follows: } \\
\text { KE1: } 233 \text { minutes ( } 2 \text { intermittent flushings) } \\
\text { KE2: } 147 \text { minutes ( } 0 \text { intermittent flushings) } \\
\text { KW1: } 360 \text { minutes ( } 5 \text { intermittent flushings) } \\
\text { KW2: } 147 \text { minutes ( } 0 \text { intermittent flushings) } \\
\text { KW3: } 147 \text { minutes ( } 0 \text { intermittent flushings) }\end{array}$ \\
\hline
\end{tabular}

The most significant variable for a dissolver is the time required to sufficiently complete the desired reactions in the dissolver. These times have been estimated from ongoing laboratory work. The time required is dependent on particle size and feed composition, where the larger pieces of fuel are expected to take considerably longer to dissolve. If the feed is mostly metal oxides and insoluble components, it is expected to have smaller particle sizes and the reaction should go to completion much sooner.

The next assumption most responsible for the duration of the dissolution step is that the feed will be added to the dissolver gradually over an 8-hour period. This assumption does not currently vary from feed stream to feed stream, but since safety considerations are the driving force behind spreading the feed addition over an extended period of time, it is conceivable that different lengths of time could be used for the different feed streams. 
The last dissolver assumption discussed here deals with centrifuge limitations. The volume of slurry sent from the dissolver to the centrifuge varies from 2.2 to $2.4 \mathrm{~m}^{3}$ per batch of feed processed. The limitation is that the centrifuge can only accept the slurry at $1.0 \mathrm{~m}^{3}$ per hour. This is further impacted by the fact that if $18 \mathrm{~kg}$ of solids have been sent to the centrifuge, the centrifuge must be shut down for a rinsing operation that lasts almost an hour. It is this last point that causes the durations for $\mathrm{KE} 1$ and $\mathrm{KW} 1$ to be so much higher than the other feed streams, due to the high level of insoluble materials contained in these streams.

\subsubsection{Adjustment Tank Assumptions}

The assumptions found in Table 3-2 lead to an adjustment tank being in use for over 50 hours per batch of feed. The most time consuming assumption made for the $\mathrm{K}$ Basin sludge treatment project is that sampling and getting the results back will take 2 full days. Sampling and waiting for results currently accounts for more than $93.9 \%$ to $95.1 \%$ of the time an adjustment tank is in use. The assumption on sampling is dependent on the final infrastructure, information required, and laboratory priorities. Any of these factors could greatly influence the sampling time in either a negative or positive fashion.

Table 3-2 Adjustment Tank Assumptions

\begin{tabular}{|c|c|}
\hline Adjust Filtered Liquid Process Steps & Assumptions \\
\hline Receive and Store Filtered Liquid & $\begin{array}{l}\text {-No process restrictions } \\
\text {-Will take same time that it takes to process liquid through } \\
\text { cartridge filter, plus the } 30 \text { minutes to receive the filter rinse } \\
\text { water }\end{array}$ \\
\hline Sample and wait for results & $\begin{array}{l}\text {-Depending on infrastructure, information needed, and } \\
\text { priorities this could take anywhere from } 5 \text { hours to } 10 \text { days } \\
\text {-Will assume } 2 \text { days for initial time diagram }\end{array}$ \\
\hline Add Adjustment Reagents & $\begin{array}{l}\text {-Time varies greatly depending on amount of adjustments } \\
\text { reagents needed; } 0 \text { - } 1300 \text { liters depending on the batch } \\
\text {-Will assume } 1 \text { hour needed to transfer maximum amount; } \\
\text { This assumes no safety considerations restrict flow rate } \\
\text {-If a small amount of reagents are necessary, it is assumed a } \\
\text { minimum of } 15 \text { minutes will be required for operational } \\
\text { requirements } \\
\text {-Following are the estimated times for each feed stream: } \\
\text { KE1: } 2 \text { liters, } 15 \text { minutes } \\
\text { KE2: } 1,010 \text { liters, } 48 \text { minutes } \\
\text { KW1: } 1 \text { liter, } 15 \text { minutes } \\
\text { KW2: } 1,279 \text { liters, } 60 \text { minutes } \\
\text { KW3: } 1,121 \text { liters, } 53 \text { minutes }\end{array}$ \\
\hline $\begin{array}{l}\text { Transfer Adjusted Liquid to } \\
\text { Neutralization Tank }\end{array}$ & -Assume no flow restrictions and transfer can occur in 1 hour \\
\hline
\end{tabular}


The only other significant variable in the Adjustment Tank assumptions is the one about adding adjustment reagents. In determining these times it has been assumed that there will be no safety restrictions placed on the reagent addition rate. However, an assumption has been made that a minimum of 15 minutes will be required for this process step, no matter how small the addition. This was done to account for the actual physical steps required to perform the operation. For the $\mathrm{KEl}$ and $\mathrm{KWl}$ feed streams, it is expected that this step will not be required for all batches, but in developing the time diagram, this step has always been included. The 15-minute difference in Adjustment Tank usage is not a significant factor.

\subsubsection{Centrifuge Assumptions}

The set of assumptions used to define the duration of centrifuge operations can be found in Table 3-3. While the centrifuge is the critical resource for only one feed stream in one of the analyzed alternatives, its assumptions merit discussion for a couple of related reasons. First, the processing steps and time assumptions related to rinsing and declogging found in Table 3-3 were the ones used to build the time diagram alternatives, but since that time more accurate and detailed information about centrifuge rinsing and declogging operations has become available. However, the new information is based on a different processing plant and no final determination has been made about centrifuge operations for the SNF Sludge Treatment Project chemical processing baseline. Without a finalized operating scheme, the overall times assumed for that the rinsing and declogging operation could range from 45 minutes up to 2 hours. Secondly, if the rinsing and declogging operation is found to take 2 hours it could impact the time diagram for the $\mathrm{KE} 1$ alternative that uses 2 dissolvers and 3 adjustment tanks. All of the KEl resource alternatives use 3 total flushings for the dissolver slurry centrifugation step and 3 more for the leached dissolver slurry centrifugation step. The centrifuge is currently modeled as being dedicated to a $\mathrm{KEl}$ batch for less than 13 hours, but if the rinsing and declogging operation assumptions are changed to the longer times it could add more than 6 hours to this time. 
Table 3-3 Centrifuge Assumptions

\begin{tabular}{|c|c|}
\hline \multicolumn{2}{|l|}{ Centrifuge Dissolver Slurry } \\
\hline Clarify Dissolver Slurry & $\begin{array}{l}\text {-Dissolver slurry will be received at } 1 \mathrm{~m}^{3} / \mathrm{hr} \text {; based on this and } \\
\text { flushing/washing assumptions below, the total time to clarify a } \\
\text { batch of dissolver slurry is as follows: } \\
\text { KE1: } 283 \text { minutes ( } 3 \text { flushings total) } \\
\text { KE2: } 197 \text { minutes ( } 1 \text { flushing total) } \\
\text { KW 1: } 410 \text { minutes ( } 6 \text { flushings total) } \\
\text { KW2: } 197 \text { minutes ( } 1 \text { flushing total) } \\
\text { KW3: } 197 \text { minutes ( } 1 \text { flushing total) }\end{array}$ \\
\hline $\begin{array}{l}\text { Transfer Liquids to Clarified Liquid } \\
\text { Tank }\end{array}$ & $\begin{array}{l}\text {-No process restrictions; can occur at whatever rate the } \\
\text { centrifuge produces clarified liquid }\end{array}$ \\
\hline $\begin{array}{l}\text { Stop Centrifuge When } 18 \mathrm{~kg} \text { of Solids } \\
\text { Retained in Bowl or Done Clarifying } \\
\text { Dissolver Slurry }\end{array}$ & $\begin{array}{l}\text {-Clarification will be paused for flushing/washing whenever } \\
18 \mathrm{~kg} \text { of solids have been accumulated in the centrifuge (e.g., } \\
\text { there will be } 3 \text { flushings total per batch for KEl feed), minimal } \\
\text { time ( } 5 \text { minutes) needed to stop centrifuge and prepare for } \\
\text { flushing process }\end{array}$ \\
\hline Flush Solids Cake with Water & -Can do this in 5 minutes (60 liters) \\
\hline Homogenize Solids Cake and Water & -Can do this in 5 minutes \\
\hline Recentrifuge Homogenized Slurry & -Can do this in 10 minutes \\
\hline Flush Solids Cake With Water & -Can do this in 5 minutes (60 liters) \\
\hline Homogenize Solids Cake and Water & -Can do this in 5 minutes \\
\hline $\begin{array}{l}\text { Transfer Centrifuged Dissolver Slurry } \\
\text { to Leaching Tank }\end{array}$ & -Can do this in 5 minutes \\
\hline Prepare Centrifuge for more feed & -Can do this in 5 minutes \\
\hline \multicolumn{2}{|l|}{ Centrifuge Leached Dissolver Shurry } \\
\hline $\begin{array}{l}\text { Clarify Leached Dissolver Slurry } \\
\text { from Leaching Tank }\end{array}$ & $\begin{array}{l}\text {-Leached Dissolver slurry will be received at } 1 \mathrm{~m}^{3} / \mathrm{hr} \text {; based on } \\
\text { this and flushing/washing assumptions below, the total time to } \\
\text { clarify a batch of leached dissolver slurry is as follows: } \\
\text { KE1: } 199 \text { minutes ( } 3 \text { flushings total) } \\
\text { KE2: } 65 \text { minutes ( } 1 \text { flushing total) } \\
\text { KW 1: } 402 \text { minutes ( } 6 \text { flushings total) } \\
\text { KW2: } 66 \text { minutes ( } 1 \text { flushing total) } \\
\text { KW3: } 58 \text { minutes ( } 1 \text { flushing total) }\end{array}$ \\
\hline Flush Solids Cake With Water & -Can do this in 7 minutes ( 75 liters) \\
\hline $\begin{array}{l}\text { Transfer Leached/Flushed Dissolver } \\
\text { Slurry to Solids Reception Tank }\end{array}$ & -Can do this in 5 minutes \\
\hline
\end{tabular}


The only assumptions listed for centrifugation of the leached dissolver slurry are those that are different than the assumptions used for the dissolver slurry. All the other steps are the same.

\subsubsection{Grouting Assumptions}

A significant assumption made to simplify processing the $\mathrm{K}$ Basin sludge is that all the leached solids can be collected together in the Solids Reception Tank until all sludge processing is done. This amounts to more than $50 \mathrm{~m}^{3}$ of slurry that will need stored (Westra 1998). Inherent to this assumption is the expectation that after all $50+\mathrm{m}^{3}$ of slurry are collected, the solids can be allowed to settle, more than $33 \mathrm{~m}^{3}$ of water decanted, and still be able to homogenize the remaining $41 \mathrm{wt} \%$ slurry for sampling and processing.

The first step in grouting the conditioned solids will be to transfer the decanted liquid to the clarified liquid tank. Because the expected volume of decanted liquid is more than 33 $\mathrm{m}^{3}$, the decanting process will have to occur in phases. Previous to this step, the largest nominal volume transferred into the clarified liquid tank is 5,349 liters (Westra 1998), during the processing of feed stream $\mathrm{KW} 1$. In order to expedite the processing of the conditioned solids it is being assumed the $33+\mathrm{m} 3$ can be transferred and processed in 6 batches. This will require transfers into the clarified liquid tank of 5,500-5,600 liters.

Other process related assumptions are that there will be no cartridge filter rinsing or change out required during the processing of the decanted liquid, since the mass balances in the process description (Westra 1998) contain totals of zero for these streams. The other assumption based on the values in the process description document is that no adjustment will be required before neutralizing the solution for transport to tank farms.

A final, but significant, grout related assumption is that storage and grouting of used cartridge filters can happen concurrently with sludge processing operations. Based on this assumption the grouting of used cartridge filters would have no impact on the derived processing times for this study, and therefore is documented only in the assumptions in appendix A.

A list of all the assumptions related to grouting can be found in Appendix A.

\subsubsection{Resin Leaching Assumptions}

The assumptions in Table 3-4 apply to all of the light phase coming out of the elutriation column, not just the organic resin beads. However, the organic ion exchange resin beads do comprise a significant portion of the elutriation column's light phase for the overall process and are found primarily in feed stream KE1. The elutriation column's light phase for KE1 makes up approximately $95 \%$ of the overall process total. That is why resins (i.e., light phase from elutriation column) are modeled as being processed every 10 batches for KE1, but only once for the 22.4 batches of KE2, and only once more for all 43.8 batches of $\mathrm{KW}$ Basin sludge. As a result, these assumptions have the greatest 
impact on the processing durations derived for KE1. Based on these assumptions and those in Appendix A, it was determined that resin leaching took approximately 72 hours beginning to end for KE1. Because of the minimal impact, only two other resin leaching batches besides $\mathrm{KEl}$, this 72 hour value was used to determine the overall durations for all feed streams. In reality, because of lower volumes and solids content, the time to process the elutriation column's light phase for KE2 and all of KW will be less, but the difference is less than 1 day for the life of the process.

Table 3-4 -- Resin Leaching Assumptions

\begin{tabular}{|c|c|}
\hline Store Resin (Rẹsin Buffer Tank) & \\
\hline Store Resins & $\begin{array}{l}\text {-Will store up to } 10 \text { batches worth of light phase from the } \\
\text { Elutriation Column for } \mathrm{KE} 1 \text { (this is approximately } 108 \mathrm{~kg} \text { of } \\
\text { solids and } 514 \text { liters of slurry) before sending to the Leaching } \\
\text { Tank } \\
\text {-Will receive and store the light phase from all batches of } \mathrm{KE} 2 \\
\text { ( } 40.2 \mathrm{~kg} \text { solids, } 173 \text { liters of slurry) before sending to the } \\
\text { Leaching Tank } \\
\text {-Will receive and store the light phase from all batches of } \\
\text { KW1, KW2, and KW3 together before sending to the } \\
\text { Leaching Tank (approximately } 42 \mathrm{~kg} \text { of solids) }\end{array}$ \\
\hline Homogenize Resins & -This will take 15 minutes, or less \\
\hline Transfer Resins to Leaching Tank & $\begin{array}{l}\text { - This can be done in } 30 \text { minutes } \\
\text {-Won't start until adequate amount of resins have been } \\
\text { accumulated and the Leaching Tank is done being used to } \\
\text { leach centrifuged dissolver products }\end{array}$ \\
\hline \multicolumn{2}{|l|}{ Leach Resin Buffer Tank Contents } \\
\hline $\begin{array}{l}\text { Receive Resin Slurry from Resin } \\
\text { Buffer Tank }\end{array}$ & $\begin{array}{l}\text {-Assume this can be done in } 30 \text { minutes } \\
\text {-Resins will only be leached when a sufficient mass of solids } \\
\text { has been collected in the Resin Buffer Tank; Assume once } \\
\text { every } 10 \text { batches for } \mathrm{KE} 1 \text {, one time total for KE2, and one } \\
\text { time total for all of KW1, KW2, and KW3 }\end{array}$ \\
\hline Add Leaching Reagents & -Can do this in 30 minutes \\
\hline $\begin{array}{l}\text { Homogenize Resin Slurry to Aid } \\
\text { Leaching }\end{array}$ & -Assume this will take 4 hours \\
\hline $\begin{array}{l}\text { Transfer Leached Resin Slurry to } \\
\text { Centrifuge }\end{array}$ & $\begin{array}{l}\text {-Transfers will occur at } 1 \mathrm{~m}^{3} / \mathrm{hr} \\
\text {-A transfer will be paused for flushing/washing if } 18 \mathrm{~kg} \text { of } \\
\text { solids have been accumulated in the centrifuge }\end{array}$ \\
\hline
\end{tabular}

\subsubsection{Process Feed Supply and Handling}

The most significant process feed assumption made for this time diagram study is that process feed will be available anytime it is needed. As the Microsoft Project models discussed in Section 5.0 were being constructed and optimized, it was always assumed that when the model called for Basin sludge to be transferred to the process it would be 
available. This time diagram study did not attempt to define lag storage requirements or determine how sludge transfers from the basin would affect the lag storage system.

The assumptions in Table 3-5 only document the need for a sludge off-load system to be capable of transferring a batch of slurry containing $160 \mathrm{~kg}$ of solids into a lag storage tank in 1 hour. A fallout of the Microsoft Project models optimization is the additional requirement that the sludge retrieval, transfer, and off-load systems be capable of supplying a batch of slurry every 17 hours for the best case. It is assumed that future transport and facility studies will define the number of lag storage tanks necessary to meet these requirements, based on the integration of the proposed retrieval, transfer, and process systems.

Table 3-5 - Process Feed Assumptions

\begin{tabular}{|c|l|}
\hline Store Process Feed & \\
\hline Receive Sludge & $\begin{array}{l}\text {-Full feed batch received in one shipment } \\
\text {-Transferred in } 1 \text { hour } \\
\text {-Feed available from Sludge Removal any time it is needed }\end{array}$ \\
\hline Homogenize Feed & $\begin{array}{l}\text {-Can be adequately mixed within } 10 \text { minutes of completing } \\
\text { transfer }\end{array}$ \\
\hline Feed Screening Process & $\begin{array}{l}\text {-No process restrictions; All process feed sent to screen in } 1 \\
\text { hour }\end{array}$ \\
\hline
\end{tabular}


HNF-4516

Revision 0

\subsection{DECISION CRITERIA}

The evaluated alternatives are all based on the assumptions described in Section 3.0 and Appendix A. The only differences between the major alternatives are the total amount of time needed to process the $\mathrm{K}$ Basin sludge, specific process step times, and definition of how many of what pieces of equipment are in use. Because of this a limited number of decision criteria have been identified for this evaluation. The criteria can be found in Table 4-1.

Table 4-1 -. Time Diagram Decision Criteria

\begin{tabular}{|c|c|c|}
\hline Decision Criteria & $\begin{array}{c}\text { Criteria } \\
\text { Weighting }\end{array}$ & Comments \\
\hline $\begin{array}{l}\text { 1. The amount of time the analyzed alternative } \\
\text { takes to complete processing of all sludge. The } \\
\text { measured value will be the one that includes } \\
\text { scheduled cleanings, and is unadjusted for plant } \\
\text { availability. }\end{array}$ & $50 \%$ & $\begin{array}{l}\text { The less time it takes an } \\
\text { alternative to process all sludge, } \\
\text { the better its grade will be for } \\
\text { these criteria. If an alternative's } \\
\text { raw number is greater than } 350 \\
\text { days, it will be screened out from } \\
\text { further analysis. }\end{array}$ \\
\hline $\begin{array}{l}\text { 2. The availability estimate required for the } \\
\text { analyzed alternative to achieve compliance } \\
\text { with criteria } 1 \text { (Process all sludge in less than } \\
350 \text { days). }\end{array}$ & $30 \%$ & $\begin{array}{l}\text { The more conservative the } \\
\text { availability estimate can be for } \\
\text { the alternative, the better its grade } \\
\text { will be for these criteria. }\end{array}$ \\
\hline 3. The amount of duplicate equipment required. & $20 \%$ & $\begin{array}{l}\text { If more equipment is required to } \\
\text { meet processing goals, the project } \\
\text { will be more expensive. } \\
\text { Operation will also be more } \\
\text { complicated. Therefore, the less } \\
\text { equipment an alternative has, the } \\
\text { better its grade will be for these } \\
\text { criteria. }\end{array}$ \\
\hline
\end{tabular}

The weights applied to the criteria in Table 4-1 are based on the restricted timeframe the TPA allows for K Basin sludge removal. The constrained timeframe of the TPA also precludes the analysis of any alternative that would take more than 350 days to process the $\mathrm{K}$ Basin sludge. This is because of the need to incorporate overall plant availability factors into the analysis, and because of the possibility that the TPA could be modified or interpreted to mean all aspects of sludge removal and treatment will be completed within the 13-month timeframe.

The grade given an alternative for each criterion will range from 0-10 and be comparative to the other alternatives. For instance, the first criteria will be graded on a 150-350 processing day range, with 150 days receiving 10 points and 350 days receiving 0 points. The grade for the second criteria will be similar with $50 \%$ availability receiving 10 points and $90 \%$ availability receiving 0 points. The grade for the third criteria will be more subjective, with judgement being used to evaluate the cost and operating impacts of adding the additional equipment. 
HNF-4516

Revision 0

\subsection{ANALYSIS OF ALTERNATIVES}

\subsection{Methods of Analysis}

This analysis was performed in two distinct steps. The first step was to build model in Microsoft Project using the assumptions discussed in Section 3.0 and found in their entirety in Appendix A. A separate model was needed for each process feed stream correlated to each studied alternative. With 5 distinct feed streams and 3 resource quantity alternatives, 15 separate models were required. These models were then used to identify the critical resource for each alternative and to determine the minimum amount of time required between the starts of batches. Additional models were required to determine the length of time required for resins leaching and grouting of the treated solids. Details on the Microsoft Project models can be found in the Appendices.

The second step was to use the information from the models to calculate a total processing duration for each stream and an overall total for each alternative. The total duration includes determining the effects of scheduled and unscheduled downtime, resin leaching, and grouting of treated solids.

\subsubsection{Microsoft Project Model Construction}

The first thing required for the construction of sludge processing models in Microsoft Project was a list of all envisioned process steps listed in the anticipated sequence. The process steps were then grouped by the particular piece of equipment required for that step. Finally, estimated durations were assigned to each assumption resulting in the tables found in Section 3.0 and Appendix A.

The process steps and their durations were then entered in Microsoft Project in their anticipated sequence. This process was complicated by the determination of when steps could start in relation to previous steps, and the fact that it was necessary for some steps to be repeated at intervals dictated by other process steps. However, the use of these "predecessors" in Microsoft Project allowed the model to indicate the actual amount of time that a piece of equipment would either be in use, or at least occupied by products of the various process steps.

After building a model for I batch, the process was duplicated in order to add the processing of 5 more batches to the model. The total time required to process these 6 batches was then optimized in terms of "hours between batch starts". This optimization was accomplished by bringing the starts of batches as close together as possible without causing any piece of equipment to operate at greater than $100 \%$ availability.

The model was then used to generate the data necessary to complete calculation of an overall processing time for each feed stream within the constrictions of each alternative. 


\subsubsection{Calculating Impact of Scheduled Downtime}

The effect of scheduled downtime was calculated by determining the starting and ending times of multiple batches, determining when a scheduled downtime could begin, and comparing the totals with scheduled downtime to totals that didn't include a scheduled downtime. This was accomplished in the following manner using the 2 adjustment tank alternative and stream $\mathrm{KW} 1$ as an example:

From the model of feed stream KWI being processed by the 2 adjustment tank alternative the following data was obtained:

26 hours between the starts of batches of sludge

36 hours to get batch completely into an adjustment tank

85 hours until a batch is completely out of an adjustment tank

98 hours beginning to end (batch is in TWRS waste tank)

Using the equation

$$
(n-1) *(\text { time between batch starts })=\text { start time of batch } n
$$

it can be derived that batch 10 would start at hour 234 . It has been assumed that a scheduled downtime for cleaning, flushing, and minor maintenance would be implemented once every 10 batches. These scheduled downtimes are simply referred to as "cleanings" for the balance of the document. The cleanings are modeled to start after the $10^{\text {th }}$ batch is completely into an adjustment tank. The cleaning is then expected to last 24 hours, at which point sludge processing could resume with the start of the $11^{\text {th }}$ batch.

In this example, cleaning would start 36 hours (time to get batch completely into an adjustment tank) after batch 10 starts. This is hour 270 , and the cleaning would then end at hour 294. Batch 11 could then start at hour 294 .

However, if there were no cleanings assumed, the start time of batch 11 would be calculated as hour 260 using equation 5-1. The two different start times for batch 11 are then used to determine that cleaning adds 34 hours ( 294 hours -260 hours) to the start time of each 10 batch set, or 3.4 hours per batch. The 3.4 hours per batch value can then be added to the original hours between batch starts of 26 hours to derive the "new batch start equivalent" of 29.4 hours.

The new batch start equivalent can then be used in equation 5-1 to determine the total processing time required for the estimated 11.2 batches of sludge in feed stream KW1 using the 2 adjustment tank alternative. This is done as follows:

$(11.2$ batches -1$) *(29.4$ hours/batch $)=299.9$ hours to start batch 11.2 
If batch 11.2 starts at hour 299.9, it is then completely in an adjustment tank by hour 335.9 , and safely shipped and off-loaded at tank farms by hour 397.9 . This is the equivalent of 16.6 days to process feed stream KW1 using the 2 adjustment tank alternative and assuming a cleaning every 10 batches. This value is unadjusted for availability.

To see the overall impact of cleanings, the total processing time can be calculated for the same alternative without cleanings. Without cleanings, determine the start time of batch 11.2 using equation $5-1$ as follows:

\section{$(11.2$ batches -1$) *(26.0$ hours $/$ batch $)=265.2$ hours to start batch 11.2}

If batch 11.2 starts at hour 265.2 , it is then safely shipped and off-loaded at tank farms by hour 363.2. This is the equivalent of 15.1 days to process feed stream KWl using the 2 adjustment tank alternative and assuming no cleanings. This value is unadjusted for availability.

Therefore, cleanings add 1.5 days to the unadjusted processing time of KWl when using the 2 adjustment tank alternative. It should be noted that as the other alternatives decrease the time between batch starts, the impact of scheduled cleanings increases on a per batch basis (See Table 5-1). However, since scheduled cleaning and maintenance would be expected to give a better availability factor, a comparison is made in the next section between better availability factors with cleaning, and poorer availability factors without cleaning.

Table 5-1 - Affects of Scheduled Downtime

\begin{tabular}{|c|c|c|c|}
\hline $\begin{array}{c}\text { Time added per } \\
\text { batch by cleaning } \\
\text { for each } \\
\text { feedstream } \\
\text { (hours) }\end{array}$ & $\begin{array}{c}\text { 2 Adjustment } \\
\text { Tank Alternative }\end{array}$ & $\begin{array}{c}\text { 3 Adjustment } \\
\text { Tank Alternative }\end{array}$ & $\begin{array}{c}\text { 3 Adjustment } \\
\text { Tank and 2 } \\
\text { Dissolver } \\
\text { Alternative }\end{array}$ \\
\hline KE1 & 2.9 & 3.5 & 3.6 \\
\hline KE2 & 3.2 & 3.2 & 4.6 \\
\hline KW1 & 3.4 & 3.9 & 4.1 \\
\hline KW2 & 3.2 & 3.2 & 5.0 \\
\hline$K W 3$ & 3.2 & 3.2 & 4.3 \\
\hline
\end{tabular}




\subsubsection{Calculating Impact of Unscheduled Downtime}

Calculating the impact of unscheduled downtime in this scenario is simply a matter of applying an availability factor to the unadjusted value derived in Section 5.1.2, 16.6 days to process feed stream KW1 using the 2 adjustment tank alternative and assuming a cleaning every 10 batches. This is demonstrated as follows:

$$
\begin{gathered}
(\text { Total Days }) * \text { (Availability Factor })=(\text { Unadjusted Processing Days }) \\
\text { which then converts to }
\end{gathered}
$$$$
\text { (Unadjusted Processing Days) / (Availability Factor) }=(\text { Total Days })
$$

Applying this to the demonstration case results in:

(16.6 days $) /(.60$ availability factor $)=27.7$ total processing days at $60 \%$ availability

or

(16.6 days) $/(.70$ availability factor $)=23.7$ total processing days at $70 \%$ availability

This second value can then be compared to the total processing days required for a model with no scheduled cleanings, but at only $60 \%$ availability, in the following manner:

(15.1 days $) /(.60$ availability factor $)=25.2$ total processing days at $60 \%$ availability

For this case it can be determined that more than $10 \%$ availability is gained by regularly scheduled cleaning and maintenance, but this results in only 1.5 days being gained because of the time needed for cleaning. For other cases the results are similar, with $70 \%$ availability and scheduled cleanings being roughly equivalent $(+/-5 \%)$ to $60 \%$ availability and no scheduled cleanings.

This calculation was repeated for a range of availability factors, with the results shown in Figures 5-1 and 5-2.

These calculations were replicated using Microsoft Excel, and all the results are reported in Section 5.3 and the appendices, along with other pertinent data. 

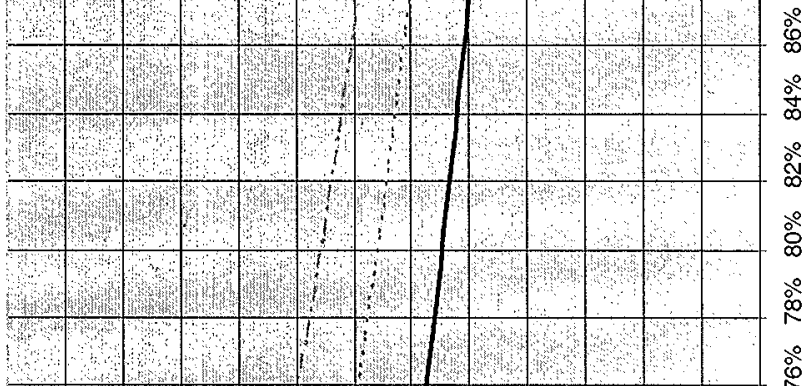

$\frac{0}{0}$

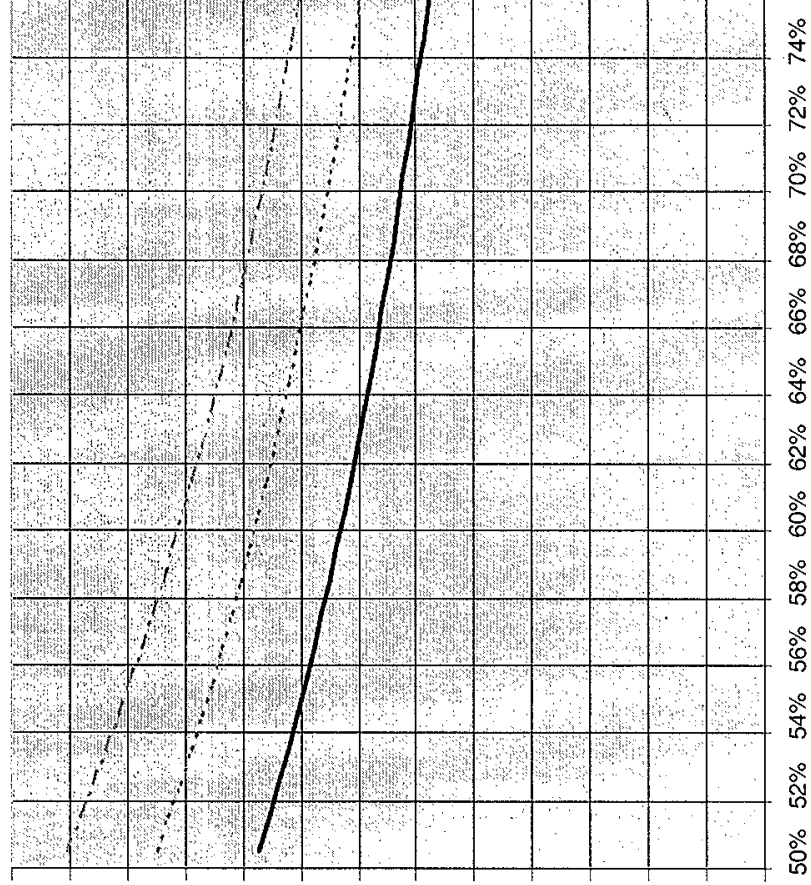

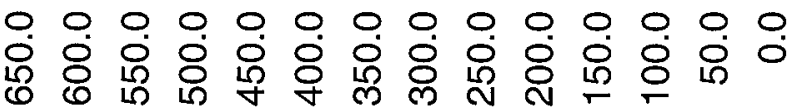

\section{skeg 6u!ssooodd}



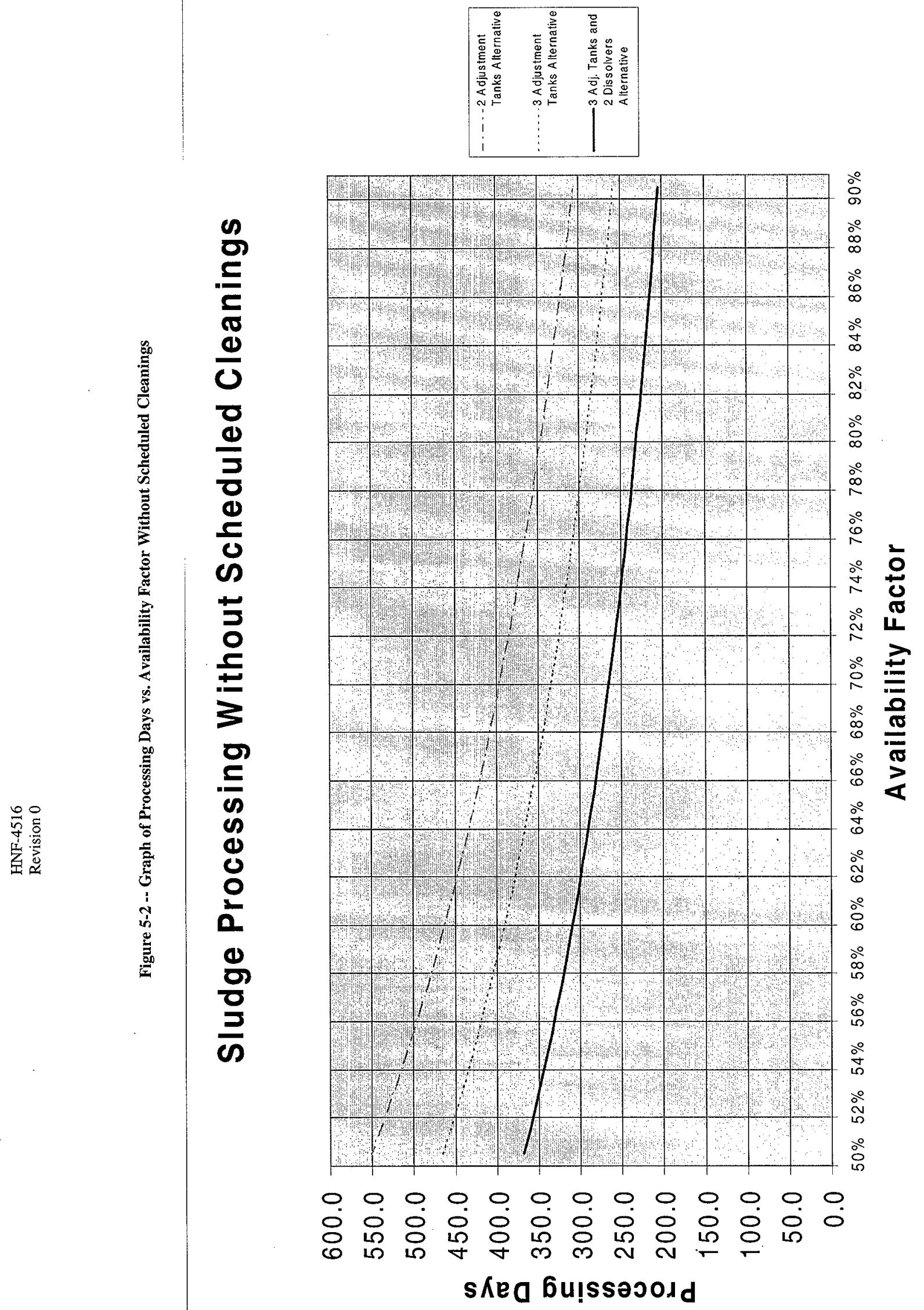


\subsubsection{Calculating Resin Leaching Times}

The process of leaching resins is similar to that of processing sludge, except the process starts with the transfer of slurry from the Resin Buffer Tank into the Leaching Tank. From the Leaching Tank to the transport of slurry to Tank Farms and the transfer of treated solids to final conditioning, the process is identical in structure in the Microsoft Project model. The only things that vary are the times assigned to the process steps. Therefore, using the Microsoft Project model for resin leaching it was determined that it would take 72 hours beginning to end to process a batch of resins from the KE1 feed stream. The 72 hour value will also be used for the KE2 and KW 1, 2, and 3 batches even though they would be expected to take 1 to 2 hours less processing time based on solids content.

Using process feed stream $\mathrm{KEl}$ and the 2 Adjustment Tank Alternative as an example, it is first noted that, per the assumptions, resins will be leached once every ten batches for $\mathrm{KE1}$. In a manner similar to that outlined in Section 5.1.2 the following start times for batch 11 can be derived:

Batch 11 with resin leaching \& cleaning would start at hour 314

Batch 11 with no resin leaching or cleaning would begin at hour 260

Since the impact of scheduled downtime shown in Table 5-1 was calculated assuming that resin leaching would take place before cleaning, the start time of batch 11 that must be derived to determine the impact of resin leaching is the one where there is resin leaching, but no cleaning. The first step in determining this is to derive from the models when the resin leaching process could begin in relation to the previous batch of sludge. Using the 10 batch example and the models it can be determined that, based on adjustment tank availability, the resin leaching process can begin 48 hours before the end of batch 10 . Since batch 10 starts at hour 234 and ends at hour 327 , this means resin leaching begins at hour 279 .

Using the models, it is determined that the resin leaching products are out of the leaching tank, centrifuge, and clarified liquid tank 12 hours after starting the resin leaching process. It is also found that the resins are out of the resin buffer tank 1 hour after starting the resin leaching process. Equally important is determining that Batch 11 of the sludge will need the leaching tank, centrifuge, and clarified liquid tank 18 hours after starting, and the resin buffer tank 2 hours after starting.

Using this data, it is then determined that based on leaching tank, centrifuge, and clarified liquid tank availability, batch 11 could start at hour 273 (hour 279 start time +12 hours to vacate equipment -18 hours equipment needed after starting). In the same way it is determined that based on resin buffer tank availability, batch 11 could start at hour 278 (hour 279 start time +1 hour to vacate equipment -2 hours equipment needed after starting). However, since this alternative only has 2 adjustment tanks, and batch 10 starts 
at hour 234 and is out of the adjustment tank batch 11 will require at hour 315 , batch 11 could start 30 hours before the adjustment tank is available. This would have batch 11 starting at hour 285 . From all of this it can be seen that the earliest batch 11 could start is hour 285 .

Calculating the time impact of leaching resins is then accomplished in a manner similar to the cleaning time impact discussed in Section 5.1.2. Batch 11 with resin leaching (no cleaning) can start at hour 285 , and batch 11 with no resin leaching or cleaning can begin at hour 260 . Therefore, the time added by processing resins for feed stream KEl is 25 hours ( 285 hours -260 hours) for a 10 batch set, or 2.5 hours per batch.

To simplify the replication of this calculation in Microsoft Excel and to make it more compatible with the other calculations, it was decided that a value called "Total Processing Hours Added By Resin Processing" should be calculated for each feed stream for each alternative. This was done in the following manner:

(\# of batches) $*$ (\# of hours added by resin processing $/$ batch $)=$ total time added by resins Continuing the previous example, it can be shown that

$$
(146.1 \text { batches }) *(2.5 \text { hours added } / \text { batch })=365 \text { total hours }
$$

For the 2 Adjustment Tank Alternative to process feed stream KE1, there are 365 hours added to the total feed stream processing time by the processing of resins.

Based on the assumptions discussed in Section 3.2 and Appendix A, this calculation was only done for KE1, KE2, and following KW3. Since the light phase from the elutriation column will be stored for all batches of $\mathrm{K}$ West Basin sludge, it has been assumed that they will be processed in order and that the final batch of resin processed will take place following the processing of feed stream KW3. The results of these calculations can be found in Table 5-2.

Table 5-2 - Resin Leaching Impacts

\begin{tabular}{|c|c|c|c|}
\hline $\begin{array}{c}\text { Total Time added } \\
\text { by Resin } \\
\text { Leaching (hours) }\end{array}$ & $\begin{array}{c}\text { 2 Adjustment } \\
\text { Tank Alternative }\end{array}$ & $\begin{array}{c}\text { 3 Adjustment } \\
\text { Tank Alternative }\end{array}$ & $\begin{array}{c}\text { 3 Adjustment } \\
\text { Tank and 2 } \\
\text { Dissolver } \\
\text { Alternative }\end{array}$ \\
\hline KE1 & 365 & 132 & 278 \\
\hline KE2 & 17 & 9 & 13 \\
\hline KW3 & 21 & 9 & 15 \\
\hline
\end{tabular}




\subsubsection{Calculating Grouting Times}

The calculation of the time required to grout treated solids was broken into two parts. The first part is the process of decanting excess liquid and processing it for transport to tank farms. The second part is then the grouting of the remaining slurry. This "calculation" was accomplished in a different manner than those previously described. Based on the assumptions found in section 3.2.4 and Appendix A, as well as the data contained in Westra (1998), the whole grouting process can be accomplished with the processing of 6 batches of excess liquid and the filling and transport of 7 grout liners. Because of the limited nature of this process, the Microsoft Project model built to represent the grout process was expanded to model all steps, assuming an alternative with 3 adjustment tanks is in use. Figure 5-3 shows all the summary steps, their durations, and the availability and use of the required resources. An evaluation of this model shows that the whole process will take about 30 days. This has not been adjusted for overall plant availability or reliability. 


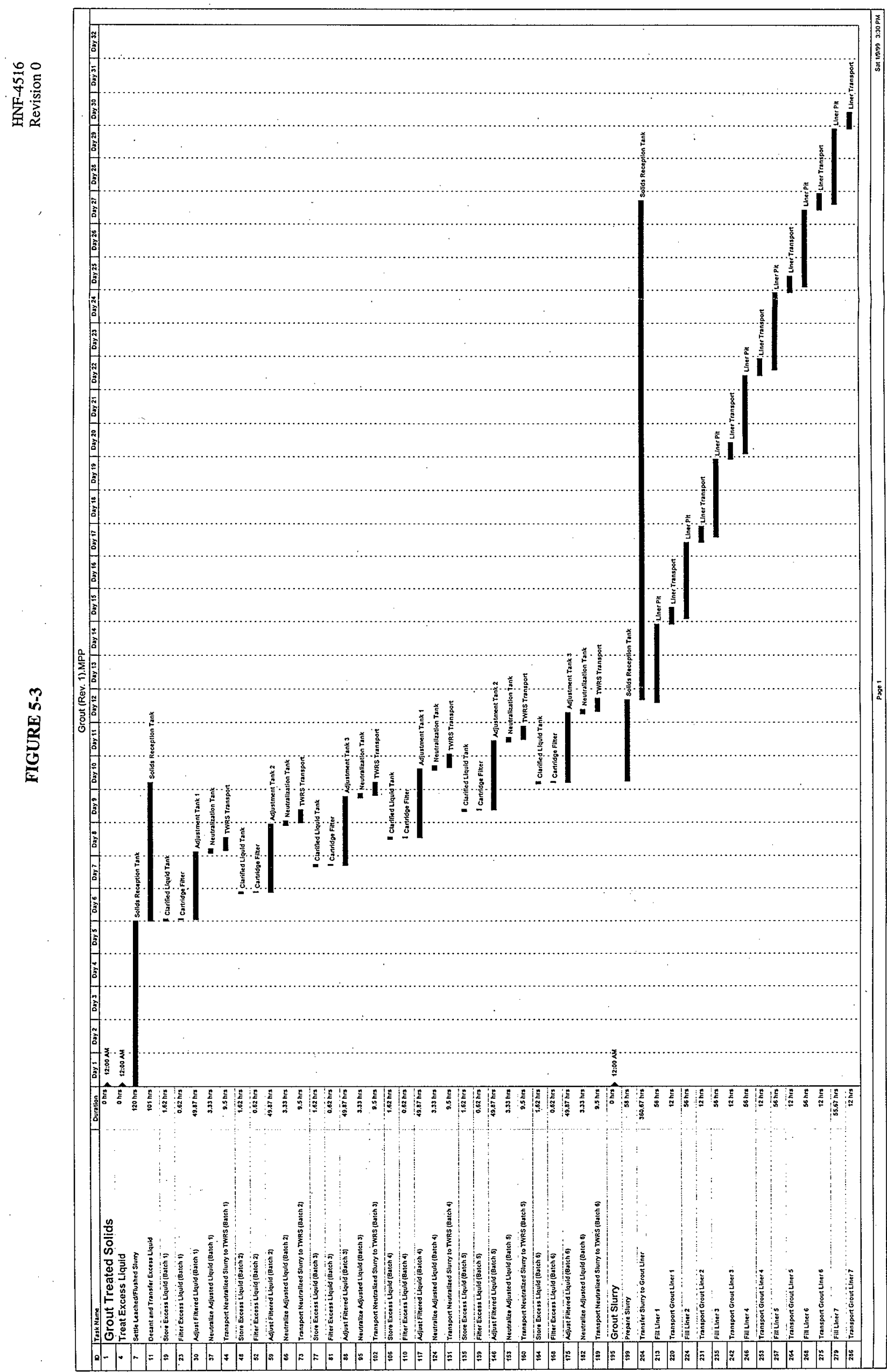




\subsection{Description of Studied Alternatives}

The three analyzed resource quantity alternatives are identical in structure for a given feed stream. In other words, the time required to complete specific process steps does not vary from one alternative to another for a given feed stream. The addition of duplicate equipment allows the structure to be further condensed or optimized, which results in reduced times between the start of batches. This might also result in a change of the critical resource for a given feed stream. The critical resource is the piece of equipment or other resource that limits or prevents further minimization of overall sludge processing times. This is reflected in the minimum hours required between the start of batches. However, the time required to process a batch of sludge from a given feed stream remains the same from one alternative to another. One general purpose of this study was to determine the quantity of specific resources that would be necessary to process all the sludge in a given timeframe.

\subsubsection{Adjustment Tank Alternative}

The 2 adjustment tank alternative is the simplest alternative considered. Simply stated, it consists of one piece of every kind of equipment found in the Sludge Treatment System Process Flow Diagram, $\mathrm{H}-1-81170$, plus one additional adjustment tank. The time between the start of batches for this alternative range from 26 hours to 36 hours. For the feed streams with shorter dissolution times, KEl and KW1, the critical resources are the adjustment tanks. For feed streams with longer dissolution times the critical resource is the dissolver.

\subsubsection{Adjustment Tank Alternative}

The 3 adjustment tank alternative adds an additional, or third, adjustment tank to the alternative described in the previous section. The time between the start of batches for this alternative range from 21 to 36 hours. The only feed streams where the time between batches was shortened by adding a third adjustment tank were KEI and KWl, the ones where the adjustment tank was identified as the critical resource. However, since KE1 accounts for approximately $60 \%$ of the required processing days, the total sludge processing time would be reduced by more than $10 \%$ by adding a third adjustment tank. The supporting data for this can be found in Table 5-3. 
Table 5-3 - Processing Days Including Scheduled Cleanings

\begin{tabular}{|c|c|c|c|}
\hline \multicolumn{4}{|c|}{ Not Adjusted for Availability } \\
\hline Stream & $\begin{array}{c}\text { 2 Adjustment } \\
\text { Tanks } \\
\text { Aiternative }\end{array}$ & $\begin{array}{c}\text { 3 Adjustment } \\
\text { Tanks } \\
\text { Alternative }\end{array}$ & $\begin{array}{c}\text { 3 Adj. Tanks } \\
\text { and 2 } \\
\text { Dissolvers } \\
\text { Alternative }\end{array}$ \\
\hline KE1 & 193.8 & 157.5 & 140.0 \\
KE2 & 39.3 & 39.0 & 26.9 \\
KW1 & 16.6 & 14.7 & 13.9 \\
KW2 & 19.5 & 19.5 & 13.3 \\
KW3 & 32.8 & 32.3 & 23.7 \\
\hline Total Days & 302.0 & 263.0 & 217.8 \\
\hline
\end{tabular}

\subsubsection{Adjustment Tank and 2 Dissolver Alternative}

The final analyzed alternative adds a second dissolver to the 3 adjustment tank alternative. The time between the start of batches for this alternative range from 17 to 19 hours, with all feed streams having a corresponding drop in the number of days required to process. The total sludge processing time would be reduced by more than $17 \%$ by adding a second dissolver to the 3 adjustment tank alternative (See Table 5-3).

\subsection{Alternatives Screened Out}

The first alternative that was screened out and not analyzed in detail was one where there would be only 1 adjustment tank. This alternative would add approximately 24 hours to the minimum time allowed between the start of batches for the KE1 feed stream. It was determined that this alternative would greatly exceed the constraint of being able to process all the sludge in a 13 -month timeframe. This is easily demonstrated by the fact that the 2 adjustment tank alternative requires an optimistic availability factor to meet the specified constraint.

The second alternative screened out was one where a fourth adjustment tank could be added to the 3 adjustment tank and 2 dissolver alternative. This alternative has the potential to shorten the time between batch starts by more than 2 or 3 hours for the 3 process feed streams (KE1, KE2, and KW3) which account for more than $87 \%$ of the processing days calculated for the 3 adjustment tank and 2 dissolver alternative. However, since the 3 adjustment tank and 2 dissolver alternative should be able to process the $\mathrm{K}$ Basin sludge within the specified timeframe assuming a reasonable availability factor. Based on this it was determined that adding a fourth adjustment tank at this time would give the appearance of minimizing sludge processing times as opposed to optimizing the processing times against resources. If the required availability factor is determined to be overly optimistic, or the estimate of sludge requiring processing increases, this alternative should be revisited.

No other alternatives have been considered at this time. 
HNF-4516

Revision 0

\subsection{Data Collection and Generation}

This section contains the data and summary information derived from the Microsoft Project models and the associated calculations described in section 5 . It has been grouped by alternative where appropriate.

\subsubsection{Adjustment Tank Alternative}

Figure 5-4 contains the results of the Microsoft Project model for this alternative processing feed stream KEl. Figure 5-4 shows the summary steps for a four-batch progression with associated resource usage. For this alternative and feed stream, it can be seen that the adjustment tanks are the critical resource. Similar figures for this alternative processing the other feed streams can be found in Appendix B. 


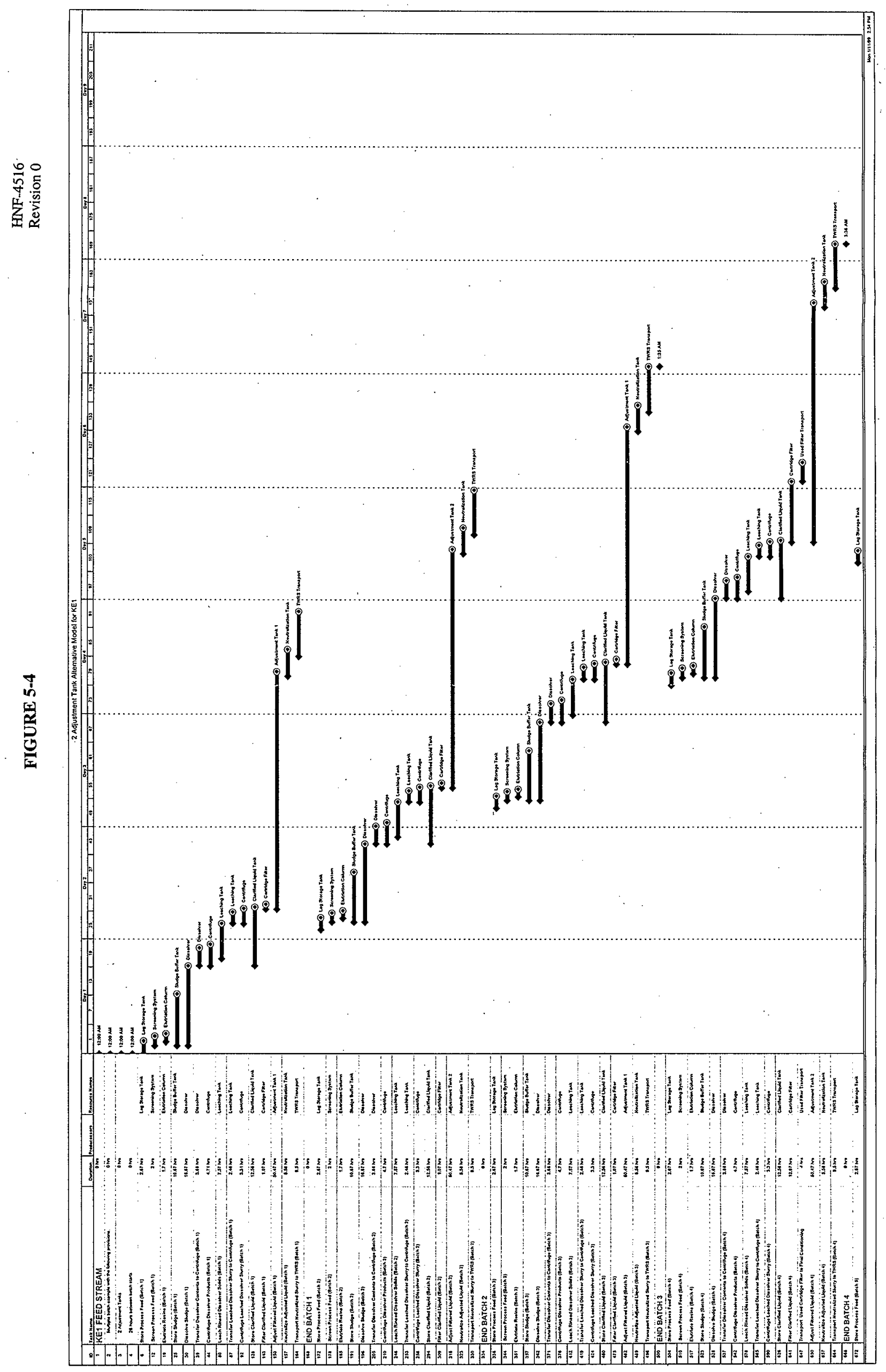


The data gathered from the five feed stream models for the 2 adjustment tank alternative is summarized in Table 5-4. Table 5-4 also includes the results of the resin processing calculation described earlier.

Table 5-4 - 2 Adjustment Tank Alternative Data

\begin{tabular}{|l|c|c|c|c|c|}
\hline & \multicolumn{5}{|c|}{ Process Feed Stream } \\
\cline { 2 - 6 } & $\mathrm{KE1}$ & $\mathrm{KE} 2$ & $\mathrm{KW} 1$ & $\mathrm{KW} 2$ & $\mathrm{KW} 3$ \\
\hline Hours between batch starts & 26 & 32 & 26 & 36 & 28 \\
\hline $\begin{array}{l}\text { Hours to get batch } \\
\text { completely into adjustment } \\
\text { tank }\end{array}$ & 32 & 40 & 36 & 44 & 36 \\
\hline $\begin{array}{l}\text { Hours until batch is out of } \\
\text { adjustment tank }\end{array}$ & 81 & 90 & 85 & 94 & 86 \\
\hline $\begin{array}{l}\text { Hours beginning to end for } \\
\text { one batch }\end{array}$ & 93 & 103 & 98 & 107 & 99 \\
\hline $\begin{array}{l}\text { Total Processing Hours } \\
\text { Added by Resin Processing }\end{array}$ & 365 & 17 & 0 & 0 & 21 \\
\hline $\begin{array}{l}\text { Total Batches for feed } \\
\text { stream }\end{array}$ & 146.1 & 24.4 & 11.2 & 10.2 & 22.4 \\
\hline
\end{tabular}

The information in Table 5-4 was then used to perform the calculations described in Section 5.1, and Microsoft Excel was used to replicate the calculations. The resulting data can be found in Table 5-5.

Table 5-5 - Calculation Results for 2 Adj. Tanks Alternative

\begin{tabular}{|c|c|c|c|c|c|c|c|c|}
\hline $\begin{array}{c}\text { Process } \\
\text { Feed } \\
\text { Stream }\end{array}$ & $\begin{array}{c}\text { Batch 10 } \\
\text { start }\end{array}$ & $\begin{array}{c}\text { Cleaning } \\
\text { Start }\end{array}$ & $\begin{array}{c}\text { Batch 11 } \\
\text { Start }\end{array}$ & $\begin{array}{c}\text { Batch 11 } \\
\text { Start } \\
\text { without } \\
\text { cleaning }\end{array}$ & $\begin{array}{c}\text { Time } \\
\text { added per } \\
\text { batch by } \\
\text { cleaning }\end{array}$ & $\begin{array}{c}\text { New } \\
\text { Batch } \\
\text { Start } \\
\text { Equivalent }\end{array}$ & $\begin{array}{c}\text { End Time } \\
\text { of Final } \\
\text { Batch }\end{array}$ & $\begin{array}{c}\text { End Time } \\
\text { of Final } \\
\text { Batch } \\
\text { Without } \\
\text { Cleaning }\end{array}$ \\
\hline KE1 & 234 & 290 & 314 & 285 & 2.9 & 28.9 & 4651.4 & 4230.6 \\
\hline KE2 & 288 & 328 & 352 & 320 & 3.2 & 35.2 & 943.7 & 868.8 \\
\hline KW1 & 234 & 270 & 294 & 260 & 3.4 & 29.4 & 397.9 & 363.2 \\
\hline KW2 & 324 & 368 & 392 & 360 & 3.2 & 39.2 & 467.6 & 438.2 \\
\hline KW3 & 252 & 288 & 312 & 280 & 3.2 & 31.2 & 787.7 & 719.2 \\
\hline
\end{tabular}

] Excel is a trademark of Microsoft Corporation. 
The calculated data from Table $5-5$ can then be converted into the final and most pertinent answer, resulting in Table 5-6. Table 5-6 contains the total processing days for the 2 Adjustment Tank Alternative with and without the assumed cleaning process. It is important to remember that these values have not been adjusted for overall plant availability.

Table 5-6 - Total Processing Days for 2 Adj. Tank Alt.

\begin{tabular}{|c|c|c|}
\hline $\begin{array}{c}\text { Process Feed } \\
\text { Stream }\end{array}$ & $\begin{array}{c}\text { Time to Process } \\
\text { Stream with } \\
\text { Cleaning (Days) }\end{array}$ & $\begin{array}{c}\text { Time to Process } \\
\text { Stream without } \\
\text { Cleaning (Days) }\end{array}$ \\
\hline KE1 & 193.8 & 176.3 \\
\hline KE2 & 39.3 & 36.2 \\
\hline KW1 & 16.6 & 15.1 \\
\hline KW2 & 19.5 & 18.3 \\
\hline KW3 & 32.8 & 30.0 \\
\hline Total & $\mathbf{3 0 2 . 0}$ & $\mathbf{2 7 5 . 8}$ \\
\hline
\end{tabular}

\subsubsection{Adjustment Tank Alternative}

Figure 5-5 contains the results of the Microsoft Project ${ }^{2}$ model for this alternative processing feed stream KE1. Figure 5-5 shows the summary steps for a four-batch progression with associated resource usage. For this alternative and feed stream, it can be determined from the model that the dissolver is the critical resource. Similar figures for this alternative processing the other feed streams can be found in Appendix C.

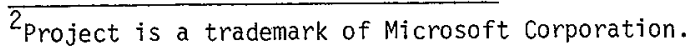




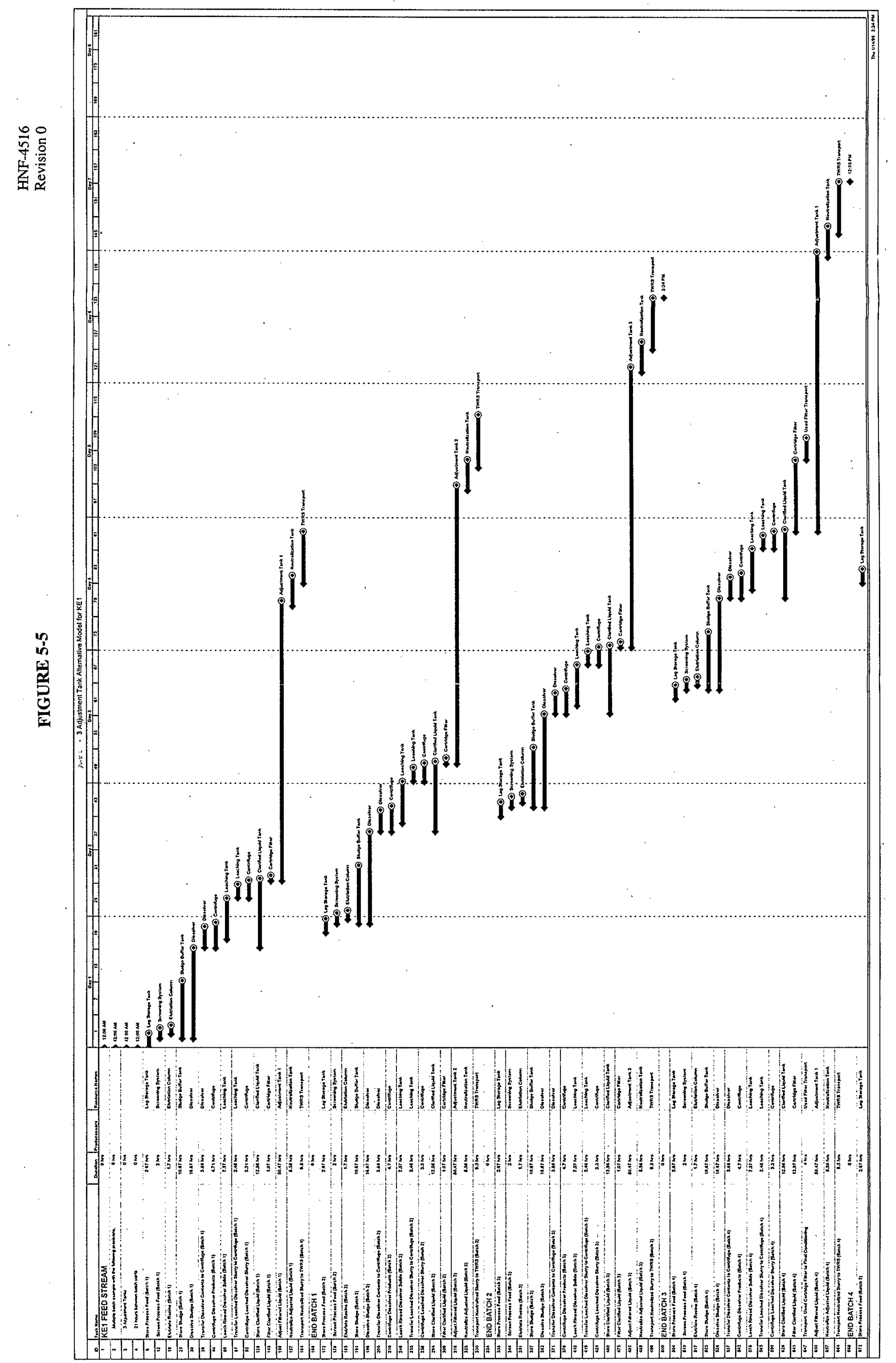


The data gathered from the five feed stream models for the 3 Adjustment Tank alternative is summarized in Table 5-7. Table 5-7 also includes the results of the resin processing calculations.

Table 5-7 - 3 Adjustment Tank Alternative

\begin{tabular}{|c|c|c|c|c|c|}
\hline & \multicolumn{5}{|c|}{ Process Feed Stream } \\
\cline { 2 - 6 } & KE1 & KE2 & KW1 & KW2 & KW3 \\
\hline Hours between batch starts & 21 & 32 & 21 & 36 & 28 \\
\hline $\begin{array}{c}\text { Hours to get batch } \\
\text { completely into adjustment } \\
\text { tank }\end{array}$ & 32 & 40 & 36 & 44 & 36 \\
\hline $\begin{array}{c}\text { Hours until batch is out of } \\
\text { adjustment tank }\end{array}$ & 81 & 90 & 85 & 94 & 86 \\
\hline $\begin{array}{c}\text { Hours beginning to end for } \\
\text { one batch }\end{array}$ & 93 & 103 & 98 & 107 & 99 \\
\hline $\begin{array}{c}\text { Total Processing Hours } \\
\text { Added by Resin Processing }\end{array}$ & 132 & 9 & 0 & 0 & 9 \\
\hline $\begin{array}{c}\text { Total Batches for feed } \\
\text { stream }\end{array}$ & 146.1 & 24.4 & 11.2 & 10.2 & 22.4 \\
\hline
\end{tabular}

The information in Table 5-7 was then used to perform the calculations described in Section 5.1, and Microsoft Excel was used to replicate the calculations. The resulting data can be found in Table 5-8.

Table 5-8 - Calculation Results for 3 Adj. Tanks Alternative

\begin{tabular}{|c|c|c|c|c|c|c|c|c|}
\hline $\begin{array}{c}\text { Process } \\
\text { Feed } \\
\text { Stream }\end{array}$ & $\begin{array}{c}\text { Batch 10 } \\
\text { start }\end{array}$ & $\begin{array}{c}\text { Cleaning } \\
\text { Start }\end{array}$ & $\begin{array}{c}\text { Batch 11 } \\
\text { Start }\end{array}$ & $\begin{array}{c}\text { Batch 11 } \\
\text { Start } \\
\text { without } \\
\text { cleaning }\end{array}$ & $\begin{array}{c}\text { Time } \\
\text { added per } \\
\text { batch by } \\
\text { cleaning }\end{array}$ & $\begin{array}{c}\text { New } \\
\text { Batch } \\
\text { Start } \\
\text { Equivalent }\end{array}$ & $\begin{array}{c}\text { End Time } \\
\text { of Final } \\
\text { Batch }\end{array}$ & $\begin{array}{c}\text { End Time } \\
\text { of Final } \\
\text { Batch } \\
\text { Without } \\
\text { Cleaning }\end{array}$ \\
\hline KE1 & 189 & 230 & 254 & 219 & 3.5 & 24.5 & 3780.0 & 3272.1 \\
\hline KE2 & 288 & 328 & 352 & 320 & 3.2 & 35.2 & 935.7 & 860.8 \\
\hline KW1 & 189 & 225 & 249 & 210 & 3.9 & 24.9 & 352.0 & 312.2 \\
\hline KW2 & 324 & 368 & 392 & 360 & 3.2 & 39.2 & 467.6 & 438.2 \\
\hline KW3 & 252 & 288 & 312 & 280 & 3.2 & 31.2 & 775.7 & 707.2 \\
\hline & & \multicolumn{7}{|c|}{ All values are in hours } \\
\hline
\end{tabular}

The data in the final 2 columns of Table 5-8 were then converted into days to provide an easily understood basis for comparison with the other alternatives. This data is reported in Table 5-9 as the total processing days for the 3 Adjustment Tank Alternative with and 
without the assumed cleaning process. It is important to remember that these values have not been adjusted for overall plant availability.

Table 5-9 - Total Processing Days for 3 Adj. Tank Alt.

\begin{tabular}{|c|c|c|}
\hline $\begin{array}{c}\text { Process Feed } \\
\text { Stream }\end{array}$ & $\begin{array}{c}\text { Time to Process } \\
\text { Stream with } \\
\text { Cleaning (Days) }\end{array}$ & $\begin{array}{c}\text { Time to Process } \\
\text { Stream without } \\
\text { Cleaning (Days) }\end{array}$ \\
\hline KE1 & 157.5 & 136.3 \\
\hline KE2 & 39.0 & 35.9 \\
\hline KW1 & 14.7 & 13.0 \\
\hline KW2 & 19.5 & 18.3 \\
\hline KW3 & 32.3 & 29.5 \\
\hline Total & 263.0 & 232.9 \\
\hline
\end{tabular}

\subsubsection{Adjustment Tank and 2 Dissolver Alternative}

Figure 5-6 contains the results of the Microsoft Project model for this alternative processing feed stream KE1. Figure 5-6 shows the summary steps for a four-batch progression with associated resource usage. For this alternative and feed stream, it can be determined from the model that the time between batch starts has been reduced to 17 hours, but the adjustment tanks are again the critical resource. Similar figures for this alternative processing the other feed streams can be found in Appendix D. 


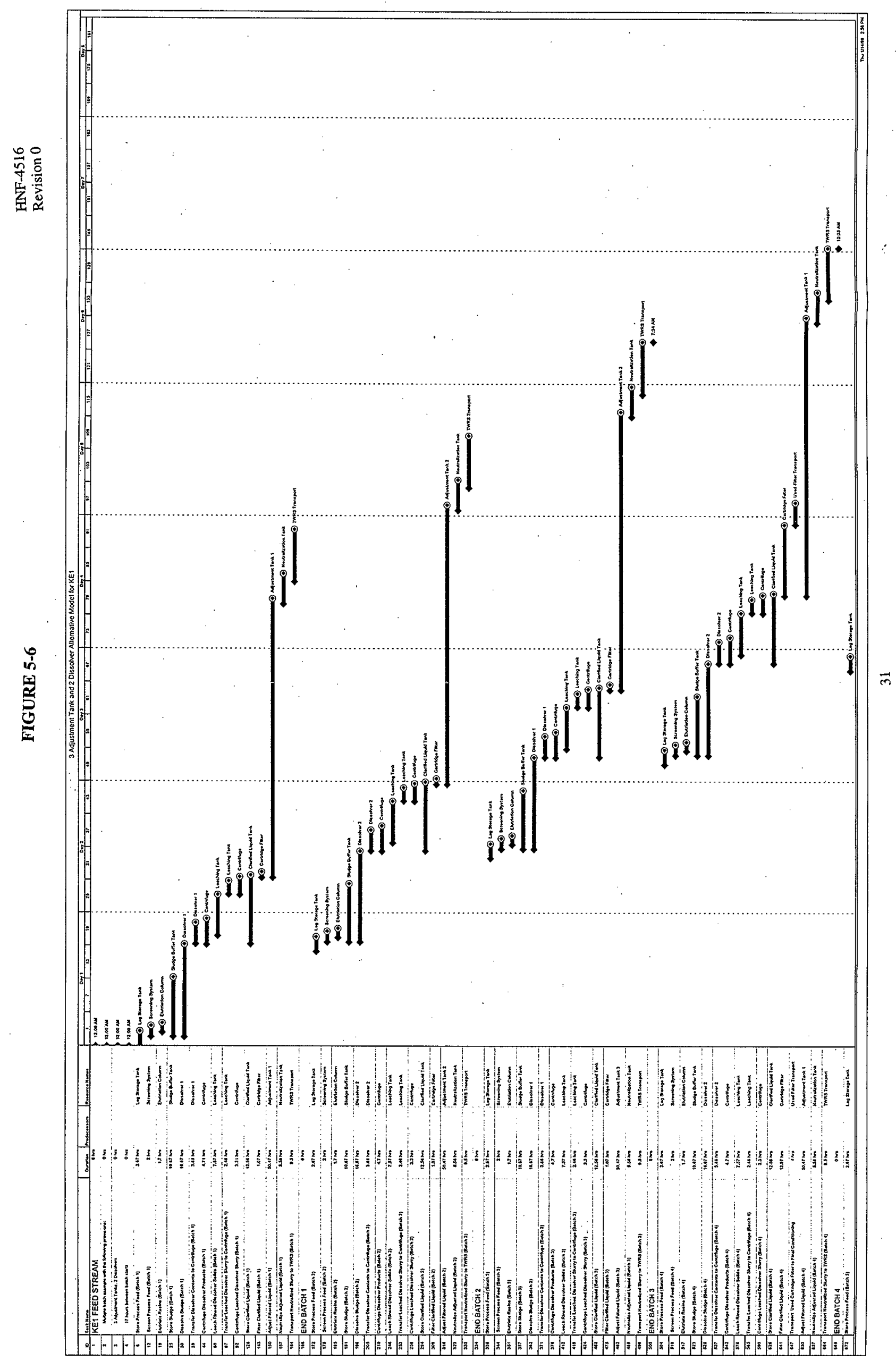


The data gathered from the five feed stream models for the 3 Adjustment Tank and 2 Dissolver alternative is summarized in Table 5-10. Table 5-10 also includes the results of the resin processing calculations for this altemative.

Table 5-10 - 3 Adjustment Tank and 2 Dissolver Alternative Data

\begin{tabular}{|c|c|c|c|c|c|}
\hline & \multicolumn{5}{|c|}{ Process Feed Stream } \\
\cline { 2 - 6 } & KE1 & KE2 & KW1 & KW2 & KW3 \\
\hline Hours between batch starts & 17 & 18 & 19 & 18 & 17 \\
\hline $\begin{array}{c}\text { Hours to get batch } \\
\text { completely into adjustment } \\
\text { tank }\end{array}$ & 32 & 40 & 36 & 44 & 36 \\
\hline $\begin{array}{c}\text { Hours until batch is out of } \\
\text { adjustment tank }\end{array}$ & 81 & 90 & 85 & 94 & 86 \\
\hline $\begin{array}{c}\text { Hours beginning to end for } \\
\text { one batch }\end{array}$ & 93 & 103 & 98 & 107 & 99 \\
\hline $\begin{array}{c}\text { Total Processing Hours } \\
\text { Added by Resin Processing }\end{array}$ & 278 & 13 & 0 & 0 & 15 \\
\hline $\begin{array}{c}\text { Total Batches for feed } \\
\text { stream }\end{array}$ & 146.1 & 24.4 & 11.2 & 10.2 & 22.4 \\
\hline
\end{tabular}

The information in Table 5-10 was used to perform the calculations described in Section 5.1 , and Microsoft Excel was used to replicate the calculations. The resulting data is in Table 5-11.

Table 5-11 - Calculation Results for 3 Adj. Tanks and 2 Dissolver Alternative

\begin{tabular}{|c|c|c|c|c|c|c|c|c|}
\hline $\begin{array}{c}\text { Process } \\
\text { Feed } \\
\text { Stream }\end{array}$ & $\begin{array}{c}\text { Batch 10 } \\
\text { start }\end{array}$ & $\begin{array}{c}\text { Cleaning } \\
\text { Start }\end{array}$ & $\begin{array}{c}\text { Batch 11 } \\
\text { Start }\end{array}$ & $\begin{array}{c}\text { Batch 11 } \\
\text { Start } \\
\text { without } \\
\text { cleaning }\end{array}$ & $\begin{array}{c}\text { Time } \\
\text { added per } \\
\text { batch by } \\
\text { cleaning }\end{array}$ & $\begin{array}{c}\text { New } \\
\text { Batch } \\
\text { Start } \\
\text { Equivalent }\end{array}$ & $\begin{array}{c}\text { End Time } \\
\text { of Final } \\
\text { Batch }\end{array}$ & $\begin{array}{c}\text { End Time } \\
\text { of Final } \\
\text { Batch } \\
\text { Without } \\
\text { Cleaning }\end{array}$ \\
\hline KE1 & 153 & 201 & 225 & 189 & 3.6 & 20.6 & 3360.1 & 2837.7 \\
\hline KE2 & 162 & 202 & 226 & 180 & 4.6 & 22.6 & 644.8 & 537.2 \\
\hline KW1 & 171 & 207 & 231 & 190 & 4.1 & 23.1 & 333.6 & 291.8 \\
\hline KW2 & 162 & 206 & 230 & 180 & 5 & 23 & 318.6 & 272.6 \\
\hline KW3 & 153 & 189 & 213 & 170 & 4.3 & 21.3 & 569.8 & 477.8 \\
\hline \multicolumn{70}{|c|}{ All values are in hours } \\
\hline
\end{tabular}


The data in the final 2 columns of Table 5-11 were then converted into days to provide an easily understood basis for comparison with the other alternatives. This data is reported in Table 5-12 as the total processing days for the 3 Adjustment Tank and 2 Dissolver Alternative with and without the assumed cleaning process. It is important to remember that these values have not been adjusted for overall plant availability as discussed in Section 5.1.3 and displayed in Figures $1-1$ and 1-2.

Table 5-12 - Total Processing Days for 3 Adj. Tank and 2 Dissolver Alternative

\begin{tabular}{|c|c|c|}
\hline $\begin{array}{c}\text { Process Feed } \\
\text { Stream }\end{array}$ & $\begin{array}{c}\text { Time to Process } \\
\text { Stream with } \\
\text { Cleaning (Days) }\end{array}$ & $\begin{array}{c}\text { Time to Process } \\
\text { Stream without } \\
\text { Cleaning (Days) }\end{array}$ \\
\hline KE1 & 140.0 & 118.2 \\
\hline KE2 & 26.9 & 22.4 \\
\hline KW1 & 13.9 & 12.2 \\
\hline KW2 & 13.3 & 11.4 \\
\hline KW3 & 23.7 & 19.9 \\
\hline Total & $\mathbf{2 1 7 . 8}$ & $\mathbf{1 8 4 . 0}$ \\
\hline
\end{tabular}

\subsection{Evaluation and Analysis of Alternatives against Decision Criteria}

Each alternative has been given a grade for each of the three criteria, based on the discussion in Section 4.0 and the particular raw data the criteria is measured against (See Table 5-13). The raw values for the first criteria can be found in Table 5-3. Based on the scale discussed in Section 4.0, the following calculation can then be performed for each alternative to determine the score for the first criteria:

$$
\text { (350 days - unadjusted total processing days }) *(.05 \text { points/day) }=\text { Score }
$$

Figure 5-1 can be used to estimate the minimum availability factor needed to process all sludge in 350 days, or it can be calculated by dividing the unadjusted number of days by 350 days. This is then the raw value for the second criteria. Based on the range discussed in Section 4.0, the following calculation is then performed:

$$
(90 \% \text { - availability factor }) *(.25 \text { points } / \%)=\text { Score }
$$

As stated in section 4.0 the third criteria is much more subjective and requires more discussion since there is not any hard data to use as raw values. The first assumption made in determining the grades for the third criteria is that adding an additional dissolver will cost much more than adding an additional adjustment tank. An additional dissolver 
also increases the operational complexity much more than an additional adjustment tank would. Based on the factors discussed above, the following scale will be used to grade alternatives at this time:

Baseline (one of everything) $=\quad 10$ points

Additional Adjustment Tank $=-1.5$ points

Additional Dissolvers $\quad=\quad-3.0$ points

This scale may need changes if additional alternatives are analyzed in the future. The grades calculated using this scale can be found in Table 5-13.

The weighted point total is then calculated by multiplying each score by the weighting factor for that criteria.

Table 5-13 -- Time Diagram Decision Criteria Analysis Results

\begin{tabular}{|l|c|c|c|c|}
\hline Decision Criteria & $\begin{array}{l}\text { Criteria } \\
\text { Weighting }\end{array}$ & Alt. 1 & Alt. 2 & Alt. 3 \\
\hline $\begin{array}{l}\text { The amount of time the analyzed } \\
\text { alternative takes to complete processing } \\
\text { of all sludge. The measured value will } \\
\text { be the one that includes scheduled } \\
\text { cleanings, and is unadjusted for plant } \\
\text { availability. }\end{array}$ & $50 \%$ & $\begin{array}{c}2.4 \text { points } \\
(302.0 \text { days })\end{array}$ & $\begin{array}{c}4.4 \text { points } \\
(263.0 \text { days })\end{array}$ & $\begin{array}{c}6.6 \text { points } \\
(217.8 \text { days })\end{array}$ \\
\hline $\begin{array}{l}\text { The availability estimate required for } \\
\text { the analyzed alternative to achieve } \\
\text { compliance with criteria 1 (Process all } \\
\text { sludge in less than 350 days). }\end{array}$ & $30 \%$ & $\begin{array}{c}.9 \text { points } \\
(86.3 \%)\end{array}$ & $\begin{array}{c}3.7 \text { points } \\
(75.1 \%)\end{array}$ & $\begin{array}{c}6.9 \text { points } \\
(62.2 \%)\end{array}$ \\
\hline $\begin{array}{l}\text { The amount of duplicate equipment } \\
\text { required. }\end{array}$ & $20 \%$ & 8.5 points & 7 points & 4 points \\
\hline Weighted Point Total & & $\mathbf{3 . 1 7}$ & $\mathbf{4 . 7 1}$ & $\mathbf{6 . 1 7}$ \\
\hline
\end{tabular}

Alternative $1-2$ Adjustment Tank Alternative Alternative 2-3 Adjustment Tank Alternative Alternative 3 - 3 Adjustment Tank and 2 Dissolver Alternative

Alternative 3, the 3 Adjustment Tank and 2 Dissolver Alternative receives the highest score using the discussed point scales and weighting criteria. It is important to note that if priorities change, the criteria weights may change. Or additional alternatives or technical review might change the defined point scales. In either case, the weighted point total could see significant changes.

\subsection{Programmatic Risk Analysis}

When risk is considered, it is often a given that when enabling assumptions are made to allow definition of a process, programmatic risks are inherent with those assumptions. In the case of this time diagram study, the whole thing is based on a set of assumptions. For that reason, only a few of the most significant risks will be discussed. 
HNF-4516

Revision 0

\subsubsection{Sampling Turnaround and Adjustment Tank Risks}

The most significant assumption, in terms of time, is the assumption that overall sampling turnaround times will be 48 hours. This assumption on sampling could have great swings to both the good and bad. It is possible that if the right infrastructure were put in place, the turnaround time could be significantly reduced, maybe by more than half. However, it is much more likely that many times during the processing life of the proposed alternatives the sampling turnaround times will extend well beyond the 2 day period which has been assumed. Each delay in sampling turnaround, will be almost an hour for hour delay for the whole feed stream being processed. This will be especially critical when the adjustment tanks are the critical resource. Any discussion on reducing the number of required adjustment tanks should be evaluated against this risk, and cost effective improvements which could shorten the sampling turnaround time should be considered.

\subsubsection{Process Feed and Product Transportation Risks}

Another significant area of risk is in the transporting of both process feed and process products. At this time, neither multiple lag storage tanks for process feed, nor multiple storage tanks for neutralized product have been modeled. If the sludge removal and transport systems cannot supply sludge on demand, processing would be delayed whenever those systems failed to supply sludge. A related problem is that any increase in the number of lag storage tanks will require an increase in facility size, which may not have been accounted for. A similar and associated risk is that the time diagram models have only one neutralization tank that transfers directly into the transport system going to TWRS. If the transport system to TWRS is unable to keep up with demand, the process will face delays. All of these issues need to be integrated with the planned transportation studies.

\subsubsection{Sludge .Volume Risks}

If the volume and associated mass of sludge that requires processing is greater than the mean value used in the process flow sheets, none of the alternatives might support meeting the TPA constraint of retrieving and processing all $\mathrm{K}$ Basin sludge in 13 months. To truly put the project at risk, the increase would probably have to be greater than 10 percent, and maybe closer to 20 percent. From a programmatic standpoint, the 3 Adjustment Tank and 2 Dissolver alternative that received the highest weighted score would also withstand an increase in sludge volume the best.

\subsubsection{Conditioned Solids Settling Risks}

A significant risk is being introduced to the overall process by accumulating $50+\mathrm{m} 3$ of settled solids slurry in one tank, allowing the solids to settle for the purpose of decanting excess water, and then assuming the remaining slurry can be homogenized. Significant changes to grouting portion of the process flowsheet might be experienced if the settled 
solids can't readily be resuspended. The upside however, is that grouting activities may not have to be completed within the TPA mandated timeframe. If this is the case, the assumed risk value is greatly reduced because of reduced consequences.

\subsubsection{Other Risks}

There are a number of other less significant risks inherent in the assumptions made for this time diagram study. The first one is the risk that dissolution times will increase causing delays in processing. This risk is not particularly significant for an alternative with 2 dissolvers because the dissolver is the critical resource for only one feed stream, KW2. The dissolution time for KE1 for example, would have to more than triple before its dissolution time would begin to delay the process. If an alternative with one dissolver was chosen, the consequence of this risk would increase. The 3 Adjustment Tank alternative for example, has the dissolver as the critical resource for all 5 feed streams. Therefore, there would be a one for one increase between batch processing times and dissolution times.

The second risk is the potential for delays caused by greater flushing times for the centrifuge. The only time the centrifuge is the critical resource is when process feed stream KW1 is being processed by the 3 Adjustment Tank and 2 Dissolver alternative (the preferred alternative from section 5.5). However, for this same alternative, it would take an increase of more than 1 hour per flushing cycle or 3 hours per batch to effect the overall processing times of feed stream KE1. The other 3 feed streams would be unaffected by these changes.

The third risk comes from the amount of time assumed for the change out of a cartridge filter. It has been assumed that this process can take place in 12 hours (See Appendix A). Because the cartridge filter is in use for less than 1 hour per batch, a window of 16-35 hours is available for the change out process, depending on the feed stream and alternative being considered. If changes cause the typical change out time to go beyond the available window, a corresponding delay will take place once every four batches.

The fourth risk to be discussed also involves the cartridge filters. This time diagram study has assumed that the process for grouting cartridge filters can happen concurrently with the analyzed processes. This means the filters can either be safely stored until the end, then grouted at the same time the conditioned solids are being grouted, or the filters can be grouted in smaller groups while sludge is being processed. Either way, it has been assumed that the process of grouting cartridge filters will have no impact on the overall sludge processing times, and therefore the grouting of cartridge filters has not been analyzed. If some unforeseen restrictions eliminated the option of grouting cartridge filters while sludge is being processed, and a new interpretation of the TPA constraint required the grouting of cartridge filters be finished within the 13-month processing window, a 15-30 day addition to processing times could be realized. However, it is assumed that the likelihood of either event is very small. 
The fifth risk concerns the total mass of Uranium inside the facility and potentially affects any of the alternatives. If a mass limit for total Uranium allowed inside the facility at one time is imposed, it could restrict the optimization of batch start times. The masses of Uranium used in Table 5-14 can be found in Westra (1998). The total mass of Uranium in 6 batches can be compared to the minimum safe mass in a $\mathrm{UO}_{2}$ solution of $875 \mathrm{~kg}$ Uranium enriched up to $1.25 \%{ }^{235} \mathrm{U}$ as found in HNF-SD-SNF-CSER-009, Revision 1. While not strictly a criticality risk, there is a risk that mass limits may be imposed based on the criticality numbers. From Table 5-14 it can be seen that a significant mass of Uranium could be in the facility at one time when processing streams $\mathrm{KE} 2, \mathrm{KW} 1$, and $\mathrm{KW} 3$. This issue may require further study at a future time when the project is better defined.

Table 5-14 - Total Mass of Uranium in Facility

\begin{tabular}{|l|c|c|c|c|c|}
\hline & \multicolumn{5}{|c|}{ Feed Streams } \\
\hline $\begin{array}{l}\text { Maximum number of batches in } \\
\text { the facility at one time under } \\
\text { normal operating conditions (in } \\
\text { all cases the lag storage tank is } \\
\text { empty or almost empty) }\end{array}$ & 5 & 6 & 5 & 6 & 6 \\
\hline $\begin{array}{l}\text { Total mass Uranium per "160 kg } \\
\text { of solids" batch (kg) }\end{array}$ & 17.9 & 115.4 & 7.8 & 143.6 & 98.5 \\
\hline $\begin{array}{l}\text { Total mass Uranium in 6 batches } \\
\text { (kg) }\end{array}$ & 107.4 & 692.4 & 46.8 & 861.6 & 591.0 \\
\hline
\end{tabular}

The final risk discussed in this section deals with the commingling of multiple batch parts and products in the Resin Buffer Tank and the Solids Reception Tank. If events take place that preclude the project from collecting many batches worth of either the elutriation column light phase in the Resin Buffer Tank or the conditioned solids from the centrifuge in the Solids Reception Tank, the overall processing times could be significantly lengthened for the analyzed alternatives. However, it is assumed that the likelihood of either event is very small.

\subsection{Sensitivity Analysis}

The purpose of this section is to identify and discuss the significant sensitivity issues of each alternative. If a reasonable change to any assumption will cause a noticeable increase in processing time, that should be discussed here. It is also apparent that the most significant sensitivities will be those having an immediate effect on the processing of feed stream KE1 since it typically comprises more than $60 \%$ of the required processing days. It should also be noted that the deletion of processing steps, for example the removal of the resin separation step, can only decrease operating times when they affect a critical resource. Removing a processing step may shorten the total processing time for a single batch, but will only shorten the time between batch starts when the deleted step affects a critical resource. 
HNF-4516

Revision 0

\subsubsection{Sensitivities of 2 Adjustment Tank Alternative}

For feed streams KEl and KWl the adjustment tanks are the critical resources. Any increase in sampling turnaround time would be a one for one increase in total processing times for over $70 \%$ of the batches. It would take an increase of over 4 hours to affect any of the other feed streams. It is worth noting that a decrease in adjustment tank usage (i.e., sampling turnaround times) of up to 4 hours would decrease the time between batch starts for $\mathrm{KEl}$ on a one to one basis. This could mean a decrease of up to $12 \%$ in total unadjusted processing days.

For feed streams KE2, KW2 and KW3 the dissolver is the critical resource. Any increases in dissolution times would be a one for one increase in total processing times for over $25 \%$ of the batches. It would take a dissolution time increase of over 4 hours to affect either the KE1 or KW 1 feed streams.

For this alternative, those are the only resources susceptible to reasonable changes in their assumptions. It would take an increase of over 5 hours in centrifuging time, or a decrease of 5 hours for the adjustment tanks and 1 hour for the dissolver, to make centrifuging time an issue for stream KW1. This kind of increase in centrifuging time is possible for feed stream KW1 because of the high solids content, but KW1 only consists of 11.2 batches per the flowsheet. It would require an increase of over 12 hours in centrifuging time to impact the other feed streams.

\subsubsection{Sensitivities of 3 Adjustment Tank Alternative}

The dissolver is the critical resource for all 5 process feed streams. Any increases in dissolution times will have a direct, one to one, and effect. Conversely, any decrease in dissolver usage of up to 4 hours for KE1 and KW1 (even greater for the other feed streams), would also cause a direct, one to one, and decrease in time between batch starts.

The only other reasonable change that would affect this alternative would be an increase in centrifuging times for $\mathrm{KWI}$ of more than 3 hours per batch. However, since KWl consists of only 11.2 batches per the flowsheet, it would have little effect on the overall processing times.

\subsubsection{Sensitivities of 3 Adjustment Tank and 2 Dissolver Alternative}

The times between batch starts, for this alternative, have all been reduced from previous alternatives. Because of this, the number of potential sensitivity issues has increased. However, the most significant issues still involve adjustment tank usage and centrifuge/clarified liquid tank usage.

The adjustment tanks are the critical resource for $\mathrm{KE} 1, \mathrm{KE} 2$, and $\mathrm{KW} 3$. An increase in sampling turnaround times or other adjustment tank usage times would have a direct impact on total processing times, especially since these 3 feed streams comprise over $85 \%$ of the required processing days. The increase would have to be greater than 4 hours 
per batch to effect the processing times of KW1 and KW2. On the other hand, adjustment tank usage could be reduced by more than 4 hours per batch for KEl before the centrifuge/clarified liquid tank combination would approach critical resource status. The KE2 and KW3 feed streams could have adjustment tank usage reduced by 4 hours per batch before the dissolver became the critical resource. There would be no benefit for KW1, whose critical resource is already the centrifuge/clarified liquid tank combination, or KW2, whose critical resource is the dissolver.

An increase or decrease in dissolution times would only have direct impact on the processing of feed stream KW2. The dissolution time would have to increase by more than 4 hours to effect the processing of feed stream $\mathrm{KE} 2$, and 6-12 hours for any of the other feed streams.

This alternative is slightly more sensitive to centrifuge/clarified liquid tank assumption changes. While this resource is the critical resource for feed stream KW1 only, it would only take an increase of 3-4 hours per batch in centrifuge usage to start increasing the total processing time of feed stream KE1.

Finally, because the time between batch starts range from 17-19 hours for all feed streams, the assumed cartridge filter change out times could have an effect if found to be much longer than modeled. If the assumed filter change out time was increased from 12 hours to something greater than 17 hours the total processing time would increase. The increase would be the difference between the batch start time and newly greater filter change out time, once every four batches. It would take a five-hour increase to make any difference and an approximately 10-hour increase to extend the total processing time by 10 days. 


\subsection{CONCLUSIONS}

Tables 6-1 and 6-2 summarize the information discussed in previous sections. It is fairly evident that it will require at least 3 adjustment tanks and 2 dissolvers to provide a comfortable margin between required processing days and the TPA driven timeframe of 390 days. However, previous discussions also document the great affect things like dissolution time and sample turnaround time can have on these processing times. Further study might show the increased life-cycle cost of adding a second dissolver is great enough to make the increased schedule risks of having only one dissolver acceptable. But, given the current weighted criteria summarized in Table 6-3 and the emphasis on meeting the TPA schedule, it is recommended that 3 adjustment tanks and 2 dissolvers be the planning basis for a $\mathrm{K}$ Basin sludge chemical processing system.

Table 6-1 - Processing Days Including Scheduled Cleanings

\begin{tabular}{|c|c|c|c|}
\hline \multicolumn{5}{|c|}{ Adjusted for 70\% Availability } \\
\hline $\begin{array}{c}\text { Process Feed } \\
\text { Stream }\end{array}$ & $\begin{array}{c}\text { 2 Adjustment } \\
\text { Tanks } \\
\text { Alternative }\end{array}$ & $\begin{array}{c}\text { 3 Adjustment } \\
\text { Tanks } \\
\text { Alternative }\end{array}$ & $\begin{array}{c}\text { 3 Adj. Tanks } \\
\text { and 2 } \\
\text { Dissolvers } \\
\text { Alternative }\end{array}$ \\
\hline KE1 & 276.9 & 225.0 & 200.0 \\
\hline KE2 & 56.2 & 55.7 & 38.4 \\
\hline KW1 & 23.7 & 21.0 & 19.9 \\
\hline KW2 & 27.8 & 27.8 & 19.0 \\
\hline KW3 & 46.9 & 46.2 & 33.9 \\
\hline Total Days & $\mathbf{4 3 1 . 4}$ & $\mathbf{3 7 5 . 7}$ & $\mathbf{3 1 1 . 1}$ \\
\hline
\end{tabular}

Table 6-2 - Processing Days Without Scheduled Cleanings

\begin{tabular}{|c|c|c|c|}
\hline \multicolumn{4}{|c|}{ Adjusted for 60\% Availability } \\
\hline $\begin{array}{c}\text { Process Feed } \\
\text { Stream }\end{array}$ & $\begin{array}{c}\text { 2 Adjustment } \\
\text { Tanks } \\
\text { Alternative }\end{array}$ & $\begin{array}{c}\text { 3 Adjustment } \\
\text { Tanks } \\
\text { Alternative }\end{array}$ & $\begin{array}{c}\text { 3 Adj. Tanks } \\
\text { and 2 } \\
\text { Dissolvers } \\
\text { Alternative }\end{array}$ \\
\hline KE1 & 293.8 & 227.2 & 197.1 \\
\hline KE2 & 60.3 & 59.8 & 37.3 \\
\hline KW1 & 25.2 & 21.7 & 20.3 \\
\hline KW2 & 30.4 & 30.4 & 18.9 \\
\hline KW3 & 49.9 & 49.1 & 33.2 \\
\hline Total Days & $\mathbf{4 5 9 . 7}$ & $\mathbf{3 8 8 . 2}$ & $\mathbf{3 0 6 . 7}$ \\
\hline
\end{tabular}


HNF-4516

Revision 0

Table 6-3 -- Time Diagram Analysis Summary Results

\begin{tabular}{|l|c|c|c|c|}
\hline Decision Criteria & $\begin{array}{l}\text { Criteria } \\
\text { Weighting }\end{array}$ & Alt. $\mathbf{1}$ & Alt. $\mathbf{2}$ & Alt. $\mathbf{3}$ \\
\hline Total Processing Time & $50 \%$ & $\begin{array}{c}2.4 \text { points } \\
(302.0 \text { days })\end{array}$ & $\begin{array}{c}4.4 \text { points } \\
(263.0 \text { days })\end{array}$ & $\begin{array}{c}6.6 \text { points } \\
(217.8 \text { days })\end{array}$ \\
\hline $\begin{array}{l}\text { The availability estimate required to } \\
\text { process sludge in less than 350 days }\end{array}$ & $30 \%$ & $\begin{array}{c}9 \text { points } \\
(86.3 \%)\end{array}$ & $\begin{array}{c}3.7 \text { points } \\
(75.1 \%)\end{array}$ & $\begin{array}{c}6.9 \text { points } \\
(62.2 \%)\end{array}$ \\
\hline $\begin{array}{l}\text { The amount of duplicate equipment } \\
\text { required (cost and complexity) }\end{array}$ & $20 \%$ & 8.5 points & 7 points & 4 points \\
\hline Weighted Point Total & & $\mathbf{3 . 1 7}$ & $\mathbf{4 . 7 1}$ & $\mathbf{6 . 1 7}$ \\
\hline
\end{tabular}

Alternative $1-2$ Adjustment Tank Alternative Alternative 2-3 Adjustment Tank Alternative

Alternative 3 - 3 Adjustment Tank and 2 Dissolver Alternative 
HNF-4516

Revision 0

\subsection{REFERENCES}

Klimper, S. C., SNF Project Sludge Treatment System Process Flow Diagram, H-191170, Revision 0, Numatec Hanford Corporation, dated August 3, 1998.

Roblyer, S. P. and Nelson, J. V., Calculation of $1.25 \%{ }^{235}$ U Enriched $\mathrm{UO}_{2}$ Solution Safe Slab, Safe Cylinder Diameter, Minimum Safe Mass, and Ion Exchange Module for CVDF, HNF-SD-SNF-CSER-009, Revision 1, Fluor Daniel Northwest, Inc., Richland Washington, dated December 29, 1998.

Westra, A. G., Flament, T. A., and de Lamartinie, L., $K$ Basin Sludge Treatment Process Description, HNF-2735, Revision 0, Numatec Hanford Corporation, Richland, Washington, dated August 28, 1998. 
HNF-4516

Revision 0

\section{APPENDIX A}

COMPLETE LIST OF TIME DIAGRAM ASSUMPTIONS 
This appendix contains all the time related assumptions used to define the durations of the process steps found in the Microsoft Project time diagram models. The assumptions in Table A-l were made in terms of time to complete a process step. Except where noted these times have been applied to all $\mathbf{5}$ streams with no difference being made for slightly different volumes.

Table A-1 - Time Diagram Process Step Assumptions ( 9 pages)

\begin{tabular}{|c|c|}
\hline Process Step & Assumptions \\
\hline Store Process Feed & . \\
\hline Configure Receiving Station & -Can be done in 30 minutes \\
\hline Receive Sludge & $\begin{array}{l}\text {-Full feed batch received in one shipment } \\
\text {-Transferred in } 1 \text { hour } \\
\text {-Feed available from Sludge Removal any time it is needed }\end{array}$ \\
\hline Homogenize Feed & $\begin{array}{l}\text {-Can be adequately mixed within } 10 \text { minutes of completing } \\
\text { transfer }\end{array}$ \\
\hline Feed Screening Process & $\begin{array}{l}\text {-No process restrictions; All process feed sent to screen in } 1 \\
\text { hour }\end{array}$ \\
\hline \multicolumn{2}{|l|}{ Screen Process Feed } \\
\hline Screen Feed & $\begin{array}{l}\text {-Assume full batch is screened } \\
\text {-All feed screened and large pieces flushed to interim holding } \\
\text { tank in } 1 \text { hour }\end{array}$ \\
\hline Run Flush Water & -No flow or operational restrictions \\
\hline $\begin{array}{l}\text { Store and homogenize screened } \\
\text { particles in interim holding tank }\end{array}$ & $\begin{array}{l}\text {-Will store until screening is complete } \\
\text {-Assume screened particles consist of } 95 \% \text { of OIER and } 10 \% \\
\text { of all other solids }\end{array}$ \\
\hline Send Sludge to Sludge Buffer Tank & -No flow restrictions; Can be done as fast as feed is screened \\
\hline $\begin{array}{l}\text { Send Large Particles to Elutriation } \\
\text { Column }\end{array}$ & -This will start after screening is complete and will take 1 hour \\
\hline \multicolumn{2}{|l|}{ Elutriate Resins } \\
\hline Start Elutriation Column & $\begin{array}{l}\text {-Time required to establish regulated flow in column is } \\
\text { minimal, can start while feed is being screened, and does not } \\
\text { impact process }\end{array}$ \\
\hline Operate Elutriation Column & $\begin{array}{l}\text {-Elutriation column can accept all screened particles in } 45 \\
\text { minutes } \\
\text {-Elutriation column can finish separating light and heavy } \\
\text { phases within } 15 \text { minutes of receiving last screened particles, } \\
\text { and flow of elutriating fluid can be readily adjusted to } \\
\text { compensate for the stoppage of feed flow } \\
\text {-Total estimated operating time is } 1 \text { hour }\end{array}$ \\
\hline
\end{tabular}




\begin{tabular}{|c|c|}
\hline Light Phase to Resin Buffer Tank & $\begin{array}{l}\text {-No process restrictions; will happen for whatever duration the } \\
\text { elutriation column is operating } \\
-100 \% \text { of OIER which enters elutriation column will go to the } \\
\text { Resin Buffer Tank }\end{array}$ \\
\hline Heavy Phase to Resin Buffer Tank & $\begin{array}{l}\text {-This will take } 30 \text { additional minutes to complete after } \\
\text { elutriation column is shut down }\end{array}$ \\
\hline \multicolumn{2}{|l|}{ Store Sludge } \\
\hline $\begin{array}{l}\text { Receive Sludge From } \\
\text { Screening/Elutriation }\end{array}$ & $\begin{array}{l}\text {-No process restrictions; Can be safely accumulated at } \\
\text { whatever rate it is received from screening/elutriation }\end{array}$ \\
\hline Homogenize Sludge & $\begin{array}{l}\text {-Can finish this within } 10 \text { minutes of completing the transfers } \\
\text { into the Sludge Buffer Tank }\end{array}$ \\
\hline Transfer Sludge to Dissolver & $\begin{array}{l}\text {-Restricted by Dissolver; will take } 8 \text { hours to transfer batch } \\
\text { and empty the Sludge Buffer Tank }\end{array}$ \\
\hline \multicolumn{2}{|l|}{ Store Resin } \\
\hline $\begin{array}{l}\text { Receive Light Phase from Elutriation } \\
\text { Column }\end{array}$ & $\begin{array}{l}\text {-No process restrictions; Can be safely accumulated at } \\
\text { whatever rate it is received from screening/elutriation }\end{array}$ \\
\hline Store Resins & $\begin{array}{l}\text {-Will store up to } 10 \text { batches worth of light phase from the } \\
\text { Elutriation Column for KE1 (this is approximately } 108 \mathrm{~kg} \text { of } \\
\text { solids and } 514 \text { liters of slurry) before sending to the Leaching } \\
\text { Tank } \\
\text {-Will receive and store the light phase from all batches of KE2 } \\
\text { ( } 40.2 \mathrm{~kg} \text { solids, } 173 \text { liters of slurry) before sending to the } \\
\text { Leaching.Tank } \\
\text {-Will receive and store the light phase from all batches of } \\
\text { KW 1, KW2, and KW } 3 \text { together before sending to the } \\
\text { Leaching Tank (approximately } 42 \mathrm{~kg} \text { of solids) }\end{array}$ \\
\hline Homogenize Resins & -This will take 15 minutes, or less \\
\hline Transfer Resins to Leaching Tank & $\begin{array}{l}\text {-This can be done in } 30 \text { minutes } \\
\text {-Won't start until adequate amount of resins have been } \\
\text { accumulated and the Leaching Tank is done being used to } \\
\text { leach centrifuged dissolver products }\end{array}$ \\
\hline \multicolumn{2}{|l|}{ Dissolve Sludge } \\
\hline Receive Recycled Nitric Acid & -Less than 10 minutes will be allocated for this \\
\hline $\begin{array}{l}\text { Add Initial Reagents to Dissolver } \\
\text { (300-500 liters) }\end{array}$ & -Will do this in 30 minutes \\
\hline Start Agitator & -No process impacts \\
\hline Heat Dissolver Contents & -Assume 2 hours for this \\
\hline $\begin{array}{l}\text { Receive Sludge From Sludge Buffer } \\
\text { Tank }\end{array}$ & -This will be spread out over 8 hours for safety considerations \\
\hline
\end{tabular}




\begin{tabular}{|c|c|}
\hline $\begin{array}{l}\text { Complete Reaction (additional } \\
\text { reaction time required to complete } \\
\text { reaction after receiving all feed from } \\
\text { the Sludge Buffer Tank; dependent on } \\
\text { particle size and feed composition) }\end{array}$ & $\begin{array}{l}-\mathrm{KE} 1: 4 \text { hours } \\
-\mathrm{KE} 2: 16 \text { hours } \\
-\mathrm{KW} 1: 2 \text { hours } \\
\text {-KW2: } 20 \text { hours } \\
\text {-KW3: } 12 \text { hours }\end{array}$ \\
\hline Cool Dissolver Contents & -Approximately 2 hours will be necassary for adequate cooling \\
\hline $\begin{array}{l}\text { Transfer Dissolver Contents to } \\
\text { Centrifuge }\end{array}$ & $\begin{array}{l}\text {-Transfers will occur at } 1 \mathrm{~m}^{3} / \mathrm{hr} \\
\text {-A transfer will be paused for flushing/washing whenever } 18 \\
\mathrm{~kg} \text { of solids have been accumulated in the centrifuge (e.g., } \\
\text { there will be } 2 \text { intermittent flushings per batch for KE1 feed } \\
\text { and each flushing will take } 55 \text { minutes based on centrifuge } \\
\text { assumptions); therefore the total time to transfer a batch and } \\
\text { empty the dissolver is as follows: } \\
\text { KE1: } 233 \text { minutes ( } 2 \text { intermittent flushings) } \\
\mathrm{KE2}: 147 \text { minutes ( } 0 \text { intermittent flushings) } \\
\mathrm{KW}: 360 \text { minutes ( } 5 \text { intermittent flushings) } \\
\mathrm{KW} 2: 147 \text { minutes ( } 0 \text { intermittent flushings) } \\
\mathrm{KW} 3: 147 \text { minutes ( } 0 \text { intermittent flushings) }\end{array}$ \\
\hline \multicolumn{2}{|l|}{ Centrifuge Dissolver Slurry } \\
\hline Start Centrifuge & -No process impacts \\
\hline Clarify Dissolver Slurry & $\begin{array}{l}\text {-Dissolver slurry will be received at } 1 \mathrm{~m}^{3} / \mathrm{hr} \text {; based on this and } \\
\text { flushing/washing assumptions below, the total time to clarify a } \\
\text { batch of dissolver slurry is as follows: } \\
\text { KE1: } 283 \text { minutes ( } 3 \text { flushings total) } \\
\text { KE2: } 197 \text { minutes ( } 1 \text { flushing total) } \\
\text { KW1: } 410 \text { minutes ( } 6 \text { flushings total) } \\
\text { KW2: } 197 \text { minutes ( } 1 \text { flushing total) } \\
\text { KW3: } 197 \text { minutes ( } 1 \text { flushing total) }\end{array}$ \\
\hline $\begin{array}{l}\text { Transfer Liquids to Clarified Liquid } \\
\text { Tank }\end{array}$ & $\begin{array}{l}\text {-No process restrictions; can occur at whatever rate the } \\
\text { centrifuge produces clarified liquid }\end{array}$ \\
\hline $\begin{array}{l}\text { Stop Centrifuge When } 18 \mathrm{~kg} \text { of Solids } \\
\text { Retained in Bowl or Done Clarifying } \\
\text { Dissolver Slurry }\end{array}$ & $\begin{array}{l}\text {-Clarification will be paused for flushing/washing whenever } \\
18 \mathrm{~kg} \text { of solids have been accumulated in the centrifuge (e.g., } \\
\text { there will be } 3 \text { flushings total per batch for KE1 feed), minimal } \\
\text { time ( } 5 \text { minutes) needed to stop centrifuge and prepare for } \\
\text { flushing process }\end{array}$ \\
\hline Flush Solids Cake with Water & -Can do this in 5 minutes (60 liters) \\
\hline Homogenize Solids Cake and Water & -Can do this in 5 minutes \\
\hline Recentrifuge Homogenized Slurry & -Can do this in 10 minutes \\
\hline $\begin{array}{l}\text { Transfer Wash Liquids to Clarified } \\
\text { Liquid Tank }\end{array}$ & -No process restrictions \\
\hline Flush Solids Cake With Water & -Can do this in 5 minutes ( 60 liters) \\
\hline Homogenize Solids Cake and Water & -Can do this in 5 minutes \\
\hline
\end{tabular}




\begin{tabular}{|c|c|}
\hline $\begin{array}{l}\text { Transfer Centrifuged Dissolver Slurry } \\
\text { to Leaching Tank }\end{array}$ & -Can do this in 5 minutes \\
\hline Prepare Centrifuge for more feed & -Can do this in 5 minutes \\
\hline \multicolumn{2}{|l|}{ Leach Rinsed Dissolver Solids } \\
\hline Receive Centrifuged Dissolver Slurry & $\begin{array}{l}\text {-No process restrictions; will take } 5 \text { minutes each time based } \\
\text { on centrifuge assumption }\end{array}$ \\
\hline Add Leaching Reagents & -Can do this in 30 minutes \\
\hline Homogenize Slurry to Aid Leaching & -This will take 4 hours \\
\hline $\begin{array}{l}\text { Transfer Leached Dissolver Slurry to } \\
\text { Centrifuge }\end{array}$ & $\begin{array}{l}\text {-Transfers will occur at } 1 \mathrm{~m}^{3} / \mathrm{hr} \\
\text {-A transfer will be paused for flushing/washing if } 18 \mathrm{~kg} \text { of } \\
\text { solids have been accumulated in the centrifuge } \\
\text {-The total time to transfer a batch and empty the leaching tank } \\
\text { is as follows: } \\
\text { KE1: } 148 \text { minutes ( } 2 \text { intermittent flushings) } \\
\mathrm{KE} 2: 13.2 \text { minutes ( } 0 \text { intermittent flushings) } \\
\mathrm{KW} 1: 351 \text { minutes ( } 5 \text { intermittent flushings) } \\
\mathrm{KW}: 15 \text { minutes ( } 0 \text { intermittent flushings) } \\
\mathrm{KW} 3: 6.6 \text { minutes ( } 0 \text { intermittent flushings) }\end{array}$ \\
\hline \multicolumn{2}{|l|}{ Centrifuge Leached Dissolver Slurry } \\
\hline Start Centrifuge & -No process impacts \\
\hline $\begin{array}{l}\text { Clarify Leached Dissolver Slurry } \\
\text { from Leaching Tank }\end{array}$ & $\begin{array}{l}\text {-Leached Dissolver slurry will be received at } 1 \mathrm{~m}^{3} / \mathrm{hr} \text {; based on } \\
\text { this and flushing/washing assumptions below, the total time to } \\
\text { clarify a batch of leached dissolver slurry is as follows: } \\
\text { KE1: } 199 \text { minutes ( } 3 \text { flushings total) } \\
\text { KE2: } 65 \text { minutes ( } 1 \text { flushing total) } \\
\text { KW1: } 402 \text { minutes ( } 6 \text { flushings total) } \\
\text { KW2: } 66 \text { minutes ( } 1 \text { flushing total) } \\
\text { KW3: } 58 \text { minutes ( } 1 \text { flushing total) }\end{array}$ \\
\hline $\begin{array}{l}\text { Transfer Liquids to Clarified Liquid } \\
\text { Tank }\end{array}$ & $\begin{array}{l}\text {-No process restrictions; can occur at whatever rate the } \\
\text { centrifuge produces clarified liquid }\end{array}$ \\
\hline $\begin{array}{l}\text { Stop Centrifuge when } 18 \mathrm{~kg} \text { of Solids } \\
\text { Retained in Bowl or Done Clarifying } \\
\text { Leached Dissolver Slurry }\end{array}$ & $\begin{array}{l}\text {-Clarification will be paused for flushing/washing when } 18 \mathrm{~kg} \\
\text { of solids have been accumulated in the centrifuge, minimal } \\
\text { time ( } 5 \text { minutes) needed to stop centrifuge and prepare for } \\
\text { flushing process }\end{array}$ \\
\hline Flush Solids Cake with Water & -Can do this in 5 minutes (60 liters) \\
\hline Homogenize Solids Cake and Water & -Can do this in 5 minutes \\
\hline Recentrifuge Homogenized Slurry & -Can do this in 10 minutes \\
\hline $\begin{array}{l}\text { Transfer Wash Liquids to Clarified } \\
\text { Liquid Tank }\end{array}$ & -No process restrictions \\
\hline Flush Solids Cake With Water & -Can do this in 7 minutes ( 75 liters) \\
\hline
\end{tabular}




\begin{tabular}{|c|c|}
\hline Homogenize Solids Cake and Water & -Can do this in 5 minutes \\
\hline $\begin{array}{l}\text { Transfer Leached/Flushed Dissolver } \\
\text { Slurry to Solids Reception Tank }\end{array}$ & -Can do this in 5 minutes \\
\hline Prepare Centrifuge for more feed & -Can do this in 5 minutes \\
\hline \multicolumn{2}{|l|}{ Store Clarified Liquid } \\
\hline $\begin{array}{l}\text { Receive Clarified Dissolver Product } \\
\text { Liquids From Centrifuge }\end{array}$ & -No process restrictions \\
\hline $\begin{array}{l}\text { Receive Dissolver Product Wash } \\
\text { Liquids From Centrifuge }\end{array}$ & -No process restrictions \\
\hline $\begin{array}{l}\text { Receive Clarified Leached Dissolver } \\
\text { Solids Liquid From Centrifuge }\end{array}$ & -No process restrictions \\
\hline $\begin{array}{l}\text { Receive Leached Dissolver Solids } \\
\text { Wash Liquids From Centrifuge }\end{array}$ & -No process restrictions \\
\hline $\begin{array}{l}\text { Transfer Clarified Liquids to } \\
\text { Cartridge Filter }\end{array}$ & $\begin{array}{l}\text {-Time based on filter capacity of } 150 \text { liters } / \mathrm{min} \text {. } \\
\text {-Transfer time per batch is as follows: } \\
\text { KE1: } 28.4 \text { minutes } \\
\text { KE2: } 21.3 \text { minutes } \\
\text { KW1: } 36.1 \text { minutes } \\
\text { KW2: } 21.7 \text { minutes } \\
\text { KW3: } 20.0 \text { minutes }\end{array}$ \\
\hline \multicolumn{2}{|l|}{ Filter Clarified Liquid } \\
\hline $\begin{array}{l}\text { Process Clarified Liquid Through } \\
\text { Cartridge }\end{array}$ & $\begin{array}{l}\text {-Time based on filter capacity of } 150 \text { liters/min. } \\
\text {-Transfer time per batch is as follows: } \\
\text { KE1: } 28.4 \text { minutes } \\
\text { KE2: } 21.3 \text { minutes } \\
\text { KW }: 36.1 \text { minutes } \\
\text { KW2: } 21.7 \text { minutes } \\
\text { KW3: } 20.0 \text { minutes }\end{array}$ \\
\hline $\begin{array}{l}\text { Transfer Filtered Liquid to } \\
\text { Adjustment Tank }\end{array}$ & -No process restrictions \\
\hline Rinse Cartridge Filter & -Assume this will take 30 minutes \\
\hline Changeout Cartridge Filter & $\begin{array}{l}\text {-Only occurs once every } 4 \text { batches } \\
\text {-Assumed to take } 12 \text { hours }\end{array}$ \\
\hline $\begin{array}{l}\text { Send Used Cartridge Filter to Final } \\
\text { Conditioning }\end{array}$ & $\begin{array}{l}\text {-Transport causes no process restrictions } \\
\text {-Adequate used filter storage at final conditioning }\end{array}$ \\
\hline \multicolumn{2}{|l|}{ Adjust Filtered Liquid } \\
\hline Receive and Store Filtered Liquid & $\begin{array}{l}\text {-No process restrictions } \\
\text {-Will take same time that it takes to process liquid through } \\
\text { cartridge filter, plus the } 30 \text { minutes to receive the filter rinse } \\
\text { water }\end{array}$ \\
\hline
\end{tabular}




\begin{tabular}{|c|c|}
\hline Sample and wait for results & $\begin{array}{l}\text {-Depending on infrastructure, information needed, and } \\
\text { priorities this could take anywhere from } 5 \text { hours to } 10 \text { days } \\
\text {-Will assume } 2 \text { days for initial time diagram }\end{array}$ \\
\hline Add Adjustment Reagents & $\begin{array}{l}\text {-Time varies greatly depending on amount of adjustments } \\
\text { reagents needed; } 0 \text { - } 1300 \text { liters depending on the batch } \\
\text {-Will assume } 1 \text { hour needed to transfer maximum amount; } \\
\text { This assumes no safety considerations restrict flow rate } \\
\text {-If a small amount of reagents are necessary, it is assumed a } \\
\text { minimum of } 15 \text { minutes will be required for operational } \\
\text { requirements } \\
\text {-Following are the estimated times for each feed stream: } \\
\text { KE1: } 2 \text { liters, } 15 \text { minutes } \\
\text { KE2: } 1,010 \text { liters, } 48 \text { minutes } \\
\text { KW } 1: 1 \text { liter, } 15 \text { minutes } \\
\text { KW2: } 1,279 \text { liters, } 60 \text { minutes } \\
\text { KW3: } 1,121 \text { liters, } 53 \text { minutes }\end{array}$ \\
\hline Homogenize Adjusted Liquid & -Assumed to take 15 minutes \\
\hline $\begin{array}{l}\text { Transfer Adjusted Liquid to } \\
\text { Neutralization Tank }\end{array}$ & -Assume no flow restrictions and transfer can occur in 1 hour \\
\hline \multicolumn{2}{|l|}{ Neutralize Adjusted Liquid } \\
\hline Receive and Store Adjusted Liquid & -Assume no flow restrictions and transfer can occur in 1 hour \\
\hline Add Neutralization Reagents & $\begin{array}{l}\text {-Assume } 1 \text { hour, but could take longer due to safety } \\
\text { considerations and exothermic reaction }\end{array}$ \\
\hline $\begin{array}{l}\text { Homogenize and Cool Neutralized } \\
\text { Slurry }\end{array}$ & -Assume 2 hours \\
\hline $\begin{array}{l}\text { Sample Slurry to Confirm TWRS } \\
\text { Acceptability }\end{array}$ & -Assume this step is not necessary \\
\hline $\begin{array}{l}\text { Transfer Neutralized Slurry to } \\
\text { Transport System }\end{array}$ & $\begin{array}{l}\text {-Assume } 1.5 \text { hours; Could be impacted by location of facility, } \\
\text { and size and configuration of transfer system ( } 1-6 \text { trucks? } \\
\text { Pipeline? }\end{array}$ \\
\hline \multicolumn{2}{|l|}{$\begin{array}{l}\text { Transfer Neutralized Slurry to } \\
\text { TWRS }\end{array}$} \\
\hline Receive and Load Neutralized Slurry & -Transport system drives this, assume 1.5 hours for now \\
\hline Transport Slurry to Tank Farms & $\begin{array}{l}\text {-Assume round trip by tanker truck would take } 8 \text { hours; this } \\
\text { includes any steps necessary to ensure truck is back at the } \\
\text { facility and ready for reuse }\end{array}$ \\
\hline \multicolumn{2}{|l|}{ Leach Resin Buffer Tank Contents } \\
\hline $\begin{array}{l}\text { Receive Resin Slurry from Resin } \\
\text { Buffer Tank }\end{array}$ & $\begin{array}{l}\text {-Assume this can be done in } 30 \text { minutes } \\
\text {-Resins will only be leached when a sufficient mass of solids } \\
\text { has been collected in the Resin Buffer Tank; Assume once } \\
\text { every } 10 \text { batches for KE1, one time total for KE2, and one } \\
\text { time total for all of KW1, KW2, and KW } 3\end{array}$ \\
\hline
\end{tabular}




\begin{tabular}{|c|c|}
\hline Add Leaching Reagents & Can do this in 30 minutes \\
\hline $\begin{array}{l}\text { Homogenize Resin Slurry to Aid } \\
\text { Leaching }\end{array}$ & -Assume this will take 4 hours \\
\hline $\begin{array}{l}\text { Transfer Leached Resin Slurry to } \\
\text { Centrifuge }\end{array}$ & $\begin{array}{l}\text {-Transfers will occur at } 1 \mathrm{~m}^{3} / \mathrm{hr} \\
\text {-A transfer will be paused for flushing/washing if } 18 \mathrm{~kg} \text { of } \\
\text { solids have been accumulated in the centrifuge }\end{array}$ \\
\hline \multicolumn{2}{|l|}{ Centrifuge Leached Resin Slurry } \\
\hline Start Centrifuge & -No process impacts \\
\hline $\begin{array}{l}\text { Clarify Leached Resin Slurry from } \\
\text { Leaching Tank }\end{array}$ & -Feed will be received at $1 \mathrm{~m}^{3} / \mathrm{hr}$ \\
\hline $\begin{array}{l}\text { Transfer Liquids to Clarified Liquid } \\
\text { Tank }\end{array}$ & $\begin{array}{l}\text {-No process restrictions; can occur at whatever rate the } \\
\text { centrifuge produces clarified liquid }\end{array}$ \\
\hline $\begin{array}{l}\text { Stop Centrifuge When } 18 \mathrm{~kg} \text { of Solids } \\
\text { Retained in the Bowl or Done } \\
\text { Clarifying the Leached Resin Slurry }\end{array}$ & $\begin{array}{l}\text {-Clarification will be paused for flushing/washing when } 18 \mathrm{~kg} \\
\text { of solids have been accumulated in the centrifuge or if all feed } \\
\text { has been clarified, minimal time ( } 5 \text { minutes) needed to stop } \\
\text { centrifuge and prepare for flushing process }\end{array}$ \\
\hline Flush Solids Cake with Water & -Can do this in 5 minutes \\
\hline Homogenize Solids Cake and Water & -Can do this in 5 minutes \\
\hline Recentrifuge Homogenized Slurry & -Can do this in 10 minutes \\
\hline $\begin{array}{l}\text { Transfer Liquids to Clarified Liquid } \\
\text { Tank }\end{array}$ & -No process restrictions \\
\hline Flush Solids Cake With Water & -Can do this in 7 minutes \\
\hline Homogenize Solids Cake and Water & -Can do this in 5 minutes \\
\hline $\begin{array}{l}\text { Transfer Leached/Flushed Resin } \\
\text { Slurry to Solids Reception Tank }\end{array}$ & -Can do this in 5 minutes \\
\hline Prepare Centrifuge for more feed & -Can do this in 5 minutes \\
\hline \multicolumn{2}{|l|}{ Grout Treated Solids } \\
\hline \multicolumn{2}{|l|}{ STEPS TO TREAT EXCESS LIQUID } \\
\hline $\begin{array}{l}\text { Receive Leached/Flushed Dissolver } \\
\text { Slurry from Centrifuge }\end{array}$ & $\begin{array}{l}\text {-Assume the following: } \\
\text { KE1: } 3 \text { times per batch } \\
\text { KE2: } 1 \text { time per batch } \\
\text { KW1: } 6 \text { times per batch } \\
\text { KW2: } 1 \text { time per batch } \\
\text { KW3: } 1 \text { time per batch } \\
\text {-Assume } 20 \text { minutes each time }\end{array}$ \\
\hline
\end{tabular}




\begin{tabular}{|c|c|}
\hline $\begin{array}{l}\text { Receive Leached/Flushed Resin } \\
\text { Slurry from Centrifuge }\end{array}$ & $\begin{array}{l}\text {-Assume } 6 \text { times each time KE1 resin slurry is leached (once } \\
\text { every } 10 \text { batches), } 3 \text { times for KE2 resin slurry, and } 3 \text { times for } \\
\text { all KW resin slurry } \\
\text {-Assume } 20 \text { minutes each time }\end{array}$ \\
\hline Settle Solids in Solids Reception Tank & -Assume this requires 5 days after end of last addition \\
\hline $\begin{array}{l}\text { Decant Excess Liquid and Transfer to } \\
\text { Clarified Liquid Tank }\end{array}$ & $\begin{array}{l}\text {-This will require multiple transfers dependent on Clarified } \\
\text { Liquid Tank size; This exercise will assume } 6 \text { equal transfers } \\
\text { of } 5,527 \text { liter batches } \\
\text {-Assume each transfer takes } 1 \text { hour }\end{array}$ \\
\hline Filter Excess Liquid & -Assume 38 minutes per batch \\
\hline Adjust Filtered Excess Liquid & $\begin{array}{l}\text {-Assume } 48 \text { hours to sample and get results } \\
\text {-Assume no time for adding adjustment reagents since mass } \\
\text { balance indicates less than } 1 \text { liter per batch would be required } \\
\text {-Assume transfer to Neutralization Tank tanks } 1 \text { hour }\end{array}$ \\
\hline Neutralize Excess Liquid & $\begin{array}{l}\text {-Assume neutralization reagents can be added in } 15 \text { minutes } \\
\text {-Assume } 30 \text { minutes to homogenize and cool } \\
\text {-Assume } 1.5 \text { hours to transfer neutralized slurry to transport } \\
\text { system }\end{array}$ \\
\hline $\begin{array}{l}\text { Transport Neutralized Slurry to } \\
\text { TWRS }\end{array}$ & $\begin{array}{l}\text {-Assume } 1.5 \text { hours to load transport } \\
\text {-Assume } 8 \text { hours to make round trip to TWRS }\end{array}$ \\
\hline \multicolumn{2}{|l|}{ STEPS TO GROUT SLURRY } \\
\hline Homogenize Remaining Slurry & $\begin{array}{l}\text {-Assume this takes } 8 \text { hours } \\
\text {-Assume this will be done after decantation is complete }\end{array}$ \\
\hline Sample Slurry and Wait For Results & $\begin{array}{l}\text {-Assume this takes } 2 \text { days } \\
\text {-Assume this will be done after homogenization is complete }\end{array}$ \\
\hline Restart Homogenization System & $\begin{array}{l}\text {-Mixing system will be stopped for sampling, but restarted and } \\
\text { continuously run after that while each grout liner is filled; The } \\
\text { mixing systems will be run for at least } 2 \text { hours before } \\
\text { transferring slurry to a liner }\end{array}$ \\
\hline Transfer Slurry to Grout Liner & -Assume this transfer will happen in 1 hour \\
\hline Add Grout Formers & -Assume this will happen in 1 hour \\
\hline Cure Grout Product in Liner & -Assume 2 days for this \\
\hline Cap and Seal Grout Liner & -Assume 4 hours \\
\hline Load Grout Liner on Transport & -Assume 4 hours \\
\hline Transfer Grout to ERDF & -Assume 8 hours for round trip \\
\hline \multicolumn{2}{|l|}{ Grout Used Cartridge Filters } \\
\hline Receive Used Cartridge Filters & -Assume 1 filter every 4 batches \\
\hline Load Cartridge Filters in Drums & $\begin{array}{l}\text {-Assume } 1 \text { filter per drum, loaded when received; assume this } \\
\text { takes } 8 \text { hours }\end{array}$ \\
\hline
\end{tabular}




\begin{tabular}{|c|c|}
\hline Store Filters in Drums & $\begin{array}{l}\text {-Assume this can be done until all used filters have been } \\
\text { collected; storage restrictions might require that filters in } \\
\text { drums be grouted before all have been collected } \\
\text {-Assume } 49-70 \text { drums/filters will need stored; PFD indicates a } \\
\text { minimum of } 48.4 \text { filters will be used and the actual number } \\
\text { depends on when changeouts will be scheduled }\end{array}$ \\
\hline Prepare Grouting Matrix & -Preparation time 4 hours \\
\hline Grout Filters in Drums & $\begin{array}{l}-1 \text { hour per } 4 \text { drum set } \\
-3 \text { hours between sets to allow initial setting of grout (safer to } \\
\text { move) and provide time to move filled drums, and position } \\
\text { new set of non-filled drums }\end{array}$ \\
\hline Cure Grout Product in Drums & $\begin{array}{l}-24 \text { hours per } 4 \text { drum set } \\
\text {-Assume as many sets as needed can be stored for curing }\end{array}$ \\
\hline Cap and Seal Drums & -2 hours per 4 drum set \\
\hline Load Drums on Transport & -1 hour per 4 drum set \\
\hline Transfer Drums to ERDF or WIPP & $\begin{array}{l}\text {-Assume ERDF is acceptable disposal destination } \\
\text {-Assume } 8 \text { hours per } 4 \text { drum set for complete round trip } \\
\text { including any unloading and redeployment steps }\end{array}$ \\
\hline
\end{tabular}


HNF-4516

Revision 0

APPENDIX B

SUPPORT INFORMATION AND CALCULATION RESULTS FOR THE 2 ADJUSTMENT TANKS ALTERNATIVE 
HNF-4516

Revision 0

This appendix contains the complete set of Microsoft Project produced summary time diagrams for the 2 Adjustment Tanks Alternative. The summary time diagrams contain the summary process steps for 4 consecutive batches. They do not include the processing of elutriation column light phases, cleaning/maintenance activities, or the grouting processes. Following each summary time diagram is a listing of all process steps for one batch of the same feed stream, their duration and related steps (predecessors), and the particular resources being used during those steps. The summary time diagrams are figures B-1, B-3, B-5, B-7, and B-9. The detailed process step listings are figures B-2, B$4, \mathrm{~B}-6, \mathrm{~B}-8$, and B-10.

The information obtained from the Microsoft Project models is then summarized in Figure B-11. Figure B-11 contains the Microsoft Excel spreadsheet used for the 2 Adjustment Tanks Alternative calculations. The top part shows the information gathered from the models, and the middle and bottom parts are the result of the calculations described in Section 5.1 and replicated in Excel. 


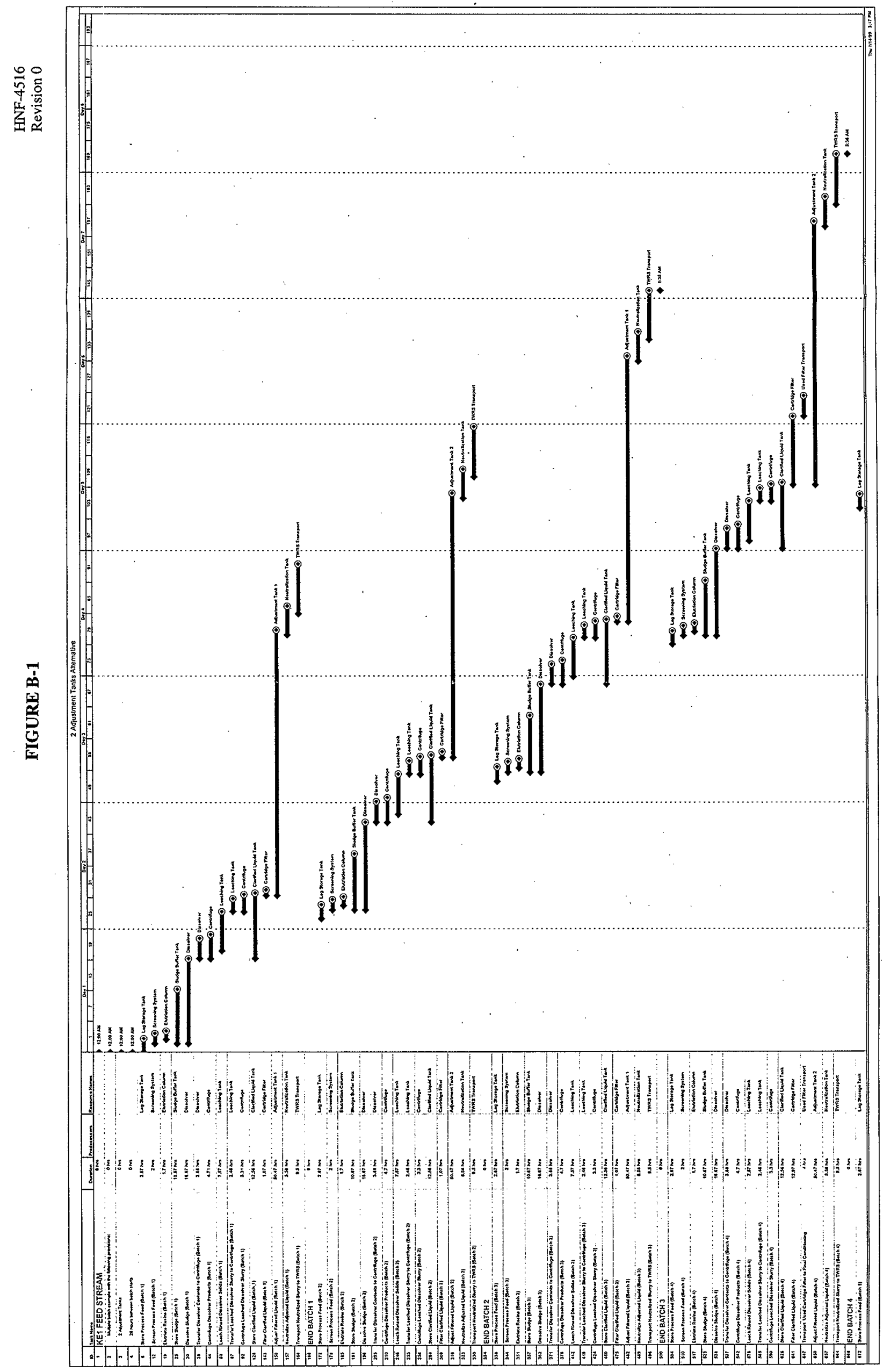


Figure B-2 - KE1 Process Steps for 2 Adjustment Tank Alternative

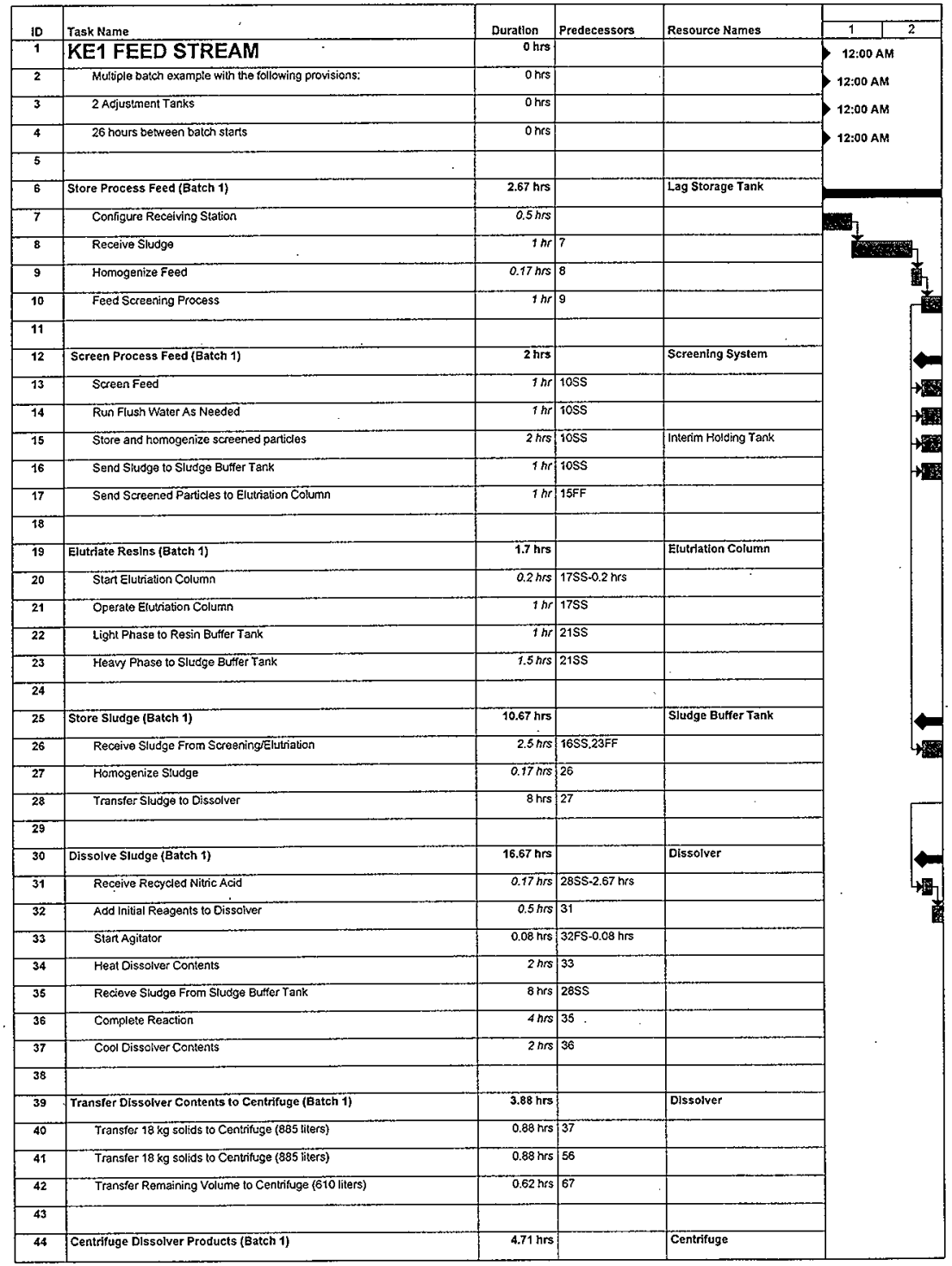


Figure B-2 -- KE1 Process Steps for 2 Adjustment Tank Alternative (cont.)

\begin{tabular}{|c|c|c|c|c|c|c|}
\hline 10 & Iask Name & Duration & Predecessors & Resource Names & 1 & 2 \\
\hline 45 & Start Centrifuge & $0.08 \mathrm{hrs}$ & 40 Ss -0.08 his & & \multirow{44}{*}{ 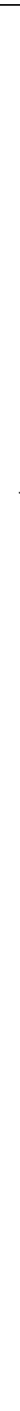 } & \\
\hline 46 & Clanty Feed From Dissolver & $0.88 \mathrm{hrs}$ & $40 \mathrm{sS}$ & & & \\
\hline 47 & Transfer Liquids to Clarfified Liquid Tank & $0.88 \mathrm{hrs}$ & $46 \mathrm{SS}$ & & & \\
\hline 48 & Stop Centrifuge When $18 \mathrm{~kg}$ of solids retained & $0.08 \mathrm{hrs}$ & 46 & & & \\
\hline 49 & Flush Solids Cake With Water (80 liters) & $0.08 \mathrm{hrs}$ & 48 & & & \\
\hline 50 & Homogenize Solids Cake and Water & $0.08 \mathrm{hrs}$ & 49 & & & \\
\hline 51 & Recentriftuge Homogenized S'urry & $0.17 \mathrm{hrs}$ & 50 & & & \\
\hline 52 & Transfer Liquids to Clañied Liquid Tank & $0.17 \mathrm{hrs}$ & 51SS & & & \\
\hline 53 & Fiush Solids Cake With Water (60 liters) & $0.08 \mathrm{hrs}$ & 52 & & & \\
\hline 54 & Homogenize Solids Cake and Water & $0.08 \mathrm{hrs}$ & 53 & & & \\
\hline 55 & Transfer Solution to Leaching Tank & $0.08 \mathrm{hrs}$ & 54 & & & \\
\hline 56 & Prepare Centrituge for more feed & $0.08 \mathrm{hrs}$ & 55 & & & \\
\hline 57 & Clarity Feed From Dissalver & $0.88 \mathrm{hrs}$ & 41ss & & & \\
\hline 58 & Transfer Liquids to Clanfied Liquid Tank & $0.88 \mathrm{hrs}$ & $57 \mathrm{SS}$ & & & \\
\hline 69 & Stop Centifuge When $18 \mathrm{~kg}$ of solids retained & $0.08 \mathrm{hrs}$ & 57 & & & \\
\hline 60 & Flush Sofids Cake With Water (60 titers) & $0.08 \mathrm{hrs}$ & 59 & & & \\
\hline 61 & Homogenize Solids Cake and Water & $0.08 \mathrm{hrs}$ & 60 & & & \\
\hline 62 & Recentrifuge Homogenized Slury & $0.17 \mathrm{hrs}$ & 61 & & & \\
\hline 63 & Transler Liquids to Clarified Liquidu Tank & $0.17 \mathrm{hrs}$ & $62 S S$ & & & \\
\hline 64 & Fiush Solids Cake Whth Water (60 liters) & $0.08 \mathrm{hrs}$ & 63 & & & \\
\hline 65 & Homogenize Solids Cake and Water & $0.08 \mathrm{hrs}$ & 64 & & & \\
\hline 66 & Transfer Solution to Leaching Tank & $0.08 \mathrm{hrs}$ & 65 & & & \\
\hline 67 & Prepare Centrítuge for moro feed & 0.08 hrs & 66 & & & \\
\hline 68 & Clarify Feed From Dissolver & $0.62 \mathrm{hrs}$ & $42 S s$ & & & \\
\hline 69 & Transter Liquids to Clanifed Liquid Tank & $0.62 \mathrm{hrs}$ & 685 & & & \\
\hline 70 & Stop Centrifuge When $18 \mathrm{~kg}$ of solids relained & $0.08 \mathrm{hrs}$ & 68 & & & \\
\hline 71 & Fiush Solids Cake With Water ( 60 liters) & $0.08 \mathrm{hrs}$ & 70 & & & \\
\hline 72 & Homogenize Solids Cake and Waler & $0.08 \mathrm{nrs}$ & 79 & & & \\
\hline 73 & Recentrifuge Homogenized Slurry & $0.17 \mathrm{hrs}$ & 72 & & & \\
\hline 74 & Transfer Liquids to Clarified Liquid Tank & $0.17 \mathrm{hrs}$ & $735 S$ & & & \\
\hline 75 & Flush Solids Cake With Water (60 liters) & $0.08 \mathrm{hrs}$ & 74 & & & \\
\hline 76 & Homogenize Solids Cake and Weler & $0.08 h \sigma_{0}$ & 75 & & & \\
\hline 77 & Transter Solution to Leaching Tank & $0.08 \mathrm{hrs}$ & 76 & & & \\
\hline 78 & Frepare Centrifuge for more feed & $0.08 \mathrm{nrs}$ & 77 & & & \\
\hline \multicolumn{5}{|l|}{79} & & \\
\hline 80 & Leach Rinsed Dissolver Sollds (Batch 1) & 7.57 hrs & & Leaching Tank & & \\
\hline 81 & Receive Centrifuged Dissolver SILIry & $0.08 \mathrm{hrs}$ & 5SSS & & & \\
\hline $\mathbf{8 2}$ & Receive Centrifuged Dissolver Silimy & 0.08 hrs & $665 S$ & & & \\
\hline 83 & Receive Centrifuged Dissolver Slumy & $0.08 \mathrm{~h} / \mathrm{s}$ & $77 S S$ & & & \\
\hline 84 & Add Leaching Reagents & $0.5 \mathrm{hrs}$ & 83 & & & \\
\hline 85 & Homogenize Slutry to Aid Leaching & 4 hrs & 84 & & & \\
\hline \multicolumn{5}{|l|}{86} & & \\
\hline 87 & Transfer Leached Dissolver Slumy to Centrifuge (Bateh 1) & $2.46 \mathrm{hrs}$ & & Leachlng Tank & & \\
\hline 88 & Transfer $18 \mathrm{~kg}$ solids to Centifuge (361 liters) & $0.37 \mathrm{hrs}$ & 85 & & & \\
\hline
\end{tabular}


Figure B-2 -- KE1 Process Steps for 2 Adjustment Tank Alternative (cont.)

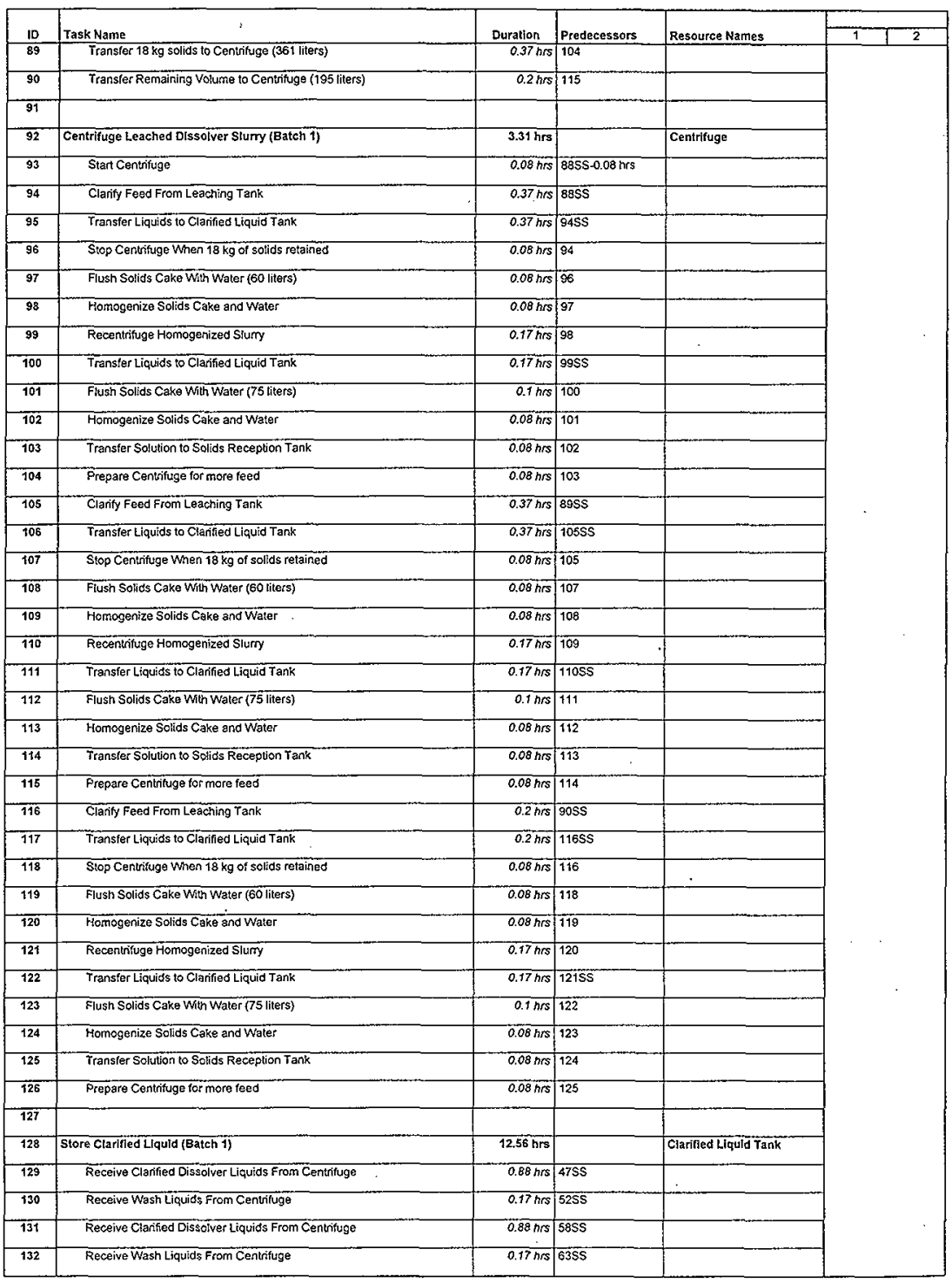


Figure B-2 -- KE1 Process Steps for 2 Adjustment Tank Alternative (cont.)

\begin{tabular}{|c|c|c|c|c|c|c|}
\hline & \multirow[b]{2}{*}{ Task Name } & \multirow[b]{2}{*}{ Duration } & \multirow[b]{2}{*}{ Predecessors } & \multirow[b]{2}{*}{ Resource Names } & \multirow{2}{*}{\multicolumn{2}{|c|}{\begin{tabular}{l|l|}
1 & 2 \\
\end{tabular}}} \\
\hline ID & & & & & & \\
\hline 133 & Receive Clanified Dissolver Liquids From Centrifuge & $0.62 \mathrm{hrs}$ & 69SS & & & \\
\hline 134 & Receive Wash Liquids From Centrifuge & $0.17 \mathrm{hrs}$ & $74 \$ 5$ & & & \\
\hline 135 & Receive Clanfied Leached Dissolver Slurry Licuids From Centriluge & $0.37 \mathrm{hrs}$ & 9555 & & & \\
\hline 136 & Receive Wash Liquids From Centriuge & $0.17 \mathrm{hrs}$ & $100 \$ s$ & & & \\
\hline 137 & Receive Clanfied Leached Dissoiver Slumy Liquids From Centriuge & $0.37 \mathrm{hrs}$ & $106 \mathrm{SS}$ & & & \\
\hline 138 & Receive Wash Liquids From Centrifuge & $0.17 \mathrm{hrs}$ & $111 \$ \$$ & & & \\
\hline 139 & Recelve Clanfied Leached Dissolver S|urry Liquids From Centrifuge & 0.2 hrs & $117 S S$ & & & \\
\hline 140 & Receive Wash Liquids From Centrifuge & $0.17 \mathrm{hrs}$ & $122 \mathrm{SS}$ & & & \\
\hline 141 & Transfer Clarifed Liquid to Cartridge Filter & $0.47 \mathrm{hrs}$ & $140 \mathrm{FS}+0.17 \mathrm{hrs}$ & & & \\
\hline \multicolumn{7}{|l|}{142} \\
\hline 143 & Filter Clarffied Liquid (Batch 1 ) & $1.07 \mathrm{hrs}$ & & Gartridge Filter & & \\
\hline 144 & Process Clanified Liquid Through Cartridge Filter & $0.47 \mathrm{hrs}$ & 14155 & & & \\
\hline 145 & Transier Filtered Liquid to Adjustment Tank & $0.47 \mathrm{hrs}$ & $144 S S$ & - & & \\
\hline 146 & Rinse Cartridge Filter & 0.5 his & 145 & & & \\
\hline 147 & Changeout Cartidge Filler & ohrs & $146 \mathrm{FS}+0.1 \mathrm{n} / \mathrm{s}$ & & & \\
\hline 148 & Send Used Cartridge Filler to Final Conditioning & Ohrs & 147 & & & \\
\hline \multicolumn{7}{|l|}{149} \\
\hline 150 & Adjust Filtered Liquid (Batch $t$ ) & $50.47 \mathrm{hrs}$ & & Adjustment Tank 1 & & \\
\hline 151 & Receive and Store Filtered Liquid & $0.97 \mathrm{hrs}$ & 14555 & & & \\
\hline 152 & Sample and Wait For Results & $48 \mathrm{hrs}$ & 151 & & & \\
\hline 153 & Add Adjustment Reagents ( $\sim 2$ liters) & $0.25 \mathrm{hrs}$ & 152 & & & \\
\hline 154 & Fomogenize Adjusted Liquid & $0.25 \mathrm{hrs}$ & 153 & & & \\
\hline 155 & Transier Adjusted Liquid to Neutralization Tank & $1 \mathrm{hr}$ & 154 & & & \\
\hline \multicolumn{7}{|l|}{156} \\
\hline 157 & Neutralize Adjusted Liquid (Batch 1) & $5.58 \mathrm{hrs}$ & & Neutralization Tank & & \\
\hline 158 & Receive and Store Adjusted Liquid & $1.08 \mathrm{hrs}$ & 15555 & & & \\
\hline 159 & Add Neutralization Reagents & ihr & 158 & & & \\
\hline 160 & Homogeṇize and Cool Neutralized Slumy & $2 h r$ & 159 & & & \\
\hline 161 & Sample Slumy to Confirm TWRS Acceptability & Ohrs & 160 & & & \\
\hline 162 & Transier Neutralized Sluny to Transpon System & $1.5 \mathrm{hrs}$ & 161 & & & \\
\hline \multicolumn{7}{|l|}{163} \\
\hline 164 & Transport Neutralized Slurry to TWRS (Batch i) & 9.5 hrs & & TWRS Transport & & \\
\hline 165 & Receive and Load Neutrelized Slusry & $1.5 \mathrm{hrs}$ & $162 S S$ & & & \\
\hline 166 & Transport Slurry to Tank Farms & $8 \mathrm{hrs}$ & 165 & & & \\
\hline \multicolumn{7}{|l|}{167} \\
\hline 168 & END BATCH 1 & o hrs & & & & \\
\hline 169 & This marks the end of batch 1 & on's & 166 & & & \\
\hline \multicolumn{7}{|l|}{170} \\
\hline \multicolumn{7}{|l|}{171} \\
\hline 172 & Store Process Feed (Batch 2) & 2.67 hrs & & Lag Storage Tank & & \\
\hline 173 & Configure Receiving Station & $0.5 \mathrm{hrs}$ & $7 S S+26 \mathrm{hrs}$ & & & \\
\hline 174 & Receive Sludge & $1 \mathrm{hr}$ & 173 & & & \\
\hline 175 & Homogenize Feed & $0.17 \mathrm{hrs}$ & 174 & & & \\
\hline 176 & Feed Screening Process & $1 \mathrm{hr}$ & 175 & & & \\
\hline
\end{tabular}




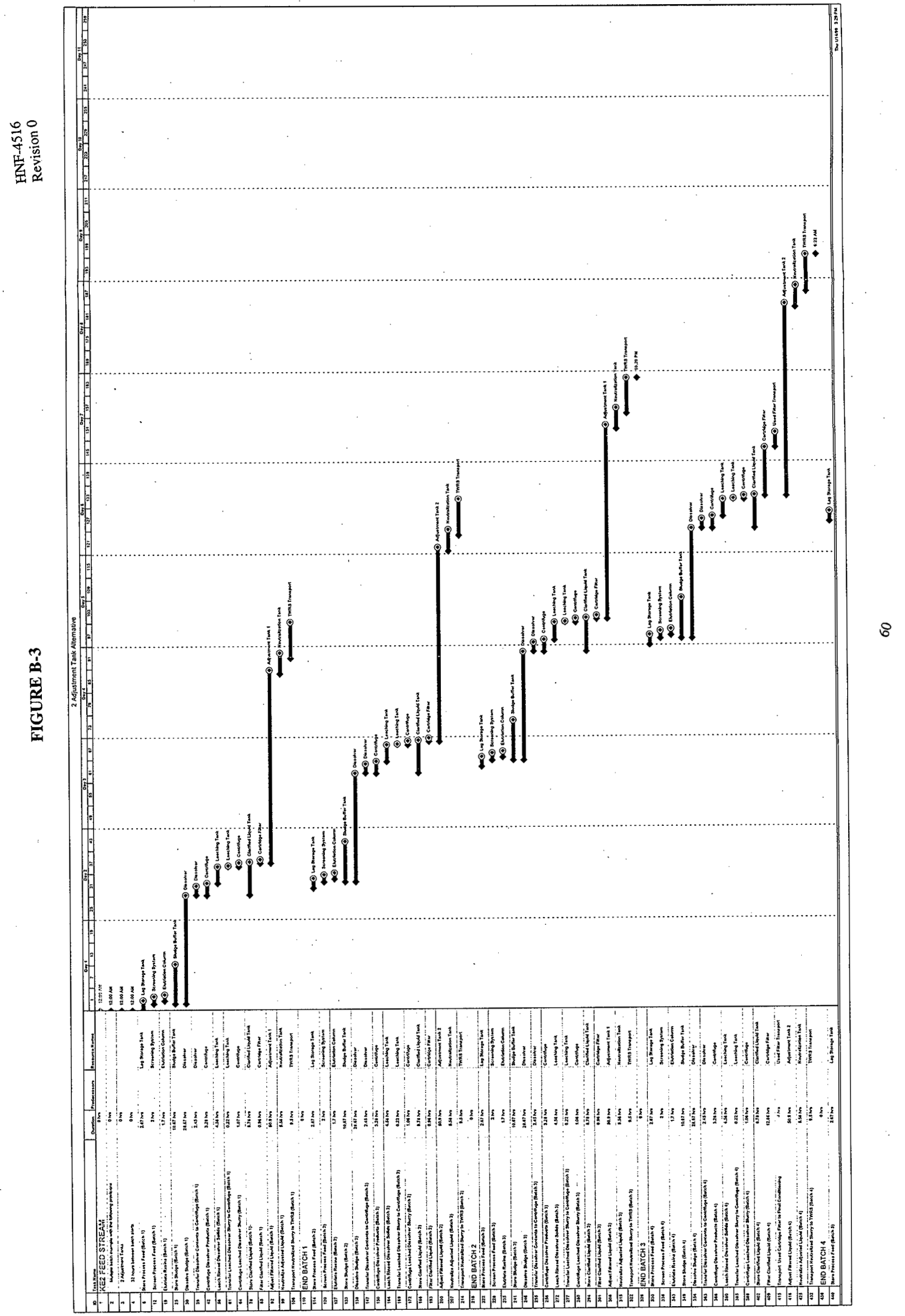


Figure B-4 -- KE2 Process Steps for 2 Adjustment Tank Alternative

\begin{tabular}{|c|c|c|c|c|}
\hline ID & Task Name & Duration & Predecessors & Resource Names \\
\hline 1 & KE2 FEED STREAM & o hrs & & \\
\hline 2 & Multiple batch example with the following provisions: & 0 his & & . \\
\hline 3 & 2 Adjustment Tanks & 0 hrs & & \\
\hline 4 & 32 hours between batch starts & ohrs & & \\
\hline \multicolumn{5}{|l|}{5} \\
\hline 6 & Store Process Feed (Batch 1) & $2.67 \mathrm{hrs}$ & & Lag Storage Tank \\
\hline 7 & Configure Receiving Station & $0.5 \mathrm{hrs}$ & & \\
\hline 8 & Receive Sludge & $1 \mathrm{hr}$ & 7 & \\
\hline 9 & Homogenize Feed & $0.17 \mathrm{hrs}$ & 8 & \\
\hline 10 & Feed Screening Process & $1 \mathrm{hr}$ & 9 & \\
\hline \multicolumn{5}{|l|}{11} \\
\hline 12 & Screen Process Feed (Batch I) & 2 hrs & & Screening System. \\
\hline 13 & Screen Feed & $7 \mathrm{hr}$ & $108 \mathrm{~S}$ & \\
\hline 14 & Run Flush Water As Needed & $1 \mathrm{hr}$ & $10 \$ \$$ & \\
\hline 15 & Store and homogenize screened particies & 2 hrs & $10 S s$ & Interim Holding Tank \\
\hline 16 & Send Sludge to Sludge Buffer Tank & $1 \mathrm{hr}$ & $10 \$ s$ & \\
\hline 17 & Send Screened Particles to Elutriation Column & $1 \mathrm{hr}$ & $15 F \mathrm{~F}$ & \\
\hline \multicolumn{5}{|l|}{18} \\
\hline 19 & Elutriate Resins (Batch 1) & $1.7 \mathrm{hrs}$ & & Elutriatlon Column \\
\hline 20 & Start Elutriation Column & $0.2 \mathrm{hrs}$ & 17 SS-0.2 hrs & \\
\hline 21 & Operate Elutriation Column & $1 \mathrm{hr}$ & 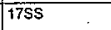 & \\
\hline 22 & Light Phase to Resin Buffer Tank & $1 \mathrm{hr}$ & 2155 & \\
\hline 23 & Heavy Phase to Studge Buffer Tank & $1.5 \mathrm{hrs}$ & $21 \$ S$ & \\
\hline \multicolumn{5}{|l|}{24} \\
\hline 25 & Store Siudge (Batch 1) & $10.67 \mathrm{hrs}$ & & Sludge Buffer Tank \\
\hline 26 & Receive Sludge From Screening/Elutriation & $2.5 \mathrm{hrs}$ & $16 \$ \$, 23 F F$ & \\
\hline 27 & Homogenize Sludge & $0.17 \mathrm{hrs}$ & 26 & \\
\hline 28 & Transfer Sludge to Dissolver & 8 hrs & 27 & \\
\hline \multicolumn{5}{|l|}{29} \\
\hline 30 & Dissolve sludge (Batch 1) & $28.67 \mathrm{hrs}$ & & Dissolver \\
\hline 31 & Receive Recycled Nitric Acid & $0.17 \mathrm{hrs}$ & $28 \mathrm{SS}-2,67 \mathrm{hrs}$ & \\
\hline 32 & Add Initial Reagents to Dissoiver & $0.5 \mathrm{hrs}$ & 31 & . \\
\hline 33 & Start Agitator & $0.08 \mathrm{hrs}$ & $32 \mathrm{FS}-0.08 \mathrm{hrs}$ & \\
\hline 34 & Heat Dissolver Contents & $2 \mathrm{hrs}$ & 33 & \\
\hline 35 & Recieve Sludge From Sludge Buffer Tank & $8 \mathrm{hrs}$ & $28 S S$ & \\
\hline 36 & Complete Reaction & $16 \mathrm{hrs}$ & 35 & \\
\hline 37 & Cool Dissolver Contents & $2 \mathrm{hrs}$ & 36 & \\
\hline \multicolumn{5}{|l|}{38} \\
\hline 39 & Transfer Dissolver Contents to Centrifuge (Batch 1) & $2.45 \mathrm{hrs}$ & & Dissolver \\
\hline
\end{tabular}


Figure B-4 -- KE2 Process Steps for 2 Adjustment Tank Alternative (cont.)

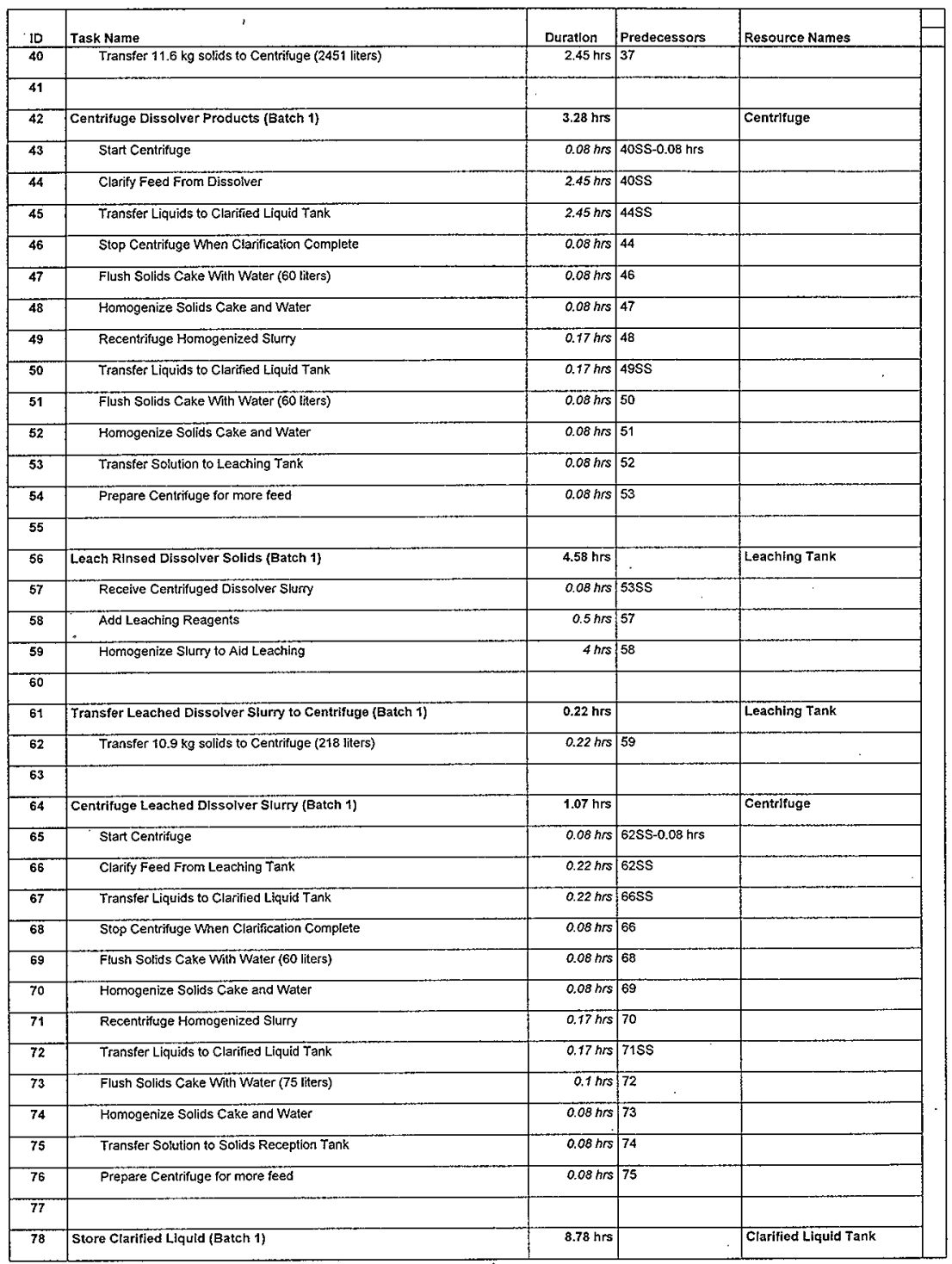


Figure B-4 -- KE2 Process Steps for 2 Adjustment Tank Alternative (cont.)

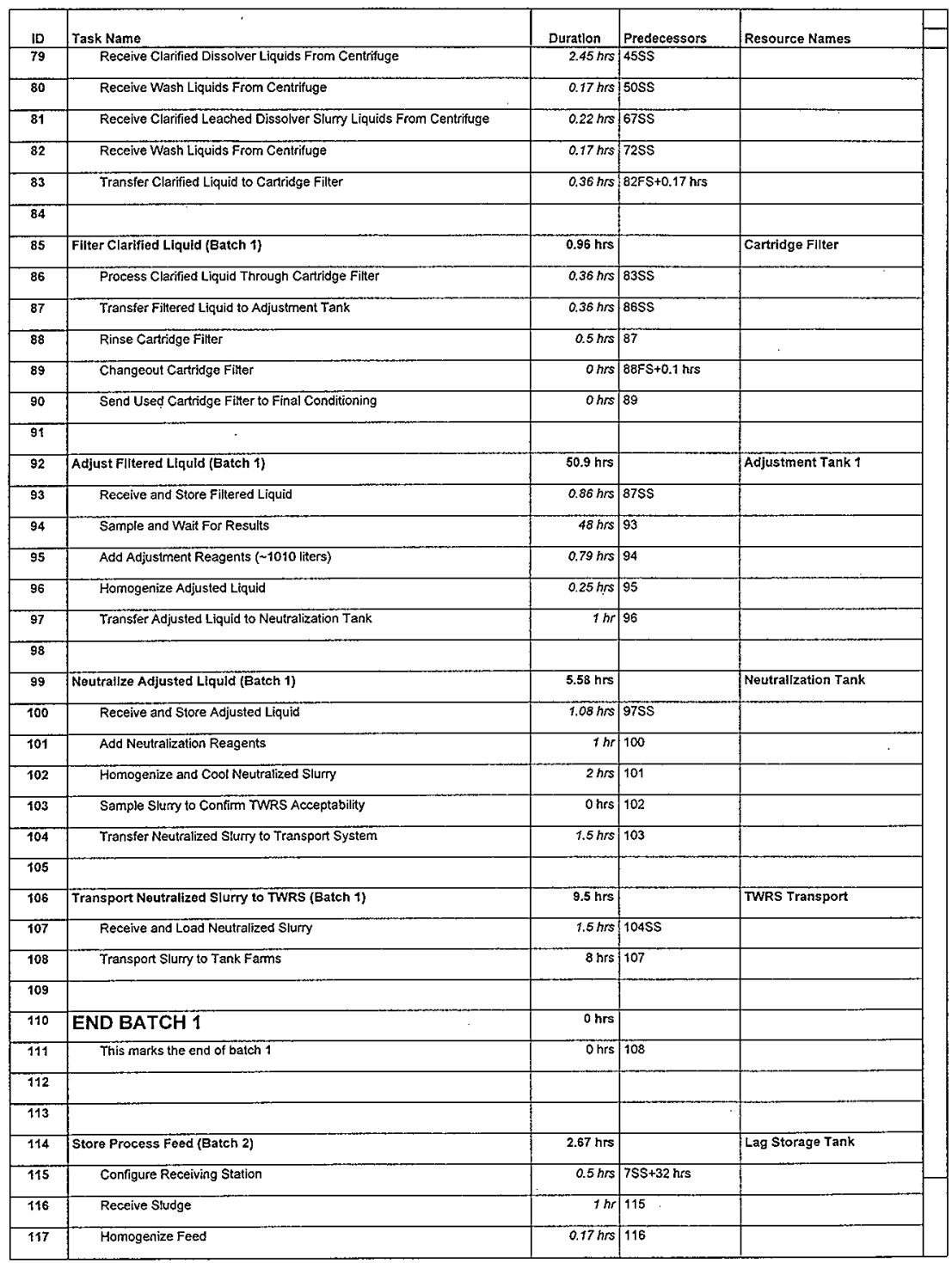




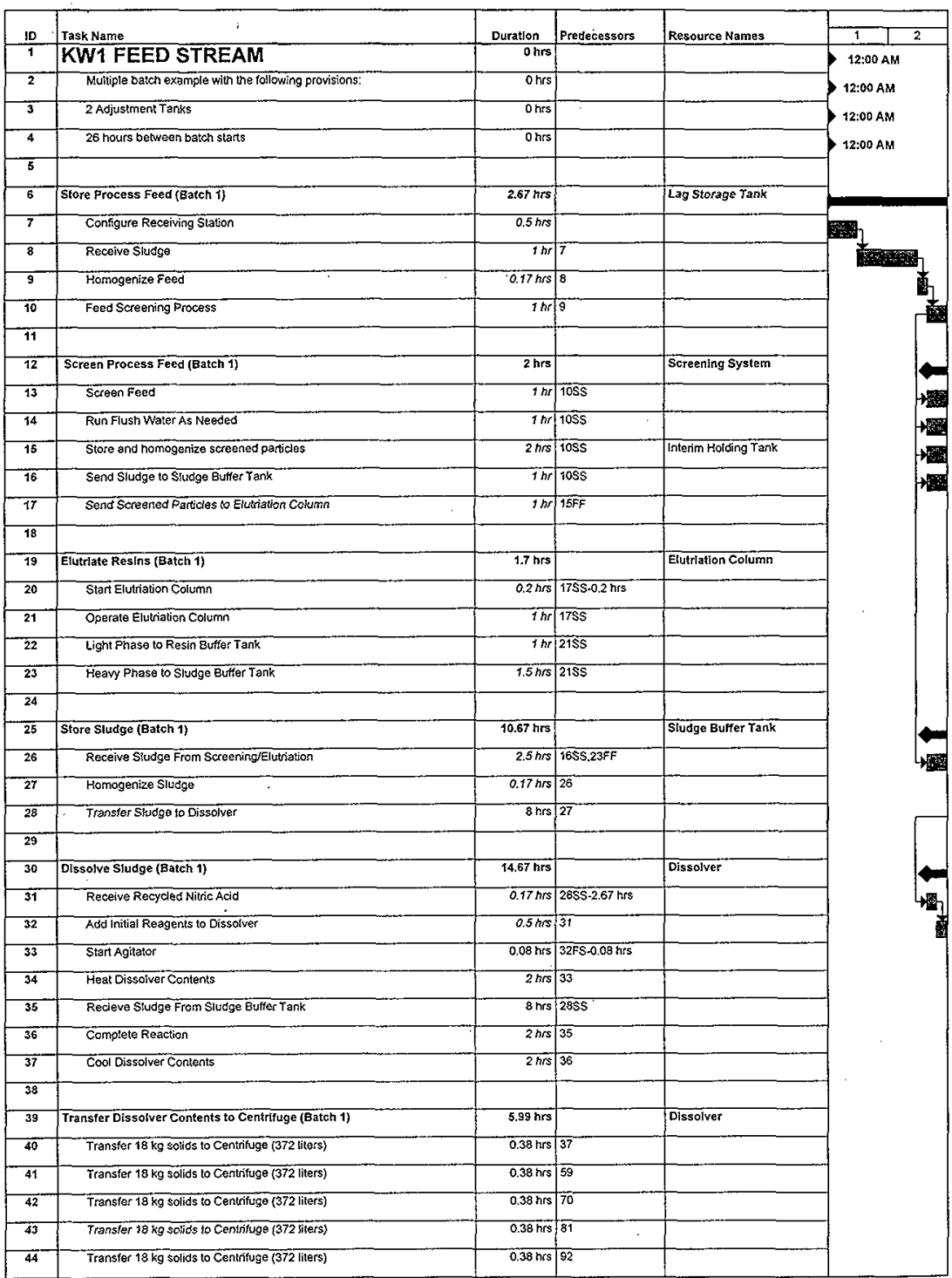


Figure B-6 - KW1 Process Steps for 2 Adjustment Tank Alternative (cont.)

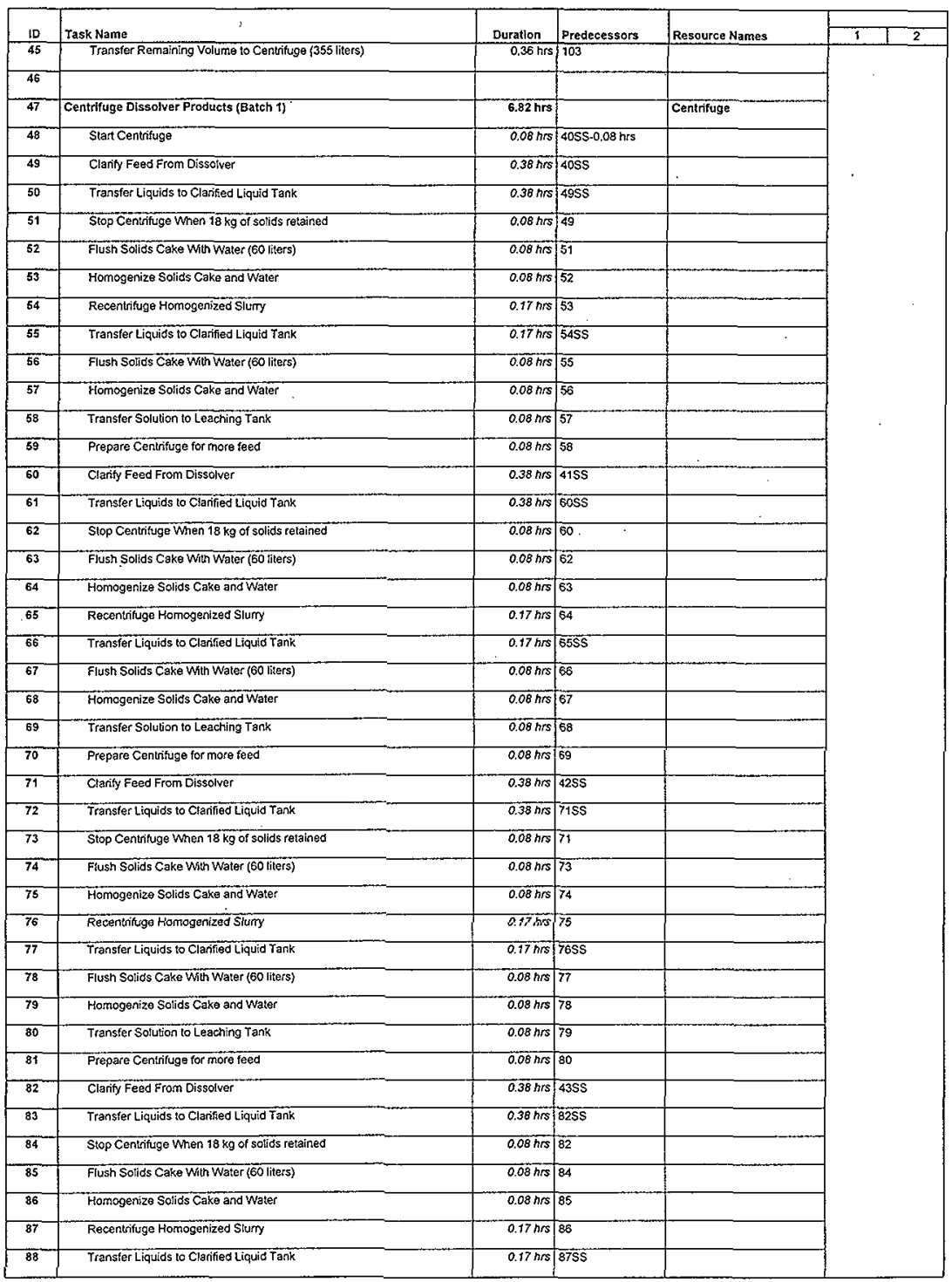


Figure B-6 -- KW1 Process Steps for 2 Adjustment Tank Alternative (cont.)

\begin{tabular}{|c|c|c|c|c|c|c|}
\hline \multirow[b]{2}{*}{ ID } & \multirow[b]{2}{*}{ Task Name } & \multirow[b]{2}{*}{ Duration } & \multirow[b]{2}{*}{ Predecessors } & \multirow[b]{2}{*}{ Resource Names } & \multirow[b]{2}{*}{1} & \multirow[b]{2}{*}{2} \\
\hline & & & & & & \\
\hline 89 & Flush Solids Cake With Water (60 liters) & $0.08 \mathrm{hrs}$ & 88 & & & \\
\hline 90 & Homogenize Solios Cake and Water & $0.08 \mathrm{hrs}$ & 89 & & & \\
\hline 91 & Transfer Solution to Leaching Tank & $0.08 \mathrm{hrs}$ & 90 & & & \\
\hline 92 & Prepare Centrifuge for more feed & $0.08 \mathrm{hss}$ & 91 & & & \\
\hline 93 & Clanty Feed From Oissolver & $0.38 \mathrm{hrs}$ & $44 S S$ & & & \\
\hline 94 & Transfer Liquids to Clanifed Liquid Tank & $0.38 \mathrm{hrs}$ & 93SS & & & \\
\hline 95 & Step Centrifuge When $18 \mathrm{~kg}$ of solids retained & $0.08 \mathrm{hrs}$ & 93 & & & \\
\hline 96 & Flush Sotios Cake Witn Water (60 iiters) & $0.08 \mathrm{hrs}$ & 95 & & & \\
\hline 97 & Homogenize Solids Cake and Water & $0.08 \mathrm{hrs}$ & 96 & & & \\
\hline 98 & Recontrituge Homogenized Siurry & $0.17 \mathrm{hrs}$ & 97 & & & \\
\hline 99 & Transfer Liquids lo Clarified Liquid Tank & $0.17 \mathrm{hrs}$ & $98 S 5$ & & & \\
\hline 900 & Flush Solids Cake With Water (60 liters) & $0.08 \mathrm{hrs}$ & 99 & & & \\
\hline$\overline{101}$ & Homogenize Solids Cake and Water & $0.08 \mathrm{hrs}$ & 100 & & & \\
\hline 102 & Transfer Solution to Leaching Tank & $0.08 \mathrm{hrs}$ & $10 t$ & & & \\
\hline 103 & Prepare Centrifuge for more feed & $0.08 \mathrm{hrs}$ & 102 & & & \\
\hline 104 & Clarify Feed From Dissolver & $0.36 \mathrm{hrs}$ & $45 S S$ & & & \\
\hline 405 & Transfer Liquioss to Clanified Liquid Tank & $0.36 \mathrm{hrs}$ & 104SS & & & \\
\hline 106 & Stop Centrifuge When $18 \mathrm{~kg}$ of solids retained & $0.08 \mathrm{hrs}$ & 104 & & & \\
\hline 107 & Flush Solids Cake With Water (60 liters) & $0.08 \mathrm{hrs}$ & 106 & & & \\
\hline 108 & Homogenize Solids Cake and Water & $0.08 \mathrm{hrs}$ & 107 & & & \\
\hline 109 & Recentrifuge Homogenized Slumy & $0.17 \mathrm{hrs}$ & 108 & & & . \\
\hline 110 & Transfer Liquids to Clanified Liquid Jank & 0.17 hrs & 10955 & & & \\
\hline 111 & Flush Solids Cake With Water (60 liters) & 0.08 hrs & 110 & & & \\
\hline 112 & Homogenize Solids Cake and Water & $0.08 \mathrm{hrs}$ & 111 & & & \\
\hline 113 & Transfer Solution to Leaching Tank & $0.08 \mathrm{hrs}$ & 112 & & & \\
\hline 714 & Prepare Centrifuge for more leed & $0.08 \mathrm{hrs}$ & 113 & & & \\
\hline \multicolumn{5}{|l|}{115} & & \\
\hline 116 & Leach RInsed Dissolver Solids (Batch 1) & $10.19 \mathrm{hrs}$ & & Leachlng Tank & & \\
\hline 117 & Receive Centrifuged Dissolver Slumy & $0.08 \mathrm{hrs}$ & $58 S S$ & & & \\
\hline 118 & Receiva Centrifuged Dissolver Slumy & $0.08 \mathrm{hrs}$ & $69 \$$ & & & \\
\hline t19 & Receive Centifuged Dissotver Slumy & $0.08 \mathrm{hrs}$ & $805 S$ & & & \\
\hline 720 & Receive Centrifuged Dissolver Slumy & $0.08 \mathrm{hrs}$ & $91 S \$$ & & & \\
\hline 121. & Receive Centrituged Dissolver Slumy & $0.08 \mathrm{hrs}$ & $1025 s$ & & & \\
\hline 122 & Receive Centrituged Dissolver Stury & $0.08 \mathrm{hrs}$ & $1135 S$ & & & \\
\hline 123 & Add Leaching Reagents & $0.5 \mathrm{hrs}$ & 122 & & & \\
\hline 124 & Homogenize slumy to Aid Leaching & $4 \mathrm{nrs}$ & 123 & & & \\
\hline \multicolumn{5}{|l|}{125} & & \\
\hline 126 & Transfer Leached Diss olver Slumy to Centrifuge (gatch 1) & 5.85 hrs & & Leaching Tank & & \\
\hline 127 & Transfer $18 \mathrm{~kg}$ solids to Centifugs ( 360 liters) & $0.36 \mathrm{hrs}$ & 124 & & & \\
\hline 128 & Transfer $18 \mathrm{~kg}$ solids to Centrifuge (360 liters) & 0.36 hrs & 146 & & & \\
\hline 129 & Transter $18 \mathrm{~kg}$ solids to Centrifuge (360 liters) & $0.36 \mathrm{hrs}$ & 157 & & & \\
\hline 130 & Transfer $18 \mathrm{~kg}$ solids to Cenlnifuge (360 liters) & $0.36 \mathrm{hrs}$ & 168 & & & \\
\hline 131 & Transfer $18 \mathrm{~kg}$ solids to Cenlnifuge ( 360 liters) & $0.36 \mathrm{hrs}$ & 179 & & & \\
\hline 132 & Transfer Remaining Volume to Centifuge (228 liters) & $0.23 \mathrm{hrs}$ & 190 & & & \\
\hline
\end{tabular}


Figure B-6 - KW1 Process Steps for 2 Adjustment Tank Alternative (cont.)

\begin{tabular}{|c|c|c|c|c|c|c|}
\hline ID & Task Name. & Duration & Predecessors & Resource Names & 1 & 2 \\
\hline \multicolumn{7}{|c|}{ 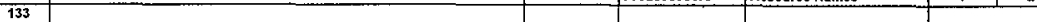 } \\
\hline 134 & Centrfuge Leached Dlssolver Slumy (Batch $t)$ & $6.59 \mathrm{hrs}$ & & Centrifuge & & \\
\hline 135 & Start Centrifuge & $0.08 \mathrm{hrs}$ & $127 \mathrm{SS}-0.08 \mathrm{hrs}$ & & & \\
\hline 136 & Clarify Feed From Leaching Tank & $0.36 \mathrm{hrs}$ & $127 \$ \$$ & & & \\
\hline 137 & Transfer Liquids to Clarifed Liquid Tank & $0.36 \mathrm{hrs}$ & $136 \mathrm{SS}$ & & & \\
\hline 138 & Stop Centrifuge When $18 \mathrm{~kg}$ of solids retained & $0.08 \mathrm{hrs}$ & 136 & & & \\
\hline 139 & Flush Solids Cake Whi Water (60 liters) & $0.08 \mathrm{hrs}$ & 138 & & & \\
\hline 140 & Homogenize Solids Cake and Water & $0.08 \mathrm{hrs}$ & 139 & & & \\
\hline 141 & Recentrifuge Homogenized Siumy & 0.7 hrs & 140 & & & \\
\hline 142 & Transfer Liquids to Clarifed Liquid Tank & $0.17 \mathrm{hrs}$ & $141 S 5$ & & & \\
\hline 143 & Flush Solids Cake With Water (75 tilers) & $0.1 \mathrm{hrs}$ & 142 & & & \\
\hline 144 & Homogenize Solids Cake and Water & $0.08 \mathrm{hrs}$ & 143 & & & \\
\hline 145 & Transfer Solution to Solids Reception Tank & $0.08 \mathrm{hrs}$ & 144 & & & \\
\hline 146 & Prepare Centrifuge for more feed & $0.0 \mathrm{ahrs}$ & 145 & & & \\
\hline 147 & Clarity Feed From Leaching Tank & $0.36 \mathrm{hrs}$ & $1285 S$ & & . & \\
\hline 148 & Transler Liquids to Clarified Liquid Tank & $0.36 \mathrm{hrs}$ & $147 S S$ & & & \\
\hline 149 & Stop Centrifuge When $18 \mathrm{~kg}$ of solids retained & $0.08 \mathrm{nrs}$ & 147 & & & \\
\hline 150 & Flush Solids Cake With Water (60 liters) & $0.08 \mathrm{hrs}$ & 149 & & & \\
\hline 151 & Homogenize Solids Cake and Water & $0.08 \mathrm{hrs}$ & 150 & & & \\
\hline 152 & Recentrifuge Homogenized Slury & 0.17 hrs & 151 & & & \\
\hline 153 & Transfer Liquids to Claôfied Liquid Tank & 0.17 hrs & \begin{tabular}{|l|}
$152 S S$ \\
\end{tabular} & & & \\
\hline 154 & Flush Solids Cake With Water (75 liters) & $0,1 \mathrm{hrs}$ & 153 & & & \\
\hline 155 & Homogenize Solids Cake and Water & $0.06 \mathrm{hrs}$ & 154 & & & \\
\hline 156 & Transfer Solutien to Solios Reception Tank & $0.08 \mathrm{hrs}$ & 165 & & & \\
\hline 157 & Prepare Centrifuge for more feed & $0.08 \mathrm{hrs}$ & 156 & & & \\
\hline 158 & Clarify feed From Leaching Tank & $0.36 \mathrm{hrs}$ & $1295 S$ & & & \\
\hline $15 \dot{9}$ & Transier Liquids to Clarified Liquid Tank & & 158 SS & & & \\
\hline 160 & Stop Centrifuge When $18 \mathrm{~kg}$ of solicis retained & $0.08 \mathrm{hrs}$ & 158 & & & \\
\hline 161 & Flush Solids Cake With Water (60 liters) & $0.08 \mathrm{hrs}$ & 160 & & & \\
\hline 162 & Homogenize Solids Cake and Water & $0.08 \mathrm{hrs}$ & $\overline{161}$ & & & \\
\hline 163 & Recentrituge Hornogenized Slumy & $0.17 \mathrm{hrs}$ & 162 & & & \\
\hline 164 & Transier Liquids to Clabited Liquid Tank & $0.17 \mathrm{hrs}$ & 16358 & & & \\
\hline 165 & Flush Solids Cake With Water (75 liters) & $0.1 \mathrm{hrs}$ & 164 & & & \\
\hline 166 & Homogenize Solids Cake and Water & $0.08 \mathrm{hrs}$ & 165 & & & \\
\hline 167 & Transfer Solution to Solids Reception Tank & $0.08 \mathrm{hrs}$ & 160 & & & \\
\hline 168 & Prepare Centrifuge for more teed & $0.08 \mathrm{hrs}$ & 167 & & & \\
\hline 169 & Clanify Feed From Leaching Tank & $0.36 \mathrm{hrs}$ & 130 S5 & & & \\
\hline 170 & Transfer Liquids to Clanified Liquid Tank & $0.36 \mathrm{hrs}$ & $1695 S$ & & & \\
\hline 171 & Stop Cenisfuge When $18 \mathrm{~kg}$ of soliss retained & $0.08 \mathrm{hrs}$ & 169 & & & \\
\hline 172 & Flush Solios Cake With Water (60 liters) & $0.08 \mathrm{hrs}$ & 171 & & & \\
\hline 173 & Homogenize Solids Cake and water & $0.08 \mathrm{hrs}$ & 172 & & & \\
\hline 174 & Recentrifuge Homogenized Slury & $0.17 \mathrm{~h} / \mathrm{s}$ & 173 & & & \\
\hline 175 & Transfer Liquids to Clarified Liquid Tank & $0.17 \mathrm{hrs}$ & 174 SS & & & \\
\hline 176 & Flush Solids Cake With Water (75 liters) & $0.1 \mathrm{~h} / \mathrm{s}$ & 175 & & & \\
\hline
\end{tabular}


Figure B-6 - KW1 Process Steps for 2 Adjustment Tank Alternative (cont.)

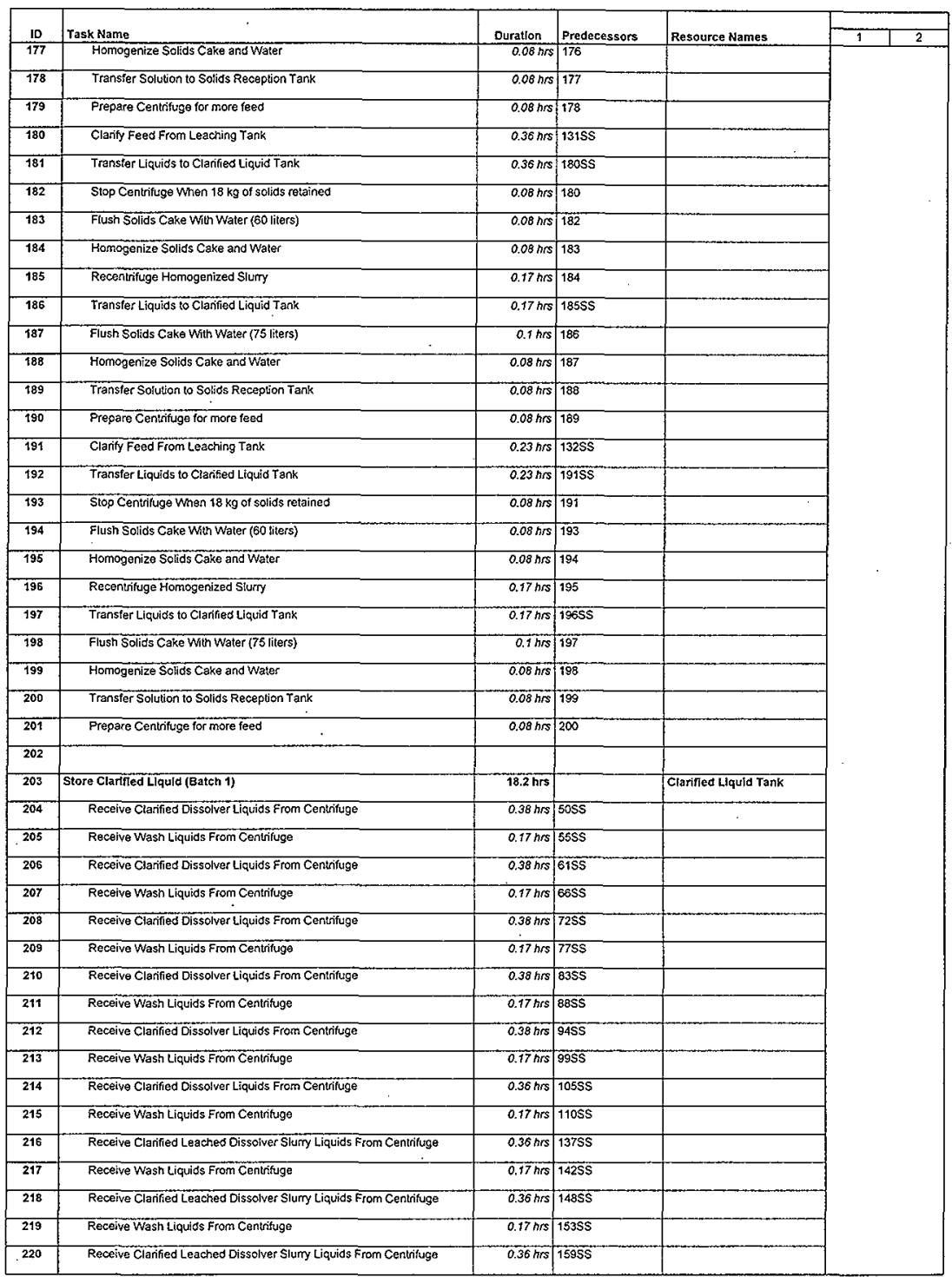


Figure B-6 -- KW1 Process Steps for 2 Adjustment Tank Alternative (cont.)

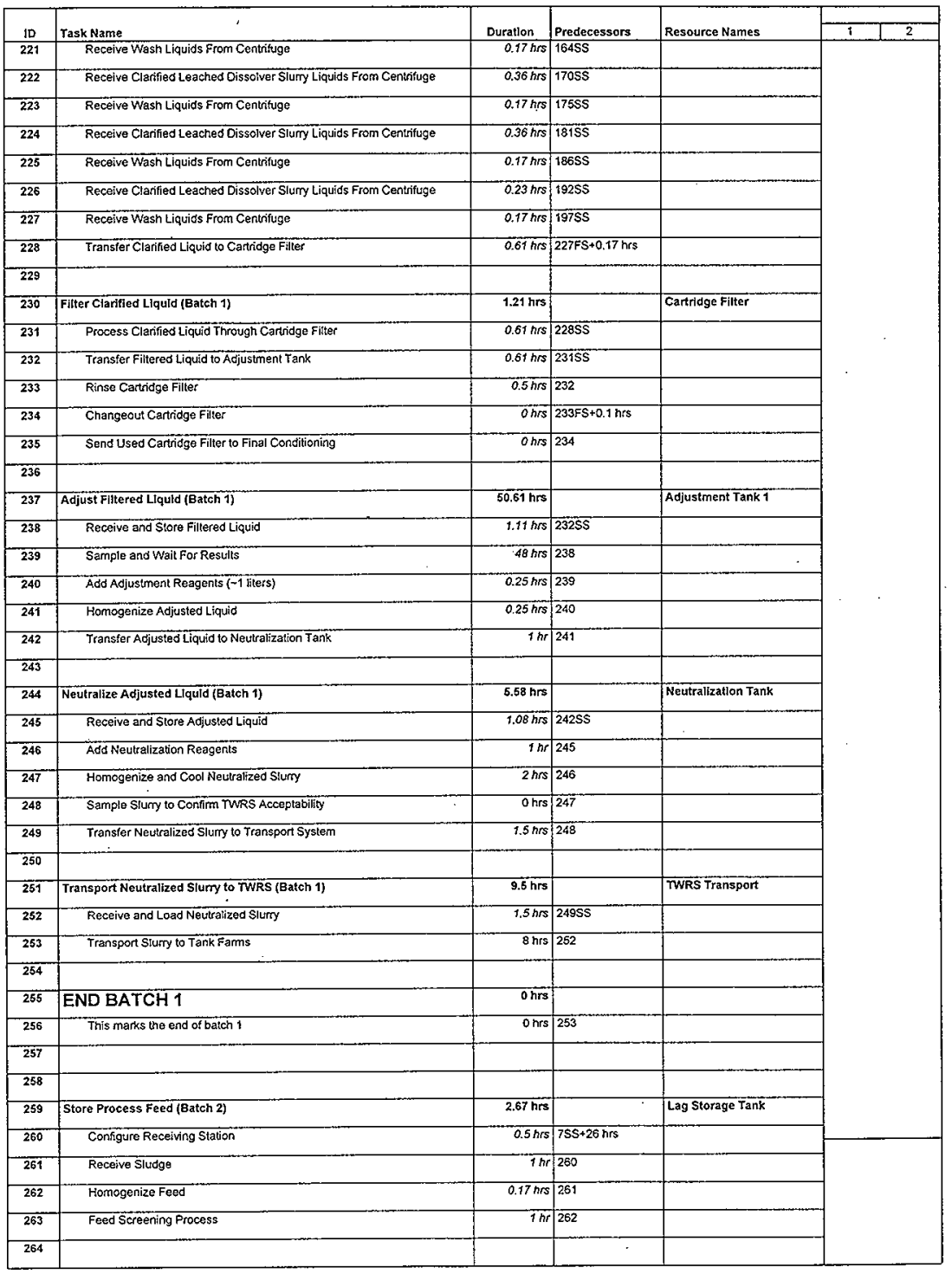




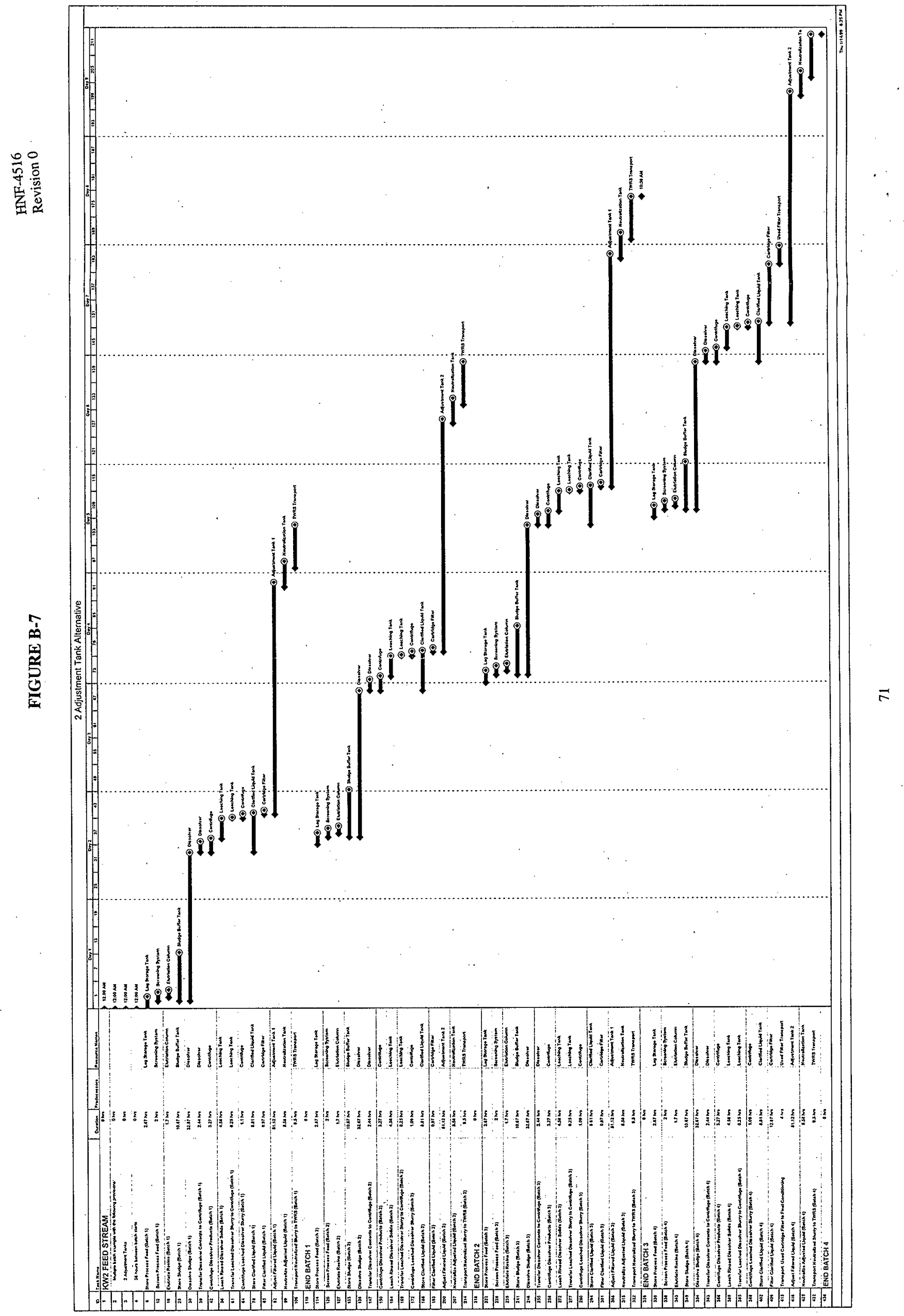


Figure B-8 -- KW2 Process Steps for 2 Adjustment Tanks Alternative

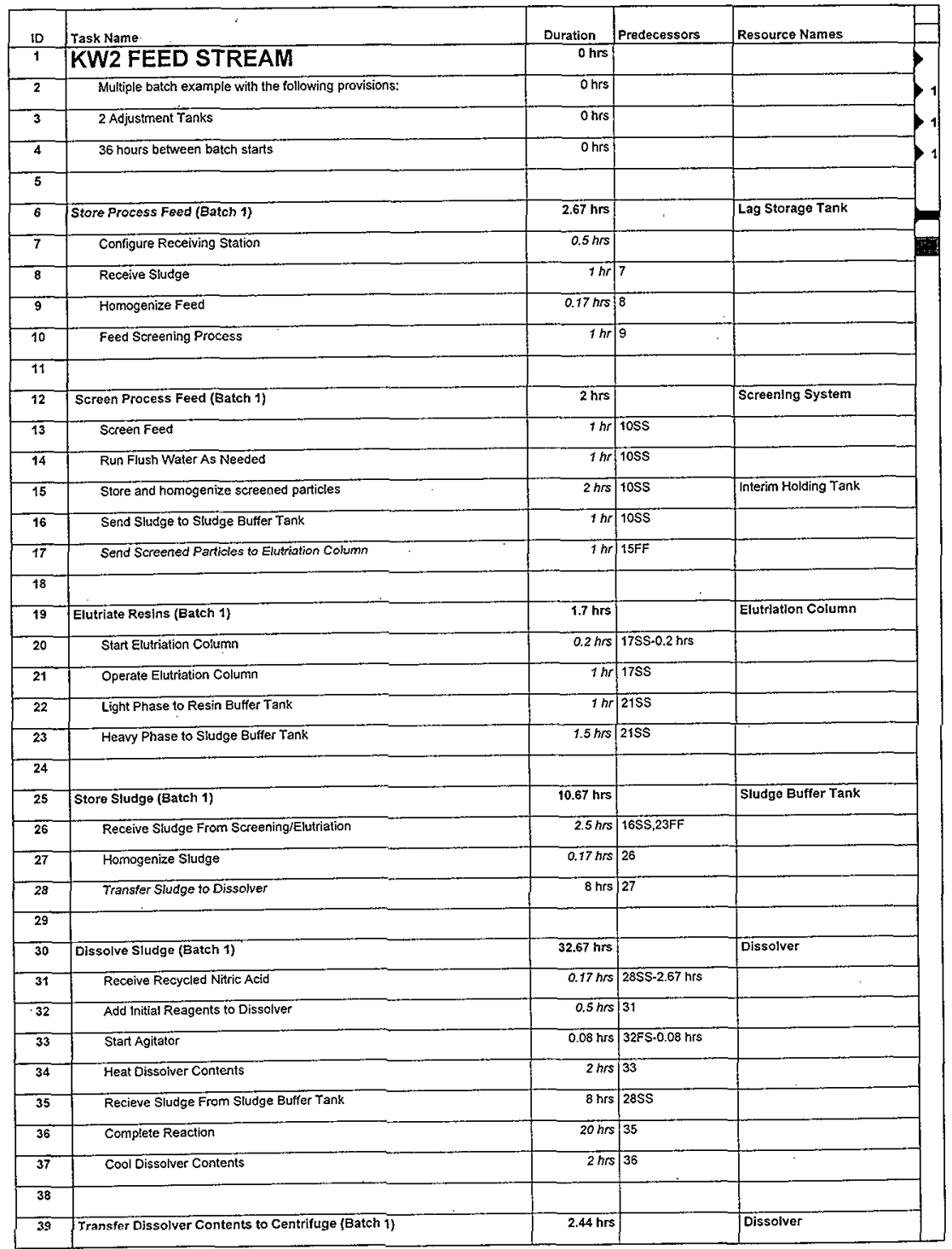


Figure B-8 - KW2 Process Steps for 2 Adjustment Tanks Alternative (cont.)

\begin{tabular}{|c|c|c|c|c|}
\hline ID & Task Name & Duration & Predecessors & Resource Narties \\
\hline 40 & Transfer $12.9 \mathrm{~kg}$ solids to Centrifuge (2441 liters) & $2.44 \mathrm{hrs}$ & 37 & \\
\hline \multicolumn{5}{|l|}{41} \\
\hline 42 & Centrifuge Dissolver Products (Batch 1) & $3.27 \mathrm{hrs}$ & & Centrlfuge \\
\hline 43 & Start Centrifuge & $0.08 \mathrm{hrs}$ & $40 \mathrm{SS}-0.08 \mathrm{hrs}$ & \\
\hline 44 & Clarify Feed From Dissolver & $2.44 \mathrm{hrs}$ & $40 S S$ & \\
\hline 45 & Transfer Liquids to Clarified Liquid Tank & $2.44 \mathrm{hrs}$ & 44SS & \\
\hline 46 & Stop Centrifuge When Clarification Complete & $0.08 \mathrm{hrs}$ & 44 & \\
\hline 47 & Flush Solids Cake With Water (60 liters) & $0.08 \mathrm{hrs}$ & 46 & \\
\hline 48 & Homogenize Solids Cake and Water & $0.08 \mathrm{hrs}$ & 47 & \\
\hline 49 & Recentrifuge Homogenized Slurny & $0.17 \mathrm{mrs}$ & 48 & \\
\hline 50 & Transfer Liquids to Clarified Liquid Tank & $0.17 \mathrm{hrs}$ & 49SS & \\
\hline 51 & Flush Solids Cake With Water (60 liters) & $0.08 \mathrm{hrs}$ & 50 & \\
\hline 52 & Homogenize Solids Cake and Water & $0.08 \mathrm{hrs}$ & 51 & \\
\hline 53 & Transfer Solution to Leaching Tank & $0.08 \mathrm{hrs}$ & 52 & \\
\hline 54 & Prepare Centrifuge for more feed & $0.08 \mathrm{hrs}$ & 53 & \\
\hline \multicolumn{5}{|l|}{55} \\
\hline 56 & Leach Rinsed Dissolver Soldds (8atch 1) & $4.58 \mathrm{hrs}$ & & Leaching Tank \\
\hline 57 & Receive Centrifuged Dissolver Slurry & $0.08 \mathrm{hrs}$ & $53 S S$ & \\
\hline 58 & Add Leaching Reagents & $0.5 \mathrm{hrs}$ & 57 & \\
\hline 59 & Homogenize Slurry to Aid Leaching & $4 \mathrm{hrs}$ & 58 & \\
\hline \multicolumn{5}{|l|}{60} \\
\hline 61 & Transfer Leached Dissolver Slurry to Centrifuge (Batch 1) & $0.25 \mathrm{hrs}$ & & Leaching Tank \\
\hline 62 & Transfer $12.2 \mathrm{~kg}$ solids to Centrifuge (245 liters) & $0.25 \mathrm{hrs}$ & 59 & \\
\hline \multicolumn{5}{|l|}{63} \\
\hline 64 & Centrifuge Leached Dissolver Siurry (Batch 1 ) & $1.1 \mathrm{hrs}$ & & Centrifuge \\
\hline 65 & Start Centrifuge & $0.08 \mathrm{hrs}$ & $62 \$ \$-0.08$ hrs & \\
\hline 66 & Clarify Feed From Leaching Tank & $0.25 \mathrm{hrs}$ & $62 S S$ & \\
\hline 87 & Transfer Liquids to Clárified Liquid Tank & $0.25 \mathrm{hrs}$ & 66ss & \\
\hline 68 & Stop Centrifuge When Clarification Complete & $0.08 \mathrm{hrs}$ & 66 & \\
\hline 69 & Flush Solids Cake With Water (60 itiers) & $0.08 \mathrm{hrs}$ & 68 & \\
\hline 70 & Homogenize Solids Cake and Water & $0.08 \mathrm{hrs}$ & 69 & \\
\hline 71 & Recentrifuge Homogenized Slurry & $0.17 \mathrm{hrs}$ & 70 & \\
\hline 72 & Transfer Liquids to Clarified Liquid Tank & $0.17 \mathrm{hrs}$ & $715 s^{\prime}$ & \\
\hline 73 & Flush Solids Cake With Water (75 liters) & $0.1 \mathrm{hrs}$ & 72 & \\
\hline 74 & Homogenize Solids Cake and Water & $0.08 \mathrm{hrs}$ & 73 & \\
\hline 75 & Transfer Solution to Solids Reception Tank & $0.08 \mathrm{hrs}$ & 74 & \\
\hline 76 & Prepare Centrifuge for more feed & $0.08 \mathrm{hrs}$ & 75 & \\
\hline \multicolumn{5}{|l|}{77} \\
\hline 78 & Store Clarified Llquid (Batch 1 ) & 8.81 hrs & & Clarifted Liquid Tank \\
\hline
\end{tabular}


Figure B-8 -- KW2 Process Steps for 2 Adjustment Tanks Alternative (cont.)

\begin{tabular}{|c|c|c|c|c|}
\hline ID & i & Duration & Predecessors & Resource Names \\
\hline 79 & Receivè Clarified Dissolver Liquids From Centrifuge & $2,44 \mathrm{hrs}$ & $45 S S$ & \\
\hline 80 & Receive Wash Liquids From Centrifuge & $0.17 \mathrm{hrs}$ & $50 \mathrm{SS}$ & \\
\hline 81 & Receive Clariffed Leached Dissolver Slurry Liquids From Centrifuge & $0.25 \mathrm{hrs}$ & 67SS & \\
\hline 82 & Receive Wash Liquids From Centrifuge & 0.17 hrs & $72 S S$ & \\
\hline 83 & Transfer Clarified Liquid to Cartridge Filter & $0.37 h / s$ & $82 \mathrm{FS}+0.17 \mathrm{hrs}$ & \\
\hline \multicolumn{5}{|l|}{84} \\
\hline 85 & Filter Clarifled Llquid (Batch 1) & 0.97 hrs & & Cartridge Filter \\
\hline 86 & Process Clarified Liquid Through Cartridge Fitter & $0.37 \mathrm{hrs}$ & $835 s$ & \\
\hline 87 & Transfer Fiftered Liquid to Adjustment Tank & 0.37 hrs & $86 S S$ & \\
\hline 88 & Rinse Cartridge Fitter & $0.5 \mathrm{hrs}$ & 87 & \\
\hline 89 & Changeout Cartridge Filter & ohrs & $88 F S+0.1$ hrs & \\
\hline 90 & Send Used Cartridge Filter to Final Conditioning & o hrs & 89 & \\
\hline 91 & , & & & \\
\hline 92 & Adjust Filtered Liquid (Batch 1) & $51.12 \mathrm{hrs}$ & & Adjustment Tank 1 \\
\hline 93 & Receive and Store Filtered Liquid & $0.87 \mathrm{hrs}$ & $875 s$ & \\
\hline 94 & Sample and Wait For Results & $48 \mathrm{hrs}$ & 93 & \\
\hline 95 & Add Adjustment Reagents ( 1279 liters) & $1 \mathrm{hr}$ & 94 & \\
\hline 96 & Homogenize Adjusted Liquid & 0.25 hrs & 95 & \\
\hline 97 & Transfer Adjusted Liquid to Neutralization Tank & $1 \mathrm{hr}$ & 96 & \\
\hline \multicolumn{5}{|l|}{98} \\
\hline 99 & Neutrallze Adjusted Liquld (Batch 1) & $5.58 \mathrm{hrs}$ & & Neutralization Tank \\
\hline 100 & Receive and Store Adjusted Llquid & $1.08 \mathrm{hrs}$ & 97SS & \\
\hline 101 & Add Neutralization Reagents & $1 \mathrm{hr}$ & 100 & \\
\hline 102 & Homogenize and Cool Neutralized Slumy & $2 \mathrm{hrs}$ & 101 & \\
\hline 103 & Sample Skrry to Confirm TWRS Acceptability & 0 hrs & 102 & \\
\hline$\overline{104}$ & Transfer Neutralized Slumy to Transport System & $1.5 \mathrm{hrs}$ & 103 & \\
\hline \multicolumn{5}{|l|}{105} \\
\hline 106 & Transport Neutrallzed Slürry to TWRS (Batch 1) & $9.5 \mathrm{hrs}$ & & TWRS Transport \\
\hline 107 & Receive and Load Neutralized Sturty & $1.5 \mathrm{hrs}$ & 104SS & \\
\hline 108 & Transport Siutry to Tank Farms & $8 \mathrm{hrs}$ & 107 & \\
\hline \multicolumn{5}{|l|}{109} \\
\hline 110 & END BATCH 1 & O hrs & & \\
\hline 111 & This marks the end of batch 1 & O hrs & 108 & \\
\hline \multicolumn{5}{|l|}{112} \\
\hline$\overline{113}$ & $\cdot$ & & & \\
\hline 114 & Store Process Feed (Batch 2) & $2.67 \mathrm{hrs}$ & & Lag Storage Tank \\
\hline 115 & Configure Receiving Station & $0.5 \mathrm{hrs}$ & $7 S S+36$ hrs & \\
\hline 116 & Receive Slutge & $1 \mathrm{hr}$ & 115 & \\
\hline 117 & Homogenize Feed & $0.17 \mathrm{hrs}$ & 116 & \\
\hline
\end{tabular}




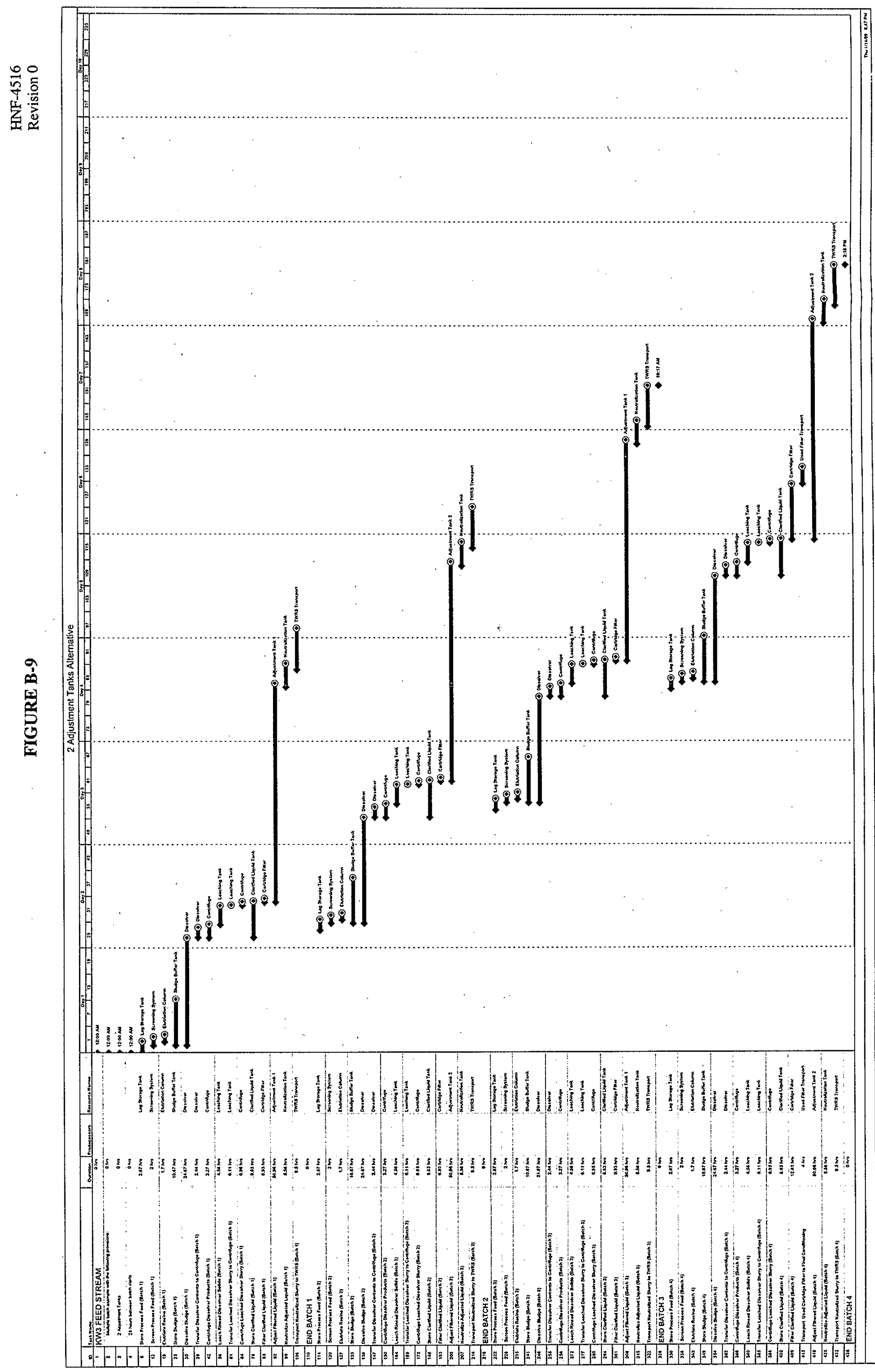


Figure B-10 -- KW3 Process Steps for 2 Adjustment Tanks Alternative

\begin{tabular}{|c|c|c|c|c|}
\hline ID & Task Name & Duration & Predecessors & Resource Names \\
\hline 1 & KN3 FEED STREAM & o hrs & & \\
\hline 3 & 2 Adjustment Tanks & o hrs & & \\
\hline 4 & 28 hours between batch starts & O hrs & & \\
\hline \multicolumn{5}{|l|}{5} \\
\hline 6 & Store Process Feed (Batch 1) & $2.67 \mathrm{hrs}$ & & Lag Storage Tank \\
\hline 7 & Configure Receiving Station & $0.5 \mathrm{hrs}$ & & \\
\hline 8 & Receive Sludge & $1 \mathrm{hr}$ & 7 & \\
\hline 9 & Homogenize Feed & 0.17 hrs & 8 & \\
\hline 10 & Feed Screening Process & $1 \mathrm{hr}$ & 9 & \\
\hline \multicolumn{5}{|l|}{11} \\
\hline 12 & Screen Process Feed (Batch 1) & 2 hrs & & Screening System \\
\hline 13 & Screen Feed & $1 \mathrm{hr}$ & $10 \$ \$$ & \\
\hline 14 & Run Flush Water As Needed & $1 \mathrm{hr}$ & 10 ss & \\
\hline 15 & Store and homogenize screened particles & $2 \mathrm{hrs}$ & 10 ss & Interim Holding Tank \\
\hline 16 & Send Sludge to Sludge Buffer Tank & $7 \mathrm{hr}$ & 10SS & \\
\hline 17 & Send Screened Particles to Elutriation Column & $1 \mathrm{hr}$ & $15 F F$ & \\
\hline \multicolumn{5}{|l|}{18} \\
\hline 19 & Elutriate Resins (Batch 1) & $1.7 \mathrm{hrs}$ & & Elutriation Column \\
\hline 21 & Operate Elutriation Column & $1 \mathrm{hr}$ & $17 S S$ & \\
\hline 22 & Light Phase to Resin Buffer Tank & $1 \mathrm{hr}$ & $215 S$ & \\
\hline 23 & Heavy Phase to Sludge Buffer Tank & $1.5 \mathrm{hrs}$ & $21 S S$ & \\
\hline 24 & . & & & . \\
\hline 25 & Store Sludge (Bateh 1) & $10.67 \mathrm{hrs}$ & & Sludge Buffer Tank \\
\hline 26 & Receive Sludge From Screening/Elutriation & $2.5 \mathrm{hrs}$ & $16 S \mathrm{~S}, 23 \mathrm{FF}$ & \\
\hline 27 & Homogenize Sludge & $0.17 \mathrm{hrs}$ & 26 & \\
\hline 28 & Transfer Sludge to Dissolver & $8 \mathrm{hrs}$ & 27 & \\
\hline \multicolumn{5}{|l|}{29} \\
\hline 30 & Dissolve Sludge (Batch 1) & $24.67 \mathrm{hrs}$ & & Dissolver \\
\hline 31 & Receive Recycled Nitric Acid & $0.17 \mathrm{hrs}$ & $28 S S .2 .67 \mathrm{hrs}$ & \\
\hline 32 & Add Initial Reagents to Dissolver & $0.5 \mathrm{hrs}$ & 31 & \\
\hline 33 & Start Agitator & $0.08 \mathrm{hrs}$ & $32 \mathrm{FS}-0.08 \mathrm{hrs}$ & \\
\hline 34 & Heat Dissolver Contents & $2 \mathrm{hrs}$ & 33 & \\
\hline 35 & Recieve Sludge From Sludge Buffer Tank & $8 \mathrm{hrs}$ & $28 S S$ & \\
\hline 36 & Complete Reaction & $12 \mathrm{hrs}$ & 35 & \\
\hline 37 & Cool Dissolver Contents & $2 \mathrm{hrs}$ & 36 & \\
\hline \multicolumn{5}{|l|}{38} \\
\hline 39 & Transfer Dissolver Contents to Centrifuge (Batch 1) & $2.44 \mathrm{hrs}$ & & Dissolver \\
\hline
\end{tabular}


Figure B-10 -- KW3 Process Steps for 2 Adjustment Tanks Alternative (cont.)

\begin{tabular}{|c|c|c|c|c|}
\hline ID & Task Name & Duration & Predecessors & Resource Names \\
\hline 40 & Transfer $5.63 \mathrm{~kg}$ solids to Centrifuge (2438 liters) & $2.44 \mathrm{hrs}$ & 37 & \\
\hline 41 & & . & & \\
\hline 42 & Centrlfuge Dissolver Products (Batch 1) & $3.27 \mathrm{hrs}$ & & Centrifuge \\
\hline 43 & Start Centrifuge & $0.08 \mathrm{hrs}$ & 40 SS-0.08 hrs & \\
\hline 44 & Clarify Feed From Dissolver & $2.44 \mathrm{hrs}$ & 40sS & \\
\hline 45 & Transfer Liquids to Clarified Liquid Tank & $2.44 \mathrm{hrs}$ & $44 S S$ & \\
\hline 46 & Stop Centrifuge When Clarification Complete & $0.08 \mathrm{hrs}$ & 44 & \\
\hline 47 & Flush Solids Cake With Water (60 liters) & $0.08 \mathrm{hrs}$ & 46 & \\
\hline 48 & Homogenize Solids Cake and Water & $0.08 \mathrm{hrs}$ & 47 & \\
\hline 49 & Recentrifuge Homogenized Slurry & $0.17 \mathrm{hrs}$ & 48 & \\
\hline 50 & Transfer Liquids to Clariîed Liquid Tank & $0.17 \mathrm{hrs}$ & $49 S S$ & \\
\hline 51 & Flush Solids Cake With Water (60 liters) & $0.08 \mathrm{hrs}$ & 50 & \\
\hline 52 & Homogenize Solids Cake and Water & $0.08 \mathrm{hrs}$ & 51 & \\
\hline 53 & Transfer Solution to Leaching Tank & $0.08 \mathrm{hrs}$ & 52 & \\
\hline 54 & Prepare Centrifuge for more feed & $0.08 \mathrm{hrs}$ & 53 & \\
\hline \multicolumn{5}{|l|}{55} \\
\hline 56 & Leach Rinsed Dissolver Sollds (Batch 1) & $4.58 \mathrm{hrs}$ & & Leaching Tank \\
\hline 57 & Receive Centrifuged Dissolver Slurry & $0.08 \mathrm{hrs}$ & 53 SS & \\
\hline 58 & Add Leaching Reagents & $0.5 \mathrm{hrs}$ & 57 & \\
\hline 59 & Homogenize Slumy to Ald Leaching & $4 \mathrm{hrs}$ & 58 & \\
\hline \multicolumn{5}{|l|}{60} \\
\hline 61 & Transfer Leached Dissolver Slurry to Centrifuge (Batch 1) & $0.11 \mathrm{hrs}$ & & Leaching Tank \\
\hline 62 & Transfer $5.3 \mathrm{~kg}$ solids to Centrifuge (107 liters) & $0.11 \mathrm{hrs}$ & 59 & \\
\hline \multicolumn{5}{|l|}{63} \\
\hline 64 & Centrifuge Leached Dissolver Slurry (Batch 1) & $0,96 \mathrm{hrs}$ & & Centrifuge \\
\hline 65 & Start Centrifuge & 0.08 hrs & $62 \mathrm{SS}-0.08 \mathrm{hrs}$ & \\
\hline 66 & Clarify Feed From Leaching Tank & $0.11 \mathrm{hrs}$ & $62 \$ \$$ & \\
\hline 67 & Transfer Liquids to Claritied Liquid Tank & $0.11 \mathrm{hrs}$ & $66 S S$ & \\
\hline 68 & Stop Centrifuge When Clarification Complete & $0.08 \mathrm{hrs}$ & 66 & \\
\hline 69 & Flush Solids Cake With Water ( 60 liters) & $0.08 \mathrm{hrs}$ & 68 & \\
\hline 70 & Homogenize Solids Cake and Water & $0.08 \mathrm{hrs}$ & 69 & \\
\hline 71 & Recentrifuge Homogenized Slurry & $0.17 \mathrm{hrs}$ & 70 & \\
\hline 72 & Transfer Liquids to Clarified Liquid Tank & $0.17 \mathrm{hrs}$ & $71 S s$ & \\
\hline 73 & Flush Solids Cake With Water (75 liters) & $0.1 \mathrm{hrs}$ & 72 & \\
\hline 74 & Homogenize Solids Cake and Water & $0.08 \mathrm{hrs}$ & 73 & \\
\hline 75 & Transfer Solution to Solids Reception Tank & $0.08 \mathrm{hrs}$ & 74 & \\
\hline 76 & Prepare Centrifuge for more feed & $0.08 \mathrm{hrs}$ & 75 & \\
\hline \multicolumn{5}{|l|}{77} \\
\hline 78 & Store Clarifled Liquld (Batch 1) & $8.63 \mathrm{hrs}$ & & Clarifted Llquld Tank \\
\hline
\end{tabular}


Figure B-10 -- KW3 Process Steps for 2 Adjustment Tanks Alternative (cont.)

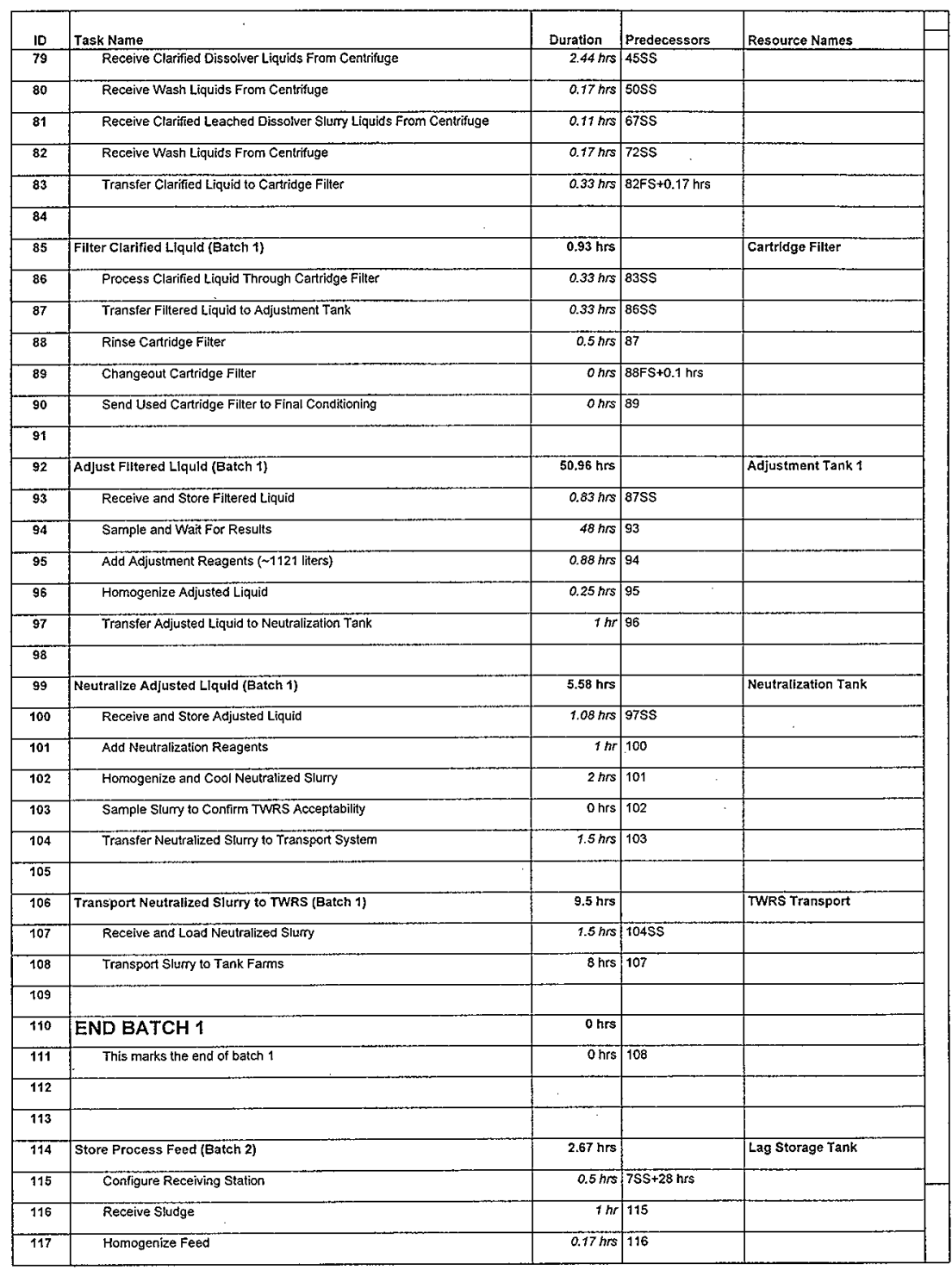


Figure B-11- Excel Spreadsheet Calculation Display

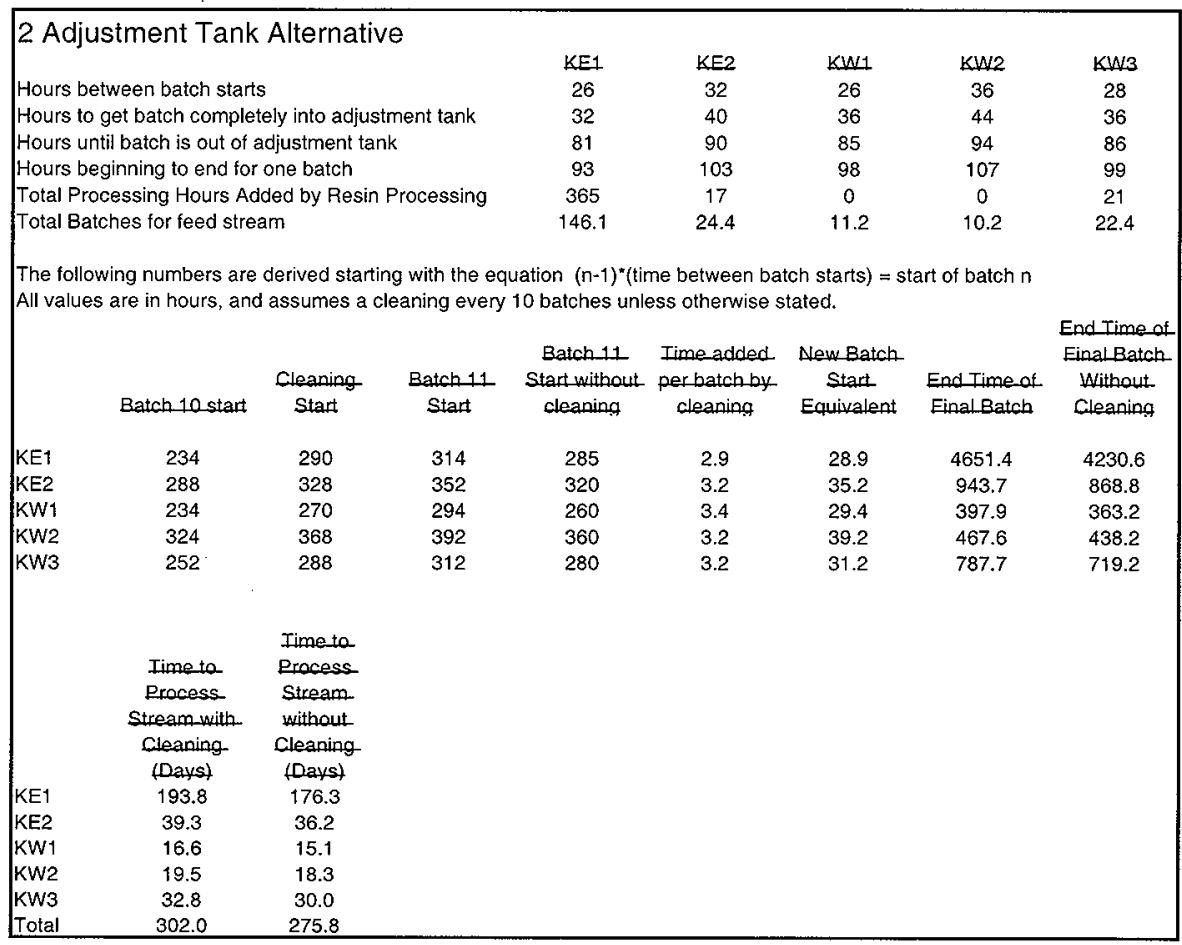


HNF-4516

Revision 0

APPENDIX C

SUPPORT INFORMATION AND CALCULATION RESULTS FOR THE 3 ADJUSTMENT TANKS ALTERNATIVE 
HNF-4516

Revision 0

This appendix contains the complete set of Microsoft Project produced summary time diagrams for the 3 Adjustment Tanks Alternative. The summary time diagrams contain the summary process steps for 4 consecutive batches. They do not include the processing of elutriation column light phases, cleaning/maintenance activities, or the grouting processes. Following each summary time diagram is a listing of all process steps for one batch of the same feed stream, their duration and related steps (predecessors), and the particular resources being used during those steps. The summary time diagrams are figures $\mathrm{C}-1, \mathrm{C}-3, \mathrm{C}-5, \mathrm{C}-7$, and $\mathrm{C}-9$. The detailed process step listings are figures $\mathrm{C}-2, \mathrm{C}-$ 4, C-6, C-8, and C-10.

The information obtained from the Microsoft Project models is then summarized in Figure C-11. Figure C-11 contains the Microsoft Excel spreadsheet used for the 3 Adjustment Tanks Alternative calculations. The top part shows the information gathered from the models, and the middle and bottom parts are the result of the calculations described in Section 5.1 and replicated in Excel. 


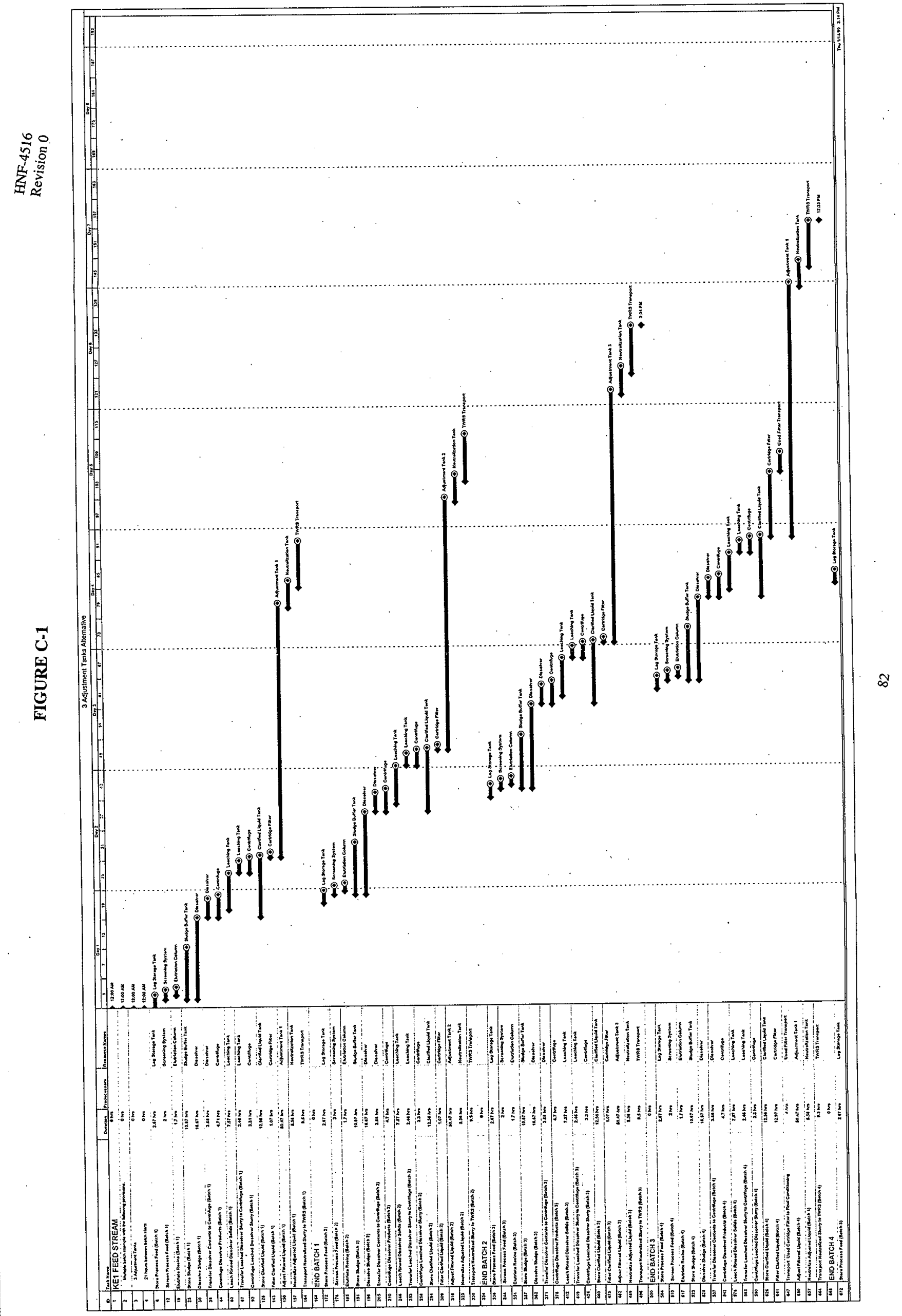


Figure C-2 - KE1 Process Steps for 3 Adjustment Tanks Alternative

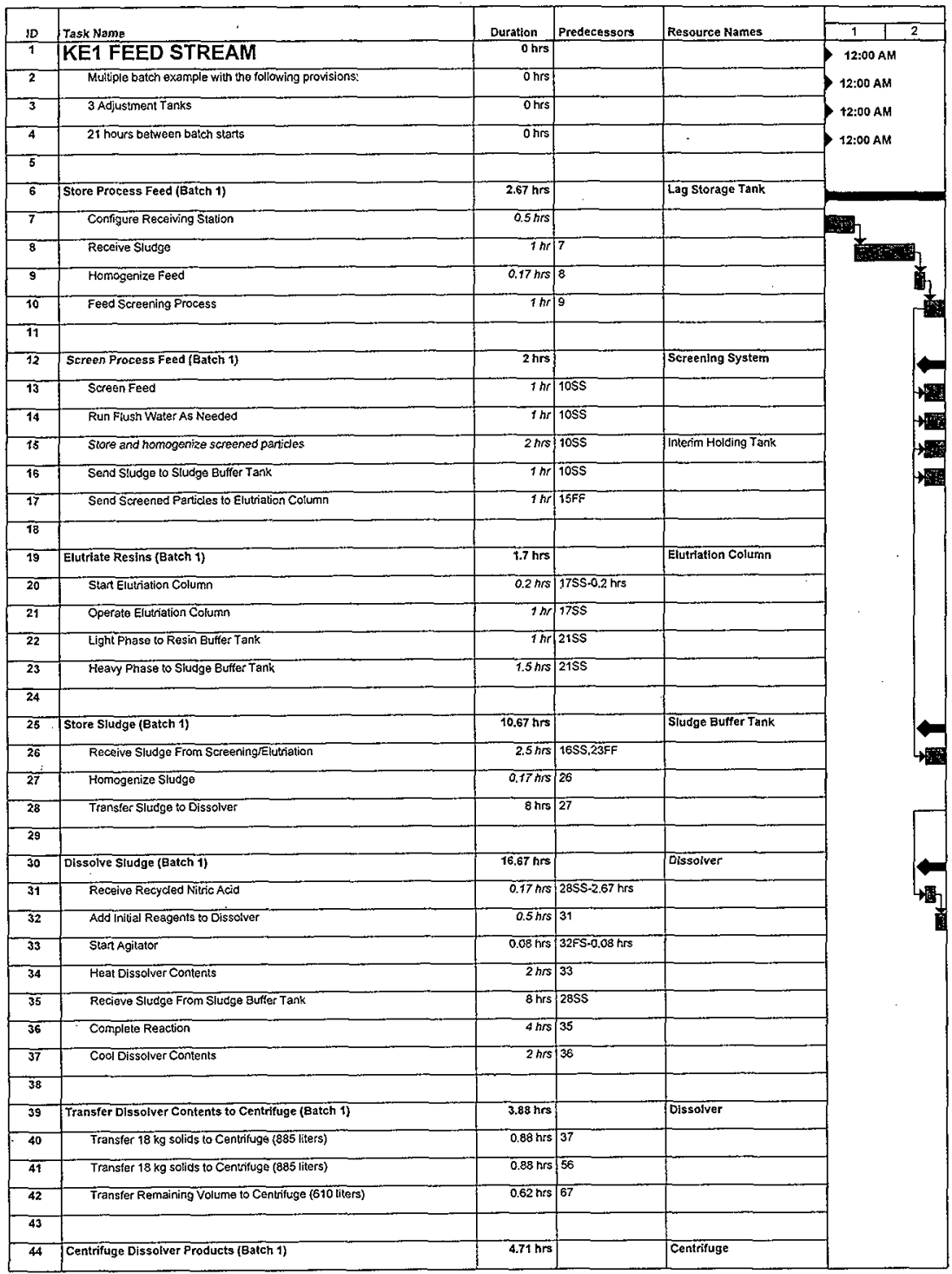


Figure C-2 -- KE1 Process Steps for 3 Adjustment Tanks Alternative (cont.)

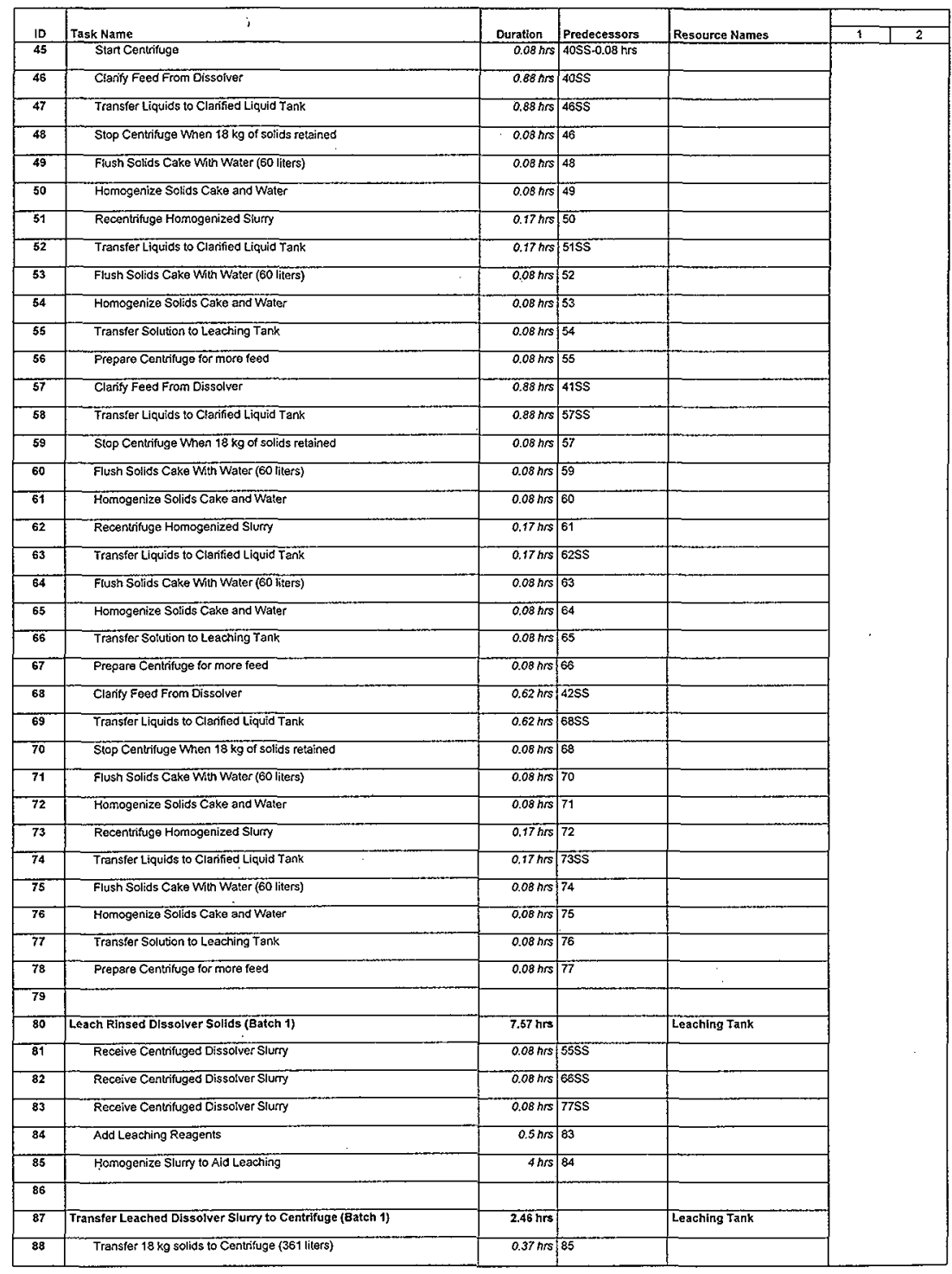


Figure C-2 -- KE1 Process Steps for 3 Adjustment Tanks Alternative (cont.)

\begin{tabular}{|c|c|c|c|c|c|c|}
\hline 10 & Task Name & Duration & Predecessors & Resource Names & 1 & 2 \\
\hline 89 & Transfer $18 \mathrm{~kg}$ solids to Centriftuge (361 liters) & $0.37 \mathrm{hrs}$ & 104 & & & \\
\hline 90 & Transfer Remaining Voltume to Centrifuge (195 filers) & $0.2 \mathrm{hrs}$ & 115 & . & & \\
\hline 91 & & & & & & \\
\hline 92 & Centrifuge Leached Dissolver Slumy (Batch 1) & 3.31 hrs & & Centrifuge & & \\
\hline 93 & Start Centrifuge & $0.08 \mathrm{hrs}$ & $8855-0.08 \mathrm{hrs}$ & & & \\
\hline 94 & Clarify feed From Leaching Tank & $0.37 \mathrm{hrs}$ & Bess & & & \\
\hline 95 & Transier Liquids to Clanfied Liquid Tank & $0.37 \mathrm{hrs}$ & 945 & & & \\
\hline 96 & Stop Centrifuge When $18 \mathrm{~kg}$ of solids retained & $0,08 \mathrm{hrs}$ & 94 & & & \\
\hline 97 & Flush Solids Cake With Waler (60 litets) & $0.08 \mathrm{hrs}$ & 86 & & & \\
\hline 98 & Homogenize Solids Cake and Water & $0.08 \mathrm{hrs}$ & 97 & & & \\
\hline 99 & Recentrifuge Homogenized Slumy & $0.17 \mathrm{hrs}$ & 88 & & & \\
\hline 100 & Transfer Liquids to Clarified Liquid Tank & $0.17 \mathrm{hrs}$ & 995 & & & \\
\hline 101 & Ffush Solids Cake With Waler (75 liters) & $0.1 \mathrm{hrs}$ & 100 & & & \\
\hline 102 & Homogenize Solids Cake and Water & $0.08 \mathrm{hrs}$ & 101 & & & \\
\hline 103 & Transfer Solution to Solids Reception Jank & $0.08 \mathrm{hrs}$ & 102 & & & \\
\hline 104 & Prepare Centifuge tor more feed & $0.08 \mathrm{hrs}$ & 103 & & & \\
\hline 105 & Clanify Feed From Leaching Tank & $0.37 \mathrm{hrs}$ & E9SS & & & \\
\hline 105 & Transfer Liquids to Clarified Liquid Tank & $0.37 \mathrm{hrs}$ & $105 \$ S$ & & & \\
\hline 107 & Slop Centrituge When $18 \mathrm{~kg}$ of solids retained & $0.08 \mathrm{hrs}$ & 105 & & & \\
\hline 108 & Flush Solids Cake With Water ( 60 liters) & 0.08 hrs & 107 & & & \\
\hline 109 & Homogenize Solids Cake and Water & $0.08 \mathrm{hrs}$ & 108 &. & & \\
\hline 110 & Recentrifuge Homogenized Slumy & $0.17 \mathrm{hrs}$ & 109 & & & \\
\hline $1+t$ & Transfer Liguids to Clantifed Liquid Tank & $0.17 h s$ & $110 \mathrm{~s}$ & & & \\
\hline 112 & Flush Solids Cake With Water (75 liters) & $0.1 \mathrm{hrs}$ & 111 & & & \\
\hline 113 & Homogenize Solids Cake and Water & $0.08 \mathrm{hs}$ & 112 & & & \\
\hline 114 & Transfer Solution to Solids Reception Tank & $0.08 \mathrm{hrs}$ & 113 & & & \\
\hline 115 & Prepare Centrifuge for more teed & $0.08 \mathrm{hrs}$ & 114 & & & \\
\hline 116 & Clasify Feed From Leaching Tank & $0.2 h r s$ & aoss & & & \\
\hline 117 & Transfer Liquids to Clarified Liquid Tank & $0.2 h n$ & 116SS & & & \\
\hline 118 & Stop Centrifuge When $18 \mathrm{~kg}$ of solids retained & $0.08 \mathrm{hrs}$ & 116 & & & \\
\hline 119 & Flush Solids Cake With Water (60 liters) & $0.08 \mathrm{hrs}$ & $\overline{118}$ & & & \\
\hline 120 & Homogenize Solids Cake and Whater & $0.08 \mathrm{hs}$ & 119 & & & \\
\hline 121 & Recentrituge Homogenized Siury & $0.17 \mathrm{hrs}$ & 120 & . & & \\
\hline 122 & Transfer Liquids to Clarified Liquid Tank & $0.17 \mathrm{hrs}$ & $121 S S$ & & & \\
\hline 123 & Flush Solids Cake With Water (75 liters) & $0.1 \mathrm{hrs}$ & 122 & & & \\
\hline 124 & Homogenize Solids Cake and Water & $0.08 \mathrm{hrs}$ & 123 & & & \\
\hline 125 & Transfer Solution to Solids Reception Tank & 0.08 hrs & 124 & & & \\
\hline 126 & Prepare Centrifuge for more feed & $0.08 \mathrm{hrs}$ & 125 & & & \\
\hline \multicolumn{5}{|l|}{127} & & \\
\hline 128 & Store Clarifled Llquid (Batch 1) & $12.56 \mathrm{hrs}$ & & Clarified Liquid Tank & & \\
\hline 129 & Receive Clarified Dissolver Liquids From Centrifuge & $0.88 \mathrm{hrs}$ & $47 S S$ & & & \\
\hline 130 & Receive Wash Liquids Ffom Centrifuge & $0.17 \mathrm{hrs}$ & 52SS & & & \\
\hline 131 & Recelve Clanfied Dissolver Liquids From Centrifuge & $0.88 \mathrm{hrs}$ & $58 S S$ & & & \\
\hline 132 & Receive Wash Liquids From Centrifuge & $0.17 \mathrm{hs}$ & 63SS & & & \\
\hline
\end{tabular}


Figure C-2 -- KE1 Process Steps for 3 Adjustment Tanks Alternative (cont.)

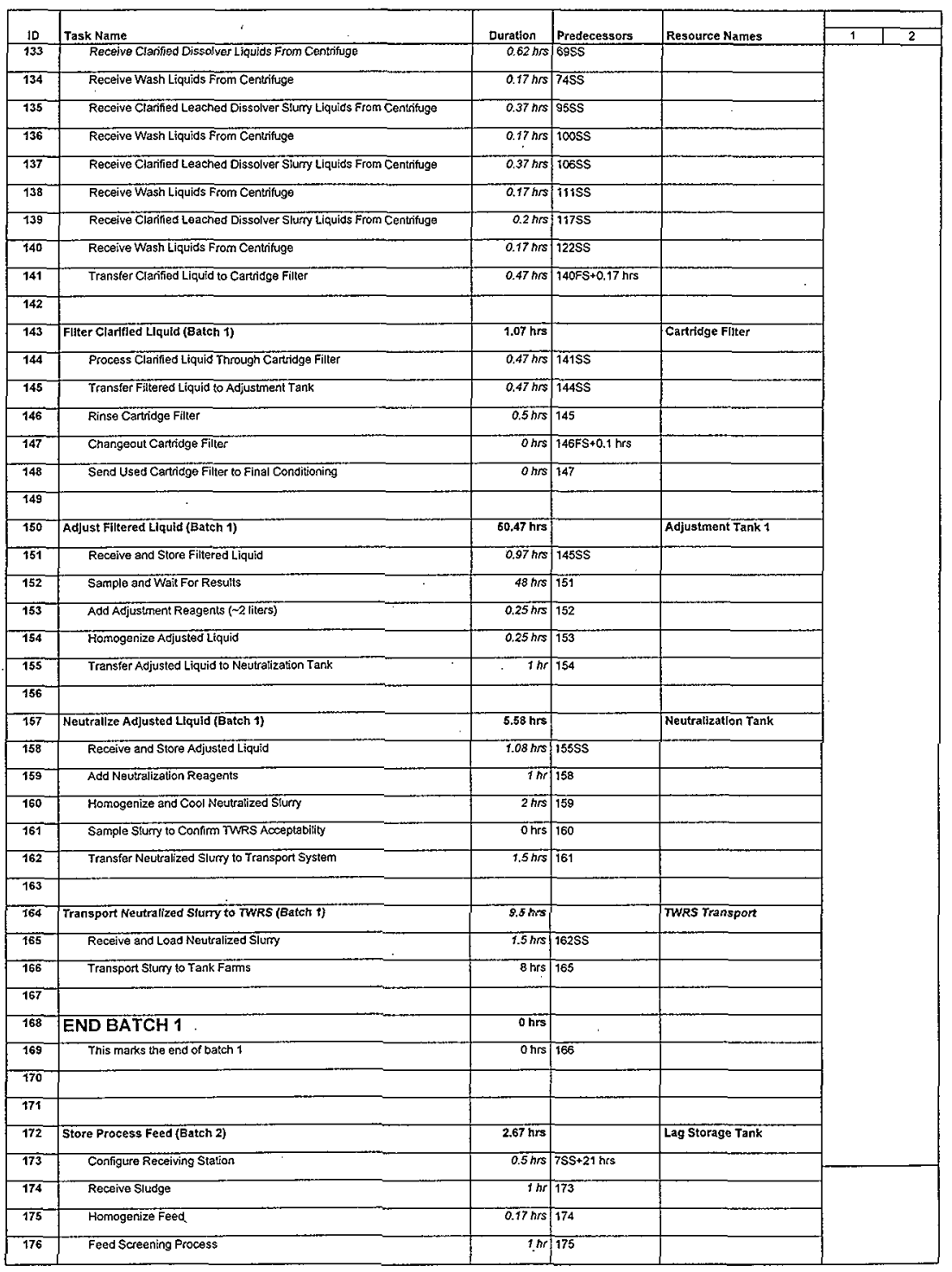




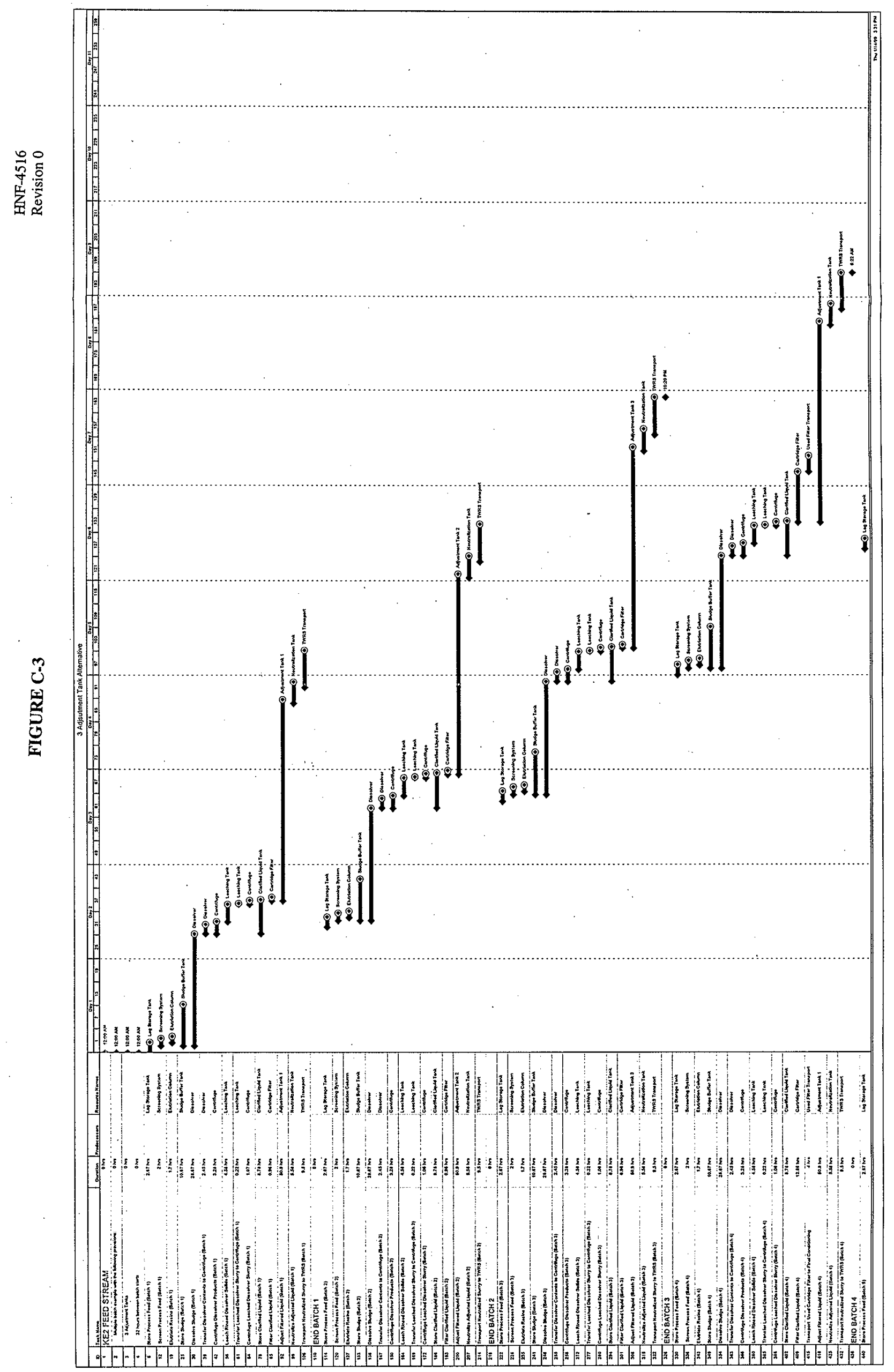


Figure C-4 - KE2 Process Steps for 3 Adjustment Tanks Alternative

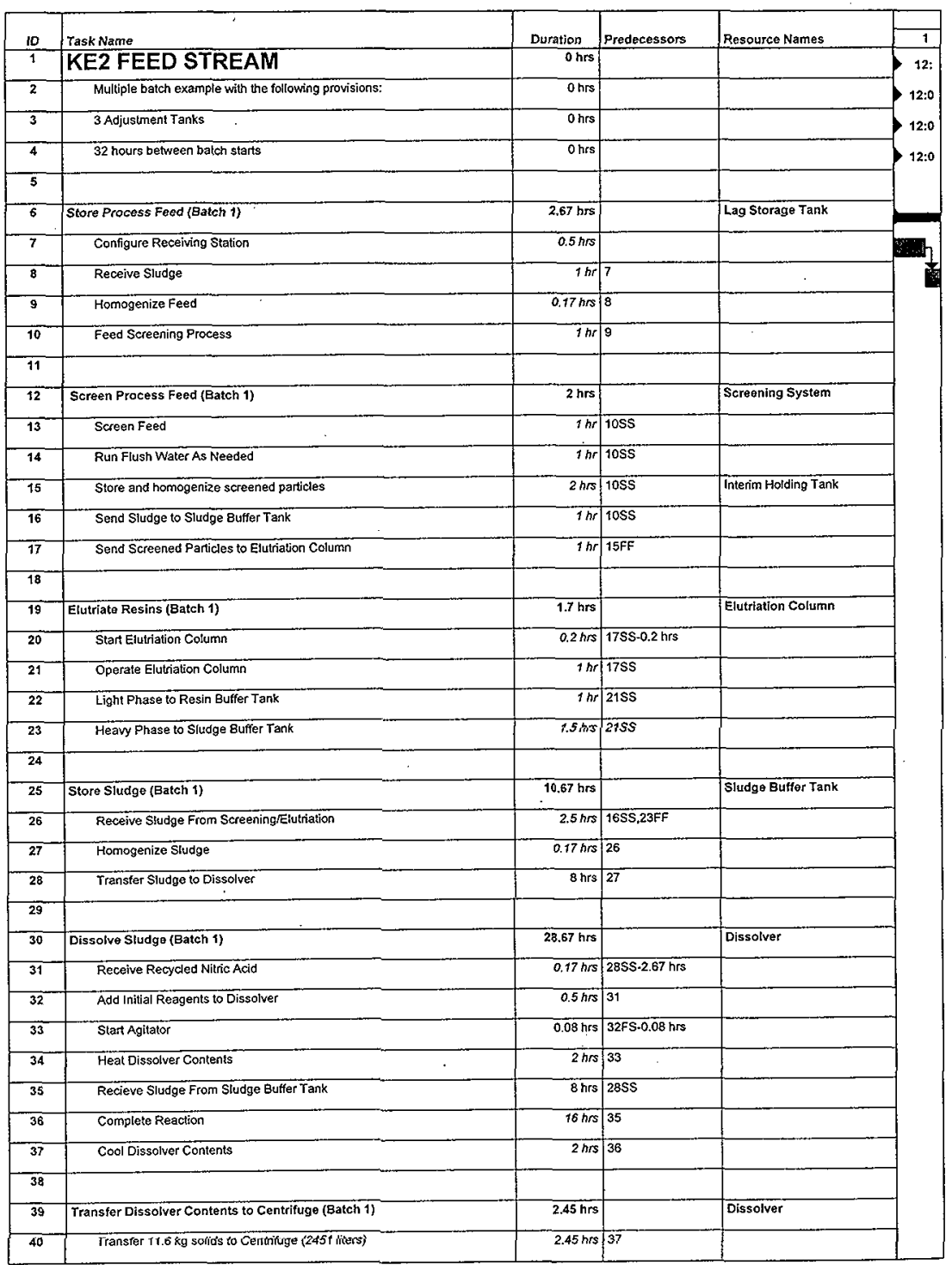


Figure C-4 -- KE2 Process Steps for 3 Adjustment Tanks Alternative (cont.)

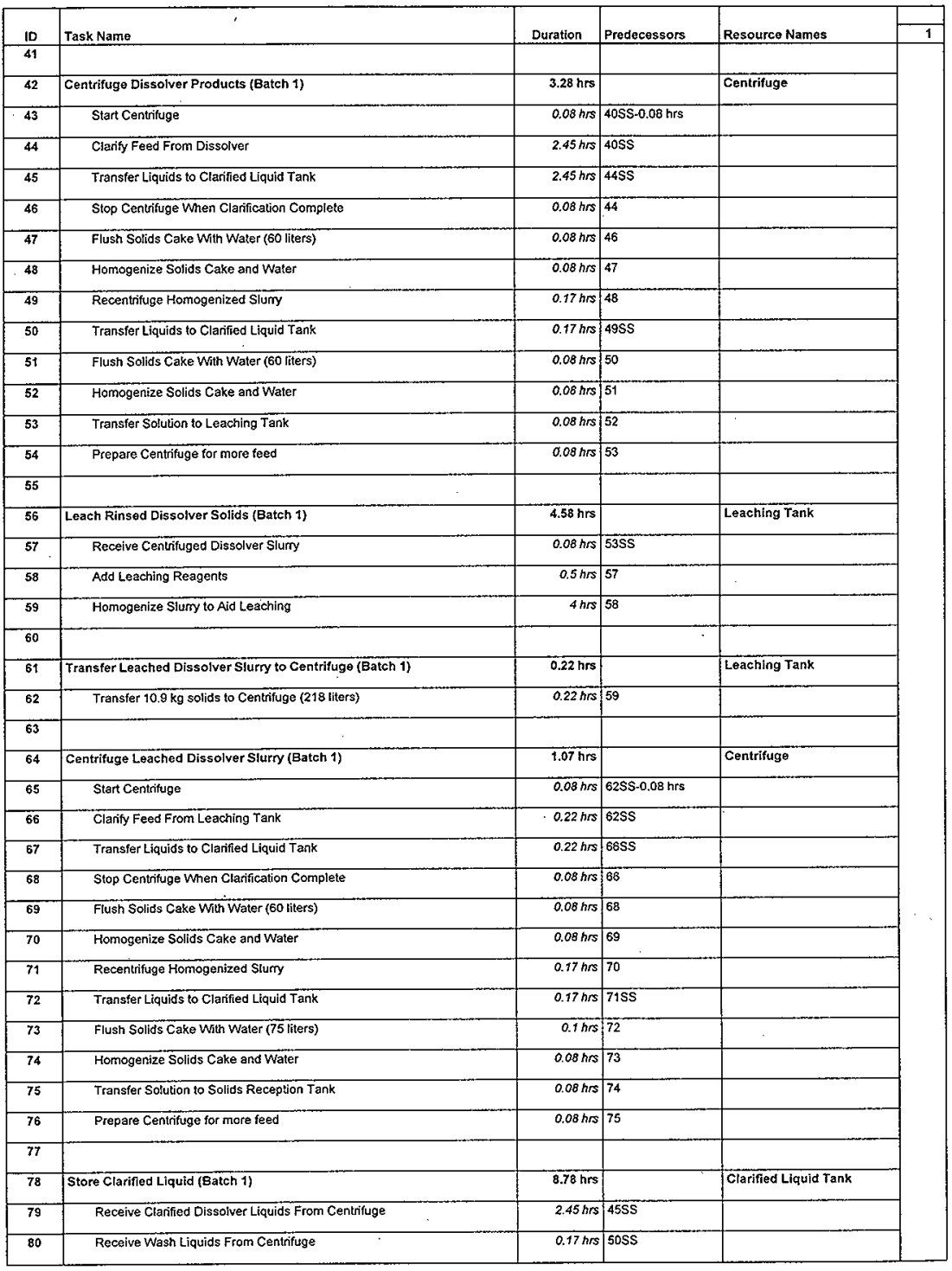


Figure C-4 -- KE2 Process Steps for 3 Adjustment Tanks Alternative (cont.)

\begin{tabular}{|c|c|c|c|c|c|}
\hline ID & Task Name & Duration & Predecessors & Resource Names & 1 \\
\hline 81 & Receive Clarified Leached Dissolver Slumy Liquids From Centrituge & $0.22 \mathrm{hrs}$ & $67 \mathrm{SS}$ & & \\
\hline 82 & Receive Wash Liquids From Centrifuge & $0.17 \mathrm{hrs}$ & $72 S S$ & & \\
\hline 83. & Transfer Clarifed Liquid to Cartridge Fister & $0.36 \mathrm{hrs}$ & $82 \mathrm{FS}+0.17 \mathrm{hrs}$ & & \\
\hline \multicolumn{5}{|l|}{84} & \\
\hline 85 & Filter Clarified Liquid (Batch 1) & $0.96 \mathrm{hrs}$ & & Cartridge Filler & \\
\hline 86 & Process Clarified Liquid Through Cartridge Filter & $0.36 \mathrm{hrs}$ & $83 S S$ & & \\
\hline 87 & Transfer Filtered Liquid to Adjustment Tank & $0.36 \mathrm{hrs}$ & $86 \$ \$$ & & \\
\hline 88 & Rinse Cartridge Filter & $0,5 h r s$ & 87 & & \\
\hline 89 & Changeout Certridge Filter & ohrs & $88 \mathrm{FS}+0.1 \mathrm{hrs}$ & & \\
\hline 90 & Send Used Cartridge Filler to Final Conditioning & ohrs & 89 & & \\
\hline \multicolumn{5}{|l|}{91} & \\
\hline 92 & Adjust Filtered Liquid (Batch 1) & 50.9 hrs & & Adjustment Tank 1 & \\
\hline 93 & Receive and Store Fittered Liquid & $0.86 \mathrm{hrs}$ & $87 S S$ & . & \\
\hline 94 & Sample and Wait For Results & $48 \mathrm{hrs}$ & 93 & & \\
\hline 95 & Add Adjustment Reagents ( 1010 liters) & $0.79 \mathrm{hrs}$ & 94 & & \\
\hline 96 & Homogenize Ádjusted Liquid & $0.25 \mathrm{hrs}$ & 95 & & \\
\hline 97 & Transter Adjusted Liquid to Neutralization Tank & $1 \mathrm{hr}$ & 96 & & \\
\hline \multicolumn{5}{|l|}{98} & \\
\hline 99 & Noutralize Adjusted Liquid (Batch 1) & 5.58 hrs & & Neutralization Tank & \\
\hline 102 & Homogenize and Cool Neutralized Slumy & $2 h r s$ & 101 & & \\
\hline 103 & Sample Siumy to Confim TWRS Acceptability & Ohrs & 102 & & \\
\hline 104 & Transfer Neutralized Slumy to Transport System & $1.5 \mathrm{hrs}$ & 103 & & \\
\hline \multicolumn{5}{|l|}{105} & \\
\hline 106 & Transport Neutralized Slurry to TWRS (Batch 1) & 9.5 hrs & & TWRS Transport & \\
\hline 107 & Receive and Load Neutralized Slurry & $1.5 \mathrm{hrs}$ & $104 S S$ & & \\
\hline 108 & Transport Slurry to Tank Farms & 8 hrs & 107 & & \\
\hline \multicolumn{5}{|l|}{109} & \\
\hline 110 & END BATCH 1 & 0 hrs & & & \\
\hline 111 & This marks the end of batch 1 & $0 \mathrm{hrs}$ & 108 & & \\
\hline \multicolumn{5}{|l|}{112} & \\
\hline \multicolumn{5}{|l|}{113} & \\
\hline 114 & Store Process Feed (Batch 2) & $2,67 \mathrm{hrs}$ & & Lag Storage Tank & \\
\hline 115 & Configure Receiving Station & $0.5 \mathrm{hrs}$ & $7 \mathrm{SS}+32 \mathrm{hrs}$ & & \\
\hline 116 & Receive Sludge & $1 \mathrm{hr}$ & 115 & & \\
\hline 117 & Homogenize Feed & $0.17 \mathrm{hrs}$ & 116 & & \\
\hline 118 & Feed Screening Process & $f h r$ & 117 & & \\
\hline \multicolumn{5}{|l|}{119} & \\
\hline 120 & Screen Process Feed (Batch 2) & 2 hrs & & Screening System & \\
\hline
\end{tabular}




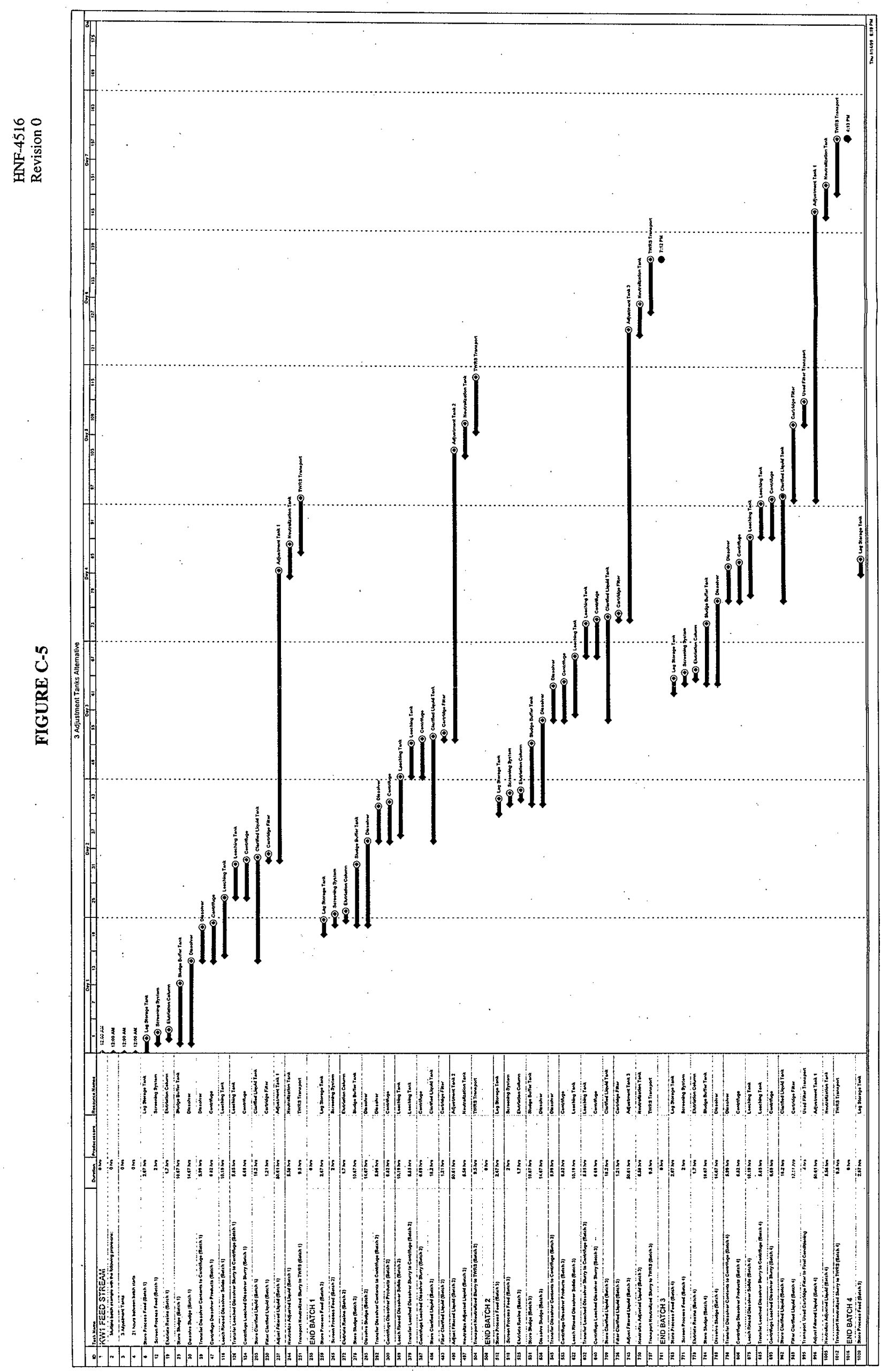


Figure C-6 - KW1 Process Steps for 3 Adjustment Tanks Alternative

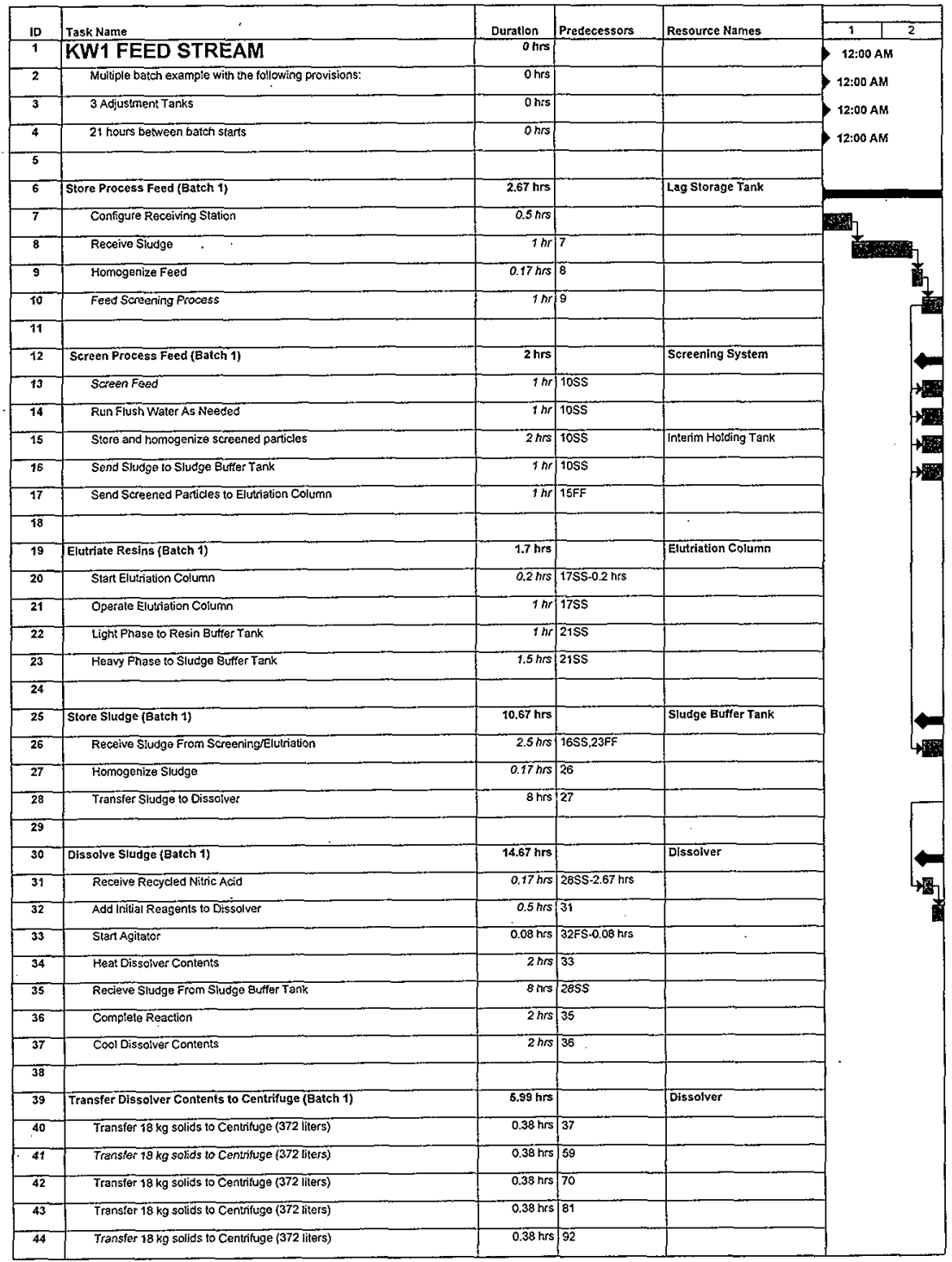


Figure C-6 - KW1 Process Steps for 3 Adjustment Tanks Alternative (cont.)

\begin{tabular}{|c|c|c|c|c|c|c|}
\hline 10 & Task Name & Duration & Predecessors & Resource Names & \multirow{2}{*}{\multicolumn{2}{|c|}{\begin{tabular}{l|l}
1 & $\cdot$ \\
\end{tabular}}} \\
\hline 45 & Transler Remaining Volume to Centrifuge (355 liters) & $0.36 \mathrm{hrs}$ & 103 & & & \\
\hline \multicolumn{7}{|l|}{46} \\
\hline 47 & Centrifuge Dlssolver Products (Batch 1) & $6.82 \mathrm{hrs}$ & & Centrifuge & & \\
\hline 48 & Start Centifuge & $0.08 \mathrm{hrs}$ & $40 \mathrm{SS} 0.08 \mathrm{hrs}$ & & & \\
\hline 49 & Clatify Feed From Dissolvef & $0.38 \mathrm{hrs}$ & $40 \mathrm{SS}$ & & & \\
\hline 50 & Transfer Liquids to Clarified Liquid Tank & $0.38 \mathrm{hrs}$ & 49SS & & & \\
\hline 51 & Stop Centiffuge When $18 \mathrm{~kg}$ of solits retained & $0.08 \mathrm{his}$ & 49 & & & \\
\hline 52 & Flush Solids Cake With Water (60 tile's) & $0.08 \mathrm{hrs}$ & 51 & & & \\
\hline 53 & Homogenize Solids Cake and Water & $0.08 \mathrm{hrs}$ & 52 & & & \\
\hline$\overline{54}$ & Recentrifuge Homogenized Slurry & 0.17 hrs & 53 & & & \\
\hline 55 & Transfer Liquids to Clarified Liquid Tark & $0.17 \mathrm{hrs}$ & $54 \$ \$$ & & & \\
\hline 56 & Flush Solids Cake With Water (60 liters) & $0,08 \mathrm{hrs}$ & 55 & & & \\
\hline 57 & Homogenize Solids Cake and Water & $0.08 \mathrm{hrs}$ & 56 & & & \\
\hline 58 & Transfer Solution to Leaching Tank & $0.08 \mathrm{hrs}$ & 57 & & & \\
\hline 59 & Prepare Centinfuge for more feed & $0.08 \mathrm{hrs}$ & 58 & & & \\
\hline 60 & Clarify Feed From Dissolver & $0.38 \mathrm{hrs}$ & 4 ISS & & & \\
\hline 61 & Transfer Liquids 10 Clarifed Liquid Tank & $0.38 \mathrm{hrs}$ & 6055 & & & \\
\hline 62 & Stop Cenlrifuge When $18 \mathrm{~kg}$ of solids retained & $0.08 \mathrm{hrs}$ & 60 & & & \\
\hline 63 & Flush Solids Cake With Water (60 liters) & $0.08 \mathrm{hrs}$ & 62 & & & \\
\hline 64 & Homogenize Solids Cake and Water & $0.08 \mathrm{hrs}$ & 63 & & & \\
\hline 65 & Recentrifuge Homogenized Siury & $0.17 \mathrm{hrs}$ & 64 & & & \\
\hline 66 & Transfer Liquids to Clarifed Liquid Tank & $0.17 \mathrm{hrs}$ & $65 S S$ & & · & \\
\hline 67 & Flush Solids Cake Wath Water (60 liters) & $0,08 \mathrm{hrs}$ & 66 & & & \\
\hline 68 & Homogenize Solids Cake and Water & $0.08 \mathrm{hrs}$ & 67 & & & \\
\hline 69 & Transfer Solution to Leaching Tank & $0.08 \mathrm{hrs}$ & 68 & & & \\
\hline 70 & Prepare Centrifuge for more feed & $0.08 \mathrm{hrs}$ & 69 & & & \\
\hline 71 & Clanty Feed From Dissolver & $0.38 \mathrm{hrs}$ & $\overline{425 S}$ & & & \\
\hline 72 & Transfer Liquids to Clarified Liquid Tank & $0.38 \mathrm{hrs}$ & 7155 & & & \\
\hline 73 & Stop Centrifuge When $18 \mathrm{~kg}$ of solids retained & $0,08 \mathrm{hrs}$ & 71 & & & \\
\hline 74 & Flush Solids Cake With Water (60 liters) & $0.08 h r s$ & 73 & & & \\
\hline 75 & Homagenize Solids Cake and Water & $0.08 \mathrm{hs}$ & 74 & & & \\
\hline 76 & Recentrifuge Homogenized Slurry & $0.17 \mathrm{hrs}$ & 75 & & & \\
\hline 77 & Transfer Liquids to Clanified Liquid Tank & $0.17 \mathrm{hrs}$ & 7658 & & & \\
\hline 78 & Flush Solids Cake With Water (60 gters) & $0.08 \mathrm{hrs}$ & 77 & & & \\
\hline 79 & Homogenize Solids Cake and Water & $0.00 \mathrm{hrs}$ & 78 & & & \\
\hline 80 & Transfer Solution to Leaching Tank & 0.06 hrs & 79 & & & \\
\hline 81 & Frepare Centrifuge for more feed & $0.08 \mathrm{hrs}$ & 80 & & & \\
\hline 82 & Clatify Feed From Dissolver & $0.38 \mathrm{hrs}$ & $43 S S$ & & & \\
\hline 83 & Transier Liquids to Clanifed Liquid Tank & 0.38 hrs & $82 s$ & & & \\
\hline 84 & Stop Centrifuge When $18 \mathrm{~kg}$ of solid's retained & 0.08 hrs & 82 & & & \\
\hline 85 & Flush Solids Cake Whth Water (60 liters) & $0.08 \mathrm{hrs}$ & 84 & & & \\
\hline 86 & Homogenize Solids Cake and Water & $0.08 \mathrm{hrs}$ & 85 & & & \\
\hline 87 & Recentrifuge Homogenized Siury & $0.17 \mathrm{hrs}$ & 86 & & & \\
\hline 88 & Transfer Liquids to Clarified Liquid Tank & $0.17 \mathrm{hrs}$ & $875 S$ & & & \\
\hline
\end{tabular}


Figure C-6 -- KW1 Process Steps for 3 Adjustment Tanks Alternative (cont.)

\begin{tabular}{|c|c|c|c|c|c|c|}
\hline 10 & TTak Nano & \multirow{2}{*}{ Duration } & \multirow{2}{*}{ Predecessors } & \multirow{2}{*}{ Resource Names } & \multirow{2}{*}{\begin{tabular}{l|l}
1 & 1 \\
\end{tabular}} & \multirow{2}{*}{2} \\
\hline 89 & Task Name & & & & & \\
\hline 90 & Homogenize Solids Cake and Water & $0.08 \mathrm{hrs}$ & 89 & & & \\
\hline 99 & Transfer Solution to Leaching Tank & $0.08 \mathrm{hs}$ & 90 & & & \\
\hline 92 & Prepare Centrifuge for more feed & $0.08 \mathrm{hrs}$ & 91 & & & \\
\hline 93 & Clarify Feed From Dissolver & $0.38 \mathrm{Ars}$ & $44 S S$ & & & \\
\hline 94 & Transler Liquids to Clanified Liquid Tank & 0.38 hrs & 9355 & & & \\
\hline 85 & Stop Centrifuge When $18 \mathrm{~kg}$ of sctids retained & $0.08 \mathrm{hrs}$ & 93 & & & \\
\hline 96 & Flush Solids Cake With Water (60 liters) & 0.08 hrs & 95 & & & \\
\hline 97 & Homogenize Sotids Cake and water & $0.08 \mathrm{hrs}$ & 96 & & & \\
\hline 98 & Recentifiuge Homogenized Slurry & $0.17 \mathrm{hrs}$ & 97 & & & \\
\hline 99 & Iransfer Liquids to Clarified Liquid Tank & $0.17 \mathrm{hrs}$ & $985 s$ & & & \\
\hline 100 & Flush Solids Cake With Water (60 liters) & $0.08 \mathrm{hrs}$ & 99 & & & \\
\hline 101 & Homogenize Solids Cake and water & $0.08 \mathrm{hrs}$ & 100 & & & \\
\hline$\overline{102}$ & Transier Solution to Leaching Tank & $0.08 \mathrm{hrs}$ & 101 & & & \\
\hline 103 & Prepare Centrifuge for more feed & $0.08 \mathrm{hrs}$ & 102 & & & \\
\hline 104 & Clarity feed From Dissolver & $0.36 \mathrm{hrs}$ & $4 \overline{5 S S}$ & & & \\
\hline 105 & Transfer Liquids to Clarfied Liquid Tank & $0.36 \mathrm{hrs}$ & 104 S & & & \\
\hline 106 & Stop Centifuge Wmen $18 \mathrm{~kg}$ of solids reteined & $0.08 \mathrm{hrs}$ & 104 & & & \\
\hline 107 & Ffush Sofids Cake With Water (60 liters) & $0.08 \mathrm{hrs}$ & $10 \%$ & & & \\
\hline 108 & Homogenize Solids Cake and Water & 0.08 nos & 107 & & & \\
\hline 109 & Recentrifuge Homogenized Slury & $0.17 \mathrm{hrs}$ & 108 & & & \\
\hline 110 & Transter Liquids to Clarified Liquid Tank & $0.17 \mathrm{hrs}$ & 109ss & & & \\
\hline 111 & Flush Solids Cake With Water (60 liters) & $0.08 \mathrm{hrs}$ & 110 & & & \\
\hline 112 & Homogenize Solids Cake and Water & $0.08 \mathrm{hrs}$ & 111 & & & \\
\hline$\overline{113}$ & Transfer Solution to Leaching Tank & $0,08 \mathrm{hrs}$ & 112 & & & \\
\hline$\overline{114}$ & Prepare Centrifuge for more feed & $0.08 \mathrm{hrs}$ & $11 \overline{3}$ & & & \\
\hline 115 & & & & & & \\
\hline 116 & Leach Rinsed Dlssolver Solids (Batch 1) & $10.19 \mathrm{hrs}$ & & Leaching Tank & & \\
\hline 117 & Receive Centrifuged Dissolver Stury & $0.08 \mathrm{hrs}$ & sess & & & \\
\hline 118 & Receive Centriftged Dissolver Siumy & $0.08 \mathrm{hrs}$ & $695 s$ & & & \\
\hline 119 & Receive Centrifuged Dissolver Slumy & $0.08 \pi \mathrm{s}$ & 20SS & & & \\
\hline$\overline{120}$ & Receive Centrifuged Dissolve: Slumy & 0.08 hrs & 915s & & & \\
\hline 121 & Receive Centrituged Dissolver Slurry & $0.08 \mathrm{hrs}$ & $1025 \mathrm{~s}$ & & & \\
\hline 122 & Receive Centrifuged Dissolver Slury & $0.08 \mathrm{hrs}$ & $1135 S$ & & & \\
\hline 123 & Add Leaching Reagenls & $0.5 \mathrm{hrs}$ & $1 \overline{122}$ & & & \\
\hline 124 & Homogenize slutry to Aid Leaching & d hrs & 123 & & & \\
\hline 125 & & & & & & \\
\hline$\overline{126}$ & Transfer Leached Dissolver Slumy to Centrfuge (Batch 1) & $5.85 \mathrm{hrs}$ & & Leaching Tank & & \\
\hline 127 & Transfer $18 \mathrm{~kg}$ solids lo Centifuge $\{360$ liters $\}$ & $0.36 \mathrm{hrs}$ & 124 & & & \\
\hline 128 & Transfer $18 \mathrm{~kg}$ solids to Centifuge (360 siters) & $0.36 \mathrm{hrs}$ & $\overline{146}$ & & & \\
\hline 129 & Transfer $18 \mathrm{~kg}$ solids to Centriluge (360 fiters) & 0.36 hrs & 157 & & & \\
\hline 130 & Transter $18 \mathrm{~kg}$ solids to Centriluge (360 liters) & 0.36 hrs & 168 & & & \\
\hline $\overrightarrow{131}$ & Transfer $18 \mathrm{~kg}$ solids to Centrifuge (360 liters) & 0.36 his & 179 & & & \\
\hline 132 & Transfer Remaining Volume to Centifuge (228 liters) & $0.23 \mathrm{n} / \mathrm{s}$ & $\overline{190}$ & & & \\
\hline
\end{tabular}


Figure C-6 - KW1 Process Steps for 3 Adjustment Tanks Alternative (cont.)

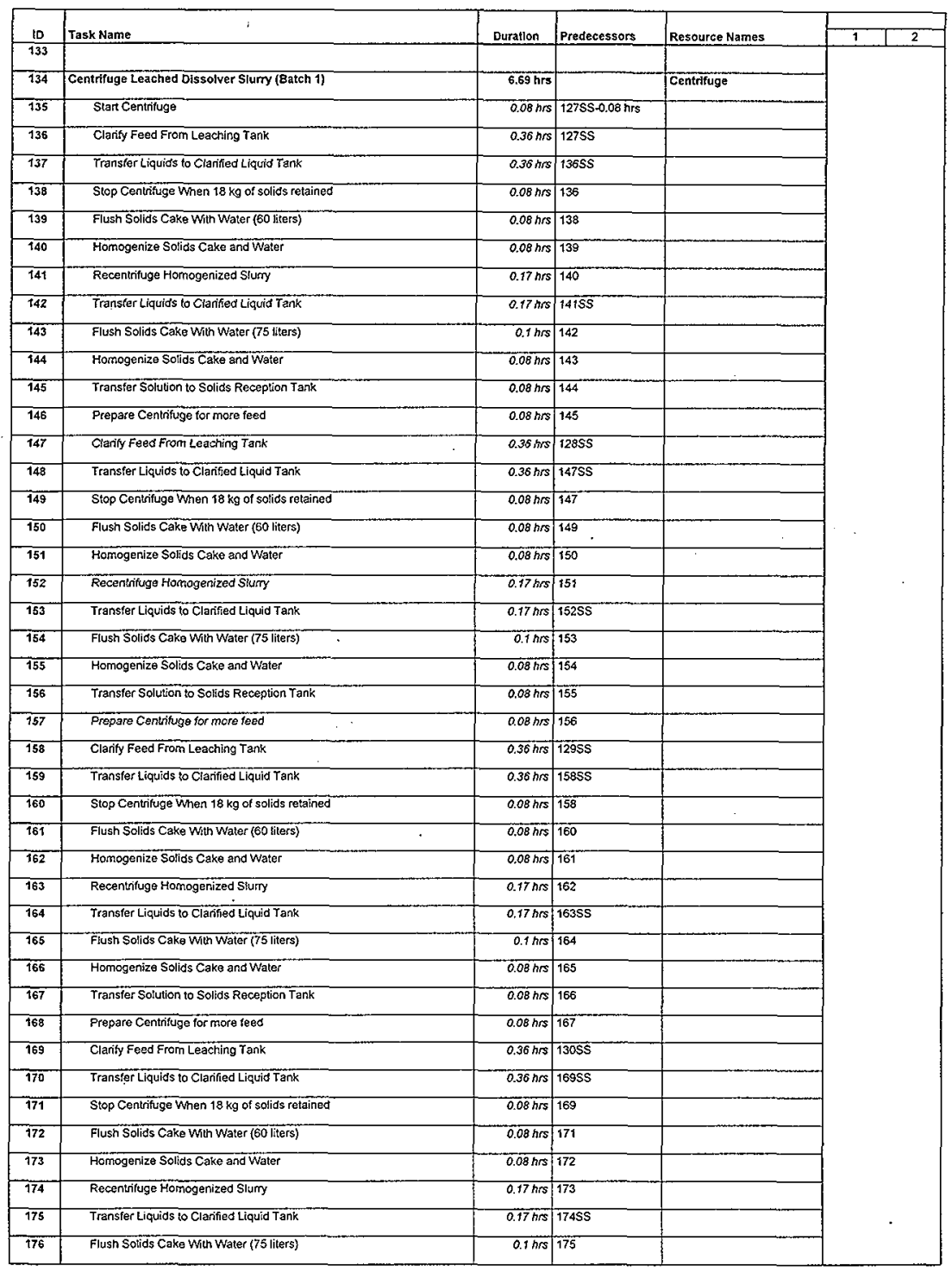


Figure C-6 -- KW1 Process Steps for 3 Adjustment Tanks Alternative (cont.)

\begin{tabular}{|c|c|c|c|c|c|c|}
\hline 10 & $I_{T}$ & & & & & \\
\hline 177 & Homogenize Solids Cake and Water & $\frac{\text { Duration }}{0.08 \mathrm{hrs}}$ & \begin{tabular}{|l} 
Preadecessors \\
176
\end{tabular} & Ressource Names & \multirow{44}{*}{. } & 2 \\
\hline 178 & Transfer Solution to Solids Reception Tank & $0.08 \mathrm{hrs}$ & 177 & & & \\
\hline 179 & Prepare Centrifuge for more feed & $0.08 \mathrm{hrs}$ & 178 & & & \\
\hline 180 & Clarify Feed From Leaching Tank & 0.36 hrs & $131 \mathrm{SS}$ & & & \\
\hline 181 & Teanster Liquids to Clarified Liquid Tank & $0.36 \mathrm{hrs}$ & $180 \mathrm{SS}$ & & & \\
\hline 182 & Stop Centrituge When $18 \mathrm{~kg}$ of solids retained & $0.08 \mathrm{hrs}$ & 180 & & & \\
\hline $18 \overline{3}$ & Flush Solids Cake With Waler (60 liters) & $0.08 \mathrm{hrs}$ & 182 & & & \\
\hline 184 & Homogenize Solids Cake and Water & $0.08 \mathrm{hrs}$ & 183 & & & \\
\hline 185 & Recentsifuge Homogenized Slutry & $0.17 \mathrm{hrs}$ & 184 & & & \\
\hline 186 & Transfer Liquids to Clarifed Liquid Tank & $0.17 n s$ & $185 \$ \$$ & & & \\
\hline 987 & Flush Solids Cake With Water (75 liters) & $0.1 \mathrm{hrs}$ & 186 & & & \\
\hline 188 & Homogenize Solids Cake and Water & $0.08 \mathrm{hrs}$ & 187 & & & \\
\hline 989 & Transfer Solution to Sofids Reception Jank & $0.06 \mathrm{hrs}$ & 188 & & & \\
\hline 190 & Prepare Centrifuge for more feed & $0.08 \mathrm{hrs}$ & 189 & & & \\
\hline 199 & Clatity Feed From Leaching Tank & $0.23 \mathrm{hs}$ & $132 s s$ & & & \\
\hline 192 & Transfer Liquids to Clarified Liquid Tank & $0.23 \mathrm{hrs}$ & 1915S & & & \\
\hline 193 & Stop Centriftige when $18 \mathrm{~kg}$ of solids retained & $0.08 \mathrm{hrs}$ & 191 & & & \\
\hline 194 & Flush Solids Cake With Water (60 liters) & $0.08 \mathrm{hrs}$ & 193 & & & \\
\hline 195 & Hornogenize Solids Cake ano Water & $0.08 \mathrm{hrs}$ & 194 & & & \\
\hline 195 & Recentrifuge Homogenized Slumy & $0.17 \mathrm{hrs}$ & 195 & & & \\
\hline 197 & Transter Liquids to Clarified Liquid Tank & $0.17 \mathrm{hrs}$ & 19655 & & & \\
\hline 198 & Flusn Solids Cake With water (75 liters) & $0.1 \mathrm{~ns}$ & 197 & & & \\
\hline 199 & Homogenize Solids Cake and Water & $0.08 \mathrm{hrs}$ & 198 & & & \\
\hline 200 & Transfer Solution to Solids Reception Tank & 0.08 hrs & 199 & & & \\
\hline 201 & Frepare Centrifuge for more feed & $0.08 \mathrm{hs}$ & 200 & & & \\
\hline \multicolumn{5}{|l|}{202} & & \\
\hline 203 & Store Clarifted Liquid (Batch 1) & $18.2 \mathrm{hrs}$ & & Clarifled Llquidd Tank & & \\
\hline 204 & Receive Clanfied Dissower Liquids From Centñfuge & $0.38 \mathrm{hrs}$ & $50 \mathrm{sS}$ & & & \\
\hline 205 & Receive Wash Liquids From Centifuge & $0.17 \mathrm{hrs}$ & 55SS & & & \\
\hline 206 & Receive Clanified Dissolver Liquids From Centrifuge & $0.38 \mathrm{hrs}$ & 615s & & & \\
\hline 207 & Receive Wash Liquids From Centrituge & $0.17 \mathrm{hrs}$ & 6655 & & & \\
\hline 208 & Receive Clanified Dissolver Liquids From Centrituge & $0.38 \mathrm{hrs}$ & $72 S S$ & & & \\
\hline 209 & Receive Wash Liquids From Centrifuge & $0.17 \mathrm{hrs}$ & $77 \overline{S S}$ & & & \\
\hline 210 & Receive Clanifed Dissoiver Liquids Ftom Centrifuge & $0.36 \mathrm{hrs}$ & 835s & & & \\
\hline 211 & Receive Wash Liquids From Centrifuge & $0.17 \mathrm{hrs}$ & 88SS & & & \\
\hline 212 & Receive Clarifiod Dissolver Liquids From Cenlsifuge & $0.38 \mathrm{hrs}$ & $94 S S$ & & & \\
\hline $\mathbf{2 i 3}$ & Receive Wash Liquids From Centrifuge & 0.17 his & 99SS & & & \\
\hline 214 & Receive Clarified Oissolver Liquids From Centrítuge & $0.36 \mathrm{hrs}$ & 10555 & & & \\
\hline$\overline{215}$ & Receive Wash Liquids From Centñtuge & $0.17 \mathrm{hrs}$ & $1105 \mathrm{~S}$ & & & \\
\hline $216^{\circ}$ & Recelve Clarified Leached Dissolver Slury Liquids From Centrifuge & $0.36 \mathrm{hrs}$ & $137 \mathrm{SS}$ & & & \\
\hline 217 & Receive Wash Liquids From Cenliftuge & $0.17 \mathrm{hrs}$ & $142 \mathrm{SS}$ & & & \\
\hline$\overline{218}$ & Receive Clanifed Leached Dissolver Slıtry Liquids From Centrifuge & $0.36 \mathrm{hrs}$ & 148SS & & & \\
\hline 219 & Receive Wash Liquids From Centríuge & $0.17 \mathrm{hrs}$ & 15355 & & & \\
\hline 220 & Receive Clanified Leached Dissolver Sturny Liquids From Cen'ifuge & $0.36 \mathrm{hrs}$ & $1595 \mathrm{~S}$ & & & \\
\hline
\end{tabular}


Figure C-6 - KW1 Process Steps for 3 Adjustment Tanks Alternative (cont.)

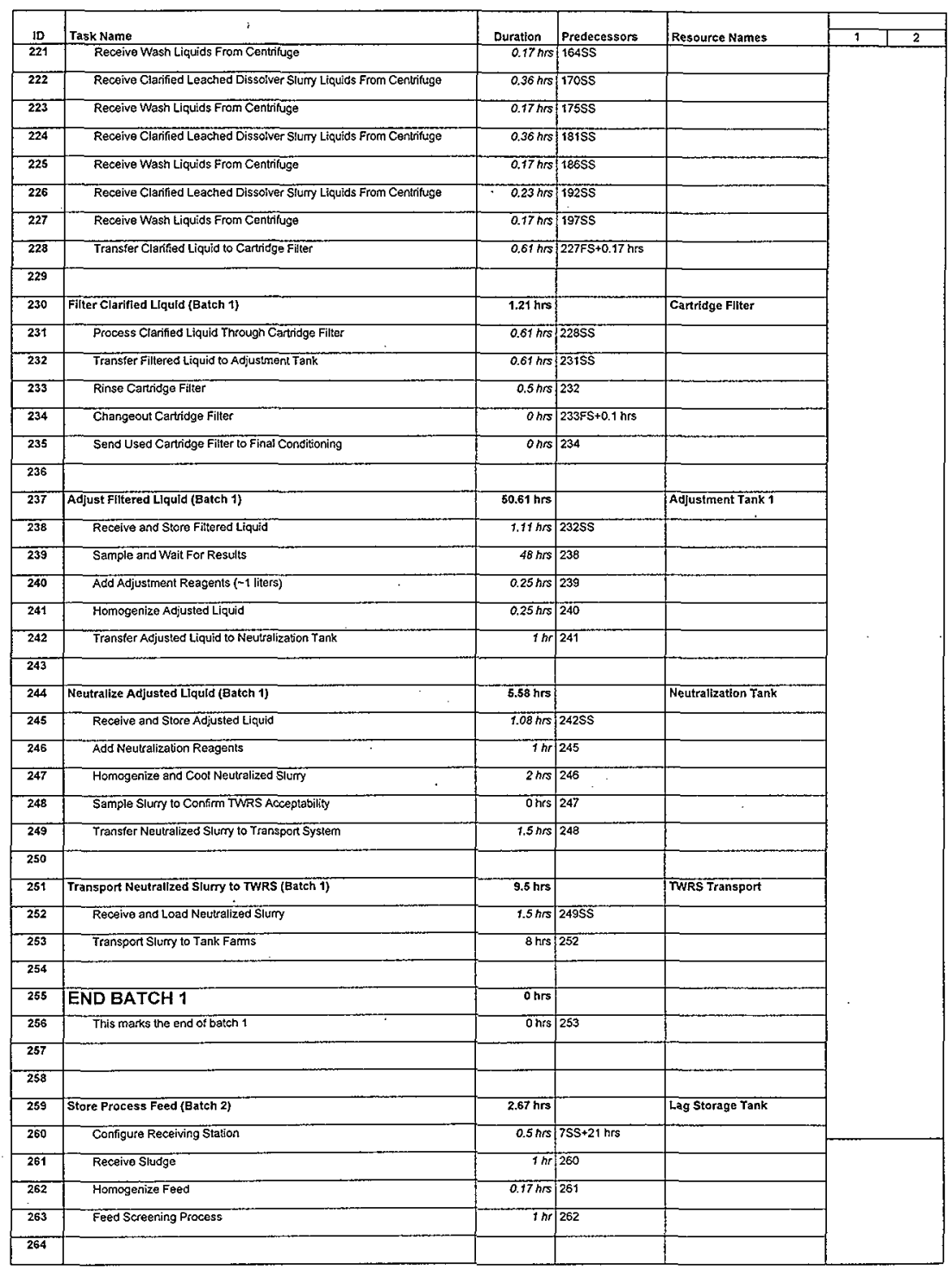




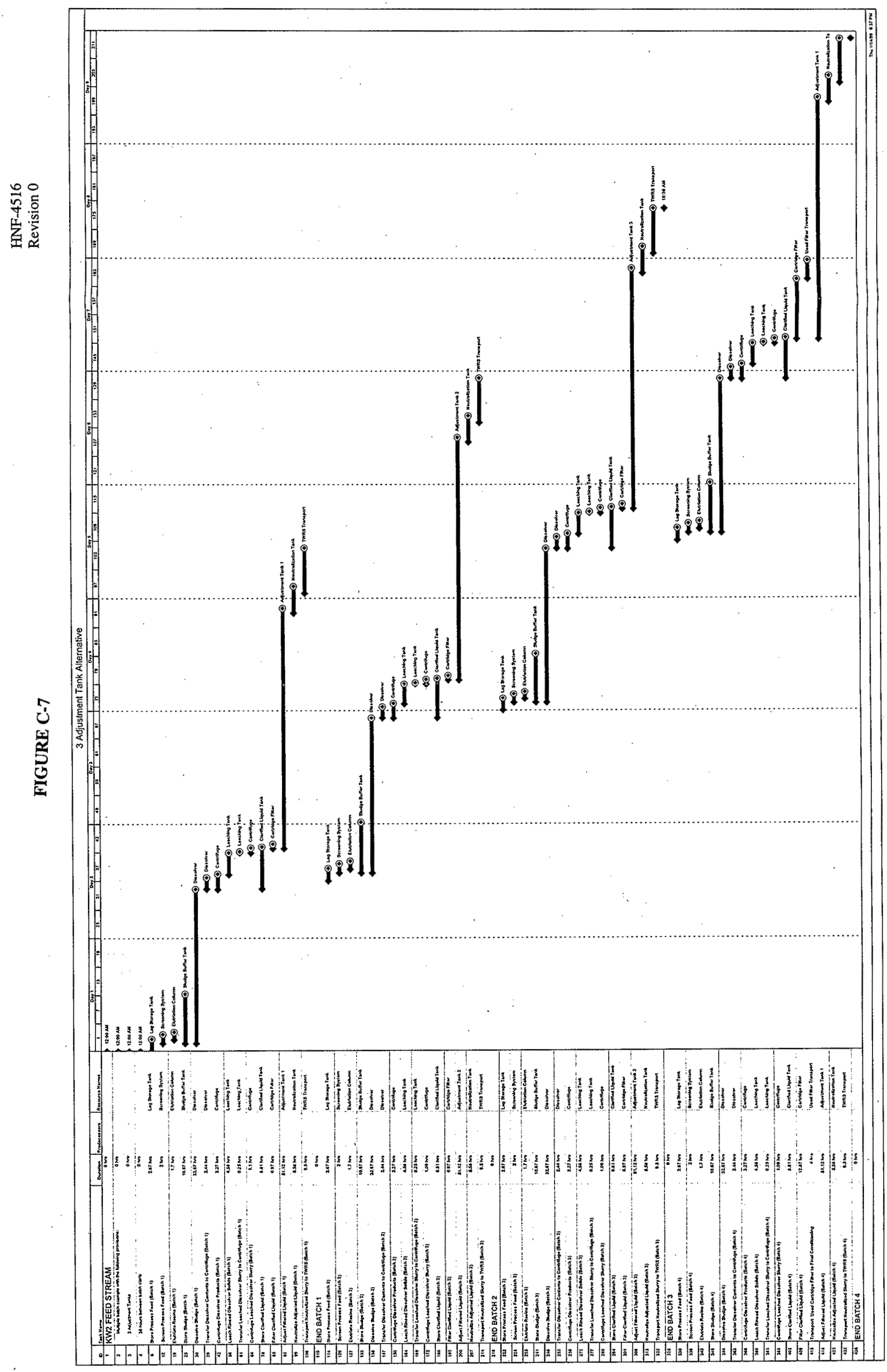


Figure C-8 -- KW2 Process Steps for 3 Adjustment Tank Alternative

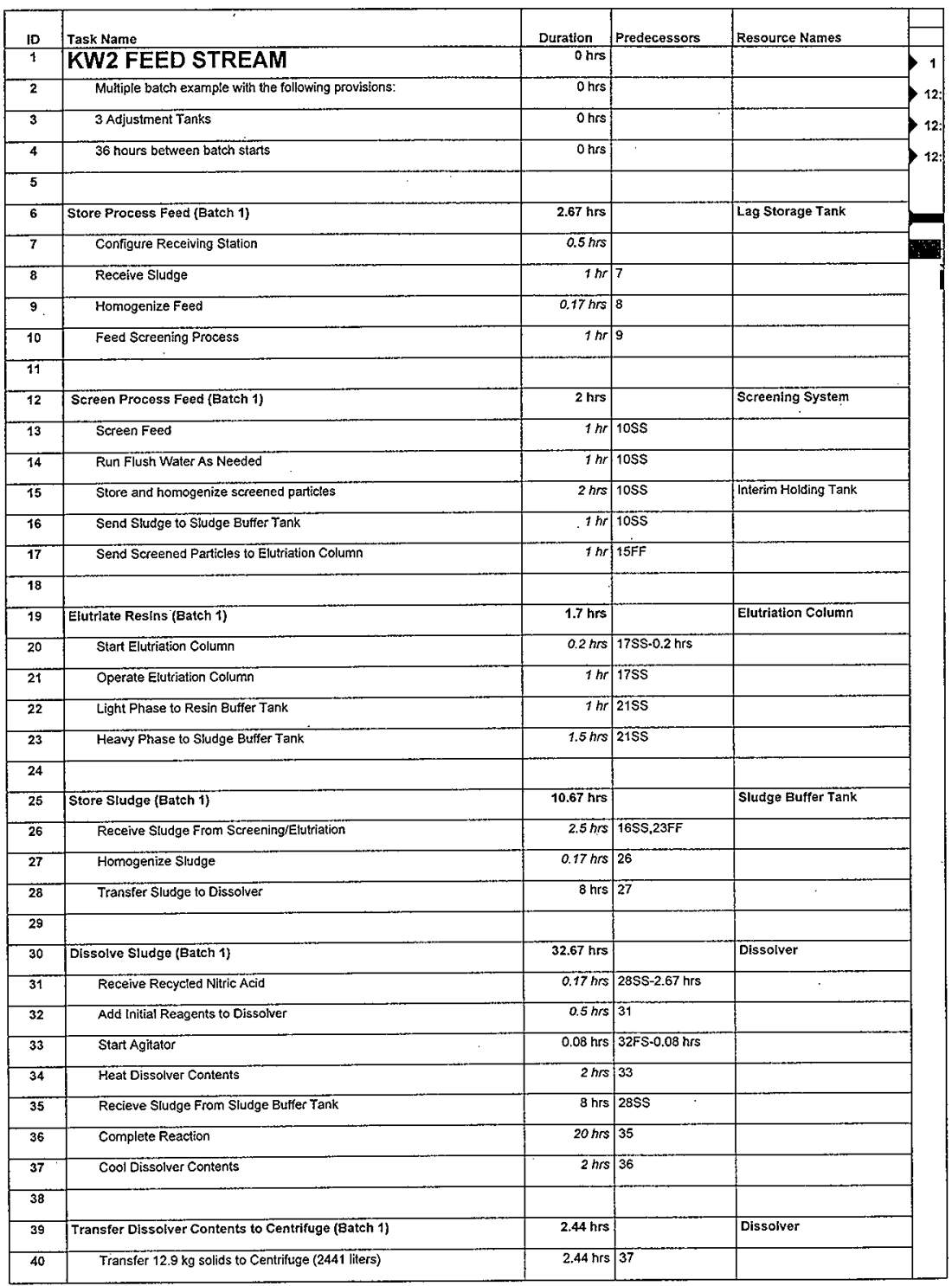


Figure C-8 -- KW2 Process Steps for 3 Adjustment Tank Alternative (cont.)

\begin{tabular}{|c|c|c|c|c|}
\hline ID & Task Name & Duration & Predecessors & Resource Names \\
\hline \multicolumn{5}{|l|}{41} \\
\hline 42 & Centrifuge Dlssolver Products (Batch 1) & $3.27 \mathrm{hrs}$ & & Centrifuge \\
\hline 43 & Start Centrifuge & $0.08 \mathrm{hrs}$ & $40 \mathrm{SS}-0.08 \mathrm{hrs}$ & \\
\hline 44 & Clarify Feed From Dissolver & $2.44 \mathrm{hrs}$ & 40ss & \\
\hline 45 & Transfer Liquids to Clarified Liquid Tank & $2.44 \mathrm{hrs}$ & $44 \$ S$ & \\
\hline 46 & Stop Centrifuge When Clarification Complete & $0.08 \mathrm{hrs}$ & 44 & \\
\hline 47 & Flush Solids Cake With Water (60 liters) & $0,08 \mathrm{hrs}$ & 46 & \\
\hline 48 & Homogenize Solids Cake and Water & $0.08 \mathrm{hrs}$ & 47 & \\
\hline 49 & Recentrifuge Homogenized Slumy & $0.17 \mathrm{hrs}$ & 48 & \\
\hline 50 & Transter Liquids to Clarified Liquid Tank & $0.17 \mathrm{hrs}$ & 4958 & \\
\hline 51 & Flush Solds Cake With Water (60 liters) & 0.08 hrs & 50 & \\
\hline 52 & Homogenize Solids Cake and Water & 0.08 hrs & 51 & \\
\hline 53 & Transfer Solution to Leaching Tank & $0.08 \mathrm{hrs}$ & 52 & \\
\hline 54 & Prepare Centrifuge for more feed & $0.08 \mathrm{hrs}$ & 53 & \\
\hline \multicolumn{5}{|l|}{55} \\
\hline 56 & Leach Rinsed Dissolver Solids (Batch 9) & $4.58 \mathrm{hrs}$ & & Leaching Tank \\
\hline 57 & Receive Centrifuged Dissolver Slurry & $0.08 \mathrm{hrs}$ & $53 S$ & . \\
\hline 58 & Add Leaching Reagents & $0.5 \mathrm{hrs}$ & 57 & \\
\hline 59 & Homogenize Slumy to Aid Leaching & $4 \mathrm{hrs}$ & 58 & \\
\hline \multicolumn{5}{|l|}{60} \\
\hline 61 & Transfer Leached Dissolver Slurry to Centrifuge (Batch 1) & $0.25 \mathrm{hrs}$ & & Leaching Tank \\
\hline 62 & Transfer $12.2 \mathrm{~kg}$ solids to Centrifuge (245 liters) & 0.25 hrs & 59 & \\
\hline \multicolumn{5}{|l|}{63} \\
\hline 64 & CentrIfuge Leached Dlssolver Slurry (Batch 1) & $1.1 \mathrm{hrs}$ & & Centrifuge \\
\hline 65 & Start Centifiuge & $0.08 \mathrm{hrs}$ & $62 \mathrm{Ss}-0.08 \mathrm{hrs}$ & \\
\hline 66 & Clarify Feed From Leaching Tank & $0.25 \mathrm{hs}$ & $62 S S$ & \\
\hline 67 & Transfer Liquids to Clarified Liquid Tank & $0.25 \mathrm{hrs}$ & $665 S$ & \\
\hline 68 & Stop Centrifuge When Clarification Complete & $0.08 \mathrm{hrs}$ & 66 & \\
\hline 69 & Flush Solids Cake With Water (60 liters) & $0.08 \mathrm{hrs}$ & 68 & \\
\hline 70 & Homogenize Solids Cake and Water & $0.08 \mathrm{hrs}$ & 69 & \\
\hline 71 & Recentrifuge Homogenized Stumy & $0.17 \mathrm{hrs}$ & 70 & \\
\hline 72 & Transfer Liquids to Clarified Liquid Tank & $0.17 \mathrm{hrs}$ & $71 S S$ & \\
\hline 73 & Flush Solids Cake With Water (75 liters) & $0.1 \mathrm{hrs}$ & 72 & \\
\hline 74 & Homogenize Solids Cake and Water & $0.08 \mathrm{hrs}$ & 73 & \\
\hline 75 & Transfer Solution to Solids Reception Tank & $0.08 \mathrm{hrs}$ & 74 & \\
\hline 76 & Prepare Centrifuge for more teed & $0.08 \mathrm{hrs}$ & 75 & \\
\hline \multicolumn{5}{|l|}{77} \\
\hline 78 & Store Clarifled Liquid (Batch 1) & B.81 hrs & & Clarifted Llquld Tark \\
\hline 79 & Receive Clarified Dissolver Liquids From Centrifuge & $2.44 \mathrm{hrs}$ & $45 S S$ & \\
\hline 80 & Receive Wash Liquids From Centrifuge & $0.17 \mathrm{hrs}$ & 50 SS & \\
\hline
\end{tabular}


Figure C-8 -- KW2 Process Steps for 3 Adjustment Tank Alternative (cont.)

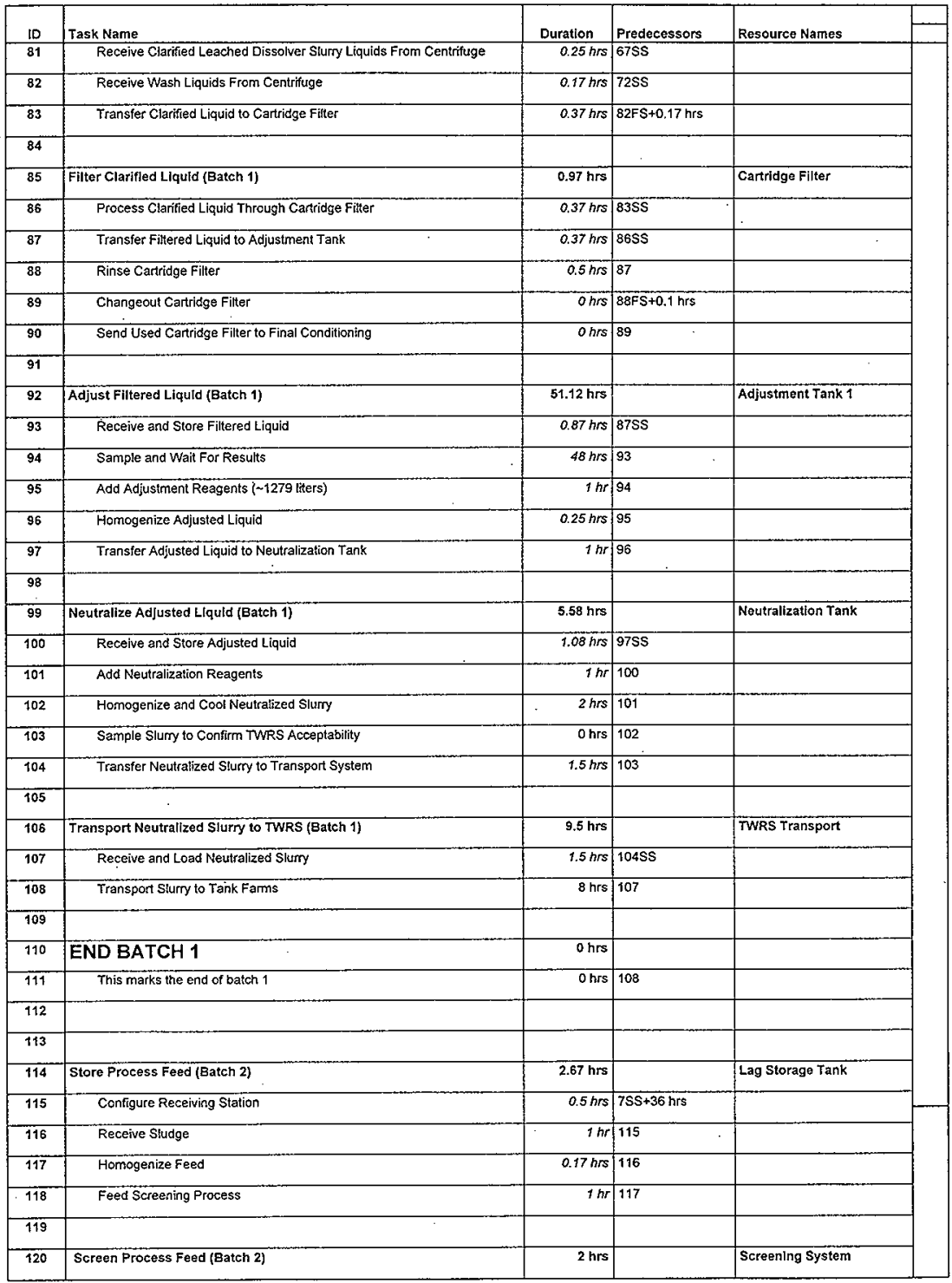




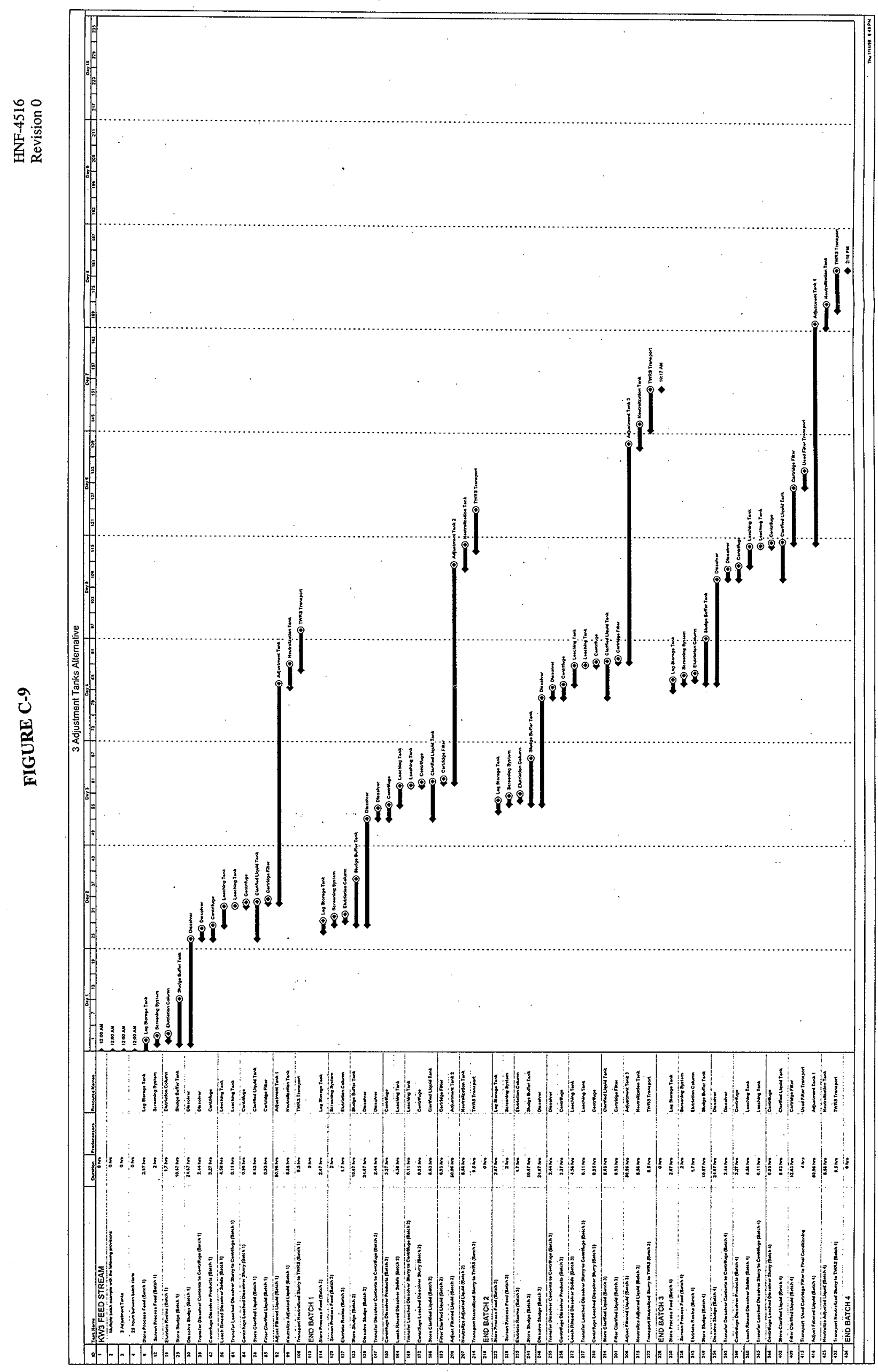


Figure C-10 -- KW3 Process Steps for 3 Adjustment Tank Alternative

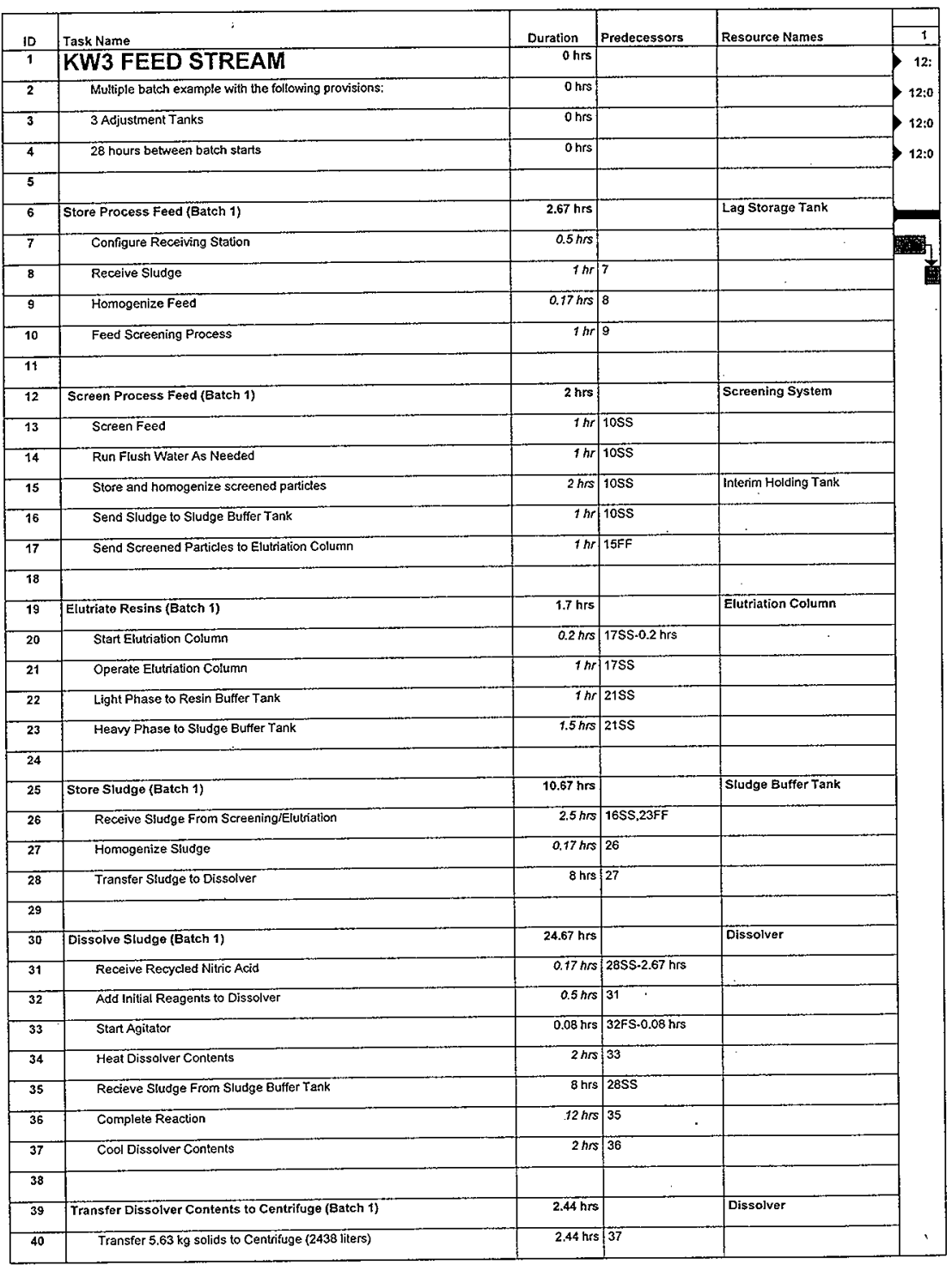


Figure C-10 -- KW3 Process Steps for 3 Adjustment Tank Alternative (cont.)

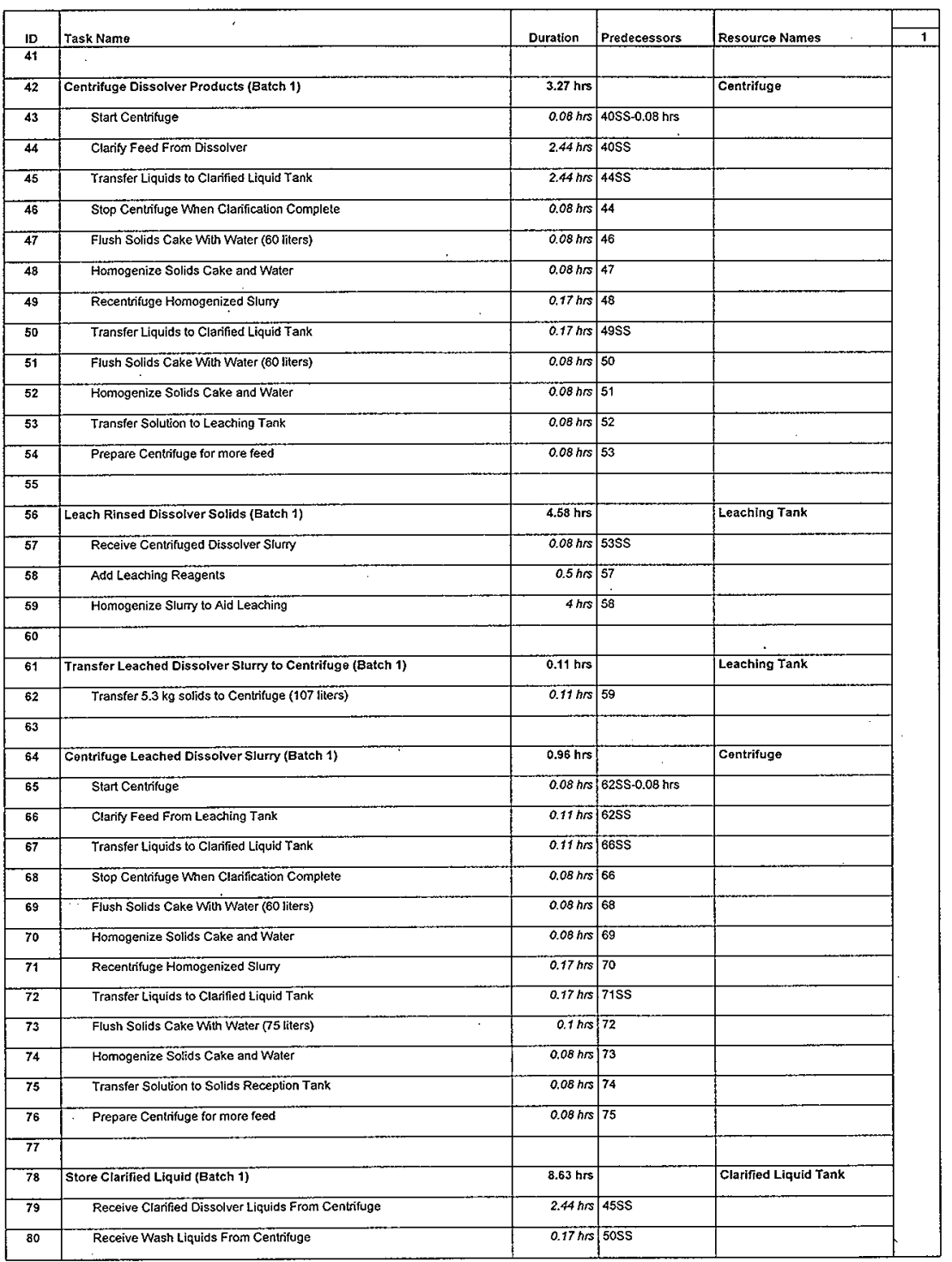


Figure C $-10-$ KW3 Process Steps for 3 Adjustment Tank Alternative (cont.)

\begin{tabular}{|c|c|c|c|c|c|}
\hline ID & Task Name & Duration & Predecessors & Resource Names & 1 \\
\hline 81 & . Receive Clatified Leached Dissoiver Slurry Liquids From Centrifuge & $0.11 \mathrm{hrs}$ & $67 \$ \$$ & & \\
\hline 82 & Receive Wash Liquids From Centrifuge & $0.17 \mathrm{hrs}$ & $72 S S$ & & \\
\hline 83 & Transfer Clarified Liquid to Cartridge Fitter & $0.33 \mathrm{hrs}$ & $82 \mathrm{FS}+0.17 \mathrm{hrs}$ & & \\
\hline \multicolumn{5}{|l|}{84} & \\
\hline 85 & Filter Claritied Liquid (Batch 1) & 0.93 hrs & & Cartridge Filler & \\
\hline 86 & Process Clanfied Liquid Through Cartridge Filter & $0.33 \mathrm{hrs}$ & $83 \mathrm{SS}$ & & \\
\hline 87 & Transfer Filtered Liquid to Adjustment Tank & $0.33 \mathrm{hrs}$ & 86SS & & \\
\hline 88 & Rinse Cartritge Filter & $0.5 \mathrm{hrs}$ & 87 & & \\
\hline 89 & Changeoul Cartridge Filter & 0 hrs & $88 \mathrm{FS}+0.1 \mathrm{hrs}$ & & \\
\hline 90 & Send Used Cartridge Filter to Final Conditioning & 0 hrs & 89 & & \\
\hline \multicolumn{5}{|l|}{91} & \\
\hline 92 & Adjust Filtered Liquid (Batch १) & $50.96 \mathrm{hrs}$ & & Adjustment Tank 1 & \\
\hline 93 & Receive and Store Filtered Liquid & $0.83 \mathrm{hrs}$ & $87 S S$ & & \\
\hline 94 & Sample and Wait For Results & 48 hrs & 93 & & \\
\hline 95 & Add Adjustment Reagents ( 1121 liters) & $0.88 \mathrm{hrs}$ & 94 & & \\
\hline 96 & Homogenize Adjusted Liquid & $0.25 \mathrm{hrs}$ & 95 & & \\
\hline 97 & Transfer Adjusted Liquid to Neutralization Tank & $1 \mathrm{hr}$ & 96 & & \\
\hline \multicolumn{5}{|l|}{98.} & \\
\hline 99 & Neutralize Adjusted Liquid (Batch 1) & $5.58 \mathrm{hrs}$ & & Neutralization Tank & \\
\hline 100 & Receive and Store Adjusted Liquid & $1.08 \mathrm{hrs}$ & 97SS & & \\
\hline 101 & Add Neutralization Reagents & $1 \mathrm{hr}$ & 100 & & \\
\hline 102 & Homogenize and Cool Neutralized Slutry & $2 h r s$ & 101 & & \\
\hline 103 & Sample Stumy to Confirm TWRS Acceptability & o hrs & 102 & & \\
\hline 104 & Transfer Neutralized Slurry to Transport System & $1.5 \mathrm{hrs}$ & 103 & & \\
\hline 105 & & $\cdot$ & & & \\
\hline 106 & Transport Neutralized Slurry to TWRS (Batch 1) & $9.5 \mathrm{hrs}$ & & TWRS Transport & \\
\hline 107 & Receive and Load Neutralized Slurty & $1.5 \mathrm{hrs}$ & $104 S S$ & & \\
\hline 108 & Transport Siumy to T ank Fatms & $8 \mathrm{hrs}$ & 107 & & \\
\hline \multicolumn{5}{|l|}{709} & \\
\hline 110 & END BATCH 1 & o hrs & & . & \\
\hline$\uparrow 11$ & This marks the end of batch 1 & 0 hrs & 108 & & \\
\hline \multicolumn{5}{|l|}{112} & \\
\hline \multicolumn{5}{|l|}{113} & \\
\hline 114 & Store Process Feed (Batch 2) & 2.67 hrs & & Lag Storage Tank & \\
\hline 115 & Configure Receiving Station & $0.5 \mathrm{hrs}$ & $7 \mathrm{SS}+28 \mathrm{hrs}$ & & \\
\hline 116 & Receive Sludge & thr & 115 & & \\
\hline 117 & Homogenize Feed & $0.17 \mathrm{hrs}$ & 116 & & \\
\hline 118 & Feed Screening Process & $1 \mathrm{hr}$ & 117 & & \\
\hline \multicolumn{5}{|l|}{119} & \\
\hline 120 & Screen Process Feed (Batch 2) & $2 \mathrm{hrs}$ & & Screening System & \\
\hline
\end{tabular}


HNF-4516

Revision 0

Figure C-11-Excel Spreadsheet Calculation Display

\begin{tabular}{|c|c|c|c|c|c|c|c|c|}
\hline \multicolumn{9}{|c|}{3 Adjustment Tank Alternative } \\
\hline \multicolumn{4}{|c|}{ Heure betwe } & KE1 & KE2 & KW1 & KW/2 & KW/3 \\
\hline \multicolumn{4}{|c|}{ Hours between batch starts } & 21 & 32 & 21 & 36 & 28 \\
\hline \multicolumn{4}{|c|}{ Hours to get batch completely into adjustment tank } & 32 & 40 & 36 & 44 & 36 \\
\hline \multicolumn{4}{|c|}{ Hours until batch is out of adjustment tank } & 81 & 90 & 85 & 94 & 86 \\
\hline \multicolumn{4}{|c|}{ Hours beginning to end for one batch } & 93 & 103 & 98 & 107 & 99 \\
\hline \multirow{2}{*}{\multicolumn{4}{|c|}{$\begin{array}{l}\text { Total Processing Hours Added by Resin Processing } \\
\text { Total Batches for feed stream }\end{array}$}} & 132 & 9 & 0 & 0 & 9 \\
\hline & & & & 146.1 & 24.4 & 11.2 & 10.2 & 22.4 \\
\hline \multicolumn{9}{|c|}{$\begin{array}{l}\text { The following numbers are derived starting with the equation }(n-1)^{*}(\text { time between batch starts })=\text { start of batch } n \\
\text { All values are in hours, and assumes a cleaning every } 10 \text { batches unless otherwise stated. }\end{array}$} \\
\hline \multirow{2}{*}{\multicolumn{2}{|c|}{ Batch 10 start }} & & & & & & & EndTime of \\
\hline & & $\begin{array}{l}\text { Cleaning } \\
\text { Start }\end{array}$ & $\frac{\text { Batch 11 }}{\text { Start }}$ & $\begin{array}{l}\text { Batch } 11 \\
\text { Start without } \\
\text { cleaning }\end{array}$ & $\begin{array}{l}\text { Timeadded } \\
\text { per batch by } \\
\text { cleaning }\end{array}$ & $\begin{array}{l}\text { Now Batch } \\
\text { Start } \\
\text { Equivalent }\end{array}$ & $\begin{array}{l}\text { End Time of } \\
\text { Einal Batch }\end{array}$ & $\begin{array}{l}\text { EinalBatch } \\
\text { Without } \\
\text { Cleaning }\end{array}$ \\
\hline KE1 & 189 & 230 & 254 & 219 & 3.5 & 24.5 & 3780.0 & 3272.1 \\
\hline \multirow{2}{*}{$\begin{array}{l}\text { KE2 } \\
\text { KW1 }\end{array}$} & 288 & 328 & 352 & 320 & 3.2 & 35.2 & 935.7 & 860.8 \\
\hline & 189 & 225 & 249 & 210 & 3.9 & 24.9 & 352.0 & 312.2 \\
\hline \multirow{3}{*}{$\begin{array}{l}\text { KW2 } \\
\text { KW3 }\end{array}$} & 324 & 368 & 392 & 360 & 3.2 & 39.2 & 467.6 & 438.2 \\
\hline & 252 & 288 & 312 & 280 & 3.2 & 31.2 & 775.7 & 707.2 \\
\hline & $\begin{array}{l}\text { Time to } \\
\text { Process } \\
\text { Stream with } \\
\text { Cleaning } \\
\text { (Davs) }\end{array}$ & $\begin{array}{l}\text { Iime to } \\
\text { Process } \\
\text { Stream } \\
\text { without } \\
\text { Cleaning } \\
\text { (Davs) }\end{array}$ & & & & & & \\
\hline \multirow{2}{*}{$\begin{array}{l}\text { KE1 } \\
\text { KE2 }\end{array}$} & 157.5 & 136.3 & & & & & & \\
\hline & 39.0 & 35.9 & & & & & & \\
\hline \multirow{2}{*}{$\begin{array}{l}K E 2 \\
K W 1 \\
K W 12\end{array}$} & 14.7 & 13.0 & & & & & & \\
\hline & 19.5 & 18.3 & & & & & & \\
\hline $\begin{array}{l}\text { KW2 } \\
\text { KW3 }\end{array}$ & 32.3 & 29.5 & & & & & & \\
\hline Total & 263.0 & 232.9 & & & & & & \\
\hline
\end{tabular}


HNF-4516

Revision 0

\section{APPENDIX D}

\section{SUPPORT INFORMATION AND CALCULATION RESULTS FOR THE 3} ADJUSTMENT TANKS AND 2 DISSOLVERS ALTERNATIVE 
This appendix contains the complete set of Microsoft Project produced summary time diagrams for the 3 Adjustment Tanks and 2 Dissolvers Alternative. The summary time diagrams contain the summary process steps for 4 consecutive batches. They do not include the processing of elutriation column light phases, cleaning/maintenance activities, or the grouting processes. Following each summary time diagram is a listing of all process steps for one batch of the same feed stream, their duration and related steps (predecessors), and the particular resources being used during those steps. The summary time diagrams are figures D-1, D-3, D-5, D-7, and D-9. The detailed process step listings are figures D-2, D-4, D-6, D-8, and D-10.

The information obtained from the Microsoft Project models is then summarized in Figure D-11. Figure D-11 contains the Microsoft Excel spreadsheet used for the 3 Adjustment Tanks and 2 Dissolvers Alternative calculations. The top part shows the information gathered from the models, and the middle and bottom parts are the result of the calculations described in Section 5.1 and replicated in Excel. 
Figure D-2 -- KE1 Process Steps for 3 Adj. Tanks \& 2 Dissolver Alternative

\begin{tabular}{|c|c|c|c|c|c|c|}
\hline \multirow[b]{2}{*}{ ID } & \multirow[b]{2}{*}{ Task Name } & \multirow[b]{2}{*}{ Duration } & \multirow[b]{2}{*}{ Predecessors } & \multirow[b]{2}{*}{ Resource Names } & \multirow[b]{2}{*}{1} & \multirow[b]{2}{*}{2} \\
\hline & & & & & & \\
\hline 1 & KE1 FEED STREAM & O hrs & & & \multicolumn{2}{|c|}{ 12:00 AM } \\
\hline 2 & Multiple batch example with the following provisions: & Onis & & & \multirow{5}{*}{$12: 0$} & \\
\hline 3 & 3 Adjustment Tanks, 2 Oissolvers & Ohrs & & & & \\
\hline 4 & 17 hours between batch starts & 0 hrs & & & & \\
\hline \multicolumn{5}{|l|}{5} & & \\
\hline 6 & Store Process Feed (Batch 1) & 2.67 hrs & & Lag Storage Tank & & \\
\hline 7 & Configure Receiving Station & 0.5 hrs & & & & \\
\hline 8 & Receive Sludge & $1 \mathrm{mr}$ & 7 & & & \\
\hline 9 & Hornogenize Feed & $0.17 \mathrm{hrs}$ & 8 & & & \\
\hline 10 & Feed Screening Process & $1 \mathrm{mr}$ & 9 & & & \\
\hline \multicolumn{5}{|l|}{11} & & \\
\hline 12 & Screen Process Feed (Batch 1) & $2 \mathrm{hrs}$ & & Screening System & & \\
\hline 13 & Screen Feed & $1 \mathrm{hr}$ & toss & & & \\
\hline 74 & Run Flush Water As Needed & $1 \mathrm{hr}$ & $10 \mathrm{ss}$ & & & \\
\hline 15 & Store and homogenize screened particles & $2 h r s$ & $10 \mathrm{sS}$ & Intesim Holding Tank & & \\
\hline 16 & Send Studge to Sludge Butfer Tank & $1 \mathrm{hr}$ & 1055 & & & \\
\hline 17 & Send Screened Particles to Elutriation Column & $3 h r$ & $15 \mathrm{FF}$ & & & \\
\hline \multicolumn{5}{|l|}{18} & & \\
\hline 19 & Elutriate Resins (Batch 1) & $1.7 \mathrm{hrs}$ & & Elutriation Column & & \\
\hline 20 & Stant Elutriation Column & $0.2 \mathrm{hrs}$ & 17 SS-0.2 hrs & & & \\
\hline 21 & Operate Elutiation Cofumn & $1 \mathrm{hr}$ & $17 S S$ & & & \\
\hline 22 & Light Phase to Resin Buffer Tank & $3 \mathrm{hr}$ & $21 S s$ & & & \\
\hline 23 & Heavy Phase to Sludge Euffer Tank & $1.5 \mathrm{hrs}$ & 21SS & & & \\
\hline \multicolumn{5}{|l|}{24} & & \\
\hline 25 & Store Sludge (Batch 1) & 10.67 hrs & & Sludge Buffer Tank & & \\
\hline 26 & Recelve Sludge from Screening/Elutriation & $2.5 \mathrm{hrs}$ & $16 S S, 23 F F$ & & & \\
\hline 27 & Homogenize Siudge & $0.77 \mathrm{hrs}$ & 26 & & & \\
\hline .28 & Transier Sludge to Dissoiver & 8 hrs & 27 & & & \\
\hline \multicolumn{5}{|l|}{29} & & \\
\hline 30 & Dissolve Sludge (Batch $t)$ & $16.67 \mathrm{hrs}$ & & Dissolver 1 & & \\
\hline 31 & Receive Recycled Nitric Acio & 0.17 his & $28 \$ \$-2.67 \mathrm{hrs}$ & & & \\
\hline 32 & Add Initial Reagents to Dissolver & 0.5 hrs & 31 & & & \\
\hline $33^{\circ}$ & Start Agitator & $0.08 \mathrm{hrs}$ & 32 FS-0.08 hrs & & & \\
\hline 34 & Heat Dissoiver Contents & $2 \mathrm{hrs}$ & 33 & & & \\
\hline 35 & Recieve Sludge From Sludge Buffer Tank & $8 \mathrm{hrs}$ & $285 S$ & & & \\
\hline 36 & Complete Reaction & $4 \mathrm{hrs}$ & 35 & & & \\
\hline 37 & Cool Dissolver Contents & $2 \mathrm{hrs}$ & 36 & & & \\
\hline \multicolumn{5}{|l|}{38} & & \\
\hline 39 & Transfer Dissolver Contents to Centrifuge (Batch 1) & . $3.88 \mathrm{hrs}$ & & Dissolver 1 & & \\
\hline 40 & Transfer $18 \mathrm{~kg}$ solids to Cen!rifuge (885 liters) & $0.88 \mathrm{hrs}$ & 37 & & & \\
\hline 41 & Transfer $18 \mathrm{~kg}$ solids to Cenlöfuge (885 liters) & $0.88 \mathrm{hrs}$ & 56 & & & \\
\hline 42 & Transfer Remaining Volume to Centrifuge (610 liters) & $0.62 \mathrm{hrs}$ & 67 & & & \\
\hline \multicolumn{5}{|l|}{43} & & \\
\hline 44 & Centrifuge Disssolver Producis (Batch 1) & 4.71 hrs & & Centrifuge & & \\
\hline
\end{tabular}


Figure D-2 -- KE1 Process Steps for 3 Adj. Tanks \& 2 Dissolver Alternative (cont.)

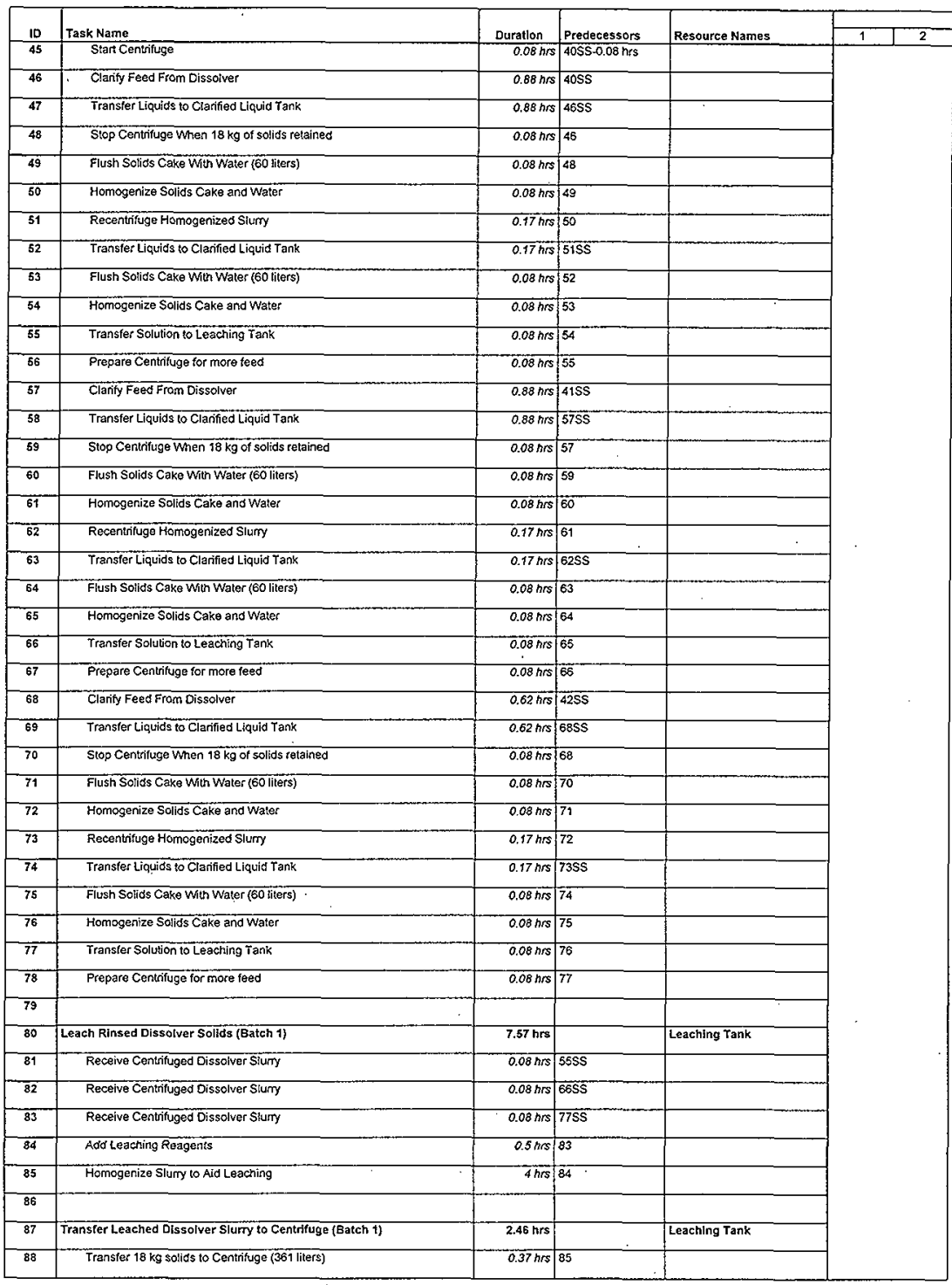


Figure D-2 - KE1 Process Steps for 3 Adj. Tanks \& 2 Dissolver Alternative (cont.)

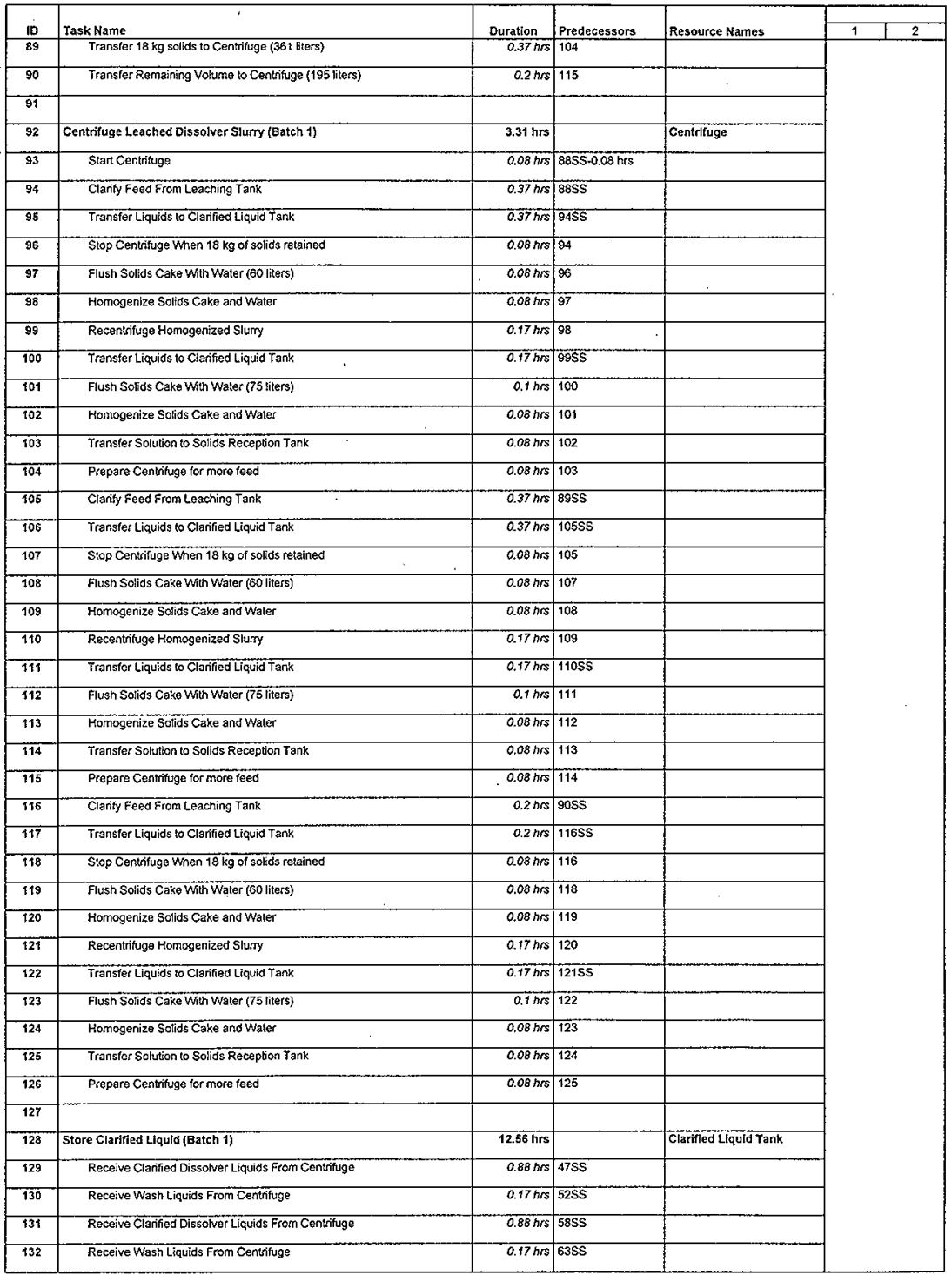


Figure D-2 - KE1 Process Steps for 3 Adj. Tanks \& 2 Dissolver Alternative (cont.)

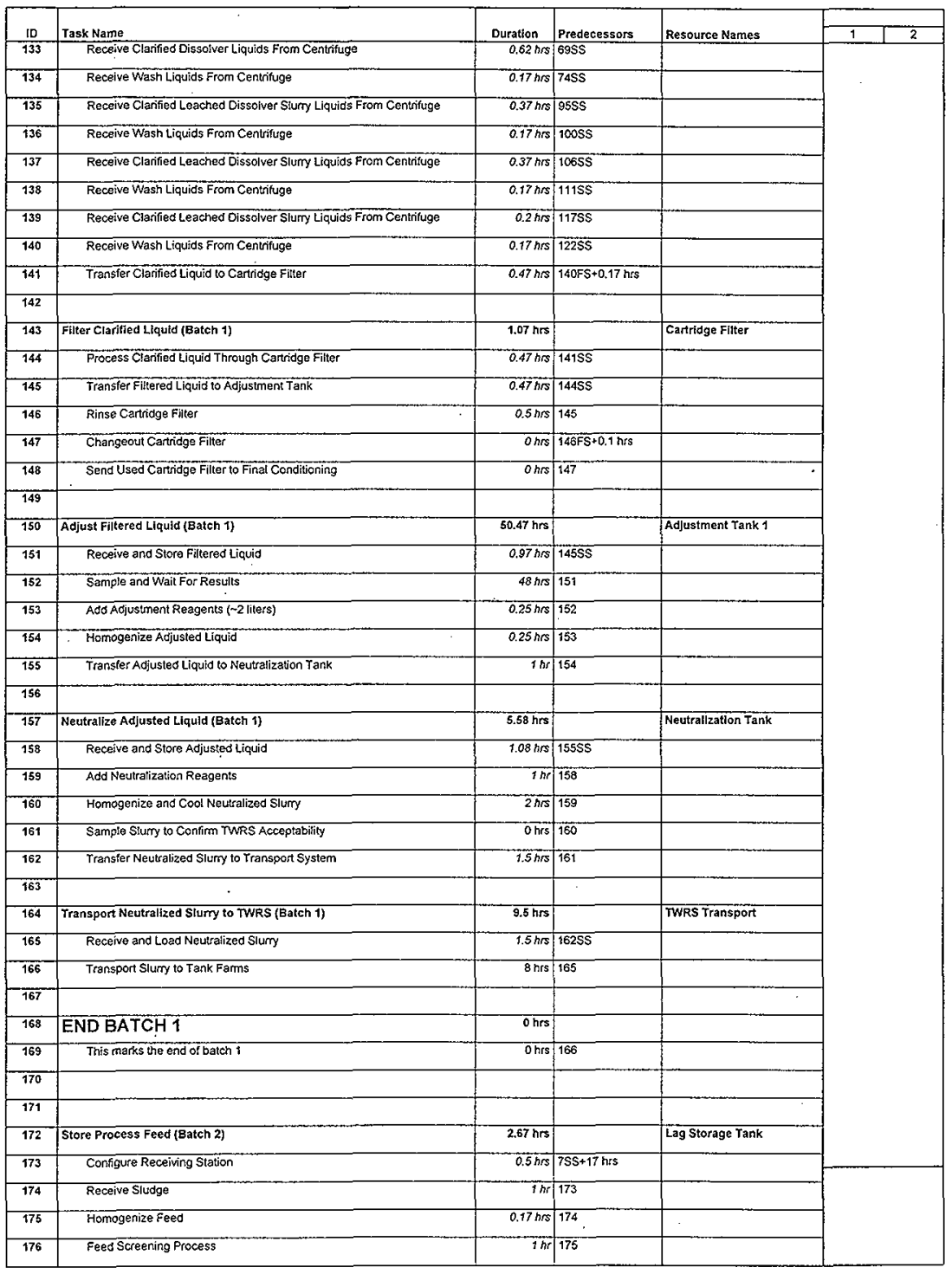




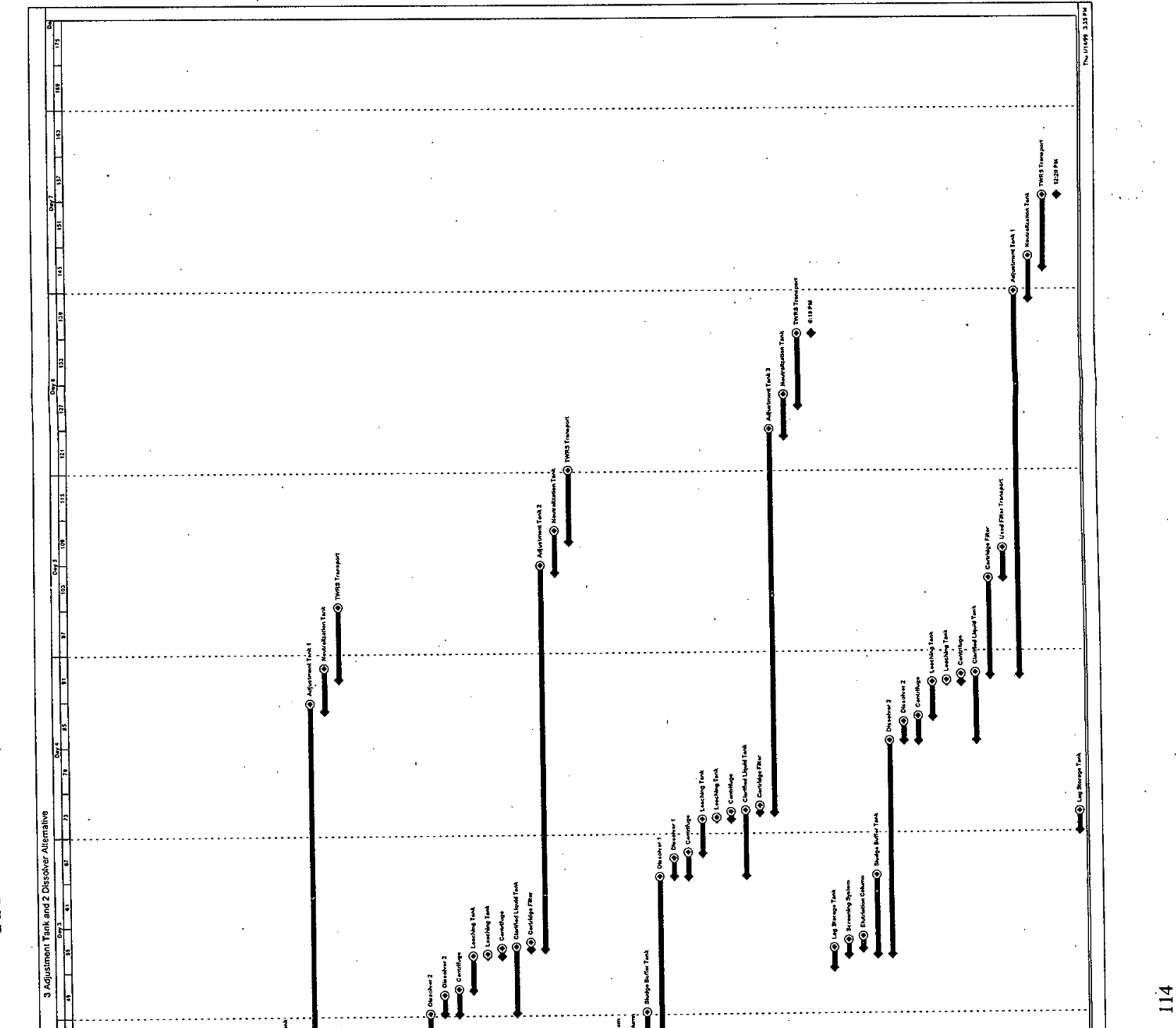


Figure D-4 -- KE2 Process Steps for 3 Adj. Tanks \& 2 Dissolvers Alternative

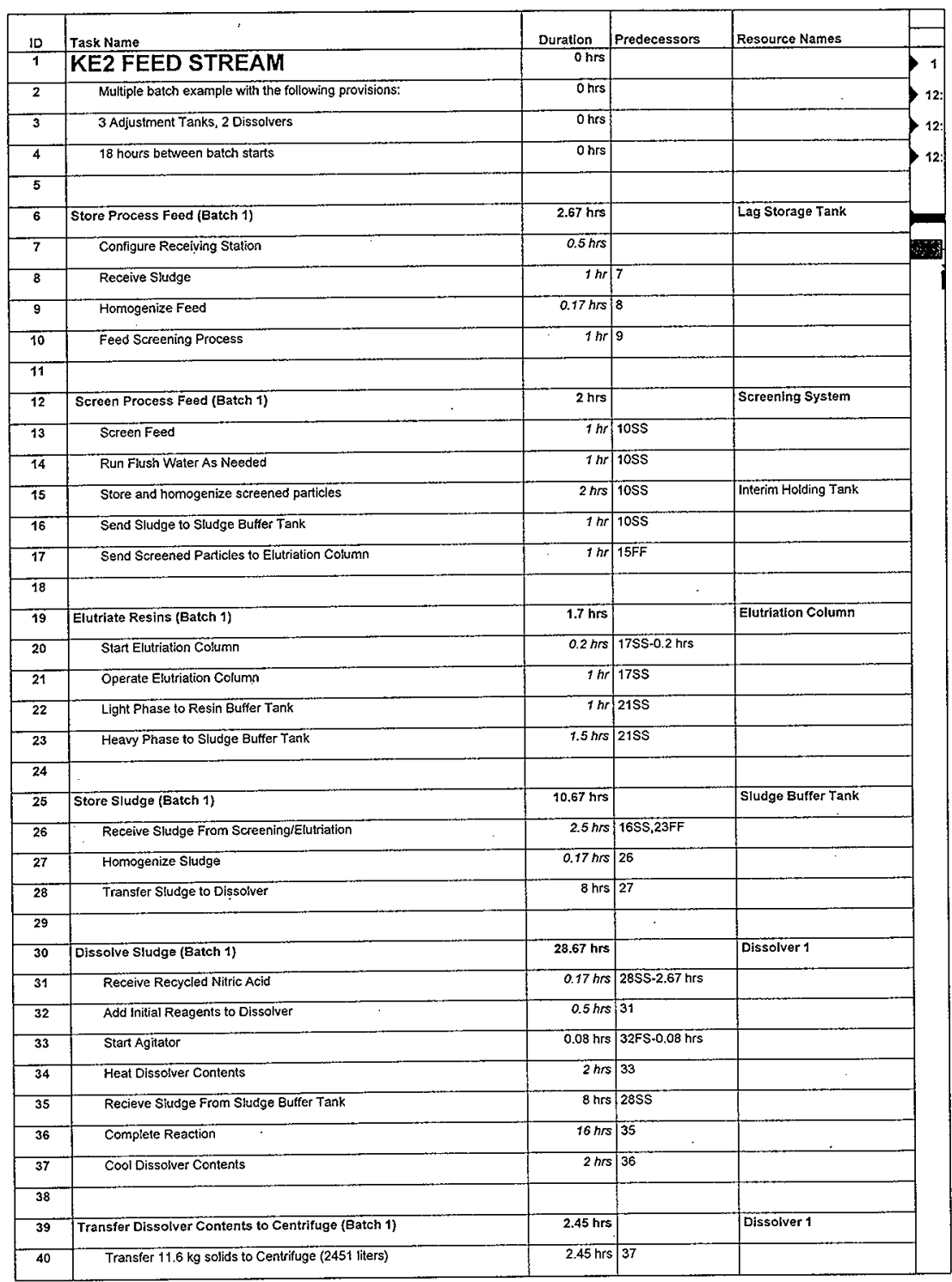


Figure D-4 -- KE2 Process Steps for 3 Adj. Tanks \& 2 Dissolvers Alternative (cont.)

\begin{tabular}{|c|c|c|c|c|}
\hline tD & Task Name & Duration & Predecessors & Resource Names \\
\hline \multicolumn{5}{|l|}{41} \\
\hline 42 & Centrifuge Dissolver Products (Batch 1) & $3.28 \mathrm{hrs}$ & & Centrifuge \\
\hline 43 & Start Centrifuge & $0.08 \mathrm{hrs}$ & 40 SS-0.08 hts & \\
\hline 44 & Clarify Feed From Dissolver & $2.45 \mathrm{hrs}$ & $40 S S$ & \\
\hline 45 & Transter Liquids to Clarified Liquid Tank & $2.45 \mathrm{hrs}$ & $44 S S$ & \\
\hline 46 & Stop Centrifuge When Clarification Complete & $0.08 \mathrm{hrs}$ & 44 & \\
\hline 47 & Fush Solids Cake With Water (60 liters) & $0.08 \mathrm{hrs}$ & 46 & \\
\hline 48 & Homogenize Solids Cake and Water & $0.08 \mathrm{hrs}$ & 47 & \\
\hline 49 & Recentrifuge Homogenized Slurry & $0.17 \mathrm{hrs}$ & 48 & \\
\hline 50 & Transfer Liquids to Clarified Liquid Tank & $0.17 \mathrm{hrs}$ & $49 S 5$ & \\
\hline 51 & Flush Solids Cake With Water (60 liters) & $0.08 \mathrm{hrs}$ & 50 & \\
\hline 52 & Homogenize Solids Cake and Water & $0.08 \mathrm{hrs}$ & 51 & . \\
\hline 53 & Transfer Solution to Leaching Tank & $0.08 \mathrm{hrs}$ & 52 & \\
\hline 54 & Prepare Centrifuge for more feed & $0.08 \mathrm{hrs}$ & 53 & \\
\hline \multicolumn{5}{|l|}{55} \\
\hline 56 & Leach Rinsed Dissolver Solids (Batch 1) & $4.58 \mathrm{hrs}$ & & Leaching Tank \\
\hline 57 & Receive Centrifuged Dissolver Slumy & $0.08 \mathrm{hrs}$ & 5355 & \\
\hline 58 & Add Leaching Reagents & $0.5 \mathrm{hrs}$ & 57 & . \\
\hline 59 & Homogenize Slumy to Ald Leaching & $4 \mathrm{hrs}$ & 58 & \\
\hline \multicolumn{5}{|l|}{60} \\
\hline 61 & Transfer Leached Dissolver Siurry to Centrifuge (Batch 1) & 0.22 hrs & & Leaching Tank \\
\hline 62 & Transfer $10.9 \mathrm{~kg}$ solids to Centrifuge (2.18 liters) & $0.22 \mathrm{hrs}$ & 59 & 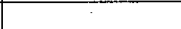 \\
\hline \multicolumn{5}{|l|}{63} \\
\hline 64 & Centrifuge Leached Dissolver S!urry (Batch 1) & $1.07 \mathrm{hrs}$ & & Centrifuge \\
\hline 65 & Start Centrifuge & $0.08 \mathrm{hrs}$ & $62 \mathrm{SS}-0.08 \mathrm{hrs}$ & \\
\hline 66 & Clarify Feed From Leaching Tank & $0.22 \mathrm{hrs}$ & 625 & \\
\hline 67 & Transfer Liquids to Clarified Liquid Tank & $0.22 \mathrm{hrs}$ & $66 S S$ & - \\
\hline 68 & Stop Centrifuge When Clarification Complete & $0.08 \mathrm{hrs}$ & 66 & \\
\hline 69 & Flush Solids Cake With Water (60 liters) & $0.08 \mathrm{hrs}$ & 68 & \\
\hline 70 & Homogenize Solids Cake and Water & $0.08 \mathrm{hrs}$ & 69 & \\
\hline 71 & Recentrifuge Homogenized Slurry & $0.17 \mathrm{hrs}$ & 70 & \\
\hline 72 & Transfer Liquids to Clarified Liquid Tank & $0.17 \mathrm{hrs}$ & $71 \$ 5$ & \\
\hline 73 & Flush Solids Cake With Water (75 liters) & $0.1 \mathrm{hrs}$ & 72 & \\
\hline 74 & Homogenize Solids Cake and Water & $0.08 \mathrm{hrs}$ & 73 & \\
\hline 75 & Transfer Solution to Solids Reception Tank & $0.08 \mathrm{hrs}$ & 74 & \\
\hline 76 & Prepare centrifuge for more feed & $0.08 \mathrm{hrs}$ & 75 & \\
\hline \multicolumn{5}{|l|}{77} \\
\hline 78 & Store Clarified Liquid (Batch 1) & $8.78 \mathrm{hrs}$ & & Clarified Liquid Tank \\
\hline 79 & Receive Clarified Dissolver Liquids From Centrifuge & $2.45 \mathrm{hrs}$ & $45 S$ & \\
\hline 80 & Receive Wash Liquids From Centrifuge & $0.17 \mathrm{hrs}$ & $50 \$ 5$ & \\
\hline
\end{tabular}


Figure D-4 -- KE2 Process Steps for 3 Adj. Tanks \& 2 Dissolvers Alternative (cont.)

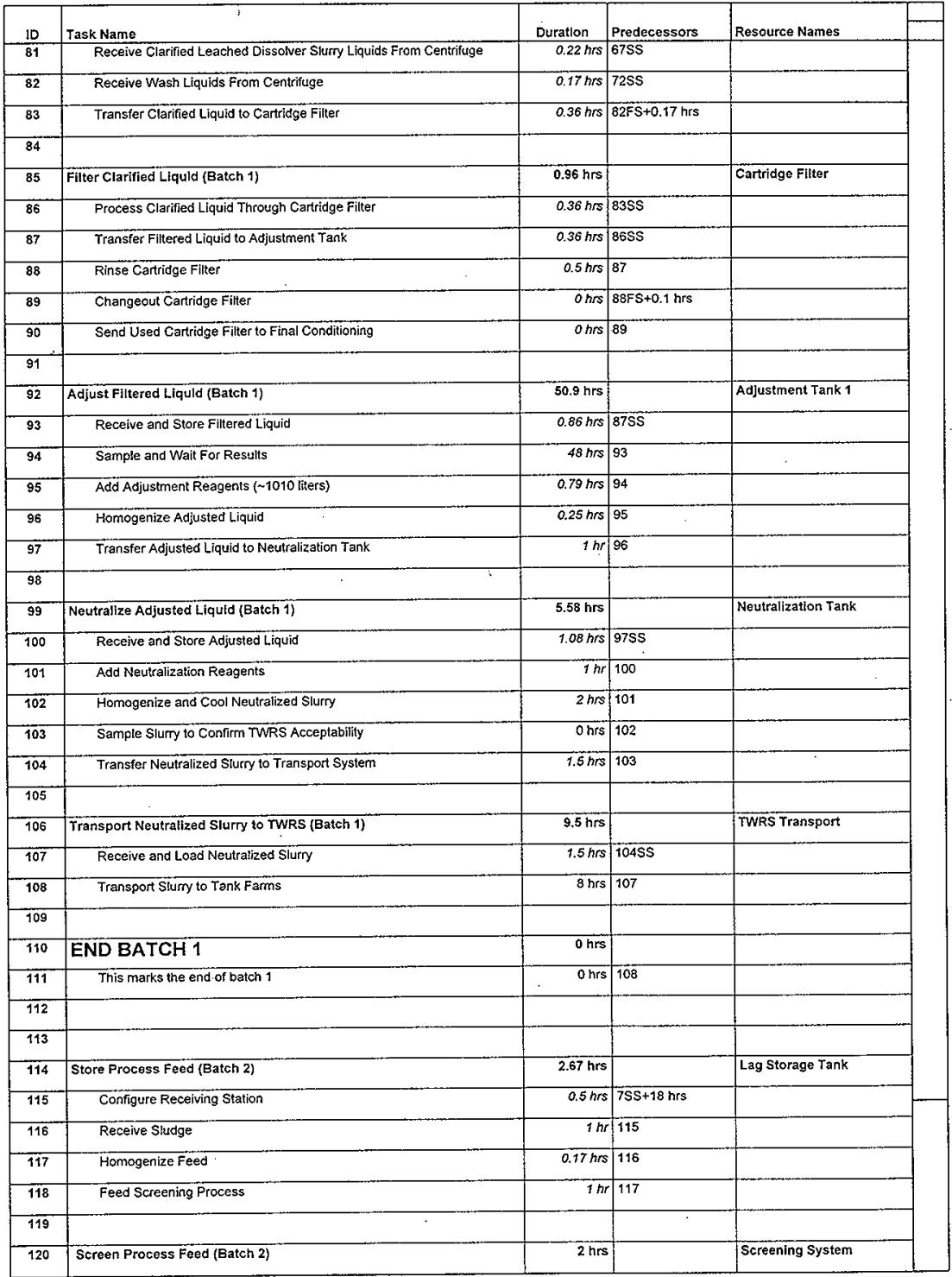




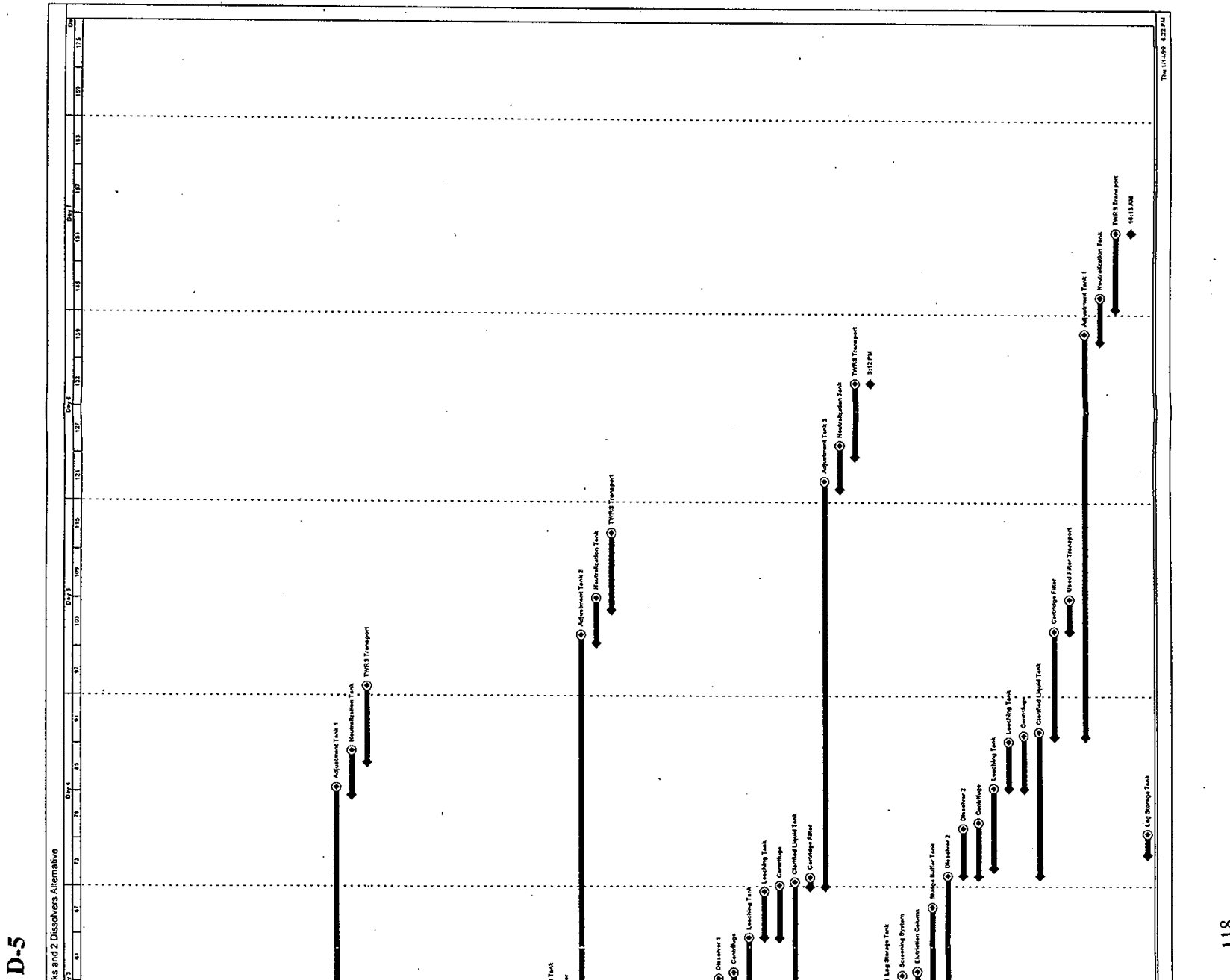


Figure D-6 -- KW1 Process Steps for 3 Adj. Tanks \& 2 Dissolvers Alternative

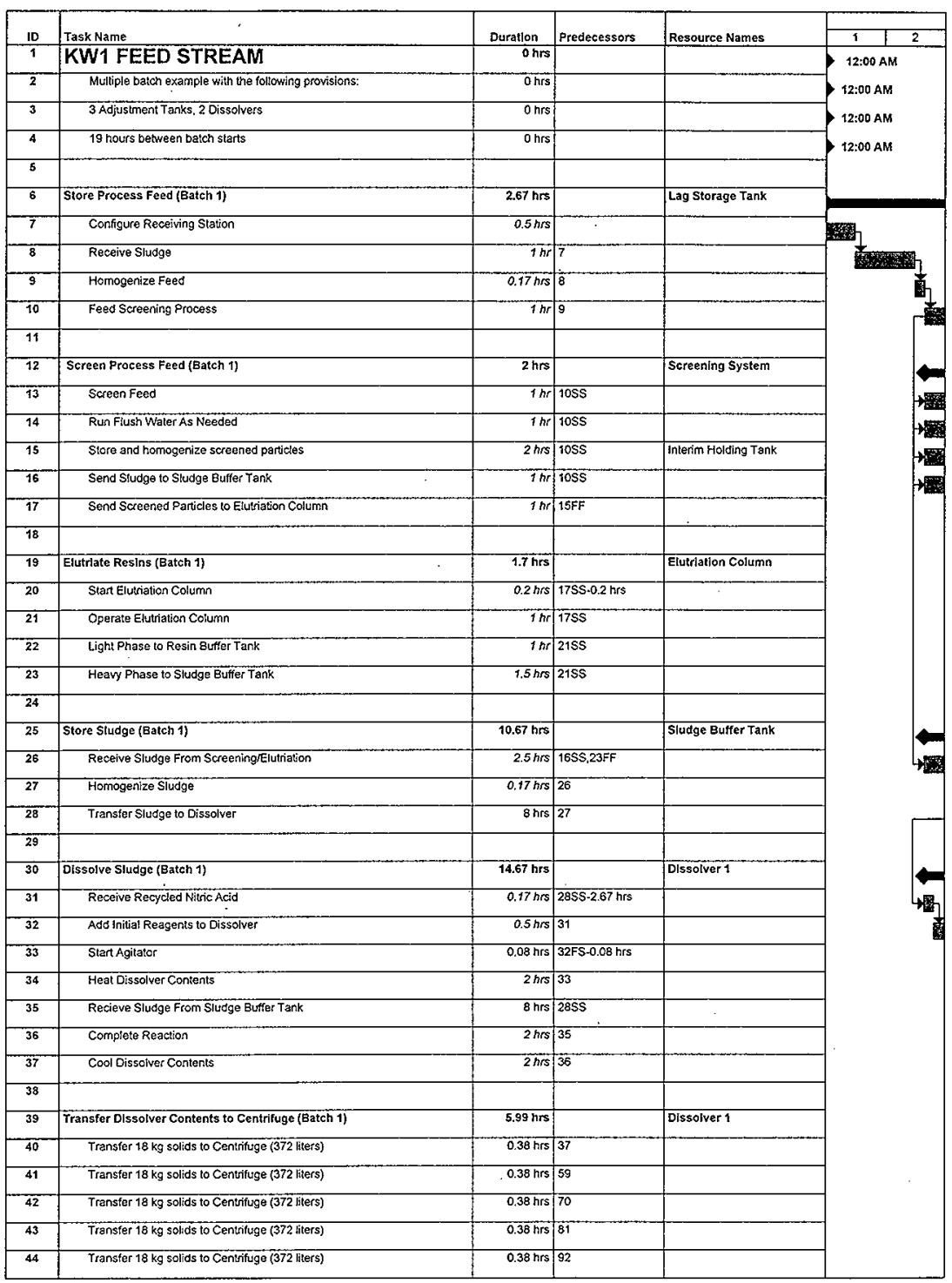


Figure D-6 -- KW1 Process Steps for 3 Adj. Tanks \& 2 Dissolvers Alternative (cont.)

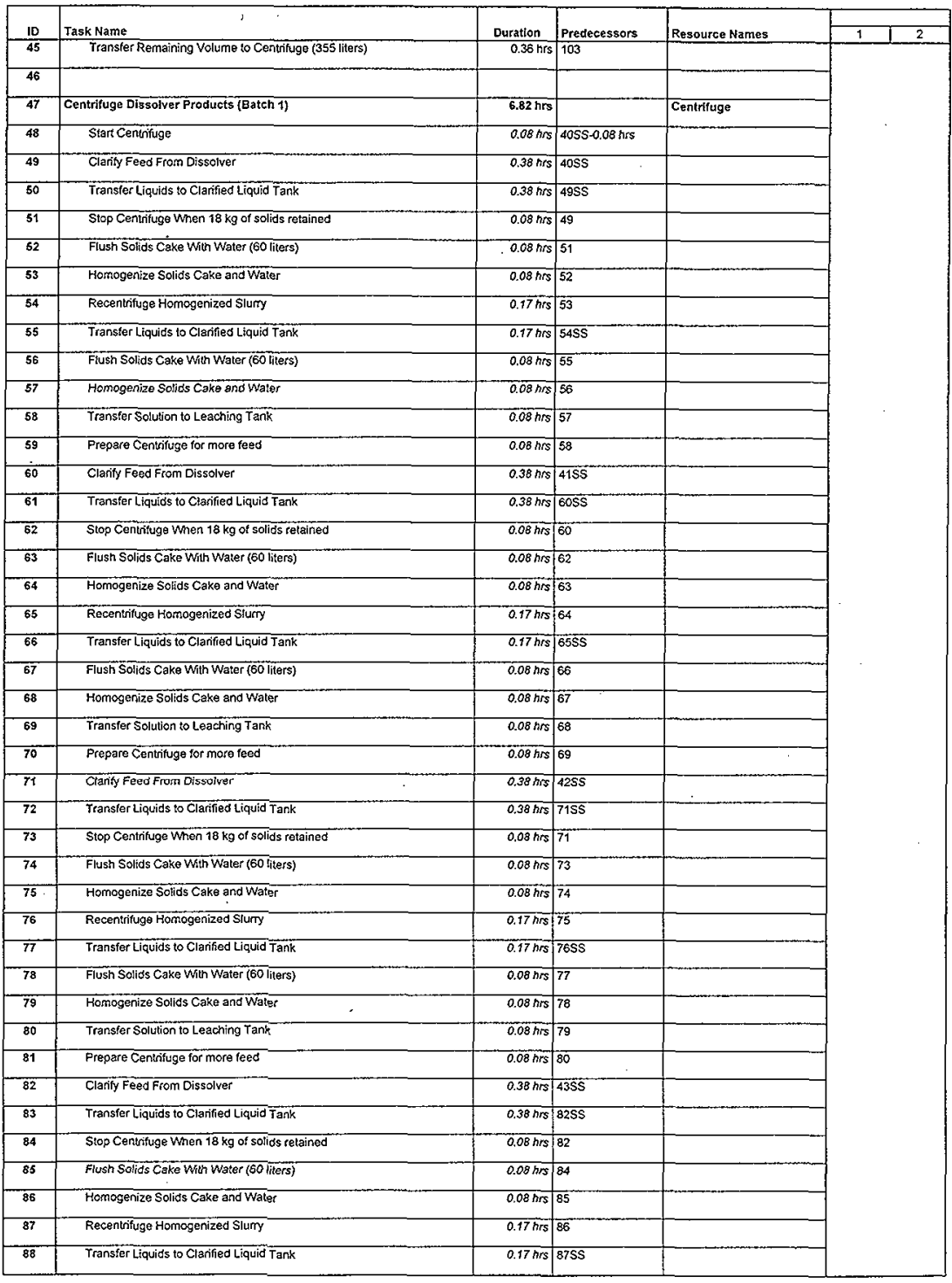


Figure D-6 -- KW1 Process Steps for 3 Adj. Tanks \& 2 Dissolvers Alternative (cont.)

\begin{tabular}{|c|c|c|c|c|c|c|}
\hline ID & Task Name & Duration & Predecessors & Resource Names & 1 & 2 \\
\hline 89 & Flush Solids Cake With Water (80 liters) & $0.08 \mathrm{hrs}$ & 88 & & & \\
\hline 90 & Homogenize Solids Cake and Waler & $0,08 \mathrm{hrs}$ & 89 & & & \\
\hline 91 & Transfer Solution to Leaching Tank & $0.08 \mathrm{hrs}$ & 90 & & & \\
\hline 92 & Prepare Centrifuge for more feed & $0.08 \mathrm{hrs}$ & 91 & & & \\
\hline 93 & Clarify Feed From Dissoiver & $0.38 \mathrm{hrs}$ & 44SS & & & \\
\hline 94 & Transfer Liquids to Clarified Liquid Tank & $0.38 \mathrm{hrs}$ & 9355 & & & \\
\hline 95 & Stop Centriftuge When $18 \mathrm{~kg}$ of solids retained & $0.08 \mathrm{hrs}$ & 93 & & & \\
\hline 96 & Flush Solids Cake With Water (60 liters) & $0.08 \mathrm{hrs}$ & 95 & & & \\
\hline 97 & Homogenize Sofids Cake and Water & $0.08 \mathrm{hrs}$ & 96 & & & \\
\hline 98 & Recentrifuge Homogenized Siumy & $0.77 \mathrm{hrs}$ & 97 & & & \\
\hline 99 & Transter Liquids to Clarified Liquid Tank & $0.17 \mathrm{hrs}$ & 9855 & & & \\
\hline 100 & Flush Solids Cake With Water (60 liters) & $0.08 \mathrm{hrs}$ & 99 & & & \\
\hline 101 & Homcgenize Sclids Cake and Water & $0.08 \mathrm{hrs}$ & 100 & & & \\
\hline 102 & Transfer Solution to Leaching Tank & 0.08 hrs & 101 & & & \\
\hline 103 & Prepare Centrifuge for more feed & $0.08 \mathrm{hrs}$ & 102 & . & & \\
\hline 104 & Clarify Feed From Dissolver & $0.36 \mathrm{hrs}$ & 45SS & & & \\
\hline 105 & Transfer Liquids to Clanifed Liquid Tank & $0.36 \mathrm{hrs}$ & 104SS & & v & \\
\hline 108 & Stop Centrifuge When $18 \mathrm{~kg}$ of solids retained & $0.08 \mathrm{hrs}$ & 104 & & & \\
\hline 107 & Flush Solids Cake With Water (60 liters) & $0.08 \mathrm{hrs}$ & 108 & & & \\
\hline 108 & Homogenize \$olids Cake and Water & $0.08 \mathrm{nrs}$ & 107 & & & \\
\hline 109 & Recentrifuge Homogenized Slumy & $0.17 \mathrm{hrs}$ & 108 & & & \\
\hline 110 & Transfer Liquids to Clańfied Liquid Tank & $0.17 \mathrm{hrs}$ & 10955 & & & \\
\hline 111 & Fiush Solids Cake With Water (60 liters) & $0.08 \mathrm{hrs}$ & 110 & & & \\
\hline 112 & Homogenize Solsds Cake and Water & $0.08 \mathrm{hrs}$ & 111 & & & \\
\hline 113 & Transfer Solution to Leaching Tank & $0.08 \mathrm{hrs}$ & 112 & & & \\
\hline 114 & Prepare Centrifuge for moro feed & $0.08 \mathrm{hrs}$ & 113 & & & \\
\hline \multicolumn{7}{|l|}{115} \\
\hline 116 & Leach Rinsed Dissolver Sollds (Batch 1) & $10.19 \mathrm{hrs}$ & & Leaching Tank & & \\
\hline 117 & Recoive Centrifuged Oissolver Slumy & $0.08 \mathrm{hrs}$ & 585 & & & \\
\hline 118 & Receive Centifuged Dissoiver Slury & $0.08 \mathrm{hrs}$ & $69 \$ 5$ & & & \\
\hline 119 & Receive Centrifuged Dissolver Slumy & $0.08 \mathrm{hrs}$ & $80 S S$ & & & . \\
\hline 120 & Receive Cenvifuged Dissolver Slumy & $0.08 \mathrm{hrs}$ & $915 S$ & & & \\
\hline$\overline{121}$ & Receive Centratuged Dissolver Slurry & $0.08 \mathrm{hrs}$ & $1025 \mathrm{~S}$ & & & \\
\hline 122 & Receive Centriluged Dissolver Slurry & $0.08 \mathrm{hrs}$ & 11358 & & & \\
\hline 123 & Add Leaching Reagents & $0.5 \mathrm{hrs}$ & 122 & . & & \\
\hline 124 & Homogenize Slumy to Aid Leaching & $4 \mathrm{hrs}$ & 123 & & & \\
\hline \multicolumn{7}{|l|}{125} \\
\hline 126 & Transfer Leached Dissolver Sturry to Centrifuge (Batch 1) & $5.85 \mathrm{hrs}$ & & Leaching Tank & & \\
\hline 127 & Transfer $18 \mathrm{~kg}$ solids to Centrifige (360 liters) & $0.36 \mathrm{hrs}$ & 124 & & & \\
\hline 128 & Transfer $18 \mathrm{~kg}$ solids to Centrifuge (360 itters) & $0.36 \mathrm{hrs}$ & 146 & & & \\
\hline 129 & Transfer $18 \mathrm{~kg}$ solids to Centrifuge ( 360 liters) & $0.36 \mathrm{hrs}$ & 157 & & & \\
\hline 130 & Transfer $18 \mathrm{~kg}$ solids to Centrifuge ( 360 liters) & $0.36 \mathrm{hrs}$ & 168 & & & \\
\hline 131 & Transfer $18 \mathrm{~kg}$ solids to Centrifuge ( 360 liters) & $0.36 \mathrm{hrs}$ & 179 & & & \\
\hline
\end{tabular}


Figure D-6 -- KW1 Process Steps for 3 Adj. Tanks \& 2 Dissolvers Alternative (cont.)

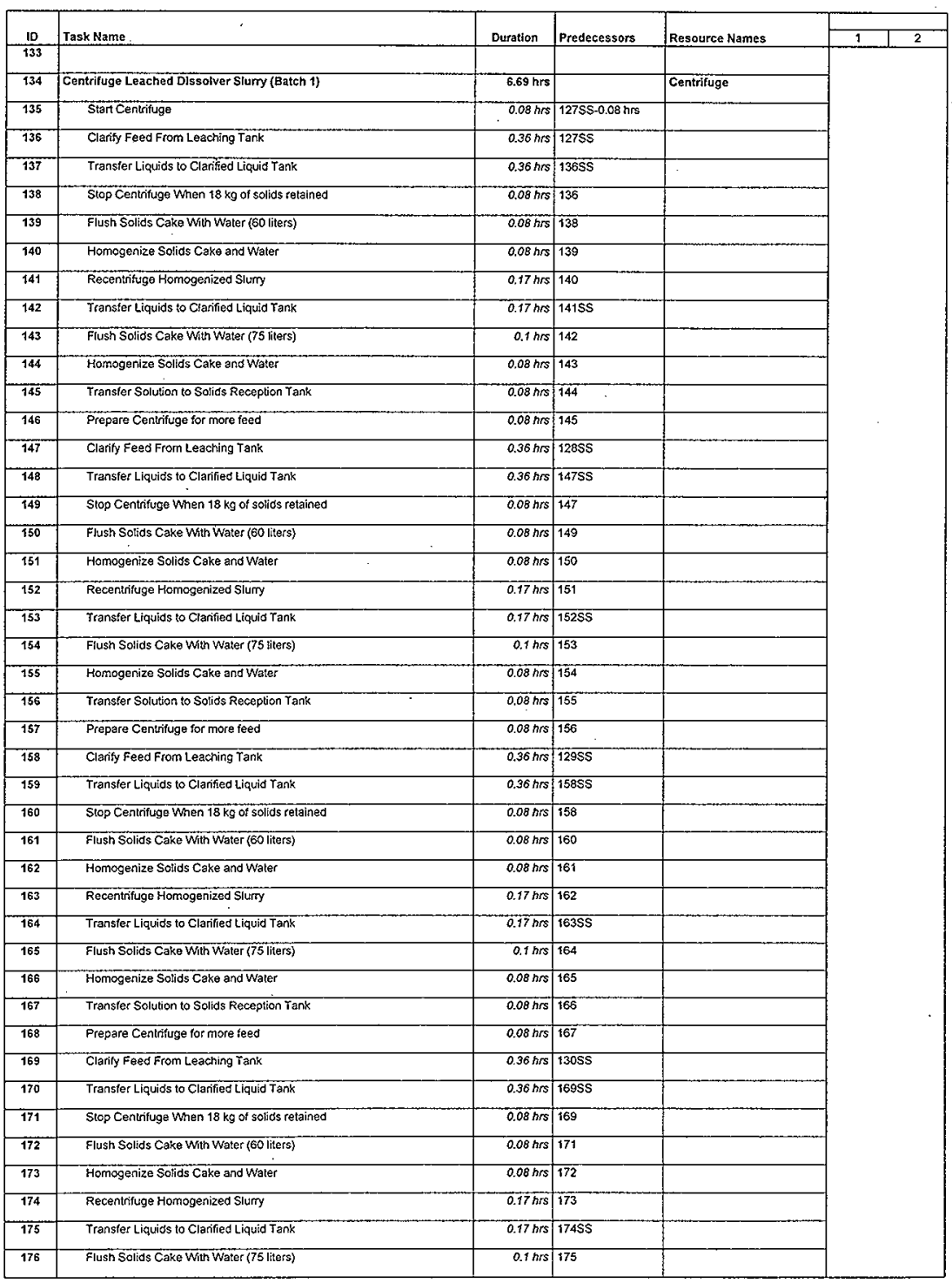


Figure D-6 -- KW1 Process Steps for 3 Adj. Tanks \& 2 Dissolvers Alternative (cont.)

\begin{tabular}{|c|c|c|c|c|c|c|}
\hline ID & Task Name & Duration & Predecessors & Resource Names & 1 & 2 \\
\hline 177 & Homcgenize Solids Cake and Water & $0.08 \mathrm{hrs}$ & 176 & & & \\
\hline 178 & Transfer Solution to Solids Reception Jank & $0.08 \mathrm{hrs}$ & 177 & & & \\
\hline 179 & Prepare Centrifuge for more feed & $0.08 \mathrm{hrs}$ & 178 & . & & \\
\hline 180 & Clanly Feed From Leaching Tank & 0.36 hrs & $1315 \$$ & & & \\
\hline 181 & İrans'er Liquids to Clanified Liquid Tank & $0.36 \mathrm{hrs}$ & $180 \mathrm{SS}$ & & & \\
\hline 182 & Slop Centrifuge When $18 \mathrm{~kg}$ of solids retained & $0.08 \mathrm{hrs}$ & 180 & & & \\
\hline 183 & Fhush Solids Cake With Water (60 liters) & $0.08 \mathrm{hrs}$ & 182 & & & \\
\hline 184 & Homegenize Solids Cake and Water & $0.08 \mathrm{hrs}$ & 183 & & & \\
\hline 185 & Recentrifuge Homogenized slumy & $0.17 \mathrm{hrs}$ & 184 & & & \\
\hline 186 & Transter Liquids to Clarified Liquid Tank & $0.17 \mathrm{hrs}$ & $185 \$ \$$ & & & \\
\hline 187 & Flush Solids Cake Widh Water 776 liters\}) & $0.1 \mathrm{hrs}$ & 186 & & & \\
\hline 188 & Hamogenize Solids Cake and Water & $0.08 \mathrm{hrs}$ & 187 & & & \\
\hline 189 & Transfer Solution to Solids Reception Tank & $0.08 \mathrm{mrs}$ & 188 & & & \\
\hline 190 & Prepare Centrituge for more feed & $0.08 \mathrm{hrs}$ & 189 & & & \\
\hline 191 & Clarify Feed From Leaching Tank & $0.23 \mathrm{hrs}$ & $1325 S$ & & & \\
\hline 192 & Transfer Liquids to Clarified Liquid Tank & $0.23 \mathrm{hrs}$ & $191 \mathrm{SS}$ & & & \\
\hline 193 & Stop Centrifuge When $18 \mathrm{~kg}$ of solids retained & $0.08 \mathrm{hrs}$ & 191 & & & \\
\hline 194 & Flush Solios Cake With Waler (60 liters) & $0.08 \mathrm{hrs}$ & 193 & & & . \\
\hline 195 & Homogenize Solids Cake and Water & $0.08 \mathrm{hrs}$ & 194 & & & \\
\hline 196 & Recentrifuge Homogenized SItumy & $0.17 \mathrm{hrs}$ & 195 & & & \\
\hline 197 & Transfer Liquids to Clarified Liquid Tank & $0.17 h s$ & $196 \$ S$ & & & \\
\hline 198 & Flush Solids Cake With Water (75 liters) & $0.1 \mathrm{hrs}$ & 197 & & & \\
\hline 499 & Homogenize Solids Cake and watet & $0.08 \mathrm{hrs}$ & 198 & & & \\
\hline 200 & Transfer Solution to Solids Reception Tank & 0.08 his & 199 & & & - \\
\hline 201 & Prepare Centrifuge for more feed & $0.08 \mathrm{hrs}$ & 200 & - & & \\
\hline 202 & & & & & & \\
\hline 203 & Store Clariffed Liquid (Batch 1) & $18.2 \mathrm{hrs}$ & & Clarified Llquid Iank & & \\
\hline 204 & Receive Clarified Oissolver Liquids from Centifuge & $0.38 \mathrm{hrs}$ & $50 \mathrm{SS}$ & & & \\
\hline 205 & Receive Wash Liquids From Centrifuge & $0.17 \mathrm{hrs}$ & $55 \$$ & & & \\
\hline 206 & Receive Clanifed Dissolver Liqutids From Centrikuge & $0.38 \mathrm{hrs}$ & $61 \mathrm{SS}$ & & & \\
\hline 207 & Receive Wash Liquids From Centrifuge & $0.17 \mathrm{hrs}$ & $665 S$ & & & \\
\hline 208 & Receive Clanfied Dissolver Liquids From Gentrifutge & 0.38 his & $72 S S$ & & & \\
\hline 209 & Receive Wash Liquids F Fom Centrifuge & $0.17 \mathrm{hrs}$ & $775 S$ & & & \\
\hline 210 & Receive Clarified Dissolyer Liquids From Centrifuge & $0.38 \mathrm{hrs}$ & 83SS & & & \\
\hline 211 & Recaive Wash Liquids From Centrifuge & 0.17 hrs & $88 S S$ & & & \\
\hline $2+2$ & Receive Clarified Dissolver Liquids From Centrifuge & $0.38 \mathrm{hrs}$ & $94 S \$$ & & & \\
\hline 213 & Receive Wash Liquids From Contrifuge & 0.17 hrs & 995 & & & \\
\hline 214 & Receive Clarified Dissolver Liquids From Centrifuge & $0.36 \mathrm{hrs}$ & $1055 S$ & & & \\
\hline 215 & Receive Wash Licuids From Cenuiluge & $0.17 \mathrm{hrs}$ & $110 \mathrm{~s}$ & & & \\
\hline 216 & Receivo Clarifed Leached Dissolver Slutry Liquids From Centrifuge & $0.36 \mathrm{hrs}$ & 137SS & & & \\
\hline 217 & Receive Wash Liçuids From Centrituge & $0.17 \mathrm{hrs}$ & 14255 & & & \\
\hline 218 & Receive Clanfied Leached Dissolver Slurry Liquids From Centrifuge & $0.36 \mathrm{hrs}$ & $1485 S$ & & & \\
\hline 219 & Receive Wash Liquids From Centrifuge & $0.17 \mathrm{hrs}$ & $1535 S$ & & & \\
\hline 220 & Receive Clarified Leached Dissolver Sturry Liquids From Centrifuge & $0.36 \mathrm{hrs}$ & 159SS & & & \\
\hline
\end{tabular}


Figure D-6 -- KW1 Process Steps for 3 Adj. Tanks \& 2 Dissolvers Alternative (cont.)

\begin{tabular}{|c|c|c|c|c|c|c|}
\hline \multirow[b]{2}{*}{ ID } & \multirow[b]{2}{*}{ Task Name } & \multirow[b]{2}{*}{ Duration } & \multirow[b]{2}{*}{ Predecessors } & \multirow[b]{2}{*}{ Resource Names } & \multirow[b]{2}{*}{1} & \multirow[b]{2}{*}{2} \\
\hline & & & & & & \\
\hline 221 & Receive Wash Liquids From Centrifuge & $0.17 \mathrm{hrs}$ & $164 S S$ & & & \\
\hline 222 & Receive Clarified Leached Dissolver Slumy Liquids from Centrifuge & $0.36 \mathrm{hrs}$ & $1705 S$ & & & \\
\hline 223 & Receive Wash Liquids From Centrifuge & $0.17 \mathrm{hrs}$ & $175 \mathrm{SS}$ & & & \\
\hline 224 & Receive Clanified Leached Dissolver Slurny Liquids From Centrifuge & $0.36 \mathrm{hrs}$ & 181SS & & & \\
\hline 225 & Receive Wash Liquids From Centrifuge & $0.17 \mathrm{hrs}$ & $1865 S$ & & & \\
\hline 226 & Receive Clanified Leached Dissolver Slurry Liquids From Centrifuge & $0.23 \mathrm{hrs}$ & $192 \mathrm{SS}$ & & & \\
\hline 227 & Receive Wash Liquids From Centiluge & $0.17 \mathrm{hrs}$ & $197 \mathrm{SS}$ & & & \\
\hline 228 & Transfer Clarified Liquid to Cartridge Filter & $0.61 \mathrm{hrs}$ & $227 \mathrm{Fs}+0.17 \mathrm{hts}$ & & & \\
\hline \multicolumn{5}{|l|}{229} & & \\
\hline 230 & Fliter Clarifled Llquid (Batch i) & $1.21 \mathrm{hrs}$ & & Cartridge Filter & & \\
\hline 231 & Process Clasified Liquid Through Cartridge Filter & $0.61 \mathrm{hrs}$ & $2285 S$ & & & \\
\hline 232 & Transfer Filtered Liquid to Adjustment Tank & $0.61 \mathrm{hrs}$ & $2315 S$ & & & \\
\hline 233 & Rinse Cartridge Filter & $0.5 \mathrm{hrs}$ & 232 & & & \\
\hline 234 & Changeout Cartidge Fitter & ohrs & $233 F S+0.1 \mathrm{hrs}$ & & & \\
\hline 235 & Send Used Cantidge Filter to Final Conditioning & onrs & 234 & & & \\
\hline \multicolumn{5}{|l|}{236} & & \\
\hline 237 & Adjust Filtered Llquld (8atch 1) & $60.61 \mathrm{hrs}$ & & Adjustment Tank 1 & & \\
\hline 238 & Receive and Store Filtered Liquid & $1.11 \mathrm{hrs}$ & $232 S S$ & & & \\
\hline 239 & Sample and Wait For Results & $48 \mathrm{hrs}$ & 238 & & & \\
\hline 240 & Add Adjustment Reagents ( -1 liters) & $0.25 \mathrm{nrs}$ & 239 & & & \\
\hline 241 & Homogenize Adjusted Liquid & 0.25 hrs & 240 & & & \\
\hline 242 & Transfer Adjusted Liquid to Neutralization Tank & Thr & 241 & & & \\
\hline \multicolumn{5}{|l|}{243} & & \\
\hline 244 & Neutralize Adjusted Liquid (Batch 1) & 5.58 hrs & & Neutra!lzation Tank & & \\
\hline 245 & Receive and Store Adjusted Liquid & $1.08 \mathrm{nrs}$ & $242 S S$ & & & \\
\hline 246 & Add Neulralization Reagents & Thr & 245 & & & \\
\hline 247 & Homogenize and Cocl Neutralized Slumy & $2 \mathrm{hrs}$ & 246 & & & \\
\hline 248 & Sample Slumy to Confirm TWRS Acceptability & 0 his & 247 & & & \\
\hline 249 & Transfer Neutralized Slurry to Transport System & $1.5 \mathrm{hrs}$ & 248 & & & \\
\hline \multicolumn{5}{|l|}{250} & & \\
\hline 251 & Transport Neutralized Slurry to TWRS (Batch 1) & $9.5 \mathrm{hrs}$ & & TWRS Transport & & \\
\hline 252 & Receive and Load Neutralized Slury & $1.5 \mathrm{hrs}$ & $249 S S$ & & & \\
\hline 253 & Transport Slurry to Tank Farms & $8 \mathrm{hts}$ & 252 & & & \\
\hline \multicolumn{5}{|l|}{254} & & \\
\hline 255 & END BATCH 1 & o hrs & & & & \\
\hline 256 & This marks the end of batch 1 & o hrs & 253 & & & \\
\hline \multicolumn{5}{|l|}{257} & & \\
\hline \multicolumn{5}{|l|}{258} & & \\
\hline 259 & Store Process Feed (Batch 2) & $2.67 \mathrm{hrs}$ & & Lag Storage Tank & & \\
\hline 260 & Configure Receiving Station & $0.5 \mathrm{hrs}$ & $7 S S+19 \mathrm{hrs}$ & & & \\
\hline 261 & Receive Sludge & $1 \mathrm{hr}$ & 260 & & & \\
\hline 262 & Homogenize Feed & $0.17 \mathrm{hrs}$ & 261 & & & \\
\hline 263 & Feed Screening Process & $1 \mathrm{hr}$ & 252 & & & \\
\hline 264 & & & & & & \\
\hline
\end{tabular}




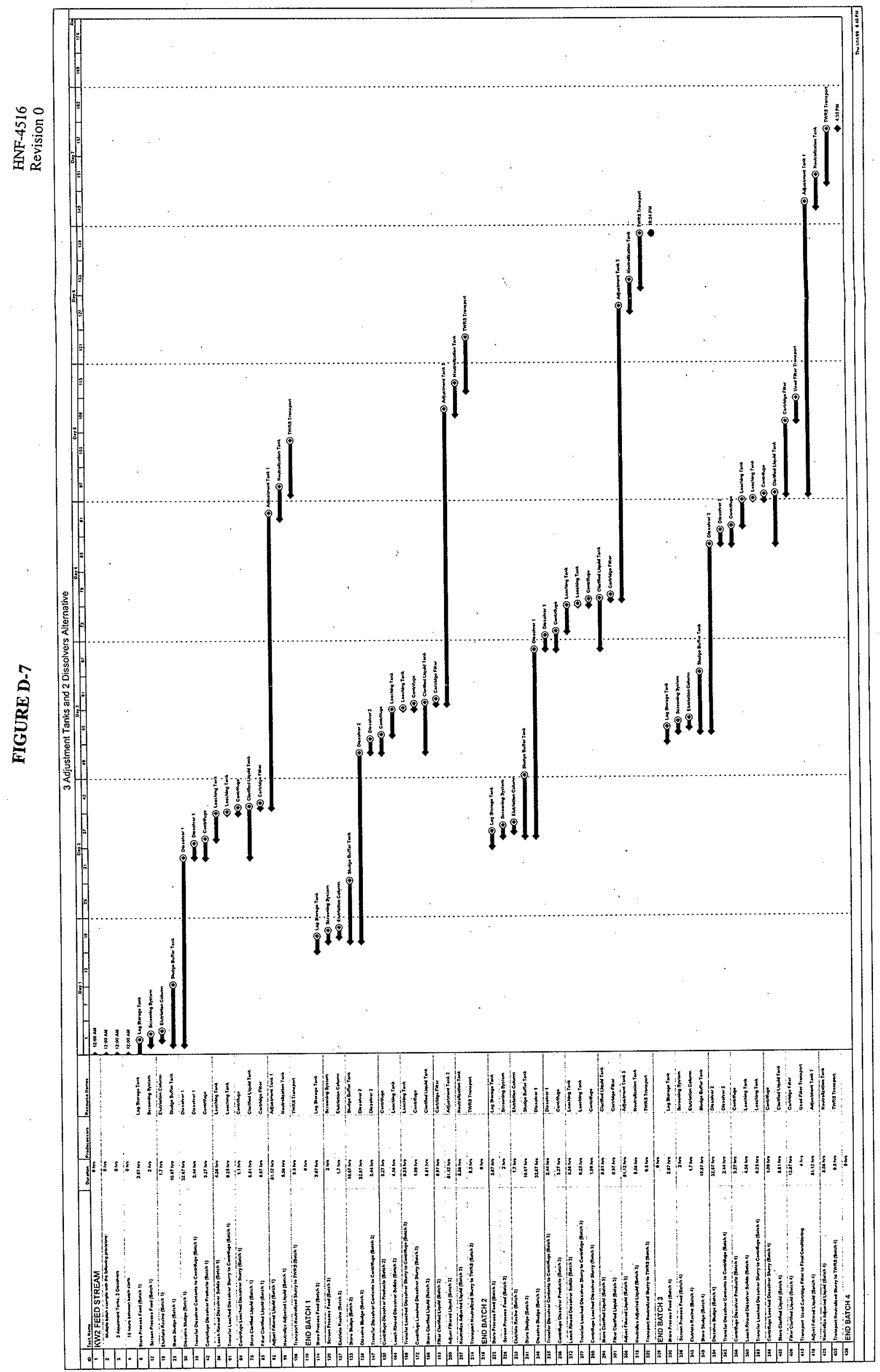


Figure D-8 -- KW2 Process Steps for 3 Adj. Tanks \& 2 Dissolvers Alternative

\begin{tabular}{|c|c|c|c|c|c|}
\hline $1 \mathrm{D}$ & Task Name & Duration & Predecessors & Resource Names & \multirow{2}{*}{$\frac{1}{12: 00 \mathrm{~A}}$} \\
\hline 1 & KW2 FEED STREAM & o hrs & & & \\
\hline 2 & Multiple batch example with the following provisions: & o hrs & & & \\
\hline 3 & 3 Adjustment Tanks, 2 Dissolvers & o hrs & & & \\
\hline 4 & 18 hours bewween batch starts & Ohrs & & & $12: 00 \mathrm{~A}$ \\
\hline \multicolumn{6}{|l|}{5} \\
\hline 6 & Store Pracess Feed (Batch 1) & 2.67 hrs & & Lag Storage Tank & \\
\hline 7 & Configure Receiving Station & $0.5 \mathrm{hrs}$ & & & \\
\hline 8 & Receive Sludge & $1 \mathrm{hr}$ & 7 & & \\
\hline 9 & Homogenize Feed & 0.17 hrs & 8 & ? & \\
\hline 10 & Feed Screening Process & $1 \mathrm{hr}$ & 9 & & \\
\hline \multicolumn{6}{|l|}{11} \\
\hline 12 & Screen Process Feed (Batch $q)$ & $2 \mathrm{hrs}$ & & Screening System & \\
\hline 13 & Screen Feed & $7 \mathrm{hr}$ & 10Ss & & \\
\hline 14 & Run Flush Water As Needed & $7 \mathrm{hr}$ & $105 s$ & & \\
\hline 15 & Store and homogenize screened particles & $2 \mathrm{hrs}$ & $10 \mathrm{sS}$ & Interim Holding Tank & \\
\hline 16 & Send Sludge to Sludge 8uffer Tank & $1 \mathrm{hr}$ & $10 \mathrm{SS}$ & & \\
\hline 17 & Send Screened Particles to Elutriation Column & $1 \mathrm{hr}$ & $15 F F$ & & \\
\hline \multicolumn{6}{|l|}{$\overline{18}$} \\
\hline 49 & Elutriate Resins (Batch $\uparrow$ ) & $1.7 \mathrm{hrs}$ & & Elutriation Column & \\
\hline 20 & Start Elutriation Column & $0.2 \mathrm{hrs}$ & $17 \mathrm{SS}-0.2 \mathrm{hrs}$ & & \\
\hline 21 & Operate Elutriation Column & $1 \mathrm{hr}$ & 1755 & . & \\
\hline 22 & Light Phase to Resin Buffer Tank & $1 \mathrm{hr}$ & $215 s$ & & \\
\hline 23 & Heavy Phase to Sludge Buffer Tank & $1.5 \mathrm{hrs}$ & $21 S S$ & & \\
\hline \multicolumn{6}{|l|}{24} \\
\hline 25 & Store Sludge (Batch 1) & $10.67 \mathrm{hrs}$ & & Sludge Buffer Tank & \\
\hline 26 & Receive Sludge From ScreeningjElutration & $2.5 \mathrm{hrs}$ & $16 S S, 23 F F$ & & \\
\hline 27 & homogenize Sludge & $0.17 \mathrm{hrs}$ & 26 & & \\
\hline 28 & Transfer Sludge to Dissolver & $8 \mathrm{hrs}$ & 27 & & \\
\hline 29 & . & & & & 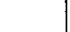 \\
\hline 30 & Dissolve Sludge (Batch 1) & $32.67 \mathrm{hrs}$ & r & Dissolver 1 & \\
\hline 31 & Receive Recycled Nitric Acid & $0.17 \mathrm{hrs}$ & $28 \mathrm{Ss}-2.67 \mathrm{hrs}$ & & \\
\hline 32 & Add initial Reagents to Dissclver & $0.5 \mathrm{hrs}$ & 31 & & \\
\hline 33 & Start Agitator & $0.08 \mathrm{hrs}$ & $32 \mathrm{FS}-0.08 \mathrm{~h} / \mathrm{s}$ & & \\
\hline 34 & Heat Dissolver Contents & $2 h r s$ & 33 & & $\cdot$ \\
\hline 35 & Recieve Sludge From Sludge Buffer Tank & $8 \mathrm{hrs}$ & $28 \$ S$ & & \\
\hline 36 & Complete Reaction & 20 hrs & 35 & & \\
\hline 37 & Cool Dissolver Contents & 2 hrs & 36 & & \\
\hline 38 & & & & . & \\
\hline 39 & Transfer Dissolver Contents to Centrifuge (Batch 1) & $2.44 \mathrm{hrs}$ & & Dissolver 1 & \\
\hline 40 & Transfer $12.9 \mathrm{~kg}$ solids to Centrifuge (2441 liters) & $2.44 \mathrm{hrs}$ & 37 & & \\
\hline 41 & & & & & \\
\hline
\end{tabular}


Figure D-8 - KW2 Process Steps for 3 Adj. Tanks \& 2 Dissolvers Alternative (cont.) Revision 0

\begin{tabular}{|c|c|c|c|c|c|}
\hline ID & Task Name & Duration & Predecessors & Resource Names & 1 \\
\hline 42 & Centrifuge Dissolver Products (Batch 1) & $3.27 \mathrm{hrs}$ & & Centrifuge & \\
\hline 43 & Start Centrifuge & $0.08 \mathrm{hrs}$ & 40 SS-0.08 hrs & & \\
\hline 44 & Clarify Feed From Dissolver & $2.44 \mathrm{hrs}$ & 40 SS & & \\
\hline 45 & Transfer Liquids to Clanifted Liquid Tank & $2.44 \mathrm{hrs}$ & 4ASS & & \\
\hline 47 & Flush Solids Cake With Water (60 liters) & $0.08 \mathrm{hrs}$ & 46 & & \\
\hline 48 & Homogenize Solids Cake and Water & $0.08 \mathrm{hrs}$ & 47 & & \\
\hline 49 & Recentrifuge Hornogenized Slumy & $0.17 \mathrm{hrs}$ & 48 & & \\
\hline 50 & Transter Liquids to Clanified Liquid Tank & $0.17 \mathrm{hrs}$ & 49SS & & \\
\hline 52 & Homogenize Solids Cake and Water & $0.08 \mathrm{nrs}$ & 51 & & \\
\hline 53 & Transfer Solution to Leaching Tank & $0.08 \mathrm{hrs}$ & 52 & & \\
\hline 54 & Prepare Centrifuge for more feed & $0.08 \mathrm{hrs}$ & 53 & & \\
\hline \multicolumn{5}{|l|}{55} & \\
\hline 56 & Leach Rinsed Dissolver Solids (Batch 1) & $4.58 \mathrm{hrs}$ & & Leaching Tank & \\
\hline 57 & Receive Cenlrifuged Dissolver Slumy & $0.08 \mathrm{hrs}$ & 53SS & & \\
\hline 58 & Add Leaching Reagents & $0.5 \mathrm{hrs}$ & 57 & & \\
\hline 59 & Homogenize Slumy to Aid Leaching & $4 \mathrm{hrs}$ & 58 & & \\
\hline \multicolumn{5}{|l|}{60} & \\
\hline 61 & Traṇsfer Leached Dissolver Slurry to Centrifugo (Batch 1) & $0.25 \mathrm{hrs}$ & & Leaching Tank & \\
\hline \multicolumn{5}{|l|}{63} & \\
\hline 64 & Centrifuge Leached Dissolver Slurry (Batch 1 ) & $1.1 \mathrm{hrs}$ & & Centrifuge & \\
\hline 65 & Start Centrifuge & $0.08 \mathrm{hrs}$ & 62SS-0.08 hrs & & \\
\hline 66 & Clarify Feed From Leaching Tank & $0.25 \mathrm{hrs}$ & $62 S$ & & \\
\hline 67 & Transfer Liquids to Clanifred Liquid Tank & $0.25 \mathrm{hrs}$ & $\widehat{66 \$ S}$ & & \\
\hline 68 & Stop Centrifuge When Clarification Complete & $0.08 \mathrm{brs}$ & 66 & & \\
\hline 69 & Flush Solids Cake With Water (60 liters) & $0.08 \mathrm{hrs}$ & 68 & & \\
\hline 70 & Homogenize Solids Cake and Water & $0.08 \mathrm{hrs}$ & 69 & & \\
\hline 71 & Recentrifuge Homogenized Slumy & $0.17 \mathrm{hrs}$ & 70 & & \\
\hline 72 & Transfer Liquids to Clanfifed Liquid Tank & 0.17 hrs & $71 \$ \$$ & & \\
\hline 73 & Fiush Solids Cake With Water (75 liters) & $0.1 \mathrm{hrs}$ & 72 & & \\
\hline 74 & Homogenize Solids Cake and Water & $0.08 \mathrm{hrs}$ & 73 & & \\
\hline 75 & Transter Solution to Solids Reception Tank & $0.08 \mathrm{hrs}$ & 74 & & \\
\hline 76 & Prepare Centrifuge for more feed & $0.08 \mathrm{hrs}$ & 75 & & \\
\hline \multicolumn{5}{|l|}{77} & \\
\hline 78 & Store Clarified Liquid (Batch 1) & 8.81 hrs & & Clarified Liquid Tank & \\
\hline 79 & Receive Clarified Dissolver Liquids From Centrifuge & $2.44 \mathrm{hrs}$ & $45 S S$ & & \\
\hline 80 & Receive Wash Liquids From Centrifuge & $0.17 \mathrm{hrs}$ & $50 \mathrm{sS}$ & & \\
\hline 81 & Receive Clarified Leached Dissolver Slurry Liquids From Centrifuge & $0.25 \mathrm{hrs}$ & $67 S S$ & & \\
\hline 82 & Receive Wash Liquids From Centrifuge & $0.17 \mathrm{hrs}$ & $72 S S$ & & \\
\hline
\end{tabular}


Figure D-8 -- KW2 Process Steps for 3 Adj. Tanks \& 2 Dissolvers Aiternative (cont.)

\begin{tabular}{|c|c|c|c|c|c|}
\hline 10 & Task Name & Duration & Predecessors & Resource Names & 1 \\
\hline 83 & Transfer Clanified Liquid to Cartridge Filter & 0.37 hrs & $82 \mathrm{Fs}+0.17 \mathrm{hrs}$ & & \\
\hline 84 & & & & & \\
\hline 85 & Filter Clarified Liquid (Batch 1) & $0.97 \mathrm{hrs}$ & & Cartridge Filter & \\
\hline 86 & Process Clarified Liquid Through Cartridge Filter & 0.37 hrs & 8355 & & \\
\hline 87 & Transfer Fittered Liquid to Adjustment Tank & $0,37 \mathrm{hrs}$ & 8655 & . & \\
\hline 88 & Rinse Cartridge Filter & $0.5 \mathrm{hrs}$ & .87 & & \\
\hline 89 & Changeout Cartridge Filter & ohrs & 88FS +0.1 hrs & & \\
\hline 90 & Send Used Gartridge Filter to Final Conditioning & $a \mathrm{hrs}$ & 89 & & \\
\hline 91 & & & & & \\
\hline 92 & Adjust Fijtered Liquid (Batch 1) & $51.12 \mathrm{hrs}$ & & Adjustment Tank 1 & \\
\hline 93 & Receive and Store Filtered Liquid & $0,87 \mathrm{hrs}$ & $875 S$ & & \\
\hline 94 & Sample and Wait For Results & $48 \mathrm{hrs}$ & 93 & & \\
\hline 95 & Add Adjustment Reagents ( 1279 liters) & $1 \mathrm{hr}$ & 94 & & \\
\hline 96 & Homogenize Adjusted Liquid & $0.25 \mathrm{hrs}$ & 95 & & \\
\hline 97 & Transfer Adjusted Liquid to Neutralization Tank & $1 \mathrm{hr}$ & 96 & & \\
\hline 98 & & & & & \\
\hline 99 & Neutralize Adjusted Liquid (Batch $\eta$ ) & $5.58 \mathrm{hrs}$ & & Neutralization Tank & \\
\hline 100 & Receive and Store Adjusted Liquid & $1.08 \mathrm{hrs}$ & 9758 & & \\
\hline 101 & Add Neutralization Reagents & $1 \mathrm{hr}$ & 100 & & \\
\hline 102 & Homogenize and Cool Neutralized Slurry & $2 \mathrm{hrs}$ & 101 & & \\
\hline 103 & Sample Slury to Gonfirm TWRS Acceptability & Ohrs & 102 & & \\
\hline 104 & Transfer Neutralized Sluny to Transport System & $1.5 \mathrm{hrs}$ & 103 & 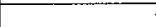 & \\
\hline 105 & & & & & \\
\hline 106 & Transpert Neutralized Slurry to TWRS (Batch 1) & $9.5 \mathrm{hrs}$ & & TWRS Transport & \\
\hline 107 & Receive and Load Neutralized slury & $1.5 \mathrm{hrs}$ & $104 S S$ & & \\
\hline 108 & Transport Slumy to Tank Farms & $8 \mathrm{hrs}$ & 107 & & \\
\hline 109 & & & & & \\
\hline 110 & END BATCH 1 & o hrs & & & \\
\hline 111 & This marks the end of batch 1 & O hrs & 108 & & \\
\hline$\$ 12$ & & & & & \\
\hline 113 & & & & & \\
\hline 114 & Stare Process Foed (Batch 2) & 2.67 hrs & & Lag Storage Tank & \\
\hline 115 & Configure Recelving Station & $0.5 \mathrm{hrs}$ & $7 S S+18$ hrs & & \\
\hline 116 & Receive Sludge & $1 \mathrm{hr}$ & 115 & & \\
\hline 117 & Homogenize Feed & $0.17 \mathrm{hrs}$ & 116 & & \\
\hline 118 & Feed Screening Process & $1 \mathrm{hr}$ & 117 & & \\
\hline 119 & . & & & & \\
\hline 120 & Screen Process Feed (Batch 2 ) & $2 \mathrm{hrs}$ & & Screening System & \\
\hline 121 & Screen Feed & thr & 118SS & & \\
\hline 122 & Run Flush Water As Needed & $1 \mathrm{hr}$ & $118 S S$ & & \\
\hline 123 & Store and homogenize screened particles & $2 \mathrm{hs}$ & $118 \mathrm{SS}$ & Interim Holding Tank & \\
\hline
\end{tabular}




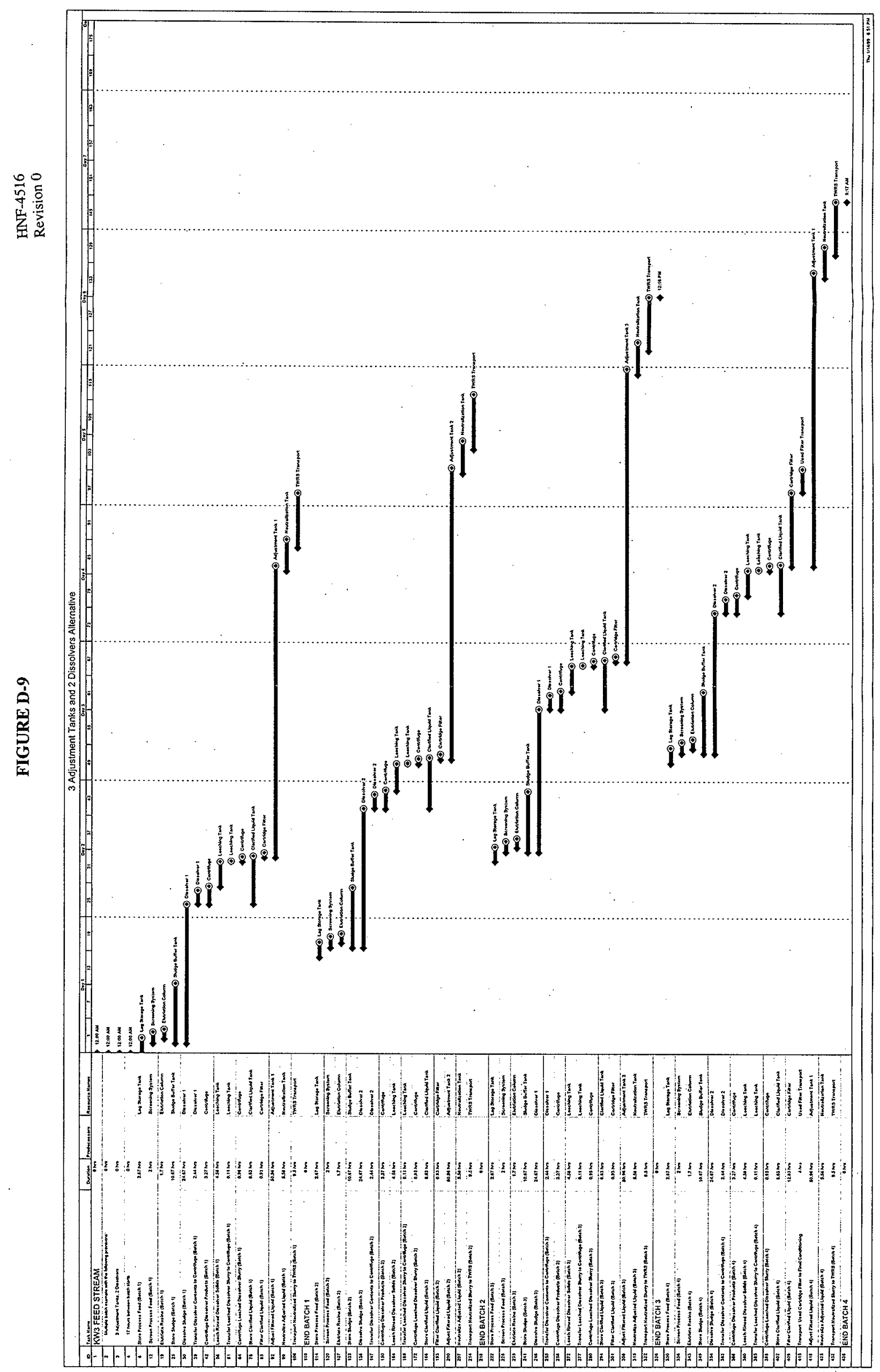


Figure D-10 - KW3 Process Steps for 3 Adj. Tanks \& 2 Dissolvers Alternative

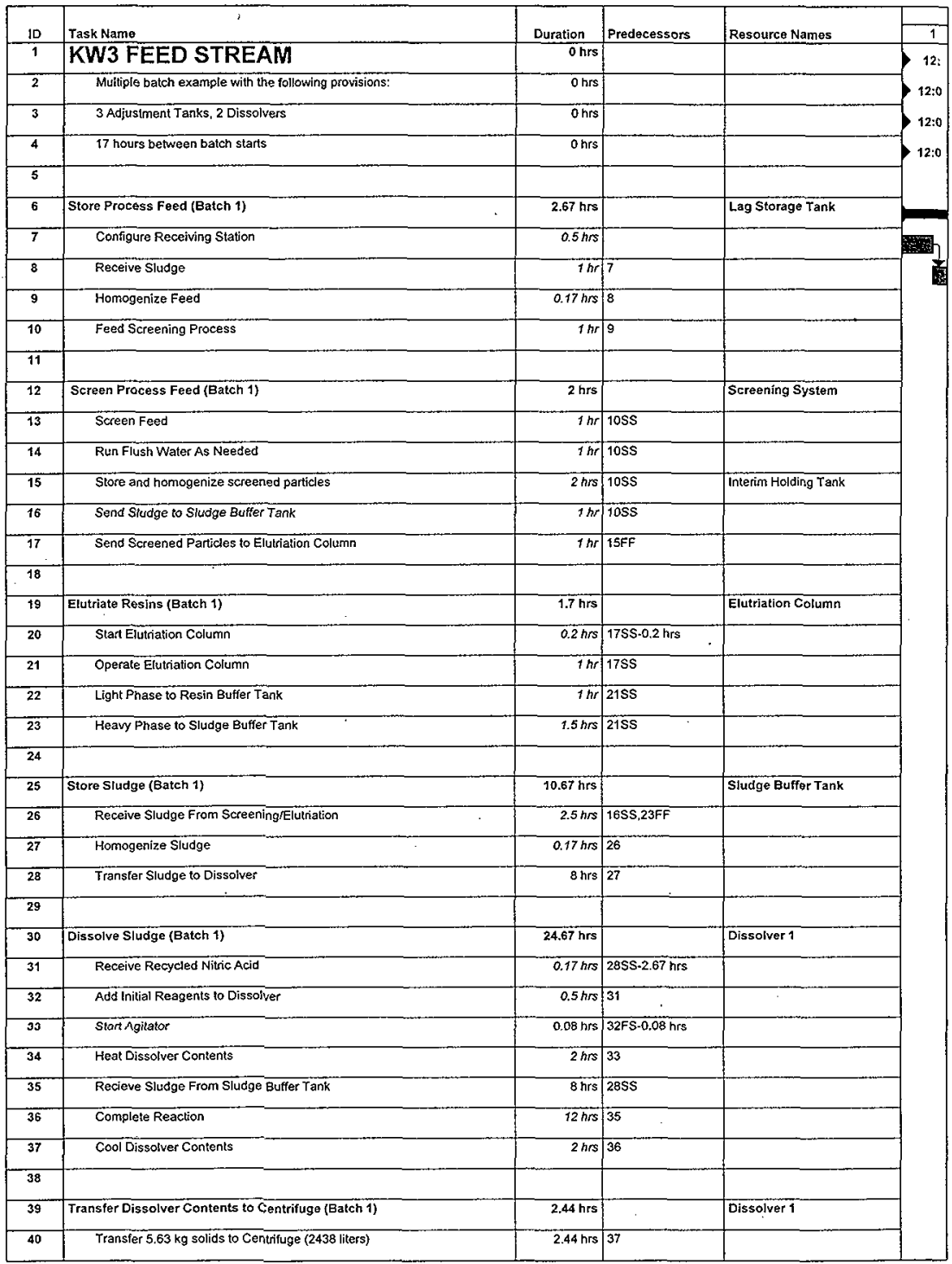


Figure D-10 -- KW3 Process Steps for 3 Adj. Tanks \& 2 Dissolvers Alternative (cont.)

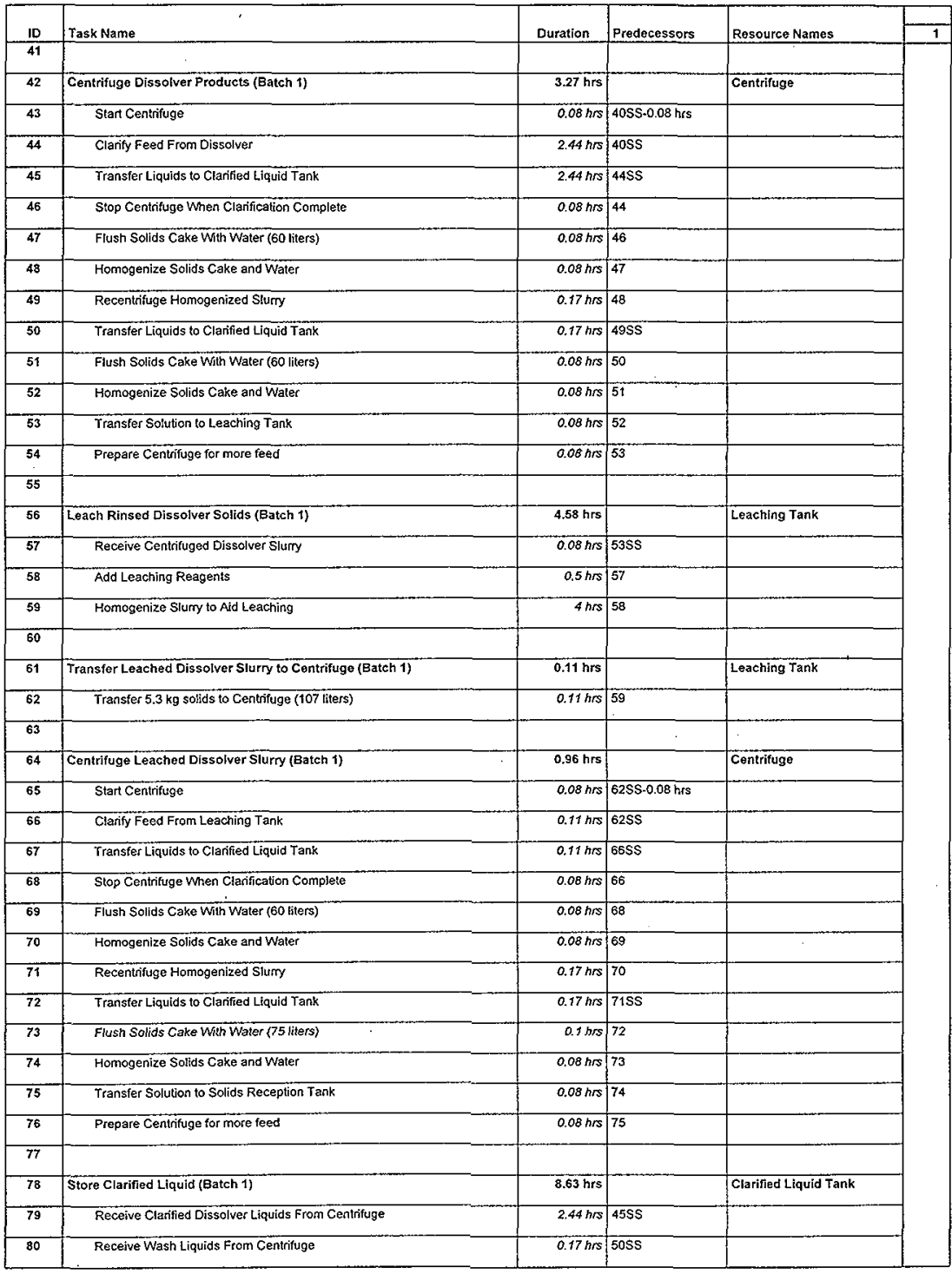


Figure D-10 - KW3 Process Steps for 3 Adj. Tanks \& 2 Dissolvers Alternative (cont.)

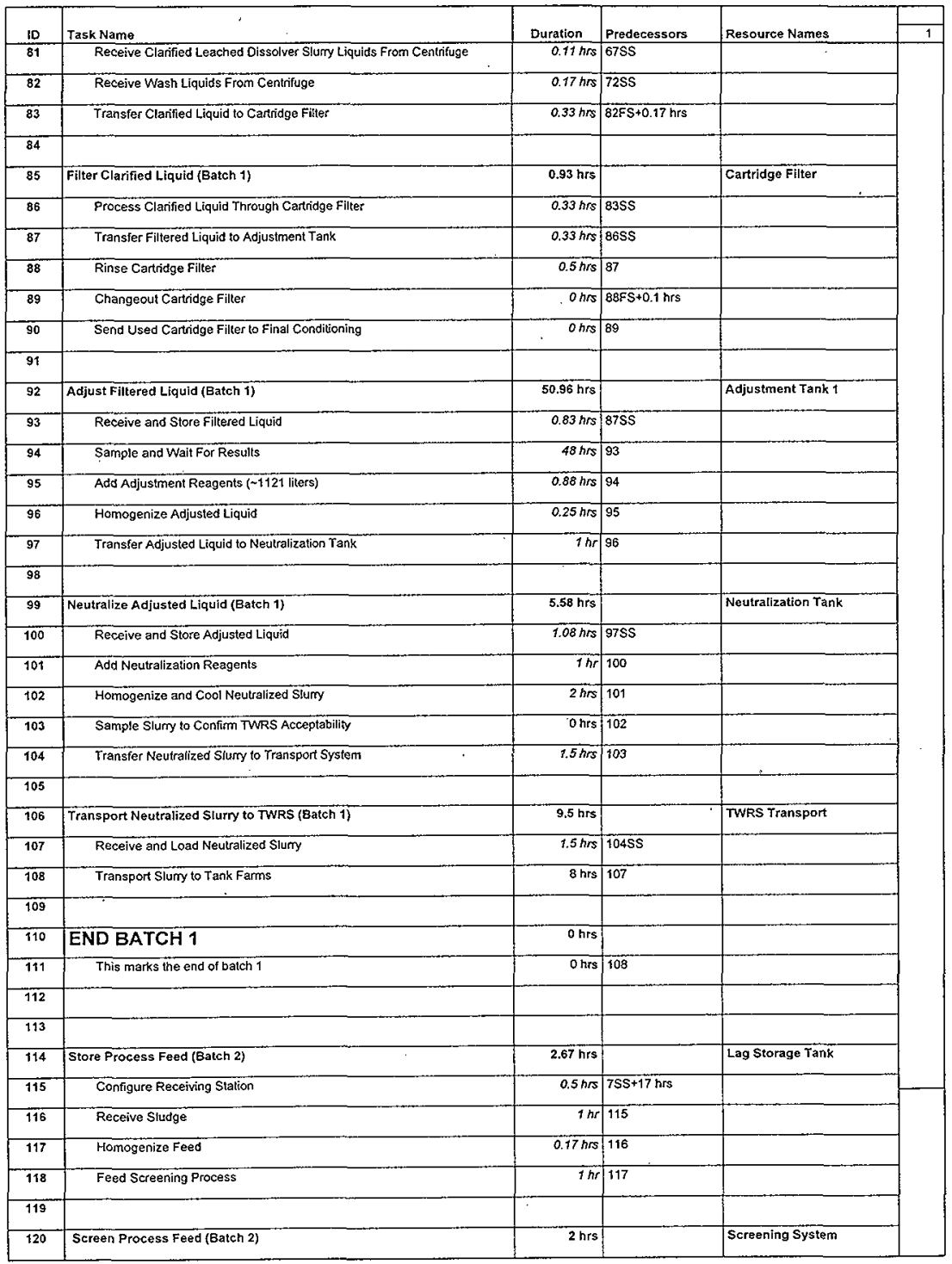


HNE-45I6

Revision 0

Figure D-11- Excel Spreadsheet Calculation Display

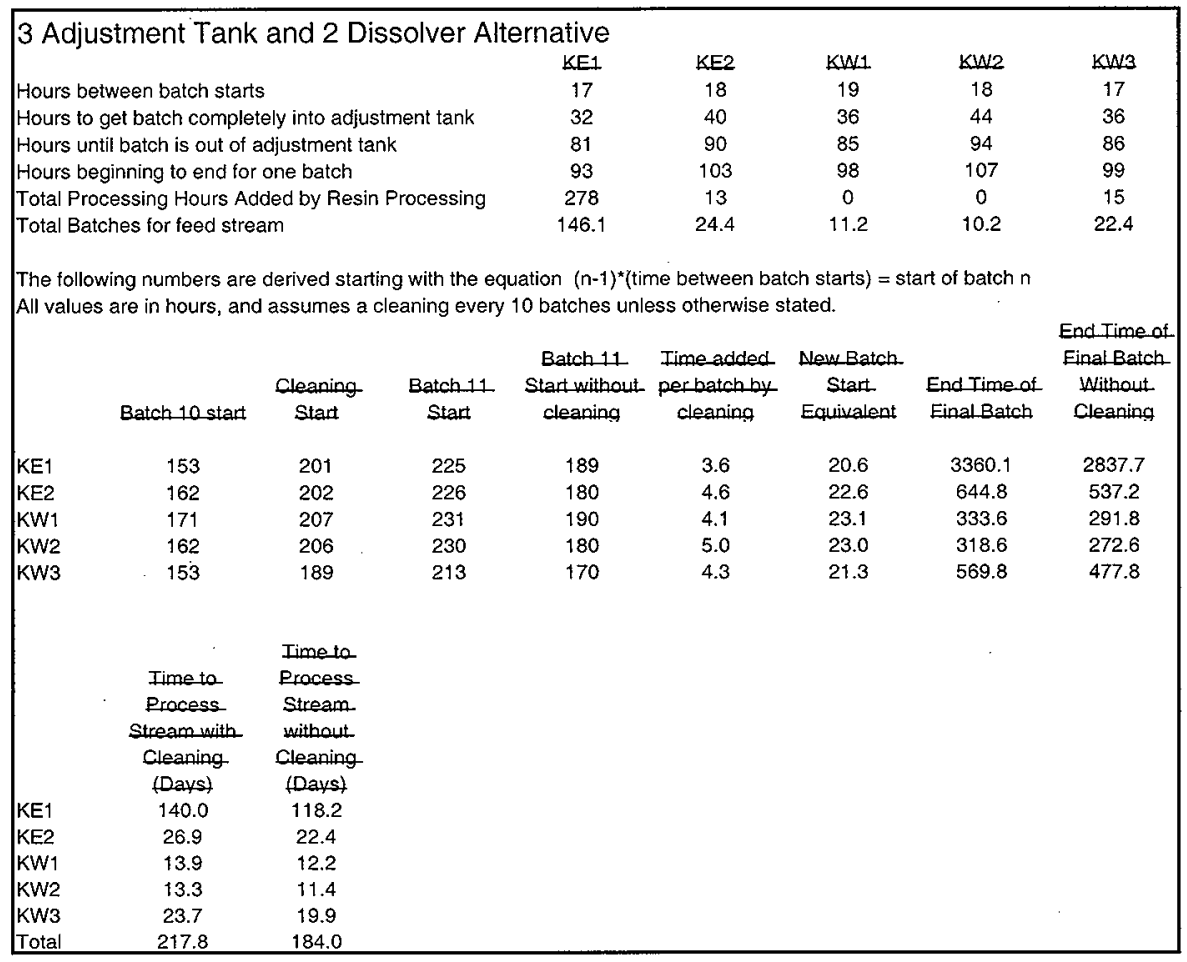


HNF-4516

Revision 0

APPENDIX E

SUPPORT INFORMATION AND CALCULATION RESULTS FOR GROUTING 
The summary process steps from the Microsoft Project model for grouting treated solids were shown previously in Figure 5-1. Figure 5-1 was directly used to estimate the time required for grouting treating solids. The detailed process steps supporting Figure 5-1 can be found in Figure E-1. There were no other calculations performed for this piece of the process. 
Figure E-1 -- Detailed Process Steps for Grouting Treated Solids

\begin{tabular}{|c|c|c|c|c|c|}
\hline \multirow[b]{2}{*}{10} & \multirow[b]{2}{*}{ Task Name } & \multirow[b]{2}{*}{ Duration } & \multirow[b]{2}{*}{ Predecessors } & \multirow[b]{2}{*}{ Resource Names } & \multirow[b]{2}{*}{1} \\
\hline & & & & & \\
\hline 1 & Grout Treated Solids & Ohrs & & & $12: 00$ \\
\hline 2 & Assume 3 Adjustment Tanks Available & 0 hrs & & & $12: 00 \mathrm{~A}$ \\
\hline \multicolumn{6}{|l|}{3} \\
\hline 4 & Treat Excess Liquid & ohrs & . & & $12: 00$ \\
\hline 5 & Assume this can be done in 6 equal oatches & onrs & & & $12: 00 \mathrm{~A}$ \\
\hline \multicolumn{6}{|l|}{6} \\
\hline 7 & Settle Leached/Flushed slurry & 120 hrs & & Solids Reception Tank & \\
\hline 8 & Receive All Slurny Bofore Starting $(52,127$ Liters) & Ohrs & & & 12.0 \\
\hline 9 & Settle Solids in Solids Reception Tank & 5 days & 8 & & \\
\hline \multicolumn{6}{|l|}{10} \\
\hline 11 & Decant and Transfer Excess Liquid & $101 \mathrm{hrs}$ & & Solids Reception Tank & \\
\hline 12 & Transfer Excess Liquid Batch 1 (6,527 liters) & $1 \mathrm{hr}$ & 9 & & \\
\hline 13 & Transfer Excoss Liquid Batch 2 (5,527 liters $\}$ & $1 \mathrm{he}$ & $12 S S+20$ hes & & \\
\hline 14 & Transfer Excess Liquid Batch 3 (5,527 liters) & $1 \mathrm{hr}$ & $13 \mathrm{SS}+20 \mathrm{hrs}$ & & \\
\hline 15 & Transfer Excess Liquid Batch $4(5,527$ liters $)$ & $\mathrm{inr}$ & $14 \mathrm{SS}+20 \mathrm{hrs}$ & & \\
\hline 16 & Transfer Excess Liquid Batch 5 ( 5,527 liters $)$ & inr & $15 S \mathrm{~S}+20 \mathrm{hls}$ & . & \\
\hline 17 & Transfer Excess Liquid Batch $6\{5,527$ liters $\}$ & $1 \mathrm{hr}$ & $16 \mathrm{SS}+20 \mathrm{hrs}$ & & \\
\hline \multicolumn{6}{|l|}{18} \\
\hline 19 & Store Excess Liquid (Batch 1) & $1.62 \mathrm{hrs}$ & & Clarified Liquid Tank & \\
\hline 20 & Receive Excess Liquid (5,527 liters) & $1 \mathrm{hr}$ & $12 \mathrm{SS}$ & & \\
\hline 21 & Transfer Excess Liquid to Cartridge Filter & $0.62 \mathrm{hrs}$ & 20 & & \\
\hline \multicolumn{6}{|l|}{22} \\
\hline 23 & Filter Excess Liquid (Batch 1) & $0.62 \mathrm{hrs}$ & & Cartridge Filter & \\
\hline 24 & Process Excess Liquid Through Cartridge Filter & $0.62 \mathrm{hrs}$ & 2155 & & \\
\hline 25 & Transfer Filtered Liquid to Adjustment Tank & $0.62 \mathrm{hrs}$ & $24 S S$ & . & \\
\hline 26 & Rinse Cartridgo Fitler & o hrs & 25 & & \\
\hline 27 & Changeout Cartridge Fitter & O hets & 26 & & \\
\hline 28 & Send Used Cartridge Filler to Final Conditioning & onts & 27 & & \\
\hline \multicolumn{6}{|l|}{29} \\
\hline 30 & Adjust Filtered Liquid (Batch 1) & $49.87 \mathrm{hrs}$ & & Adjustment Tank 1 & \\
\hline 31 & Receive and Store Filtered Liquid & $0.62 \mathrm{hrs}$ & $255 S$ & & \\
\hline 32 & Sample and Waik For Results & 48 hrs & 31 & & \\
\hline 33 & Add Adjustment Reagents (< 1 literbatch) & Ohrs & 32 & & \\
\hline 34 & Homogenize Adjusted Liquid & $0.25 \mathrm{hrs}$ & 33 & & \\
\hline 35 & Transfer Adjusted Liquid to Neutralization Tank & $1 \mathrm{hr}$ & 34 & & \\
\hline \multicolumn{6}{|l|}{36} \\
\hline 37 & Neutralize Adjusted Liquid (Batch $t$ ) & $3.33 \mathrm{hrs}$ & & Neutralization Tank & \\
\hline 38 & Receive and Store Adjusled Liquid & $1.08 \mathrm{hrs}$ & $35 s \mathrm{~s}$ & & \\
\hline 39 & Add Neutralization Reagents $(\sim 16$ litersioatch $)$ & $0.25 \mathrm{hrs}$ & 38 & & \\
\hline 40 & Homogenize and Cool Neutralized Slurry & $0.5 \mathrm{hrs}$ & 39 & & \\
\hline 41 & Samplo Slurry to Confirm TWRS Acceplability & Ohrs & 40 & & \\
\hline 42 & Transfer Neutralized Slurny to Transport System & $1.5 \mathrm{hrs}$ & 41 & & \\
\hline
\end{tabular}


Figure E-1 -. Detailed Process Steps for Grouting Treated Solids (cont.)

\begin{tabular}{|c|c|c|c|c|c|}
\hline 10 & Task Name & Duration & Predecessors & Resource Names & 1 \\
\hline \multicolumn{5}{|l|}{43} & \\
\hline 44 & Transport Neutralized Slurry to TWRS (Batch 1) & $9.5 \mathrm{hrs}$ & & TWRS Transport & \\
\hline 45 & Receive and Load Neutralized Slurry & $1.5 \mathrm{hrs}$ & $42 \mathrm{SS}$ & & \\
\hline 46 & Transport Sturny to Tank Fams & $8 \mathrm{hrs}$ & 45 & & \\
\hline \multicolumn{5}{|l|}{47} & \\
\hline 48 & Store Excess Liquid (Batch 2) & $1.62 \mathrm{hrs}$ & & Clarifted Llquid Tank & \\
\hline 49 & Receive Excess Liquid $(5,527$ hilers $)$. & $1 \mathrm{hr}$ & $13 \$ s$ & & \\
\hline 50 & Transfer Excess Liquid to Cartridge Filter & $0.62 \mathrm{hrs}$ & 49 & & \\
\hline \multicolumn{5}{|l|}{51} & \\
\hline 52 & Filter Excess Liquid (Batch 2) & 0.62 his & & Cartridge Filter & \\
\hline 53 & Process Excess Liquid Through Cartidge Filter & 0.62 hrs & $50 S S$ & & \\
\hline 54 & Transfer Filtered Liquió to Adjus!ment Tank & $0.62 \mathrm{hrs}$ & $53 S S$ & & \\
\hline 55 & Rinse Cartridge Filter & ohrs & 54 & & \\
\hline 56 & Changeoul Cartidge Filter & O hrs & 55 & & \\
\hline 67 & Send Used Cartridge Filler to Final Conditioning & o hrs & 56 & & \\
\hline \multicolumn{5}{|l|}{58} & \\
\hline 59 & Adjust Filtered Liquid (Batch 2) & $49.87 \mathrm{hrs}$ & & Adjustment Tank 2 & \\
\hline 60 & Receive and Store Filtered Liquio & $0.62 \mathrm{hrs}$ & $54 S S$ & & \\
\hline 61 & Sample and Wait For Results & 48 hrs & 60 & & \\
\hline 62 & Add Adjustment Reagents ( $<$ i liter/batch) & onrs & 61 & & \\
\hline 63 & Homogenize Adjusted Liquid & $0.25 \mathrm{hrs}$ & 62 & & \\
\hline 64 & Transfer Adjusted Liquid to Neuttalization Tank & $1 \mathrm{hr}$ & 63 & & \\
\hline 65 & . & & & & \\
\hline 66 & Neutralize Adjusted Liquid (Batch 2) & $3.33 \mathrm{hrs}$ & & Neutralization Tank & \\
\hline 67 & Receive and Store Adjusted Liquid & $1.08 \mathrm{hrs}$ & $64 \$ S$ & & \\
\hline 68 & Add Neutralization Reagents ( 16 litersioatch) & $0.25 \mathrm{hrs}$ & 67 & & \\
\hline 69 & Homogenize and Cool Neutralized Slurry & $0.5 \mathrm{hrs}$ & 68 & & \\
\hline 70 & Sample Slurry to Confirm TWRS Acceptability & Onrs & 69 & & \\
\hline 71 & Transfer Neutralized Slurry to Transport System & $1.5 \mathrm{hrs}$ & 70 & & \\
\hline \multicolumn{5}{|l|}{72} & \\
\hline 73 & Transport Neutralized Slurry to TWRS (Batch 2) & 9.5 hrs & & TWRS Transport & \\
\hline 74 & Receive and Load Neutratized Slurry & $1.5 \mathrm{hrs}$ & $71 S S$ & & \\
\hline 75 & Transport Siumy to Tank Farms & $8 \mathrm{hrs}$ & 74 & & \\
\hline \multicolumn{5}{|l|}{76} & \\
\hline 77 & Store Excess Liquid (Batch 3) & $1.62 \mathrm{hrs}$ & & Clarified Liquid Tank & \\
\hline 78 & Receive Excess Liquid (5.527 liters) & $1 \mathrm{hr}$ & $14 \$ \$$ & & \\
\hline 79 & Transfer Excess Liquid to Cantridge Fitter & $0.62 \mathrm{hrs}$ & 78 & & \\
\hline \multicolumn{5}{|l|}{80} & \\
\hline 81 & Filter Excess Liquid (8atch 3) & $0.62 \mathrm{hrs}$ & & Cartridge Filter & \\
\hline 82 & Process Excess Liquid Through Cartridge Filter & $0.62 \mathrm{hrs}$ & 795 & & \\
\hline 83 & Transfer Filtered Lqquid to Adjustment Tank & 0.62 hrs & $82 S S$ & & \\
\hline 84 & Rinse Cartridge Fitter & $0 \mathrm{hrs}$ & 83 & & \\
\hline
\end{tabular}


Figure E-1 -- Detailed Process Steps for Grouting Treated Solids (cont.)

\begin{tabular}{|c|c|c|c|c|c|}
\hline ID & Task Name & Duration & Predecessors & Resourco Names & 4 \\
\hline 85 & Changeout Cartridge Filier & Ohrs & 84 & & \\
\hline 86 & Send Used Cartridge Fither to Final Conditioning & ohrs & 85 & & \\
\hline \multicolumn{5}{|l|}{87} & \\
\hline 88 & Adjust Filtered Liquid (Batch 3) & $49.87 \mathrm{hrs}$ & & Adjustment Tank 3 & \\
\hline 89 & Receive and Store Fittered Liquid & 0.62 hrs & $\overline{83 S S}$ & & \\
\hline 90 & Sample and Wail For Results & $48 \mathrm{hrs}$ & 89 & & \\
\hline $9 t$ & Add Adjustment Reagents ( $<1$ liter/batch) & $0 \mathrm{hrs}$ & 90 & & \\
\hline 92 & Homogenize Adjusled Liquid & $0.25 \mathrm{hrs}$ & 91 & & \\
\hline 93 & Transfer Adjusted Liquid to Neutralization Tank & $1 \mathrm{hr}$ & 92 & & \\
\hline \multicolumn{5}{|l|}{94} & \\
\hline 95 & Neutralize Adjusted Liquid (Batch 3) & 3.33 hrs & & Neutralization Tank & \\
\hline 96 & Receive and Store Adjusted Liquid & $1.08 \mathrm{hrs}$ & 9355 & & \\
\hline 97 & Add Neutralization Reagents ( 16 litersibatch) & 0.25 hrs & 5 & & \\
\hline 98 & Homogenize and Cool Neutralized Stumy & $0.5 \mathrm{hrs}$ & 97 & & \\
\hline 99 & Sample Slurry to Confirm TWRS Acceptability & $0 \mathrm{hrs}$ & 98 & & \\
\hline 100 & Transfer Neutralized Slurny to Transport System & $1.5 \mathrm{hrs}$ & 99 & & \\
\hline \multicolumn{5}{|l|}{101} & \\
\hline 102 & Transport Neutralized Slurry to TWRS (Batch 3) & $9.5 \mathrm{hrs}$ & & TWRS Transport & \\
\hline 103 & Receive and Load Neutralized Slurny & 1.5 hrs & $100 \mathrm{ss}$ & & \\
\hline 104 & Transport Slurry to Tank Farms & $8 \mathrm{hrs}$ & 103 & & \\
\hline \multicolumn{5}{|l|}{105} & \\
\hline 106 & Store Excess Liquid (Batch 4) & $1.62 \mathrm{hrs}$ & & Clarifted Liquid Tank & \\
\hline 107 & Receive Excess Liquid (5,527 liters) & $1 \mathrm{hr}$ & $15 S S$ & & \\
\hline 108 & Transfer Excess Liquid to Cartridge Filter & $0.62 \mathrm{hrs}$ & 107 & & \\
\hline 109 & . & & & & \\
\hline 110 & Filter Excess Liquid (Batch 4) & 0.62 hrs & & Cartridge Filter & \\
\hline 111 & Process Excess Liquid Through Cartidge Fitter & 0.62 hrs & 108Ss & & \\
\hline 112 & Transter Fittereo Liquid to Adjustment Tank & $0.62 \mathrm{hrs}$ & $111 \mathrm{SS}$ & & \\
\hline 113 & Rinse Cartridge Filter & Ohrs & 112 & & \\
\hline 114 & Changeout Carttidge Flter & 0 hrs & 113 & & \\
\hline 115 & Send Used Cartridge Filter to Final Conditioning & o hrs & 114 & & \\
\hline \multicolumn{5}{|l|}{116} & \\
\hline 117 & Adjust Filtered Liquid (Batch 4) & 49.87 hrs & & Adjustment Tank 1 & \\
\hline 118 & Receive and Store Filtered Liquid & 0.62 rrs & $1125 s$ & & \\
\hline 119 & Sample and Wait For Results & 48 hrs & 118 & & \\
\hline 120 & Add Adjustment Reagents (< I literibatch) & $\overline{0 \text { hrs }}$ & 119 & & \\
\hline 121 & Homogenize Adjusted Liquid & 0.25 his & 120 & & \\
\hline 122 & Transfer Adjusted Liquid to Nevtralization Tank & $1 \mathrm{hr}$ & 121 & & \\
\hline \multicolumn{5}{|l|}{123} & \\
\hline 124 & Neutralize Adjusted Liquid (Batch 4) & $3.33 \mathrm{hrs}$ & & Noutralization Tank & \\
\hline 125 & Receive and Store Adjusted Liquid & $1.08 \mathrm{hrs}$ & $122 S S$ & & \\
\hline 126 & Add Neutralization Reagents ( -16 liters/oatch) & $0.25 \mathrm{hrs}$ & 125 & & \\
\hline
\end{tabular}


Figure E-1 -- Detailed Process Steps for Grouting Treated Solids (cont.)

\begin{tabular}{|c|c|c|c|c|c|}
\hline ID & Task Name & Duration & Predecessors & Resource Names & 1 \\
\hline 127 & Homogenize and Cool Neutralized Slurn & $0.5 \overline{h r s}$ & 126 & & \\
\hline 128 & Sample Siurry to Contirm TWRS Acceplability & 0 hrs & 127 & & \\
\hline 129 & Transfer Neutralized Slurry to Transport System & $1.5 \mathrm{hrs}$ & 128 & & \\
\hline \multicolumn{5}{|l|}{130} & \\
\hline 131 & Transport Neutralized Slumy to TWRS (8atch 4) & $9.5 \mathrm{hrs}$ & & TWRS Transport & \\
\hline 132 & Receive and Load Neutralized Slurry & $1.5 \mathrm{hrs}$ & 129SS & & \\
\hline 133 & Transport Slurry to Tank Farms & $8 \mathrm{hrs}$ & 132 & & \\
\hline \multicolumn{5}{|l|}{134} & \\
\hline 135 & Store Excess Liquid (Batch 5) & $1.62 \mathrm{hrs}$ & & Clarifled Liquid Tank & \\
\hline 136 & Receive Excess Liquid (5,527 liters) & $1 \mathrm{ht}$ & $16 S S$ & & \\
\hline 137 & Transfer Excess Liquid to Cartridge Filter & $0.62 \mathrm{hrs}$ & 136 & & \\
\hline \multicolumn{5}{|l|}{138} & \\
\hline 139 & Filter Excess Liquid $\{$ Batch 5$\}$ & 0.62 his & & Cartridge Filter & \\
\hline 140 & Process Excess Liquid Through Cartridge Filter & $0.62 \mathrm{hrs}$ & $137 S S$ & & \\
\hline 141 & Transfer Fittered Liquid to Adjustment Tank & $0.62 \mathrm{hrs}$ & $140 \mathrm{SS}$ & & \\
\hline 142 & Rinse Cartridge Fitter & o hrs & 141 & & \\
\hline 143 & Changeout Cartidge Filter & Ohrs & 142 & & \\
\hline 144 & Send Used Cartridge Filter to Final Conditioning & $0 \overline{\mathrm{hrs}}$ & $\overline{143}$ & & \\
\hline \multicolumn{5}{|l|}{145} & \\
\hline 146 & Adjust Filtered Liqutd (Batch 5) & $49.87 \mathrm{hrs}$ & & Adjustment Tank 2 & \\
\hline 147 & Receive and Store Filtered Liquid & $0.62 \mathrm{hrs}$ & $141 S S$ & & \\
\hline 148 & Sample and Wait For Results & $48 \overline{h r s}$ & 147 & & \\
\hline 149 & Add Adjustment Reagenls ( $<$ i liter/balch) & O hrs & 148 & & \\
\hline 150 & Homogenize Adjusted Liquid & $0.25 \mathrm{hrs}$ & 149 & & \\
\hline 151 & Transier Adjusted Liquid to Neutralization Tank & Thr & 150 & & \\
\hline \multicolumn{5}{|l|}{152} & \\
\hline 153 & Neutralize Adjusted Llquid (Batch 5) & 3.33 hrs & & Neutralization Tank & \\
\hline 154 & Receive and Store Adjusted Liquid & $1.08 \mathrm{hrs}$ & $151 \mathrm{SS}$ & & \\
\hline 155 & Add Neutralization Reagents ( 16 litershatch) & 0.25 his & 154 & & \\
\hline 156 & Homogenize and Cool Néutralized Slurry & $0.5 \mathrm{hrs}$ & 155 & & \\
\hline 157 & Sample Slurry to Confirm TWRS Acceptability & Ohrs & 156 & & \\
\hline 158 & Transfer Neultalized Slury to Transport System & $1.5 \mathrm{hrs}$ & 157 & & \\
\hline \multicolumn{5}{|l|}{159} & \\
\hline 160 & Transport Neutralized Slurry to TWRS (Batch 5) & 9.5 hrs & & TWRS Transport & \\
\hline 161 & Receive and Load Neutralized Slurry & $1.5 \mathrm{hrs}$ & $158 \mathrm{BS}$ & & \\
\hline 162 & Transport Slurry 10 Tank Farms & 8 hrs & 161 & & \\
\hline \multicolumn{5}{|l|}{163} & \\
\hline 164 & Store Excess Liquid (Batch 6) & $1.62 \mathrm{hrs}$ & . & Clarified Liquid Tank & \\
\hline 165 & Receive Excess Liquid (5.527 liters) & $1 \mathrm{hr}$ & $17 S S$ & & \\
\hline 166 & Transfer Excess Liquid to Cartridge Filler & 0.62 has & 165 & & \\
\hline \multicolumn{5}{|l|}{167} & \\
\hline 159 & Filter Excess Liquid (Batch 6) & $0,62 \mathrm{hrs}$ & & Cartridge Filfer & \\
\hline
\end{tabular}


Figure E-1 -- Detailed Process Steps for Grouting Treated Solids (cont.)

\begin{tabular}{|c|c|c|c|c|c|}
\hline ID & Task Name & Duration & Predecessors & Resource Names & 1 \\
\hline 169 & Process Excess Liquid Through Cartridge Fitter & $0.62 \mathrm{hrs}$ & $1665 s$ & & \\
\hline 170 & Transfer Filtered Liquid to Adjustment Tank & $0.62 \mathrm{hrs}$ & 169SS & & \\
\hline 171 & Rinse Cartridge Filter & 0 hrs & 170 & & \\
\hline 172 & Changeout Cartridge Filter & Ohrs & 171 & & \\
\hline 173 & Send Used Cartridge Filter to Final Conditioning & ohrs & 172 & & \\
\hline \multicolumn{6}{|l|}{174} \\
\hline 175 & Adjust Filtered Liquid! (8atch 6) & $49.87 \mathrm{hrs}$ & & Adjustment Tank 3 & \\
\hline 176 & Receive and Store Filtered Liquid & $0.62 \mathrm{hrs}$ & $170 \mathrm{sS}$ & & \\
\hline 177 & Sample and Wait For Results & $48 \mathrm{hrs}$ & 175 & & \\
\hline 178 & Add Adjustment Resgents ( 1 liserioatch) & onrs & 177 & & \\
\hline 179 & Homogenize Aojusted Liquid & $0.25 \mathrm{hrs}$ & 178 & & \\
\hline 180 & Transfer Rdjusted Liquid to Neutralization Tank & $1 \mathrm{hr}$ & 179 & & \\
\hline \multicolumn{6}{|l|}{181} \\
\hline 182 & Neutralize Adjusted Liquid (Batch 6) & $3.33 \mathrm{hrs}$ & & Neutralization Tank & \\
\hline 183 & Receive and Store Adjusted Liquid & $1,08 \mathrm{hrs}$ & $180 S S$ & & \\
\hline 184 & Add Neutralization Reagents ( $\sim 16$ litersibalch) & $0.25 \mathrm{hrs}$ & 183 & & \\
\hline 185 & Homogenize and Cool Neutralized Sturry & $0.5 \mathrm{hrs}$ & 184 & & \\
\hline 186 & Sample Slury to Confirm TWRS Acceptability & $0 \mathrm{hrs}$ & 185 & & \\
\hline 187 & Transfer Neutralized Slurry to Transport System & $1.5 \mathrm{hrs}$ & 186 & & \\
\hline \multicolumn{6}{|l|}{188} \\
\hline 189 & Transport Neutralized Slumy to TWRS (Batch 6) & 9.5 hrs & & TWRS Transport & \\
\hline 190 & Receive and Load Neutralized Slurry & $1.5 \mathrm{hrs}$ & $187 \mathrm{SS}$ & & \\
\hline $19 t$ & Transport Slurry to Tank Farms & 8 hrs & 190 & & \\
\hline 192 & & & & . & \\
\hline \multicolumn{6}{|l|}{193} \\
\hline \multicolumn{6}{|l|}{194} \\
\hline 195 & Grout Slurry & o hrs & & & $12: 00$ \\
\hline 196 & Assume this will done in 6 futl batches, ptus 1 partial & Ohrs & & & $12: 00 \mathrm{~A}$ \\
\hline 197 & Assume 1 Grout Liner position avaitable in Pit & $0 \mathrm{hrs}$ & & & $12: 00$ \\
\hline \multicolumn{6}{|l|}{198} \\
\hline 199 & Prepare Slurry & $58 \mathrm{hrs}$ & & Solids Reception Tank & \\
\hline 200 & Homogenize Remaining Slurry & $8 \mathrm{hrs}$ & $17 \mathrm{FS}+1 \mathrm{hr}$ & & \\
\hline 201 & Sample S!urty and Wait For Rosuits & 2 days & 200 & & \\
\hline 202 & Restart Homogenization System & $2 \mathrm{hrs}$ & 201 & & \\
\hline \multicolumn{6}{|l|}{203} \\
\hline 204 & Transfer Slurry to Grout Liner & $360.67 \mathrm{hrs}$ & & Solids Reception Tank & \\
\hline 205 & Transfer 2,846 liters of slurry to liner 1 & $1 \mathrm{hr}$ & 202 & & \\
\hline 206 & Transfer 2,846 liters of slurry to liner 2 & $1 \mathrm{hr}$ & 225 & & \\
\hline 207 & Transfer 2.846 liters of slurry to liner 3 & i hr & 236 & & \\
\hline 208 & Transfer 2,846 liters of slursy to liner 4 & $1 \mathrm{hr}$ & 247 & & \\
\hline 209 & Transfer 2,846 liters of slurry to liner 5 & $1 \mathrm{hr}$ & 258 & & \\
\hline 210 & Transfer 2,846 liters of slurry to liner 6 & i hr & 269 & & \\
\hline
\end{tabular}


Figure E-1 - Detailed Process Steps for Grouting Treated Solids (cont.)

\begin{tabular}{|c|c|c|c|c|c|}
\hline ID & Task Name & Duration & Predecessors & Resource Names & 1 \\
\hline 291 & Transfer 1,889 titers of slurry to liner 7 & $0.67 \mathrm{~h} t \mathrm{~s}$ & 280 & & \\
\hline \multicolumn{5}{|l|}{212} & \\
\hline 213 & Fill Liner 1 & 56 hrs & & Liner Pit & \\
\hline 214 & Place Empty Liner in Pit & 2 hrs & 201 & & \\
\hline 215 & Receive slurry & $1 \mathrm{ht}$ & $205 S$ & & \\
\hline 216 & Add Grout formers & $1 \mathrm{he}$ & 215 & & \\
\hline 217 & Cure Grout Product in Liner Pil & 2 days & 216 & & \\
\hline 218 & Cap and Seal Grout Liner & $4 \mathrm{hrs}$ & 217 & & \\
\hline \multicolumn{5}{|l|}{219} & \\
\hline 220 & Transport Grout Liner 1 & $12 \mathrm{hrs}$ & & Liner Transport & \\
\hline 221 & Load Grout Liner on Ttansport & $4 \mathrm{hrs}$ & 218 & & \\
\hline 222 & Transfer Filled Grout Liner to EROF & $8 \mathrm{hrs}$ & 221 & & \\
\hline \multicolumn{5}{|l|}{223} & \\
\hline 224 & Fil] Liner 2 & $56 \mathrm{hrs}$ & & Liner Pit & \\
\hline 225 & Place Empty Liner in Pit & 2 hrs & 221 & & \\
\hline 226 & Receive slurry & $1 \mathrm{hr}$ & 2065 & & \\
\hline 227 & Add Grout Fotmers & $1 \mathrm{hr}$ & 226 & & \\
\hline 228 & Cure Grout Product in Liner & 2 days & 227 & & \\
\hline 229 & Cap and Seal Grout Liner & 4 hirs & 228 & & \\
\hline \multicolumn{5}{|l|}{230} & \\
\hline 231 & Transport Grout Liner 2 & $12 \mathrm{hrs}$ & & Liner Transport & \\
\hline 232 & Load Grout Liner on Transport & 4 hrs & 229 & & \\
\hline 233 & Transfer Filed Grout Liner to EROF & 8 hrs & 232 & & \\
\hline \multicolumn{5}{|l|}{234} & \\
\hline 235 & Fill Liner 3 & $56 \mathrm{hrs}$ & & Liner Pit & \\
\hline 236 & Place Empty Liner in Pit & 2 hrs & 232 & & \\
\hline 237 & Receive slurny & $1 \mathrm{hr}$ & $2075 s$ & & \\
\hline 238 & Add Grout Formers & $1 \mathrm{hr}$ & 237 & & \\
\hline 239 & Curo Grout Product in Liner & 2 days & 238 & & \\
\hline 240 & Cap and Seal Grout Line: & $4 \mathrm{hrs}$ & 239 & & \\
\hline \multicolumn{5}{|l|}{241} & \\
\hline 242 & Transpon Grout Liner 3 & $12 \mathrm{hrs}$ & & Liner Transport & \\
\hline 243 & Load Grout Liner on Transport & $4 \mathrm{hrs}$ & 240 & & \\
\hline 244 & Transfer Filled Grout Liner to ERDF & 8 hrs & 243 & & \\
\hline \multicolumn{5}{|l|}{245} & \\
\hline 246 & Fill Liner 4 & $56 \mathrm{hrs}$ & & Liner Pit & \\
\hline 247 & Place Emply Liner in Pit & 2 hrs & 243 & & \\
\hline 248 & Receive slurry & $1 \mathrm{hr}$ & 20855 & & \\
\hline 249 & Ado Grout Formers & $1 \mathrm{hr}$ & 248 & & \\
\hline 250 & Cure Grout Product in Liner & 2 days & 249 & & \\
\hline 251 & Cap and Seal Grout Liner & $4 \mathrm{hrs}$ & 250 & & \\
\hline 252 & & & & & \\
\hline
\end{tabular}


Figure E-1 -- Detailed Process Steps for Grouting Treated Solids (cont.)

\begin{tabular}{|c|c|c|c|c|c|}
\hline ID & Task Name & Duration & Predecessors & Resource Names & 1 \\
\hline 253 & Transport Grout Liner 4 & $12 \mathrm{hrs}$ & & Liner Transport & \\
\hline 254 & Load Grout Liner on Transport & 4 hars & 251 & & \\
\hline 255 & Transfer Filled Grout Liner to ERDF & $8 \mathrm{hrs}$ & 254 & & \\
\hline \multicolumn{6}{|l|}{256} \\
\hline 257 & Fill Liner 5 & $56 \mathrm{hrs}$ & & Liner Pit & \\
\hline 258 & Place Emply Liner in Pit & $2 \mathrm{hts}$ & 254 & & \\
\hline 259 & 'Receive slumy & t hr & 2095s & & \\
\hline 260 & Add Groul Formers & $1 \mathrm{hr}$ & 259 & & \\
\hline 261 & Cure Grout Product in Liner & 2 days & 260 & & \\
\hline 262 & Cap and Seal Grout Liner & $4 \mathrm{hrs}$ & 261 & & \\
\hline \multicolumn{6}{|l|}{263} \\
\hline 264 & Transport Grout Liner 5 & $12 \mathrm{hrs}$ & & LIner Transport & \\
\hline 265 & Load Grout Liner on Transport & $4 \mathrm{hrs}$ & 262 & & \\
\hline 266 & Transfer Filled Grout Liner to EROF & 8 his & 265 & & . \\
\hline \multicolumn{6}{|l|}{267} \\
\hline 268 & Fill Liner 6 & $56 \mathrm{hrs}$ & & Liner Pit & \\
\hline 269 & Piece Empty Liner in Pit & $2 \mathrm{hrs}$ & 265 & & \\
\hline 270 & Receive siurty & $1 \mathrm{hr}$ & $210 S s$ & & \\
\hline 271 & Add Grout Formers & $1 \mathrm{hr}$ & 270 & & \\
\hline 272 & Cure Grout Product in Liner & 2 days & 271 & & \\
\hline 273 & Cap and Seal Grout Liner & 4 hrs & 272 & & \\
\hline \multicolumn{6}{|l|}{274} \\
\hline 275 & Transport Grout Liner 6 & 12 hrs: & & Liner Transport & \\
\hline 276 & Load Grout Lifier on Transport & 4 hrs & 273 & & \\
\hline 277 & Transfer Filled Grout Liner to ERDF & $8 n+s$ & 276 & & \\
\hline \multicolumn{6}{|l|}{278} \\
\hline 279 & Fill Liner 7 & 55.67 hrs & & Liner Pit & \\
\hline 280 & Place Emply Liner in Pit & $2 \mathrm{hrs}$ & 276 & & \\
\hline 281 & Receive slutry & 0.67 hrs & 211SS & & \\
\hline 282 & Add Grout Formers & Thr & 281 & . & \\
\hline 283 & Cure Groul Product in Liner & 2 days & 282 & & \\
\hline 284 & Cap and Seal Grout Linet & $4 \mathrm{hrs}$ & 283 & & \\
\hline \multicolumn{6}{|l|}{285} \\
\hline 286 & Transport Grout Liner 7 & $12 \mathrm{hrs}$ & & Liner Transport & \\
\hline 287 & Load Grout Liner on Transport & $4 \mathrm{hrs}$ & 284 & & \\
\hline 288 & Transfer Finled Grout Liner to ERDF & 8 hrs & 287 & & \\
\hline \multicolumn{6}{|l|}{289} \\
\hline \multicolumn{6}{|l|}{290} \\
\hline 291 & Grout Used Cartridge Filters & o hrs & & & $12: 00 \mathrm{~A}$ \\
\hline 292 & Receive Used Carttioge Filiors & onrs & & & $12: 00 \mathrm{~A}$ \\
\hline 293 & Load Cartridge Filters in Drum & Ohrs & & & $12: 00 \mathrm{~A}$ \\
\hline 294 & Store Fitters in Drums & ohrs & & & $12: 00$ \\
\hline
\end{tabular}

